\title{
A NITROGEN-RICH SEPTAGE-EFFLUENT PLUME IN A GLACIAL AQUIFER, CAPE COD, MASSACHUSETTS, FEBRUARY 1990 THROUGH DECEMBER 1992
}

U.S. GEOLOGICAL SURVEY

Open-File Report 95-290

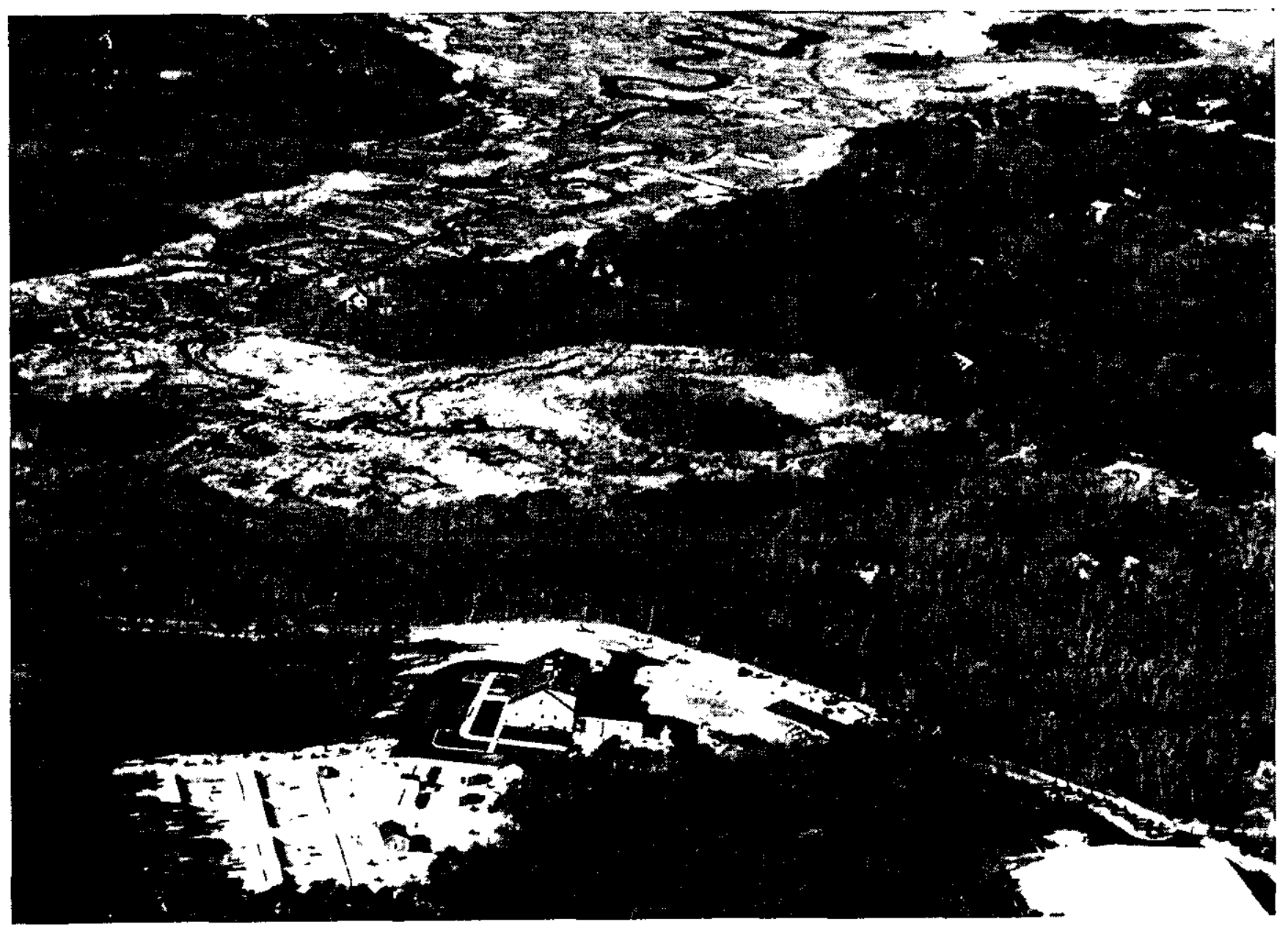

Prepared in cooperation with the

MASSACHUSETTS DEPARTMENT OF ENVIRONMENTAL

PROTECTION, OFFICE OF WATERSHED MANAGEMENT

$$
1995^{\circ}
$$

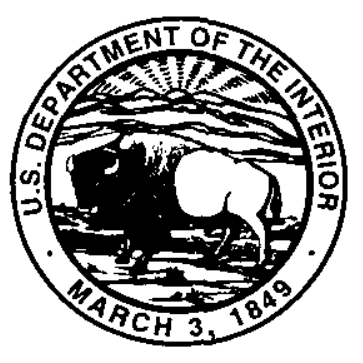




\section{COVER}

Areal view looking westward of the Tri-Town Septage-Treatment Facility (foreground) and Namskaket Marsh and Creek (background).

Photograph taken by Spencer

Kennard, Kelsey-Kennard

Photographers, Inc., Chatham, Massachusetts, and reproduced with permission. 


\section{A NITROGEN-RICH SEPTAGE-EFFLUENT PLUME IN A GLACIAL AQUIFER, CAPE COD, MASSACHUSETTS, FEBRUARY 1990 THROUGH DECEMBER 1992}

By Leslie A. DeSimone and Paul M. Barlow, U.S. Geological Survey; and Brian L. Howes, Woods Hole Oceanographic Institution

U.S. GEOLOGICAL SURVEY

Open-File Report 95-290

Prepared in cooperation with the

MASSACHUSETTS DEPARTMENT OF ENVIRONMENTAL

PROTECTION, OFFICE OF WATERSHED MANAGEMENT

Marlborough, Massachusetts

1995

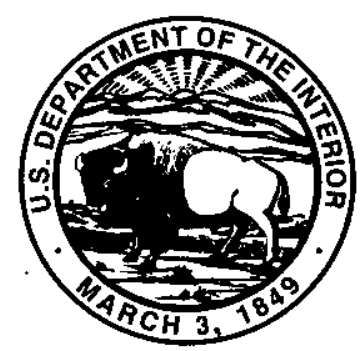




\title{
DEPARTMENT OF THE INTERIOR \\ BRUCE BABBITT, Secretary
}

\author{
U.S. GEOLOGICAL SURVEY \\ Gordon P. Eaton, Director
}

For additional information, write to:

Copies of this report can be purchased from:

Chief, Massachusetts-Rhode Isiand District U.S. Geological Survey Water Resources Division 28 Lord Road, Suite 280 Marlborough, MA 01752
U.S. Geological Survey Earth Science Information Center Open-File Reports Section Box 25286, MS 517

Federal Center

Denver, CO 80225 


\section{CONTENTS}

Abstract

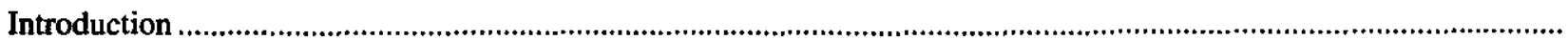

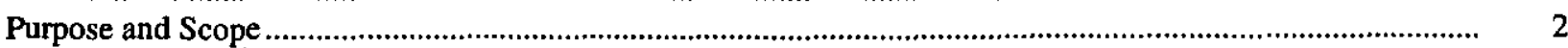

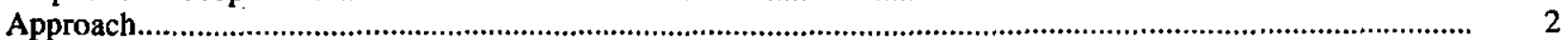

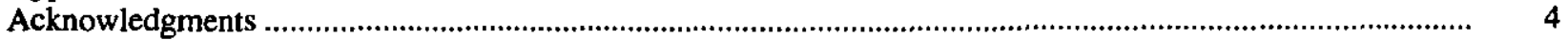

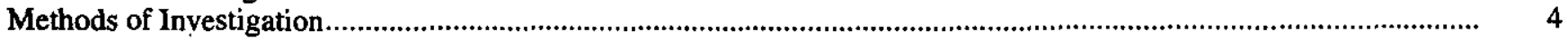

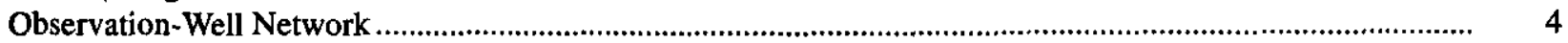

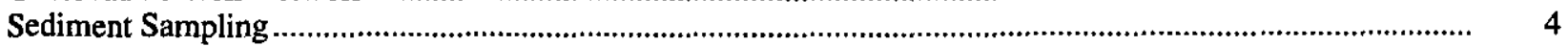

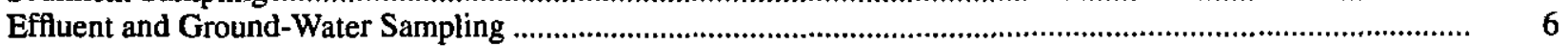

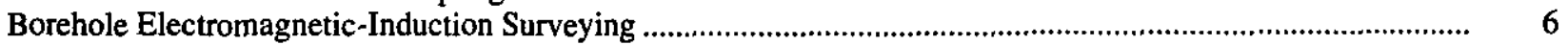

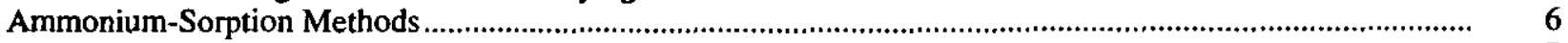

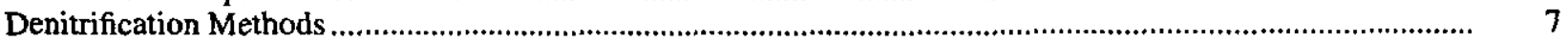

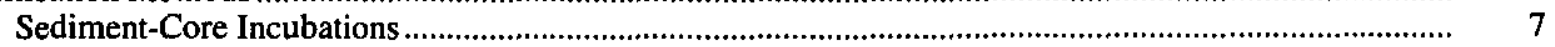

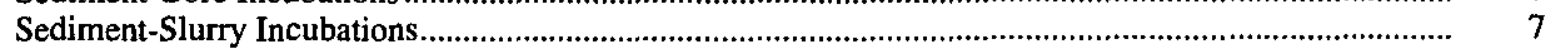

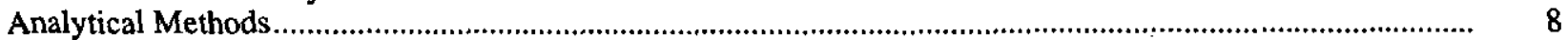

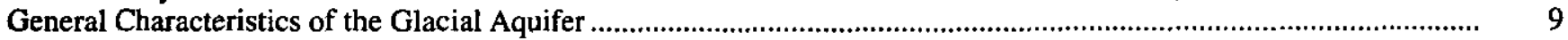

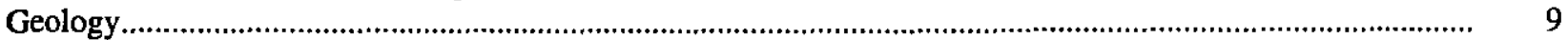

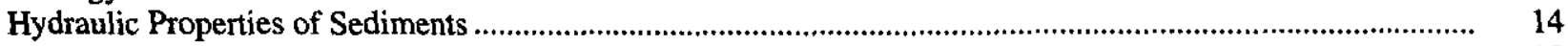

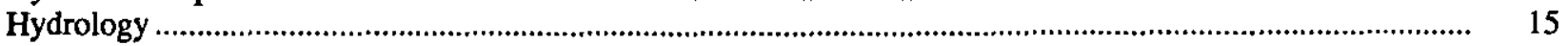

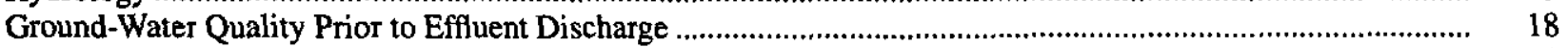

Operation of the Septage-Treatment Facility and Effluent Quality .............................................................................19

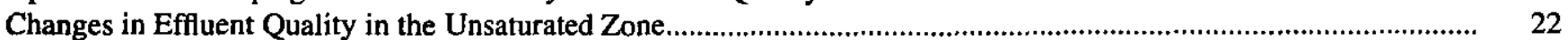

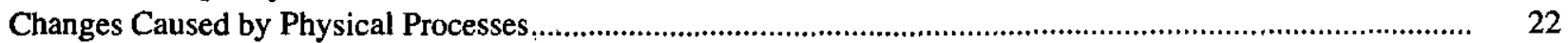

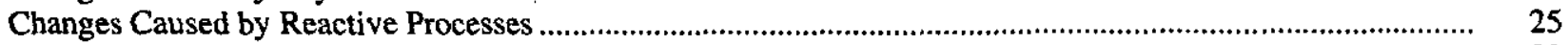

Physical Development and Chemical Characteristics of the Septage-Effluent Plume................................................

Specific Conductance, Chloride, and Physical Development of the Plume ................................................... 29

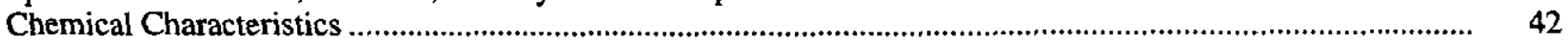

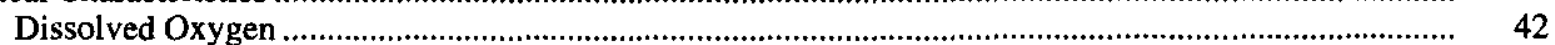

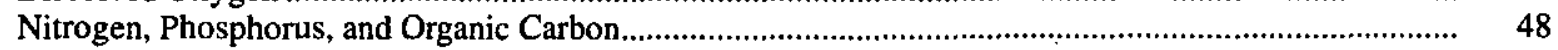

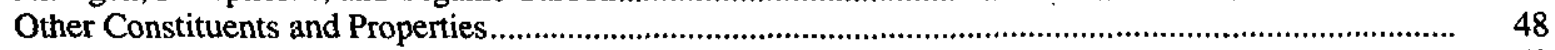

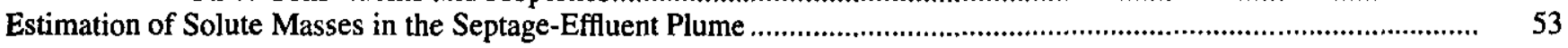

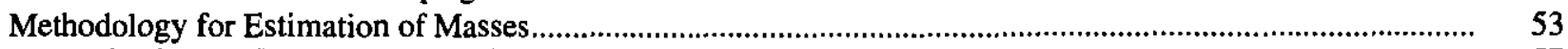

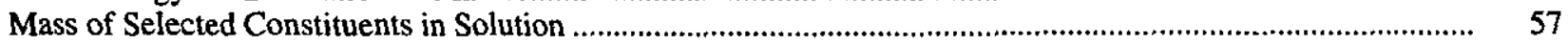

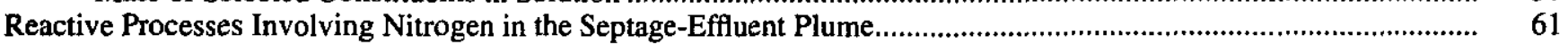

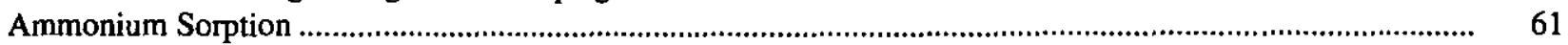

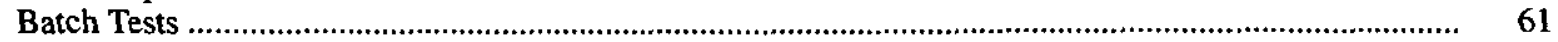

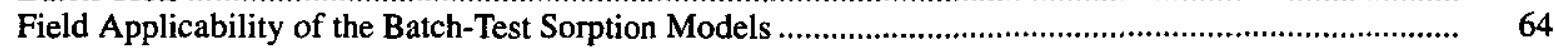

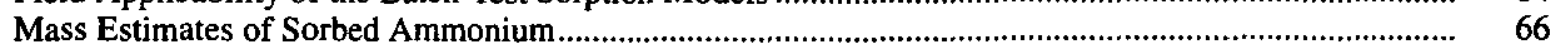

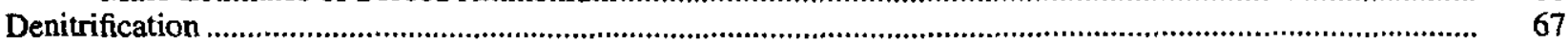

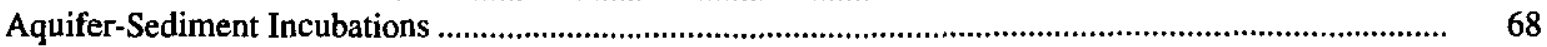

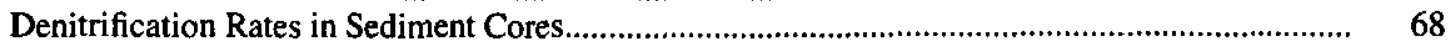

Denitrification Rates in Sediment Slurries and Rates with Nitrate and

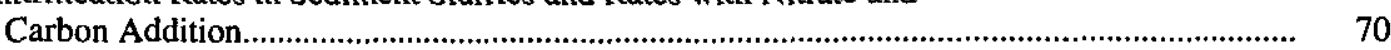

Dinitrogen, Nitrous Oxide, and Dissolved Inorganic Carbon ........................................... 72

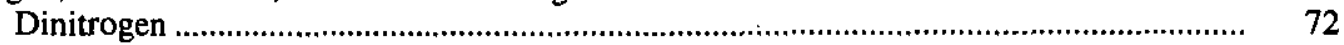

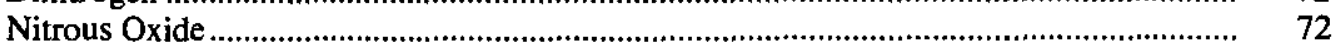

Dissolved Inorganic Carbon ................................................................................. 74

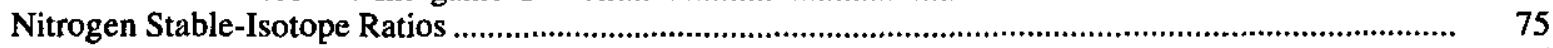

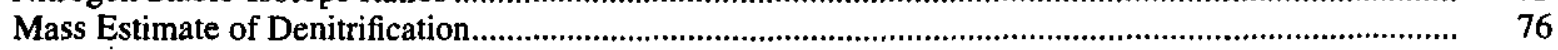




\section{CONTENTS--Continued}

Reactive Processes Involving Nitrogen in the Septage-Effluent Plume-Continued

Summary of Reactive Processes Involving Nitrogen and Nitrogen Budget.......................................................... 77

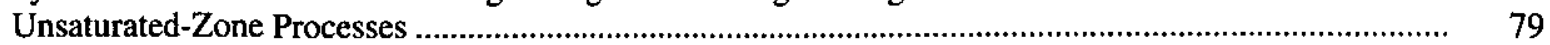

Saturated-Zone Processes.............................................................................................................. 80

Summary

References Cited

\section{FIGURES}

1,2. Maps showing:

1. Location of the Tri-Town Septage Treatment Facility, Orleans, and location of wells outside the study area, Cape Cod, Massachusetts

2. Physical features of the study area, observation-well network, and location of sections,

Orleans, Massachusetts.

3. Hydrogeologic sections showing lithologic units, potentiometric contours, and general direction of ground-water flow along sections $A-A^{\prime}$ and $B-B^{\prime}$ in the study area, December 1992

4. Hydrograph showing water-level fluctuations in the study area, August 1989 through December 1992

5. Map showing altitude of the water table and general direction of ground-water flow in the study area, December 1992

6-8. Graphs showing:

6. Mean daily discharge and total monthly discharge of effluent, February 1990 through December 1992

7. Concentrations of chloride and nitrogen species in effluent and water-table ground water beneath the infiltration beds (well OSW 136), March 1990 through December 1992

9-11. Maps showing:

8. Monthly differences between ion concentrations in water-table ground water and in effluent, January 1991 through December 1992

9. Areal distribution of specific conductance in the septage-effluent plume, December 1992

10. Areal distribution of specific conductance in the septage-effluent plume, March and September 1991 and June and December 1992.

11. Areal distribution of chloride concentrations in the septage-effluent plume, December 1992

12. Hydrogeologic sections showing vertical distribution of specific conductance and electromagnetic-

induction logs along sections $A-A^{\prime}, B-B^{\prime}$, and $C-C^{\prime}$ in the septage-effluent plume, December $1992 \ldots \ldots . . .$.

13,14. Graphs showing:

13. Vertical heterogeneity in the septage-effluent plume illustrated by sequential electromagnetic-induction logs at two sites in the westward lobe

14. Concentrations of chloride, total dissolved nitrogen, and dissolved oxygen with time at five wells at four sites in the septage-effluent plume

15,16. Maps showing:

15. Areal distribution of dissolved oxygen in the septage-effluent plume, December 1992

16. Areal distribution of anoxic conditions in the septage-effluent plume, September 1991, and June and December 1992

17. Schematic diagram showing conceptual model of the development of anoxic conditions in the septage-effluent plume.

18-20. Maps showing:

18. Areal distribution of nitrate in the septage-effluent plume, December 1992.

19. Areal distribution of ammonium in the septage-effluent plume, December 1992

20. Areal distribution of dissolved organic carbon in the septage-effluent plume, December 1992

21. Graphs showing calcium, sodium, potassium, chloride, and boron in ground water from two wells at site 96 in the westward lobe of the septage-effluent plume, March 1991 through December 1992.........

22. Schematic diagram showing vertical integration of concentration data for mass-balance calculations .

23. Map showing triangular elements used for mass-balance calculations. 


\section{CONTENTS--Continued}

\section{4,25. Graphs showing:}

24. Differences between cation masses in the septage-effluent plume and masses input to the aquifer in effluent

25. Ammonium-sorption data from batch tests and calculated isotherms using Freundlich and Langmuir sorption models

26. Illustration of vertical integration of predicted and measured sorbed plus dissolved ammonium concentrations, site 174, September 1992

concentrations:
27-31. Graphs showing:

27. Relation between vertically integrated concentrations of sorbed plus dissolved ammonium based on batch-test sorption models (predicted) and on potassium-chloride extractions of sediments (measured)

28. Frequency distributions of denitrification rates measured in sediment cores

29. Electromagnetic-induction (EM) logs, denitrification rates measured in sediment cores, and concentrations of dissolved oxygen, nitrate, and dissolved organic carbon at two sites in the septage-effluent plume.....

lectromagnetic-induction (EM) $\log$ (April 1992), denitrification rates measured in sediment cores, and concentrations of dissolved oxygen, nitrate, and dissolved organic carbon at site 147, July and December 1991 and April and September 1992

31. Nitrous oxide production in sediment slurries with nitrate and carbon addition

32. Map showing areal distribution of dinitrogen in the septage-effluent plume, December 1992

33,34. Graphs showing:

33. Concentrations of dinitrogen in ground water in three wells at site 96, March 1991 through December 1992.

34. Relations of nitrous oxide and dissolved inorganic carbon concentrations with chloride concentrations in the septage-effluent plume, December 1992

35. Diagram showing nitrogen budget for the septage-effluent plume, February 1990 through December 1992 ..

36. Graphs showing relations of dissolved ammonium concentrations with chloride and dissolved-oxygen concentrations in the septage-effluent plume, December 1992

\section{TABLES}

1. Characteristics of particle-size distribution and hydraulic conductivity of aquifer sediments

2. Cation-exchange capacity and exchangeable-cation concentrations in aquifer sediments

3. Physical properties and concentrations of major chemical constituents, nutrients, and selected trace constituents in ambient (background) ground water in the study area prior to effluent discharge, September 1989.

4. Physical properties and concentrations of major chemical constituents, nutrients, and boron in effluent, March 1990 through December 1992.

5. Physical properties and concentrations of major chemical constituents, nutrients, and boron in water-table ground water beneath the infiltration beds, January 1991 through December 1992, and comparison with physical properties and chemical concentrations in effluent...

(1)

6. Physical properties and concentrations of major chemical constituents, nutrients, and boron in

ground water in the septage-effluent plume, December 1992 ..........................................
7. Comparison of chloride and nitrogen breakthrough curves at five wells at four sites in the septage-effluent plume

8. . Effluent-input masses and solute masses in the septage-effluent plume, March, June, and September 1991, and June and December 1992

9. Linear, Freundlich, and Langmuir sorption models fit to batch-test data for ammonium sorption.

10. Sorbed and dissolved nitrogen masses in the septage-effluent plume, March, June, and September 1991, and June and December 1992

11. Stable-isotope ratios and concntrations of nitrogen species in effluent and ground water, July 1992

12. Location of cluster sites and locations and screened intervals of wells 


\section{CONVERSION FACTORS, VERTICAL DATUM, AND ABBREVIATIONS}

\begin{tabular}{rll} 
Multiply & By & To obtain \\
\hline cubic foot per day $\left(\mathrm{ft}^{3} / \mathrm{d}\right)$ & 0.02832 & cubic meter per day \\
foot $(\mathrm{ft})$ & 0.3048 & meter \\
foot per day (ft/d) & 0.3048 & meter per day \\
gallons per day (gal/d) & 0.003785 & cubic meter per day \\
inch (in.) & 25.4 & millimeter \\
inch per year (in/yr) & 25.4 & millimeter per year \\
mile $(\mathrm{mi})$ & 1.609 & kilometer \\
square foot $\left(\mathrm{ft}^{2}\right)$ & 0.09290 & square meter \\
square mile $\left(\mathrm{mi}{ }^{2}\right)$ & 2.590 & square kilometer \\
Temperature is given in degree Celsius $\left({ }^{\circ} \mathrm{C}\right)$, which can be converted to degree \\
Fahrenheit $\left({ }^{\circ} \mathrm{F}\right)$ by the following equation: \\
${ }^{\circ} \mathrm{F}=1.8\left({ }^{\circ} \mathrm{C}\right)+32$.
\end{tabular}

\section{VERTICAL DATUM}

Sea level: In this report, "sea level" refers to the National Geodetic Vertical Datum of 1929 (NGVD of 1929)--a geodetic datum derived from a general adjustment of the first-order level nets of both the United States and Canada, formerly called Sea Level Datum of 1929.

\section{ABBREVIATIONS}

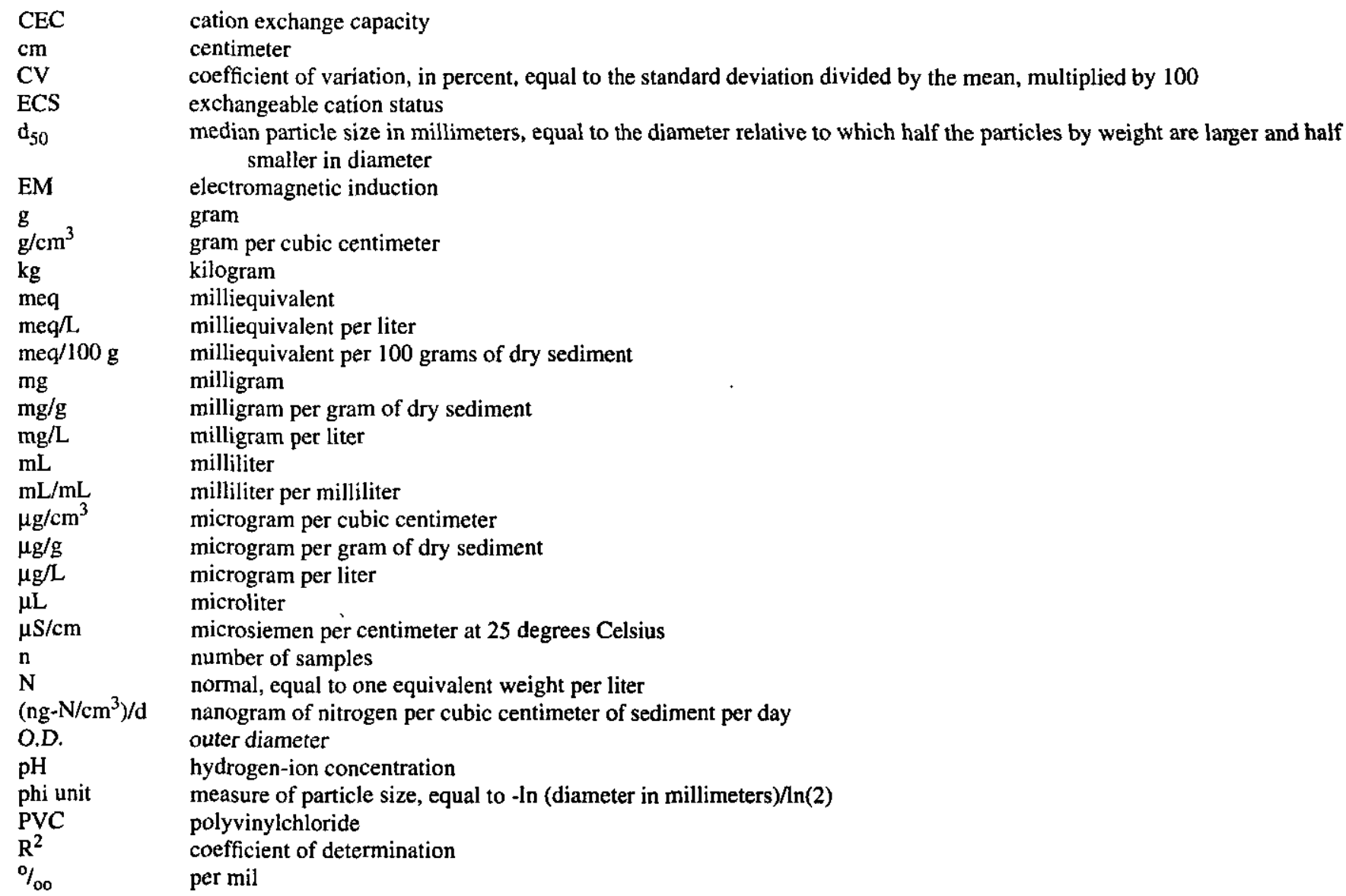




\title{
A NITROGEN-RICH SEPTAGE-EFFLUENT PLUME IN A GLACIAL AQUIFER, CAPE COD, MASSACHUSETTS, FEBRUARY 1990 THROUGH DECEMBER 1992
}

\author{
By Leslie A. DeSimone, Paul M. Barlow, and Brian L. Howes
}

\section{Abstract}

A nitrogen-rich septage-effluent plume was monitored to quantify the physical, chemical, and microbial processes that affect the transport and fate of selected constituents in the plume within the aquifer. The plume of contaminated ground water resulted from the infiltration of wastewater at the Tri-Town Septage Treatment Facility in Orleans, Cape Cod, Massachusetts. The septage-effluent plume was monitored from the beginning of effluent discharge in February 1990 through December 1992. Lithologic, hydrologic, and pre-discharge water-quality data were used to characterize the glacial aquifer. The physical transport and chemical characteristics of the septage-effluent plume were monitored by analyzing water-quality samples from 83 wells. The physical development of the plume also was delineated with borehole electromagnetic-induction logging. Chemical and microbial processes affecting constituents in the plume were inferred from waterquality data, mass-balance analyses, and the direct measurement of reactive processes involving nitrogen (ammonium sorption and denitrification of nitrate).

By December 1992, the septage-effluent plume extended about 200 feet westward and 450 feet northwestward of the infiltration beds. The primary direction of transport was toward aquifer discharge areas in a nearby coastal marsh and Cape Cod Bay. The plume preferentially flowed through a 5- to 60-foot thick lithologic unit of medium to very coarse sand at a mean linear velocity of 0.4 to 0.5 foot per day. Concentrations of total dissolved nitrogen ranged from more than 40 milligrams per liter as nitrogen in the center of the plume to less than 10 milligrams per liter as nitrogen near the boundaries of the plume. Concentrations near the boundaries of the plume were diluted by mixing with ambient ground water, which contained relatively little nitrogen. Nitrate was the primary form of nitrogen in the septage-effluent plume. Lower concentrations of dissolved ammonium were present. The center of the septage-effluent plume in ground water was anoxic. Much of the nitrate in ground water was produced by nitrification of effluent ammonium in the unsaturated zone. The nitrification process in the unsaturated zone decreased the $\mathrm{pH}$ (7.2 in effluent and 5.0 in the septageeffluent plume) and produced high concentrations of dissolved nitrous oxide (as much as 0.4 milligram per liter as nitrogen).

Ammonium sorption was the primary process affecting nitrogen transport in the saturated zone. Sorbed ammonium was about 17 percent of the total nitrogen in the plume in December 1992. Ammonium sorption was best described by a Langmuir isotherm and was strongly dependent on the ionic strength of the aqueous phase. Denitrification, the microbiological reduction of nitrate to dinitrogen gas, was limited by the low dissolved and solid-phase concentrations of organic carbon in the plume. The mean denitrification rates measured in aquifer-core incubations and from dinitrogen production were 9.6 and 3.0 nanograms of nitrogen per cubic centimeter of sediment per day, respectively. The dinitrogen-production rate, which best reflects in situ rates, corresponds to a nitrate reduction of 1.5 milligrams per liter as nitrogen per 100 feet of travel distance under anoxic conditions. Significant attenuation of nitrate concentrations from denitrification was not observed in the field due to the short distance traveled by anoxic ground water and the masking effect of variations in the effluent-nitrogen concentrations during the study. On a mass basis, denitrification had transformed about 2 percent or less of the total nitrogen mass discharged in the effluent or found in the plume by December 1992. Mass-balance analyses also indicated that calcium, sodium, magnesium, potassium, sulfate, and boron were involved in ion exchange and (or) sorption reactions in the unsaturated and saturated zones. 


\section{INTRODUCTION}

Land disposal of municipal wastewater can be a cost-effective alternative to direct discharge to surfacewater bodies. However, infiltration of wastewater also may pose health and environmental problems by contaminating ground water with nitrogen. Ground water containing high concentrations of nitrate-nitrogen can be toxic to small children. Thus, the U.S. Environmental Protection Agency has set a Maximum Contaminant Level of $10 \mathrm{mg} / \mathrm{L}$ as $\mathrm{N}$ for drinking water (Hem, 1985, p. 125). Nitrogen-contaminated ground water that discharges to a surface-water ecosystem also may stimulate plant and algal growth (productivity). Coastal marshes and water bodies are particularly sensitive to nitrogen contamination, because productivity in coastal ecosystems is most often nitrogen limited (Schlesinger, 1991, p. 245). Excessive productivity (or eutrophication) may alter the natural balance of plant and animal species, lead to dissolved-oxygen depletion, and adversely affect fish and shellfish in coastal waters.

The Tri-Town Septage Treatment Facility in Orleans, Cape Cod, Massachusetts (fig. 1) has disposed of treated septage effluent since February 1990. The TriTown Septage Treatment Facility is a municipal facility owned and operated by the Orleans, Brewster, and Eastham Groundwater Protection District. The facility treats septage, the semisolid residue pumped from residential and commercial septic tanks. The treatment facility was constructed in response to recent Federal and State regulations prohibiting open-pit disposal of untreated septage. The treatment produces a nitrogen-rich effluent that is disposed of through infiltration into the sandy aquifer underlying the facility. Infiltration occurs within $1 \mathrm{mi}$ of the regional ground-water discharge area at Cape Cod Bay (LeBlanc and others, 1986) and about $700 \mathrm{ft}$ from the coastal Namskaket Marsh. Namskaket Marsh has been recognized by the Commonwealth of Massachusetts as an Area of Critical Environmental Concern, and the tidal creek that drains the marsh is designated as an Outstanding Resource Water. Thus, the effluent discharge from the septage- treatment facility may affect ground-water quality and valuable coastal resources.

\section{Purpose and Scope}

The U.S. Geological Survey (USGS), in cooperation with the Massachusetts Department of Environmental Protection, Office of Watershed Management, monitored the development of a nitrogen-rich plume resulting from wastewater infiltration from the TriTown Septage Treatment Facility. The purpose of this study was to determine the effects of the effluent discharge on ground-water quality and to determine the factors that controlled the transport of chemical constituents in the septage-effluent plume in ground water. Transport processes involving nitrogen, the constituent of primary concern, were studied in detail.

This report describes (1) the general characteristics of the aquifer, including pre-discharge water quality, (2) quantity and quality of the effluent, (3) changes in effluent quality in the unsaturated zone, (4) physical development and chemical characteristics of the septageeffluent plume, (5) mass-balance estimates of plume constituents, and (6) reactive processes involving nitrogen in the septage-effluent plume. The report is based on data collected from October 1988 through December 1992 (DeSimone, 1995).

\section{Approach}

The geology, sediment hydraulic properties, hydrology, and pre-discharge ground-water quality were determined as part of the general characterization of the aquifer. The aquifer geology was determined from examination of sediment samples collected during well installation, from natural-gamma logs, which can indicate the relative abundance of fine- and coarsegrained sediments (Fetter, 1988, p. 437), and from literature sources. Hydraulic conductivity, used for analysis of plume movement, was determined from particle-size-distribution data, slug tests, and literature sources. Porosity, used for physical-transport and massbalance analyses, was determined from literature sources and aquifer core samples. Description of predischarge water quality was based on the analyses of samples collected in September 1989. 

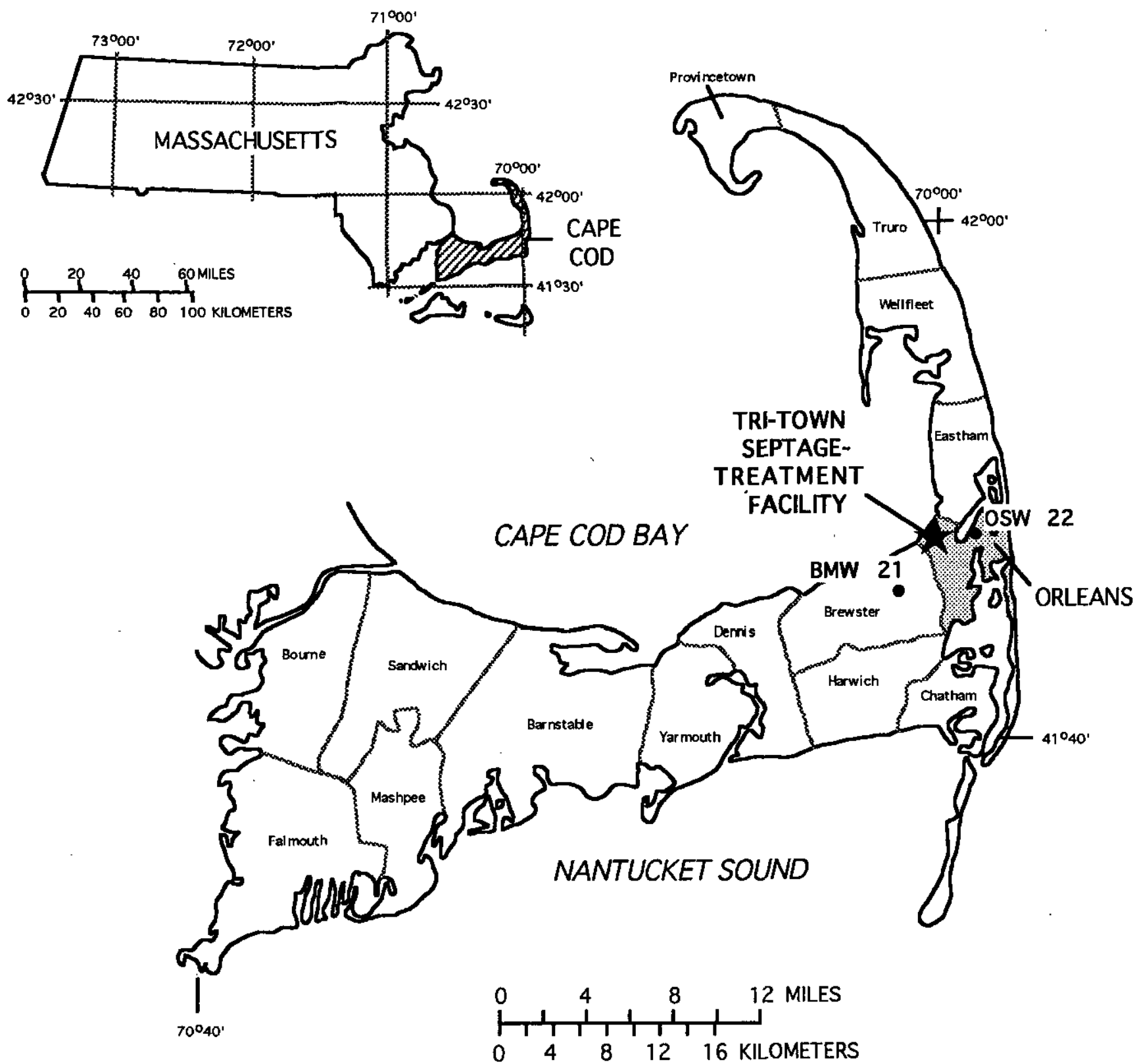

Figure 1. Location of the Tri-Town Septage Treatment Facility, Orleans, and location of wells outside the study area, Cape Cod, Massachusetts. (Modified from Oldale, 1976, and Guswa and LeBlanc. 1985, fig. 1.)

Effluent quality was determined from analysis of water samples collected every 2 weeks to monthly from March 1990 through December 1992. The daily volume of effluent discharge was obtained from facility records. Changes in effluent quality in the unsaturated zone were determined by comparing effluent chemistry with ground-water chemistry at the water table beneath the infiltration beds. This ground water, from a well screened across the water table, was sampled concurrently with effluent samples. 
The physical development and chemical characteristics of the septage-effluent plume in ground water were determined from analysis of ground-water samples and borehole EM (electromagnetic-induction) logs. Monthly ground-water sampling at several cluster sites, June 1990 through December 1992, was used for detailed analysis of physical and reactive transport in the plume. Large-scale (36 to 69 wells) synoptic sampling, March, June, and September 1991, and June and December 1992, was used to describe the distribution of contaminants in the aquifer and to estimate mass losses and gains of dissolved constituents in the plume. Borehole EM logging, concurrent with monthly and synoptic sampling, was used to describe physical transport processes and to calculate mass balances.

Reactive processes involving nitrogen were inferred from nitrogen concentrations in effluent and ground water, measurements of ammonium sorption and denitrification in plume sediments, and solid-phase nitrogen and carbon concentrations. Ammonium sorption and denitrification (the microbial reduction of nitrate to nitrogen gases) were measured directly because they are the processes most likely to attenuate dissolved nitrogen concentrations in the plume. Ammonium sorption was measured with batch tests, sediment extractions, and mass-balance estimates. Denitrification was measured with incubations of sediment cores and slurries, analysis of dissolved nitrogen gases, and nitrogen stable-isotope ratios. Factors controlling denitrification rates were identified through an addition experiment and relation of rates with concentrations in ground water. A nitrogen budget was constructed that compares ammonium sorption, denitrification, and other reactive processes involving nitrogen on a mass basis.

\section{Acknowledgments}

The authors thank the personnel of Tri-Town Septage Treatment Facility and Town of Orleans officials for their assistance and cooperation with this project, especially: Wayne McDonald, District Administrator, and James Burgess, Chief Operator, Orleans, Brewster and Eastham Groundwater Protection District; and Nancy Schwinn, Administrative Assistant, Town of Orleans. The technical laboratory assistance of Dale Goehringer, David White, Susan Brown-Ledger, David Schlezinger, and Newton Millham, Woods Hole Oceanographic Institution, also is greatly appreciated.
Cation-exchange capacity and exchangeable cations analyses were provided by Steven Bodine, University of Massachusetts, Soil and Plant Tissue Lab, Waltham, Mass. X-ray diffraction analyses were provided by L.J. Poppe and A.M. Moffett, USGS, Geologic Division, Woods Hole, Mass. Stable-isotope analyses were completed by a private contractor.

\section{METHODS OF INVESTIGATION}

\section{Observation-Well Network}

A network of 83 ground-water observation wells at 33 cluster sites was installed by the USGS on and nearby the treatment-facility site during the study (fig. 2). The wells were used to monitor water-level fluctuations and ground-water quality. Wells were installed in the anticipated path of the plume in phases. These wells were located and screened based on lithologic, water-level, borehole-geophysical, and waterquality data collected throughout the study. Wells were installed using hollow-stem augers and consist of 2-inch inner diameter polyvinylchloride (PVC) pipe, with 1-, 5- or 10-foot-long slotted PVC screens (slot size 0.010 in.). Water levels also were measured in nine additional wells installed at the site by private engineering firms, and OSW 25, a USGS well within $0.5 \mathrm{mi}$ of the site that has been used to monitor water-level fluctuations in the aquifer since 1975. The locations of cluster sites and locations and screened intervals of wells are provided in table 12 (at back of report). In this report, individual wells are referred to using the prefix "OSW," whereas cluster-site locations are referred to by number only.

\section{Sediment Sampling}

Sediment samples for ammonium-sorption and denitrification measurements were collected with a Waterloo wireline-piston core barrel (Zapico and others, 1987). The core barrel is designed to retain pore water in the sample and is used with a hollow-stem auger drill rig. A 2-inch-diameter core, up to $5 \mathrm{ft}$ in length, was collected in an aluminum core liner. Cores were sealed immediately on collection and held on ice or at $4^{\circ} \mathrm{C}$. Incubations of aquifer sediments were begun within 12 hours of collection for sediment core methods and extractions and within 48 hours for slurry incubations. At least $4 \mathrm{in}$. from each end of the cores was discarded to prevent drilling fluids from contaminating incubation sediments. 


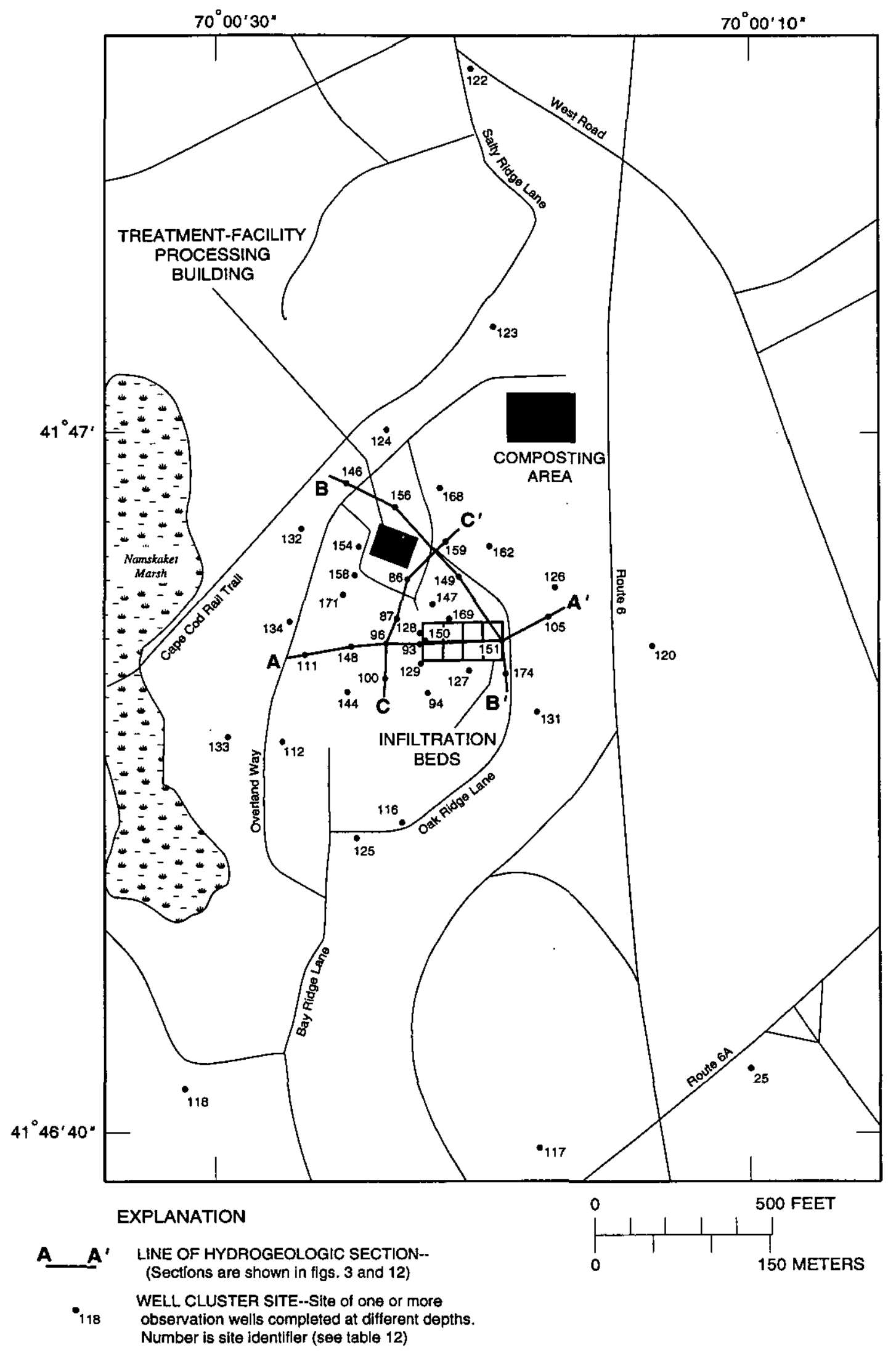

Figure 2. Physical features of the study area, observation-well network, and location of sections, Orleans, Massachusetts. 
Sediment samples for lithologic determination were collected using a split-spoon sampler or the wireline-piston core barrel at irregular intervals during drilling. Sand-, silt-, and clay-sized fractions were determined for 25 samples (R.A. Ludlow, U.S. Geologicàl Survey, written commun., November 1989 and January 1993). The sand-sized fractions of an additional 78 samples were determined using standard particle-size sieve-analysis techniques (Guy, 1969).

\section{Effluent and Ground-Water Sampling}

Effluent samples were collected either from the treatment facility's 8-hour composite sampler or directly from the distribution system during discharge. Ground-water samples were collected using a stainless steel submersible pump or a Teflon ${ }^{1}$ bailer after removal of at least three well volumes. Effluent and groundwater samples were analyzed for field parameters and concentrations of major chemical constituents (chloride only for monthly ground-water samples), dissolved nitrogen and phosphorus species, dissolved organic carbon, and boron. Total nitrogen, total phosphorus, and total organic carbon also were measured in effluent samples collected from March through December 1992. Samples were filtered (dissolved constituents), preserved with nitric acid (cations), light exclusion and mecuric chloride (nitrogen and phosphorus), or light exclusion and silver filtration (dissolved organic carbon), and chilled on site; the samples were shipped on ice to the USGS water-quality laboratory in Denver, Colorado, for analysis (Wershaw and others, 1987; Fishman and Friedman, 1989).

Ground-water samples for analysis of dissolved dinitrogen, nitrous oxide, and inorganic carbon also were collected during synoptic samplings. Samples for analysis of dissolved dinitrogen and nitrous oxide concentrations were collected with a syringe; $15-\mathrm{mL}$ samples were injected into sealed $25-\mathrm{mL}$ serum bottles. The serum bottles contained $0.1 \mathrm{~mL} 8-\mathrm{N}$ sodium hydroxide (a preservative) and were flushed with helium immediately prior to sampling (Smith and others, 1991). Samples for analysis of dissolved inorganic carbon also were collected with a syringe; 5-mL samples were injected into sealed $15-\mathrm{mL}$ serum bottles. These bottles

\footnotetext{
${ }^{1}$ Use of brand names in this report is for identification purposes only and does not constitute endorsement by the U.S. Geological Survey.
}

contained air headspace and were later injected with 0.5 $\mathrm{mL} 2-\mathrm{N}$ sulfuric acid (to transform all inorganic carbon to dissolved carbon dioxide; Smith and others, 1991). Triplicate samples were collected for all three analyses. Dinitrogen samples were analyzed within $12 \mathrm{~h}$ of collection; nitrous oxide and dissolved inorganic carbon samples were analyzed within 2 to 5 days of collection.

Ground-water and effluent samples for analysis of nitrogen stable-isotope ratios were collected in $1-\mathrm{L}$ acid-washed glass bottles using the submersible pump (ground-water samples) or a peristaltic pump (effluent samples) with in-line filtration. Samples for analysis of stable-isotope ratios in dissolved dinitrogen gas were collected with the sample bottle submerged in an 8 -L glass overflow vessel. The sample bottle was filled with the filter-discharge line placed at the bottom of the bottle. The sample was collected after the overflow vessel was filled at least to capacity. The sample bottle was sealed while submerged with a gas-tight rubber stopper. Samples were shipped on ice to a private contractor for analysis.

\section{Borehole Electromagnetic-Induction Surveying}

Borehole EM logs were made with a Geonics EM 39 borehole conductivity logger. The logger measures the total electrical conductivity of the aquifer sediments and pore water (McNeill, 1986). The maximum response of the probe to aquifer conductivity occurs at a radial distance of about $1 \mathrm{ft}$ from the center of the borehole (McNeill, 1986). Because the effluent had a high specific conductance relative to background values, the EM logger readily detected the septageeffluent plume in ground water as zones of high electrical conductivity. The EM logger was used to determine the presence or absence, thickness, and variability with depth of the plume at cluster sites. The logs also were used to determine optimum depths to install new wells for water-quality sampling.

\section{Ammonium-Sorption Methods}

Four batch tests on three uncontaminated sediment samples were conducted following a procedure similar to that of Ceazan and others (1989). The sediment samples consisted of silty fine to medium sand. Each sediment sample was homogenized and divided into $15-\mathrm{g}$ subsamples. Subsamples were combined with $30 \mathrm{~mL}$ of 
ambient ground water, double-distilled water, or a solution similar in ionic composition to the effluent (artificial effluent). The artificial-effluent solution contained concentrations of $860 \mathrm{mg} / \mathrm{L}$ of chloride, $400 \mathrm{mg} / \mathrm{L}$ of calcium, and $100 \mathrm{mg} / \mathrm{L}$ of sodium and was prepared using double-distilled water. The sediment slurries were spiked with a concentrated solution of ammonium chloride, resulting in 12 initial ammonium concentrations ranging from 0.1 to $90 \mathrm{mg} / \mathrm{L}$ as $\mathrm{N}$. Two sediment replicates per concentration were used in each batch test. As a control, a liquid-only replicate (no sediment) also was prepared for each concentration. Samples and controls were incubated in a mechanical shaker at $4^{\circ} \mathrm{C}$ to minimize microbial reactions involving ammonium. After 24 hours, slurries were centrifuged, and the supernatant was filtered $(0.45-\mu \mathrm{m}$ filter $)$ and analyzed for dissolved ammonium concentration. The ammonium sorbed by each sediment subsample was calculated as the difference between the initial and final concentrations in the liquid. Initial concentrations were calculated from the ammonium concentrations and volumes of the pore water, added liquid, and ammonium spike.

Sorbed ammonium was measured at six sites in the septage-effluent plume on seven occasions (April to September 1992), at two uncontaminated sites (May 1992), and in two infiltration beds (March to April 1992). Sediment was extracted in duplicate by combining $20 \mathrm{~g}$ wet sediment with $30 \mathrm{~mL}$ of $2-\mathrm{N} \mathrm{KCl}$ (potassium chloride) solution. Samples periodically were shaken and extracted for at least 24 hours at $4^{\circ} \mathrm{C}$. At the end of the extraction period, the tubes were centrifuged and the supernatant was filtered as in the batch tests. Concentrations were measured in weight-per-weight units and converted to weight-per-volume units.

\section{Denitrification Methods}

\section{Sediment-Core Incubations}

Measurements of denitrification rate in sediment cores were made at six sites in the septage-effluent plume in ground water on 10 occasions from July 1991 through September 1992. Cores were collected at about 5- to 10 -foot intervals vertically through the plume. Denitrification rates were determined from an acetylene-block technique and measurement of nitrous oxide (Balderston and others, 1976; Yoshinari and others,
1976). The aluminum-encased cores were sectioned into 5.5-inch segments under a helium atmosphere. Two to three vertically adjacent, 5.5 -inch segments were prepared from most ( 90 percent) cores as replicates. Acetylene was introduced into each saturated core segment by a central vertical-line injection of $15 \mathrm{~mL}$ of acetylene-saturated ground water. Cores were sealed and incubated at in situ temperature $\left(11\right.$ to $12^{\circ} \mathrm{C}$ ) for 5 to 7 days. The incubation period was guided by concurrent slurry incubations and was selected to maximize nitrous oxide production and ensure adequate acetylene diffusion. Acetylene-diffusion rates were estimated using an analytical solution for diffusion from an instantaneous cylindrical source into an infinite volume (Crank, 1979, p. 30). This analysis determined that dissolved acetylene concentrations would reach at least 2 percent (volume by volume) at the edges of the core after 7 hours; concentrations of nearly 10 percent would be achieved throughout the core segment after 1 day. These concentrations are sufficient to inhibit nitrous oxide reduction (Ryden and others, 1979; Tiedje, 1982; Tiedje and others, 1989).

Denitrification rates were calculated from nitrous oxide production for the incubation period. Initial nitrous oxide content was determined from pore-water content of the core segment, which was measured gravimetrically. Concentrations of in situ nitrous oxide were measured in ground water from wells screened at appropriate depths at each sampling site during core collection. Cores were harvested at the end of the incubation period for measurement of nitrous oxide by headspace equilibration by (1) upward displacement of pore water, collection with a gas-tight syringe, and injection into gas-tight serum bottles, or (2) transferral of the core sediment and pore water to a gas-tight glass jar with a sampling septum. Measurements were made in weight-perweight units and converted to weight-per-volume units.

\section{Sediment-Slurry Incubations}

Denitrification rates in sediment slurries using an acetylene-block technique (Balderston and others, 1976; Yoshinari and others, 1976) were determined on six occasions from three sites in the septage-effluent plume in ground water from July 1991 to May 1992. An addition test was done in December 1992 with sediments from a centrally located site. At that time, the site had been in the anoxic zone of the plume for at least 1 year. 
Slurries consisted of $50 \mathrm{~g}$ of sediment and pore water plus $50 \mathrm{~mL}$ of added ground water (collected from a well at the sampling site screened at the same or similar depth as the sediment sample) in $125-\mathrm{mL}$ serum bottles. In the addition experiment, concentrated solutions of potassium nitrate and(or) glucose were added to obtain dissolved concentrations in the slurry water of 69 $\mathrm{mg} / \mathrm{L}$ as $\mathrm{N}$ and $170 \mathrm{mg} / \mathrm{L}$ as carbon, respectively. Controls were prepared by adding $0.4 \mathrm{~mL} 8-\mathrm{N}$ sodium hydroxide to prevent microbial growth. Two or three replicate bottles were prepared for each sample. Slurries were bubbled with oxygen-free helium for $10 \mathrm{~min}$, sealed, and flushed with helium for an additional $5 \mathrm{~min}$. Analysis of headspace composition using gas chromatography showed that this procedure resulted in an oxygen-free slurry. Acetylene ( $9 \mathrm{~mL}$ ) was injected into each gas-tight bottle, and the bottles were vigorously shaken. Slurries were incubated at in situ temperature. Nitrous oxide concentrations in the headspace were measured during a 5- to 7-day period. Headspace gas ( $200 \mu \mathrm{L}$ to $1 \mathrm{~mL}$ ) was withdrawn with a gas-tight syringe through the rubber serum stopper and replaced with an equal volume of helium. Denitrification rates were calculated separately for each replicate using a linear regression of nitrous oxide production against time for the linear portion of the curve. Measurements were made in weight-per-weight units and converted to weight-per-volume units.

\section{Analytical Methods}

Field measurements of specific conductance, temperature, $\mathrm{pH}$, and dissolved oxygen were made during sample collection. Specific conductance was measured with a temperature-compensated digital meter (Hach 44600). $\mathrm{pH}$ was measured with a digital meter (Beckman model Phi 11) equipped with a combination glass electrode (Orion) and an automatic temperature compensator. Dissolved-oxygen concentrations were measured using a temperature-compensated digital meter equipped with a pressure-compensated electrode (YSI 58 ). The electrode was placed in the well at or near the screen and below the submersible pump. This procedure minimized atmospheric contact and created flow past the probe. Dissolved-oxygen concentrations less than $1 \mathrm{mg} / \mathrm{L}$ were measured colorimetrically (Chemetrics, Inc., Calverton, Va.).
Concentrations of nitrous oxide, dinitrogen, and dissolved inorganic carbon were measured by headspace equilibration. Nitrous oxide concentrations were measured with a gas chromatograph equipped with a ${ }^{63} \mathrm{Ni}$ electron capture detector $\left(300^{\circ} \mathrm{C}\right)$. A Porapak $\mathrm{N}$ column (0.14 in. O.D., 2.17 plus $4.36 \mathrm{ft}$ ) with a six-port backflush valve (to vent the acetylene) at $90^{\circ} \mathrm{C}$ was used, with methane ( 5 percent) and argon ( 95 percent) carrier gas (Smith and Duff, 1988; Smith and others, 1991). Dinitrogen concentrations were measured with a gas chromatograph equipped with a thermal conductivity detector. Porapak Q (0.14-inch O.D., $7.87 \mathrm{ft})$ and Molecular Sieve 5A (0.14-inch O.D., $5.91 \mathrm{ft}$ ) columns at $60^{\circ} \mathrm{C}$ were used with helium carrier gas (Smith and others, 1991). Samples for measurement of dissolved inorganic carbon were acidified with $0.5 \mathrm{~mL} 2-\mathrm{N}$ sulfuric acid, and carbon dioxide concentrations were measured with an infrared analyzer (Beckman; Howes and others, 1985). Dissolved gas concentrations were calculated from headspace concentrations using the appropriate Bunsen coefficient (Matthess, 1982; Tiedje, 1982) and sample temperature and pressure.

Dissolved ammonium concentrations in batch tests and $\mathrm{KCl}$ extractions were measured using an indophenol-blue technique modified from Scheiner (1976). This method is similar to method I-2523-85 of Fishman and Friedman (1989). Concentration was determined from absorbance at 635 nanometers with a spectrophotometer equipped with a tungsten lamp. The standard curve was prepared from 6 to 10 concentrations, each measured in duplicate. Standard solutions were prepared with double-distilled water from a 100 millimolar solution of ammonium chloride, usually on the same day as sample analysis or within 3 days prior to use and stored at $4^{\circ} \mathrm{C}$. Each sample concentration also was measured in duplicate.

Solid-phase carbon and nitrogen concentrations were measured with an elemental analyzer. The analyses were performed on dry $\left(60^{\circ} \mathrm{C}\right)$ whole sediment and on the silt- and clay-sized (less than $0.063 \mathrm{~mm}$ in diameter) fractions. The accuracy of the analysis was \pm 5.0 percent and was maintained by including a blank or standard after every seven samples.

Nitrogen stable-isotope ratios of dissolved nitrateand ammonium-nitrogen (Minagawa and others, 1984) and dissolved dinitrogen gas (Miyake and Wada, 1967) 
were determined by a private contractor. Stable-isotope ratios of total dissolved nitrogen (all species except dinitrogen) were obtained as $\delta^{15} \mathrm{~N}$ ratios in nitrate after oxidation of total nitrogen in the filtered samples to nitrate using persulfate digestion (D'Elia and others, 1977). Nitrogen stable-isotope ratios are reported in per mil $(\%)$ as $\delta^{15} \mathrm{~N}$, where

$$
\delta{ }^{15} \mathrm{~N}=\frac{\left({ }^{15} \mathrm{~N} /{ }^{14} \mathrm{~N}_{\text {sample }}\right)-\left({ }^{15} \mathrm{~N} /{ }^{14} \mathrm{~N}_{\text {standard }}\right)}{\left({ }^{15} \mathrm{~N} /{ }^{14} \mathrm{~N}_{\text {standard }}\right)} \times 1,000, \text { (1) }
$$

where ${ }^{15} \mathrm{~N} /{ }^{4} \mathrm{~N}_{\text {sample }}$ is the ratio of ${ }^{15} \mathrm{~N}$ to ${ }^{14} \mathrm{~N}$ in the sample and ${ }^{15} \mathrm{~N} /{ }^{14} \mathrm{~N}_{\text {standard }}$ is the ratio of ${ }^{15} \mathrm{~N}$ to ${ }^{14} \mathrm{~N}$ in air. The mean standard deviation of nine duplicate analyses was $0.1 \%$. A laboratory-check standard solution of nitrate and ammonium was analyzed with each set of samples. This solution was prepared from double-distilled water and $20 \mathrm{mg} / \mathrm{L}$ as $\mathrm{N}$ each potassium nitrate $(+3.50 \%)$ and ammonium sulfate $(+0.55 \%$; Kendall and Grim, 1990; Carol Kendall, U.S. Geological Survey, written commun, September 1991). Based on analysis of the standards, the $\delta^{15} \mathrm{~N}$ ratios for samples analyzed in July 1992 were adjusted by $+0.8 \%$. The January 1993 results were within $0.2 \%$ of the known values and were not adjusted.

\section{GENERAL CHARACTERISTICS OF THE GLACIAL AQUIFER}

\section{Geology}

The geology of Cape Cod has been described in detail by Strahler (1966), Oldale $(1976,1982)$, and Oldale and Barlow (1986). Surficial geology near the septage-treatment facility was described by Oldale (1969a) and Oldale and others (1971). Cape Cod is underlain by glacial deposits of the Pleistocene epoch that include stratified outwash, lake, and morainal deposits. The septage-treatment facility overlies stratified drift near the ice-contact head of the Harwich outwash plain (Oldale, 1982). Glacial lake sediments interfinger with the outwash deposits along the western and northern edges of the study area (Oldale and others, 1971). The glacial outwash and lake sediments in the study area have a combined thickness of 300 to $400 \mathrm{ft}$, and most likely rest directly upon crystalline Paleozoic or Precambrian basement (Oldale and Tuttle, 1964, 1965; Oldale, 1969b).

The stratified glacial drift underlying the study area consists primarily of sand, with lesser amounts of silt and gravel, discontinuous lenses of clayey silt and silty clay, and occasional large granitic boulders near the surface. Mineralogical analysis of 19 sediment samples using X-ray diffraction techniques (L.J. Poppe and A.M. Moffett, U.S. Geological Survey, written commun., December 1990) indicates that the predominant minerals composing the sand- and silt-sized fractions are quartz and feldspar ( 62 and 18 percent by weight, respectively), with plagioclase more abundant than potassium feldspar (mean plagioclase:potassium feldspar ratio is 1.5 to 1 ). Accessory minerals, including amphibole (probably hornblende) and siderite, also are present. The clay-sized fraction consists primarily of illite-mica (49 percent of the clay-sized fraction), kaolinite (26 percent), mixed-layer illite-smectite (12 percent), and chlorite (11 percent). Glauconite, a marine sedimentary mineral, also was detected in trace quantities in all samples analyzed. Thus, in addition to an igneous or metamorphic source rock (McMasters and Garrison, 1966), the deposit also has a coastal-plain source. Glauconite and limonite were the most abundant minerals after quartz and feldspar in outwash sediments from Falmouth, Cape Cod (Barber, 1990). In these sediments, the small silt- and clay-sized fraction (less than 1 percent) was mostly quartz and feldspar, although kaolinite and illite also were present.

Aquifer sediments in the study area ranged in size from very fine to very coarse sand, contained variable quantities of silt, and commonly were poorly to moderately well sorted. Characteristics of particle-size distribution of aquifer sediments (grouped according to lithologic units, described below, and sediment type within each unit) are presented in table 1. Median particle size $\left(d_{50}\right)$ varied more than three orders of magnitude from $0.0048 \mathrm{~mm}$ for a sample of clayey silt to $0.98 \mathrm{~mm}$ for one sample of very coarse to coarse sand. Mean graphic standard deviation within sediment type (a measure of sorting, Folk, 1974) ranged from 1.03 to $1.74 \mathrm{phi}$ units (table 1). 
Table 1. Characteristics of particle-size distribution and hydraulic conductivity of aquifer sediments

[Samples for particle-size analyses were not collected for the lower coarse-grained unit. Graphic standard deviation from Folk (1974). Phi units equal to -ln (diameter in millimeters $) / \ln (2)$.--, no data]

\begin{tabular}{|c|c|c|c|c|c|c|c|c|c|}
\hline \multirow[b]{2}{*}{ Lithologic unit and sediment type } & \multirow[b]{2}{*}{$\begin{array}{l}\text { Number } \\
\text { of samples }\end{array}$} & \multicolumn{2}{|c|}{$\begin{array}{c}\text { Particle-size diameter } \\
\text { (millimeters) }\end{array}$} & \multirow{2}{*}{$\begin{array}{c}\text { Mean } \\
\text { graphic } \\
\text { standard } \\
\text { deviation } \\
\text { (phi units) }\end{array}$} & \multirow[b]{2}{*}{$\begin{array}{l}\text { Percentage } \\
\text { of gravel }\end{array}$} & \multirow[b]{2}{*}{$\begin{array}{l}\text { Percentage } \\
\text { of sand }\end{array}$} & \multirow[b]{2}{*}{$\begin{array}{l}\text { Percentage } \\
\text { of silt } \\
\text { and clay }\end{array}$} & \multicolumn{2}{|c|}{$\begin{array}{l}\text { Hydraulic conductivity } \\
\text { (feet per day) }\end{array}$} \\
\hline & & $\begin{array}{c}10 \text { th } \\
\text { percentile }\end{array}$ & $\begin{array}{c}50 \text { th } \\
\text { percentile }\end{array}$ & & & & & $\begin{array}{c}\text { Method } \\
\text { of Hazen } \\
\text { (1893) }\end{array}$ & $\begin{array}{l}\text { Method of } \\
\text { Krumbein } \\
\text { and Monk } \\
(1943)\end{array}$ \\
\hline
\end{tabular}

\begin{tabular}{|c|c|c|c|c|c|c|c|c|c|}
\hline \multicolumn{10}{|c|}{ Upper Fine-Grained Unit } \\
\hline Sand, fine to medium ........................................ & 5 & 0.09 & 0.22 & 1.09 & 2.5 & 92.4 & 5.1 & 26 & 20 \\
\hline Sand, fine to medium, with silt...................... & 6 & .04 & .21 & 1.83 & 3.7 & 80.4 & 16.0 & 9.6 & 7.7 \\
\hline Sand, fine to very fine, with silt........................ & 14 & .03 & .14 & 1.74 & .8 & 73.3 & 24.6 & 3.6 & 4.3 \\
\hline 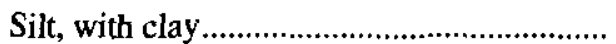 & 1 & .0011 & .0048 & 3.28 & 0 & 23.1 & 76.9 & .004 & .0005 \\
\hline Average for the unit & 26 & .04 & .16 & 1.69 & 2.5 & 76.7 & 20.9 & 9.4 & 7.9 \\
\hline \multicolumn{10}{|c|}{ Intermediate Coarse-Grained Unit } \\
\hline Sand, very coarse to coarse, with gravel ..... & 17 & 0.22 & 0.98 & 1.43 & 16.2 & 77.6 & $\overline{3.2}$ & 190 & 350 \\
\hline Sand, coarse to medium & 18 & .16 & .47 & 1.09 & 2.8 & 94.0 & 3.3 & 96 & 93 \\
\hline Sand, medium to fine & 5 & .07 & .19 & 1.24 & 2.4 & 87.4 & 10.3 & 20 & 17 \\
\hline Average for the unit & 40 & .17 & .65 & 1.25 & 8.4 & 86.2 & 4.1 & 130 & 194 \\
\hline \multicolumn{10}{|c|}{ Lower Fine-Grained Unit } \\
\hline Sand, medium to fine & 3 & 0.10 & 0.27 & 1.03 & 0.9 & 85.5 & 13.5 & 36 & 32 \\
\hline Sand, medium to fine, with silt ........................ & 8 & .05 & .21 & 1.41 & 1.8 & 86.8 & 11.3 & 10 & 11 \\
\hline Sand, very fine to fine, with silt......................... & 11 & .04 & .13 & 1.40 & .6 & 80.8 & 18.6 & 8.2 & 6.3 \\
\hline Average for the unit & 22 & .06 & .18 & 1.36 & .8 & 83.8 & 15.1 & 13 & 12 \\
\hline \multicolumn{10}{|c|}{ Samples from None of the Above Units } \\
\hline Sand, coarse to very coarse, with gravel ..... & 3 & 0.16 & 0.74 & 1.54 & 14.1 & 81.2 & 4.8 & 110 & 140 \\
\hline Sand, medium to coarse & 3 & .15 & .37 & 1.07 & 2.6 & 94.4 & 3.0 & 83 & 62 \\
\hline Sand, medium to very fine & 6 & .06 & .21 & 1.48 & 2.6 & 83.7 & 13.7 & 11 & 11 \\
\hline Sand, very fine, silt and clay............................ & 5 & .04 & .09 & 1.07 & 0 & 65.1 & 34.9 & -- & 4.4 \\
\hline
\end{tabular}


Cation-exchange capacity (CEC) of aquifer sediments in the study area ranged from $0.5 \mathrm{meq} / 100 \mathrm{~g}$ for very coarse to coarse sand with gravel to 2.0 meq/100 $\mathrm{g}$ for fine to very fine sand with silt and clay (table 2). CEC was correlated with percentage of silt and clay (Kendall's tau correlation coefficient $=0.69$, $p=0.0001, \mathrm{n}=18$ ). A correlation was expected because the greatest density of exchange sites is associated with clay minerals and accessory minerals such as micas, rather than with sand-sized quartz and feldspar grains (Marshall and Holmes, 1979). The measured CEC's are typical of sandy sediments and reflect the dominant clay minerals present, illite, kaolinite, and chlorite, which have relatively low cation-exchange capacities (Drever, 1988). The CEC's of coarse-grained samples are similar to reported values for coarse-grained glacial outwash sediments (Dance and Reardon, 1983; Ceazan and others, 1989). The exchangeable cations in uncontaminated sediments were primarily calcium and magnesium, which were present in subequal concentrations (table 2). Sorbed potassium was present in concentrations about an order of magnitude lower than sorbed calcium or magnesium concentrations (table 2). The method used to determine exhangeable cations (Shoemaker and others, 1961) could not measure exchangeable sodium; however, analysis of five sediment samples for recoverable sodium by a different method (Fishman and Friedman, 1989, p. 425) indicated that recoverable sodium was a small fraction ( 0.1 to 2.5 percent) of the total recoverable cations.

Aquifer lithology in the study area is vertically and horizontally heterogeneous, as is typical of glacial-drift deposits. However, four lithologic units were identified: (1) an upper fine-grained unit consisting of fine to very fine or fine to medium sand, with varying amounts of silt, 40 to $60 \mathrm{ft}$ thick; (2) an intermediate coarse-grained unit consisting of medium to very coarse sand, locally with some gravel, 5 to $60 \mathrm{ft}$ thick; (3) a lower finegrained unit of interbedded fine to very fine and medium to fine sand with silt, 35 to $60 \mathrm{ft}$ thick; and (4) a lower coarse-grained unit of medium to coarse sand of undetermined thickness. Most of the upper fine-grained unit lies above the water table (figs. $3 A-B$ ). The intermediate coarse-grained unit is thinnest at the western end of the infiltration beds and reaches maximum thickness eastward and southward (figs. $3 A-B$ ). West of the infiltration beds, the unit slopes downward and interfingers with the upper fine-grained unit (fig. 3A). The thickness of the lower fine-grained unit also is highly variable. The lower boundary of the lower fine-grained unit was not encountered at most sites. This three-to-four lithologicunit sequence, however, cannot be recognized in all parts of the study area.

Table 2. Cation-exchange capacity and exchangeable-cation concentrations in aquifer sediments

[Median particle size is the diameter of a particle of such size that 50 percent of the particles by weight is finer. $\mathrm{mm}$, millimeter]

\begin{tabular}{|c|c|c|c|c|c|c|c|}
\hline \multirow[b]{2}{*}{ Sediment type } & \multirow[b]{2}{*}{$\begin{array}{l}\text { Number } \\
\text { of } \\
\text { samples }\end{array}$} & \multirow{2}{*}{$\begin{array}{c}\text { Median } \\
\text { particle } \\
\text { size } \\
(\mathrm{mm})\end{array}$} & \multirow{2}{*}{$\begin{array}{l}\text { Percent- } \\
\text { age of } \\
\text { silt and } \\
\text { clay }\end{array}$} & \multicolumn{4}{|c|}{$\begin{array}{l}\text { Cation-exchange properties } \\
\text { (milliequivalents per hundred grams of dry sediment) }\end{array}$} \\
\hline & & & & $\begin{array}{l}\text { Mean } \\
\text { cation- } \\
\text { exchange } \\
\text { capacity }\end{array}$ & $\begin{array}{c}\text { Mean } \\
\text { exchange- } \\
\text { able calcium }\end{array}$ & $\begin{array}{l}\text { Mean } \\
\text { exchange- } \\
\text { able } \\
\text { magnesium }\end{array}$ & $\begin{array}{c}\text { Mean } \\
\text { exchangeable } \\
\text { potassium }\end{array}$ \\
\hline $\begin{array}{l}\text { Sand, very coarse to } \\
\text { coarse, with gravel............. }\end{array}$ & 4 & 1.00 & 2.0 & 0.5 & 0.27 & 0.20 & 0.04 \\
\hline Sand, coarse to medium........ & 6 & .44 & 3.9 & .5 & .28 & .21 & .03 \\
\hline Sand, medium to fine ............. & 1 & .20 & 6.5 & .9 & .66 & .19 & .05 \\
\hline 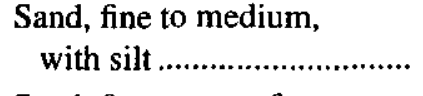 & 2 & .22 & 20.5 & 1.4 & .66 & .77 & .07 \\
\hline $\begin{array}{l}\text { Sand, fine to very fine, } \\
\text { with silt and clay.................. }\end{array}$ & 8 & .11 & 27.4 & 2.0 & .93 & .84 & .08 \\
\hline
\end{tabular}




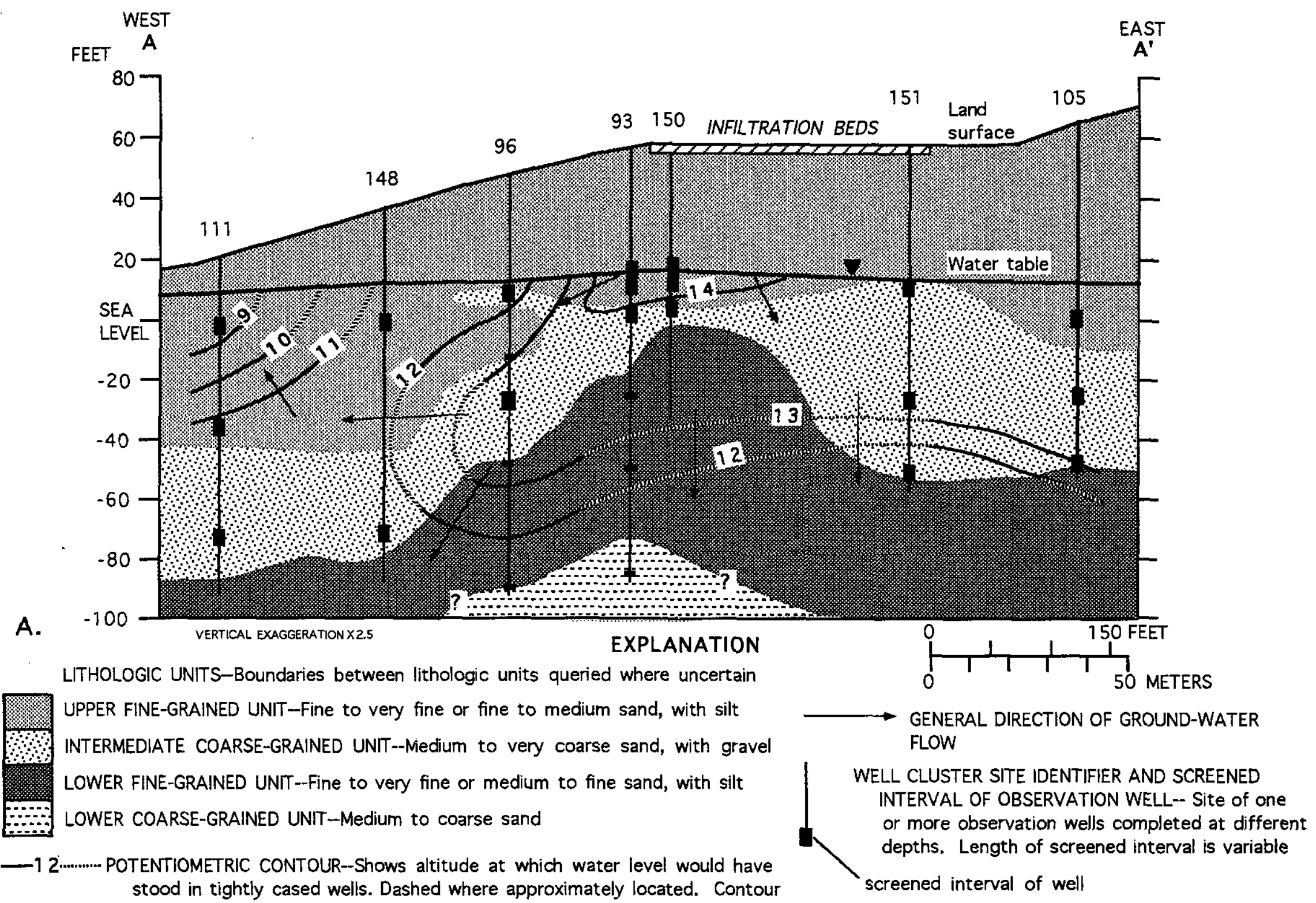
stood in tightly cased wells. Dashed where approximately located. Contour interval, 1 foot. Datum is sea level

Figure 3. Lithologic units, potentiometric contours, and general direction of ground-water flow along $(A)$ section $A-A^{\prime}$ and $(B)$ section $B-B^{\prime}$ in the study area, December 1992. (Line of hydrogeologic sections shown in figure 2.) 


\section{NORTHWEST}

SOUTHEAST

FEET B

INFILTRATION

B'

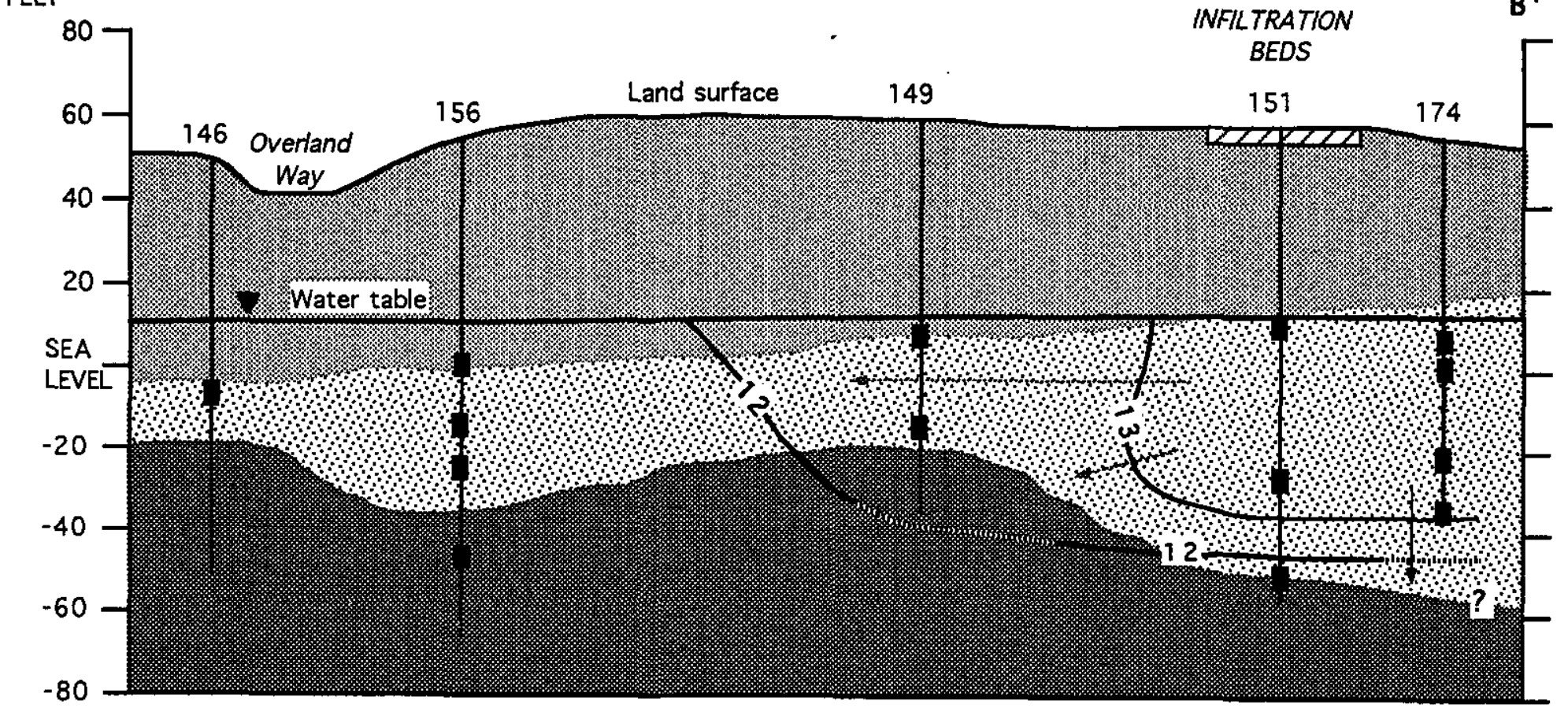

B.

VERTICAL EXAGGERATTON X2.5

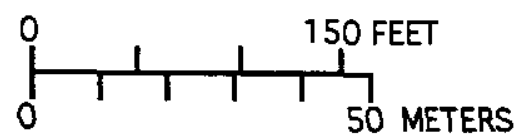

Figure 3. Lithologic units, potentiometric contours, and general direction of ground-water flow along $(A)$ section $A-A^{\prime}$ and $(B)$ section $B-B^{\prime}$ in the study area, December 1992-Continued. 


\section{Hydraulic Properties of Sediments}

The horizontal hydraulic conductivity of glacial outwash deposits on Cape Cod, as determined from aquifer-test analyses, ranges from about $150 \mathrm{ft} / \mathrm{d}$ for fine sand to $380 \mathrm{ft} / \mathrm{d}$ for coarse sand and gravel (Palmer, 1977; LeBlanc and others, 1986, 1988; Barlow and Hess, 1993; and Barlow, 1994). These references also indicate that the ratio of horizontal to vertical hydraulic conductivity for all sediments except fine sand generally is less than 10 to 1 . Ratios of about 30 to 1 and 50 to 1 were reported for fine sand by Barlow and Hess (1993) and Barlow (1994). The hydraulic conductivity of lacustrine sediments is much lower; horizontal and vertical hydraulic conductivities of $10^{-4}$ to $10^{-3} \mathrm{ft} / \mathrm{d}$ were reported for lacustrine silt and clay sediments from a location about $7 \mathrm{mi}$ from the study area (Barlow, 1994).

Hydraulic conductivity of aquifer sediments in the study area was estimated from particle-size data by methods of Hazen (1893) and Krumbein and Monk (1943). These methods relate hydraulic conductivity to characteristics of particle-size distribution through empirical equations. Results of the two methods were similar except for very coarse-grained sediments, where the Hazen method yielded much lower hydraulic conductivities than did the Krumbein and Monk method (table 1), possibly because the Hazen method is based entirely on the 10th percentile particle size. The Hazen method, therefore, is sensitive to small amounts of finegrained material; even very coarse-grained sediments from the study area contained about 3 percent silt and clay. The hydraulic conductivity of sediments from the three lithologic units calculated by the methods of Krumbein and Monk (1943) and Hazen (1893) averaged 9.4 and $7.9 \mathrm{ft} / \mathrm{d}$, respectively, for the upper fine-grained unit $(n=26), 130$ and $194 \mathrm{ft} / \mathrm{d}$, respectively, for the intermediate coarse-grained unit $(n=40)$, and 12 and $13 \mathrm{ft} / \mathrm{d}$, respectively, for the lower fine-grained unit $(\mathrm{n}=22)$ (table 1). Thus, although some sediment types were found in all three units, there were large differences in permeability among the units (table 1).

Horizontal hydraulic conductivity also was estimated in the present study from slug tests performed in several wells. Slug-test data were analyzed using the method of Bouwer and Rice (1976). Slug tests in wells screened in coarse-grained sediments were unreliable because of irregular water-level recovery and the rapid response to the initial displacement of water in the well.
Horizontal hydraulic conductivity estimated from slug tests was 10 and $59 \mathrm{ft} / \mathrm{d}$ for wells screened in fine to medium sand, $14 \mathrm{ft} / \mathrm{d}$ for a well screened in very fine to very coarse sand, $7 \mathrm{ft} / \mathrm{d}$ for a well screened in medium to very fine sand, and 4 and $6 \mathrm{ft} / \mathrm{d}$ for wells screened in fine to very fine sand and silt. These hydraulic conductivities are similar to those estimated on the basis of the particle-size distribution of fine-grained sediments (table 1).

Hydraulic conductivity estimated from particlesize distributions in the present study show large variation and generally were lower than hydraulic conductivities calculated from aquifer tests in outwash sediments on Cape Cod. Aquifer sediments in the study area are more heterogeneous and contain greater quantities of fine-grained material than do the more distal outwash plain deposits, for which many of the reported hydraulic conductivities were calculated. Also, hydraulic conductivity calculated from particle-size distributions reflects the variation of individual depositional layers; horizontal hydraulic conductivities calculated from aquifer tests generally represent the average horizontal hydraulic conductivities of all the lithologies present. Finally, the Krumbein and Monk and Hazen equations relate particle-size distribution to hydraulic conductivity measured by permeameter experiments using repacked sediment cores; such hydraulic conductivities may be lower than hydraulic conductivities derived from field methods, because the repacking eliminates aquifer anisotropy (Wolf and others, 1991; Millham and Howes, 1995).

Porosity of the stratified glacial outwash deposits of Cape Cod, estimated from ground-water tracer experiments conducted in Falmouth, ranges from 0.38 to 0.43 (Barlow, 1987; LeBlanc and others, 1988; Garabedian and others, 1991). Although these tracer tests are the only source of information for porosity of glacial-drift deposits of Cape Cod, the estimates are consistent with those reported for similar outwash deposits in other areas. Morris and Johnson (1967) reported a mean porosity for "water-laid" stratified deposits of 0.46 for silt, 0.43 for fine-grained sand, and 0.39 for medium and coarse-grained sand. The authors also reported a mean of 0.39 for "washed drift" (outwash) sand, and 0.44 for outwash silt. Perlmutter and Liever (1970) reported a porosity range of 0.34 to 0.38 for sand and gravel deposits of Long Island, New York. 
Porosity of aquifer core sediments collected from the study area, measured using gravimetric methods, averaged $0.34 \pm 0.07$ ( \pm one standard deviation, $n=230$ ). The difference between these porosities and those estimated from the tracer test studies cited above most likely results from settling of the core sediments during sample collection and transport. Standing water was always observed at the top of the sediment column within the sealed core liner, which probably originated as displaced pore water. Such redistribution of sediments and pore water within the core liner would reduce the porosity of the sediment column. Comparison of laboratory-measured aquifer properties of core samples from the Falmouth site (collected with the same wireline-piston core barrel used here) with field values by Wolf (1988) and Wolf and others (1991) indicated that porosity decreased from 0.39 to $0.31-0.32$ during sampling. The authors suggest that the decrease in porosity probably resulted from disturbance of ambient packing and destruction of zones of high porosity through mixing-in of finer material during coring. Porosity measured in the present study was similar to values measured by Wolf (1988) and Wolf and others (1991). Therefore, a porosity of 0.39 , as determined by Garabedian and others (1991) from a tracer test at the Falmouth site, was used in the present study in calculations and analyses that required a porosity value representing field conditions.

Bulk density measured in aquifer-core sediments, $1.9 \mathrm{~g} / \mathrm{cm}^{3}(\mathrm{n}=239)$, also likely reflected compaction. Therefore, a bulk density value of $1.6 \mathrm{~g} / \mathrm{cm}^{3}$ was used to convert weight-per-weight units to weight-per-volume units. This value is based on literature sources (Morris and Johnson, 1967; Marshall and Holmes, 1979) and the bulk density measured in subsurface infiltration-bed sediments (median $=1.63 \mathrm{~g} / \mathrm{cm}^{3}, \mathrm{n}=65$ ), which were less likely to be compacted than the saturated aquifer samples.

\section{Hydrology}

Ground water on Cape Cod occurs in six flow systems that are hydraulically independent under natural recharge and discharge conditions (LeBlanc and others, 1986). The septage-treatment facility is near the northern discharge boundary of one of these flow systems, which extends about $86 \mathrm{mi}^{2}$ south and west of the facility site (Masterson and Barlow, 1994). Precipitation recharge, the primary source of groundwater recharge on Cape Cod, is about 45 percent of mean annual precipitation or about $17 \mathrm{in} / \mathrm{yr}$ (LeBlanc and others, 1986).

Mean annual water-level fluctuations in the study area range from 1 to $2 \mathrm{ft}$, as determined from three nearby USGS wells with periods of record of 27 years (BMW 21) and 17 years (OSW 25 and OSW 22; see fig. 1). The magnitude of seasonal water-level fluctuations decreases near the coast where water levels are largely controlled by sea level (for example, OSW 133, fig. 4). Water-level fluctuations increase as the altitude of the water table increases farther inland (for example, OSW 25 and OSW 120, fig. 3). Water levels at OSW 25 during the present study (August 1989 to December 1992) correlated well with water levels at site 120 , at the inland end of the observation-well network and outside of the influence of the treatment-facility discharge $\left(R^{2}=0.98\right.$ and 0.90 for the two wells at the site; $\mathrm{n}=30$ ). Fluctuations of water levels in wells near the infiltration beds (OSW 90 and OSW 107, fig. 3) were greater than those in the inland wells, probably because of the treatment-facility discharge. Water levels during the present study generally were lower than those of average conditions, as represented by the mean water level of well OSW 25 during 1975-92 (fig. 3).

Ground-water levels and the direction of groundwater flow in the study area are affected by the regionalflow system, local surface-water boundaries, recharge rates, and aquifer lithology. The general configuration of the water table in December 1992 (fig. 5), after about 3 years of effluent discharge, is similar to pre-discharge conditions except for a steepening of gradient near the infiltration beds. Water-level altitudes in the study area are about 8 to $15 \mathrm{ft}$ above sea level. The direction of flow is from east to west and northwest from the interior of Cape Cod toward aquifer discharge boundaries at Namskaket Marsh (fig. 5) and Cape Cod Bay (figs. 1 and 2). There is an area of ground-water mounding below the northwestern or downgradient end of the infiltration beds, which also was present prior to initiation of effluent discharge. The mounding results from the shallow depth of the lower fine-grained lithologic unit beneath the northwestern end of the infiltration beds. The top of this unit is closest to land surface and to the water table in this area (fig. $3 A$ ). 


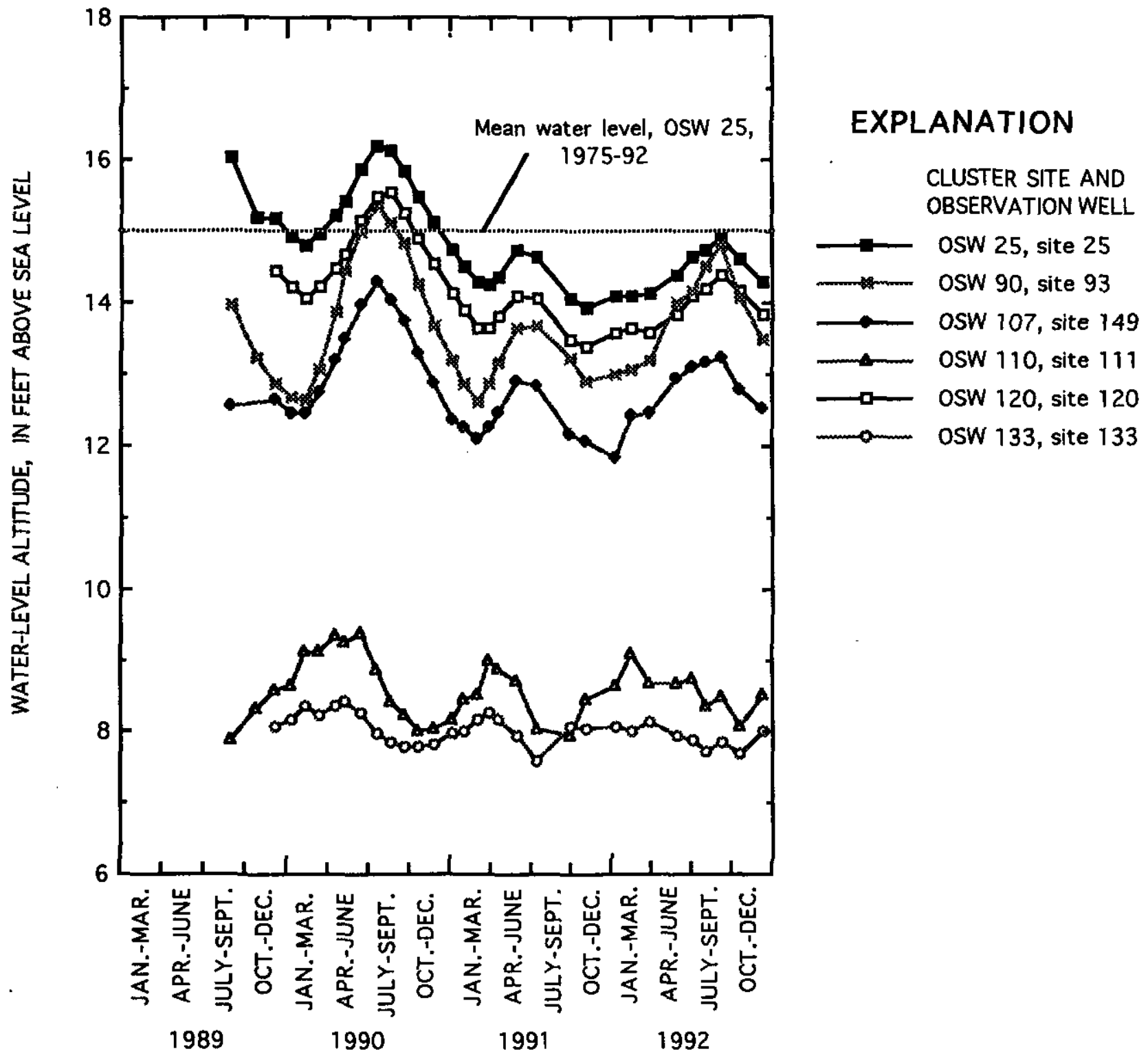

Figure 4. Water-level fluctuations in the study area, August 1989 through December 1992.

There are steep vertical potentiometric gradients in the study area that were present prior to and after initiation of effluent discharge. Immediately beneath and within $250 \mathrm{ft}$ downgradient of the infiltration beds, downward gradients as high as $0.033 \mathrm{ft} / \mathrm{ft}$ were measured within the fine-grained deposits. These gradients are significantly higher than vertical gradients of about $0.001 \mathrm{ft} / \mathrm{ft}$ that are typical for recharge areas of Cape Cod underlain by sand and gravel (Barlow, 1994). Lower hydraulic conductivities in the fine-grained unit, compared to those in the overlying coarse deposits, cause nearly horizontal equipotentials (indicating essentially vertical flow) in the fine-grained deposits. Ground water in the coarse-grained unit also flows downward in the westward direction of flow from the infiltration beds, where the top of the coarse-grained unit slopes downward (fig. 3A). Ground-water flow is more nearly horizontal downgradient from the infiltration beds in the northwestward direction (fig. 3B). Upward vertical gradients are present near Namskaket Marsh (for example, at site 111 , fig. $3 A$ ). These upward gradients likely are the result of proximity to the regional ground-water discharge area. 


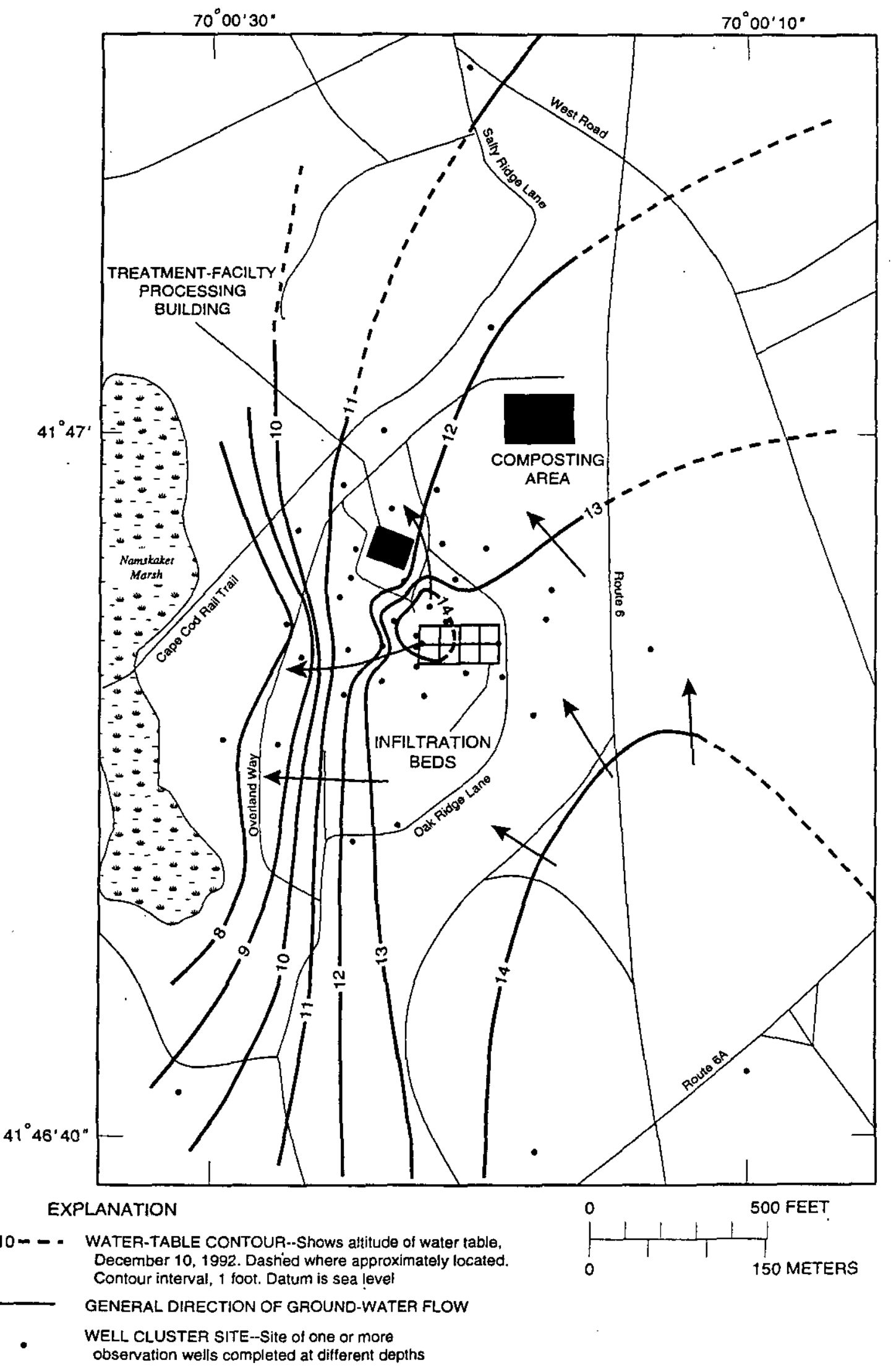

Figure 5. Altitude of the water table and general direction of ground-water flow in the study area. December 1992. 


\section{Ground-Water Quality Prior to Effluent Discharge}

Ambient (background) ground water in the study area, sampled prior to effluent discharge, is slightly acidic and contains low concentrations of dissolved solids (table 3). These characteristics are typical of unconsolidated glacial aquifers derived from igneous or metamorphic source rocks (Freeze and Cherry, 1979). Concentrations of calcium, magnesium, sodium, potassium, bicarbonate (as alkalinity), sulfate, and chloride (table 3) are similar to concentrations measured in uncontaminated ground water throughout Cape Cod (Frimpter and Gay, 1979). Sodium and chloride, the dominant ions, likely result from sea spray and(or) road-deicing salt.

Table 3. Physical properties and concentrations of major chemical constituents, nutrients, and selected trace constituents in ambient (background) ground water in the study area prior to effluent discharge, September 1989

[Summary statistics based on 29 samples. Interquartile range equal to the difference between 25 th and 75 th percentiles. Median and interquartile range for constituents in concentrations less than the analytical detection limits were estimated using the robust probability method for censored data of Helsel and Cohn (1988) and Helsel (1990). <, actual value is less than value shown. $\mu \mathrm{S} / \mathrm{cm}$, microsiemen per centimeter at $25^{\circ} \mathrm{C} ;{ }^{\circ} \mathrm{C}$, degree Celsius; $\mathrm{mg} / \mathrm{L}$, milligram per liter; $\mu \mathrm{g} / \mathrm{L}$, microgram per liter. --, no data]

\begin{tabular}{|c|c|c|c|c|}
\hline Properties and constituents & Minimum & Median & Maximum & $\begin{array}{c}\text { Interquartile } \\
\text { range }\end{array}$ \\
\hline \multicolumn{5}{|l|}{ Physical properties } \\
\hline Specific conductance $(\mu \mathrm{S} / \mathrm{cm})$ & 75. & 122 & 304 & 49 \\
\hline pH (standard units) & 5.6 & 6.3 & 7.5 & .02 \\
\hline Temperature, water $\left({ }^{\circ} \mathrm{C}\right)$ & 9.2 & 10.1 & 11.6 & 1.0 \\
\hline Oxygen, dissolved $(\mathrm{mg} / \mathrm{L})$ & .1 & 6.8 & 10.9 & 8.1 \\
\hline 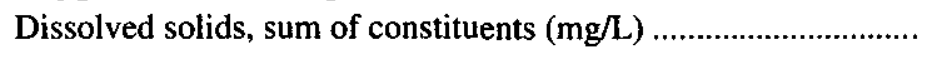 & 44 & 70 & 170 & 30 \\
\hline \multicolumn{5}{|l|}{ Major chemical constituents (mg/L) } \\
\hline 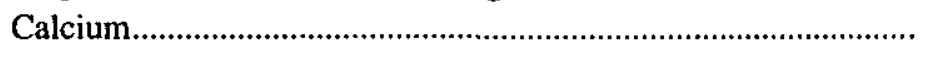 & 1.7 & 3.4 & 14.0 & 2.9 \\
\hline Magnesium & 1.3 & 2.2 & 8.0 & 1.6 \\
\hline Sodium & 10.0 & 15.0 & 23.0 & 3.5 \\
\hline Potassium & .6 & 1.2 & 2.0 & 6 \\
\hline Alkalinity, total (as $\left.\mathrm{CaCO}_{3}\right)$ & 5.0 & 11.0 & 33.0 & 4.0 \\
\hline Sulfate & 2.0 & 6.0 & 40.0 & 6.0 \\
\hline Chloride & 12.0 & 21.0 & 77.0 & 6.5 \\
\hline Silica & 8.3 & .13 .0 & 24.0 & 6.0 \\
\hline \multicolumn{5}{|l|}{ Nutrients $(\mathbf{m g} / \mathbf{L})$} \\
\hline 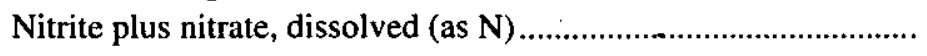 & $<.10$ & .07 & 3.40 & .90 \\
\hline Nitrogen, ammonium, dissolved (as $\mathrm{N}) \ldots \ldots \ldots$ & $<.01$ & .02 & .37 & .06 \\
\hline Nitrogen, dissolved, ammonium plus organic (as $\mathrm{N}$ ) ....................... & $<.20$ & .07 & .60 & .27 \\
\hline Phosphorus, dissolved (as $\mathrm{P})^{1}$ & $<.01$ & .02 & .60 & .04 \\
\hline 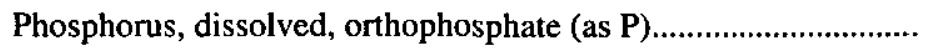 & $<.01$ & .02 & .12 & .04 \\
\hline \multicolumn{5}{|l|}{ Trace constituents $(\mu \mathrm{g} / \mathrm{L})$} \\
\hline Boron & $<10$ & 20 & 110 & 15 \\
\hline Iron & 3 & 14 & 9,000 & 500 \\
\hline 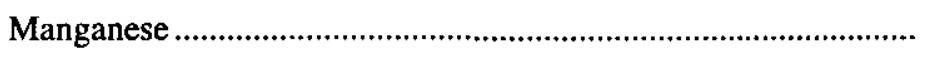 & 2 & 54 & 270 & 98 \\
\hline \multicolumn{5}{|l|}{ Organic carbon $(\mathbf{m g} / \mathbf{L})$} \\
\hline Carbon, organic, dissolved (as C) & .2 & .4 & .7 & .3 \\
\hline
\end{tabular}


Dissolved-oxygen concentrations in ambient ground water range from near saturation to nearly zero (table 3). The highest concentrations (10 to $11 \mathrm{mg} / \mathrm{L}$ ) were measured in ground water from shallow wells and wells screened in coarse-grained material. Low concentrations ( 0 to $0.1 \mathrm{mg} / \mathrm{L}$ ) were measured in ground water from wells screened at depths greater than $80 \mathrm{ft}$ below the water table. Reduced material such as organic matter or pyrite, which would rapidly deplete dissolved oxygen, generally was not found in study-area sediments (L.J. Poppe and A.M. Moffett, U.S. Geological Survey, written commun., December 1990). Thus, the low concentrations of dissolved oxygen probably result from a long ground-water residence time in the aquifer, such as found by LeBlanc (1984) for fine-grained sediments near Falmouth, Cape Cod.

Iron and manganese concentrations also varied greatly in the aquifer (table 3) and were related to concentrations of dissolved oxygen. Iron and manganese are relatively insoluble in oxygenated water at the $\mathrm{pH}$ of ambient ground water. Iron and manganese oxides and oxyhydroxides are likely to be present in the aquifer matrix as weathering-product minerals and coatings on sand grains (Postma and Brockenhuus-Schack, 1987). In fact, reddish-orange iron oxide or oxyhydroxide staining on some coarse-grained aquifer sediments was noted during drilling, particularly on coarse-grained sediments in close vertical contact with fine-grained sediments. Iron oxides and hydroxides (limonite) were common accessory minerals in outwash deposits in Falmouth, Cape Cod (Barber, 1990). These compounds are dissolved under moderately reducing (low dissolved oxygen) conditions (Hem, 1967, 1972). High iron $(1,200$ to $9,000 \mu \mathrm{g} / \mathrm{L})$ and manganese $(68$ to $270 \mu \mathrm{g} / \mathrm{L})$ concentrations coincided with low dissolved-oxygen concentrations (less than 0.1 to $3.3 \mathrm{mg} / \mathrm{L}$ ).

Concentrations of nitrogen and phosphorus species in the aquifer were low under natural conditions and comparable with typical concentrations reported by Frimpter and Gay (1979) for ground water on Cape Cod. Median concentrations of all nitrogen species were less than $0.10 \mathrm{mg} / \mathrm{L}$ as $\mathrm{N}$, and the median phosphorus concentration, present as orthosphosphate, was 0.02 $\mathrm{mg} / \mathrm{L}$. Concentrations of organic carbon were uniformly low, ranging from 0.2 to $0.7 \mathrm{mg} / \mathrm{L}$. Concentrations of nitrite plus nitrate greater than $0.5 \mathrm{mg} / \mathrm{L}$ as $\mathrm{N}$ measured in the study area probably reflect anthropogenic inputs, as septic-tank effluent or fertilizer, from residential areas upgradient of the site.

\section{OPERATION OF THE SEPTAGE-TREATMENT FACILITY AND EFFLUENT QUALITY}

The Tri-Town Septage-Treatment Facility receives septage from the towns of Brewster, Eastham, and Orleans and lesser quantities from Truro, Wellfleet, and Provincetown (fig. 1). The septage is conditioned with ferric chloride and calcium hydroxide (lime) and separated into solid and liquid components with a high-pressure filter press. The solid component is disposed of offsite, while the liquid component receives secondarylevel treatment. Hydrochloric acid is added for $\mathrm{pH}$ control, and phosphoric acid is added as a nutrient base. The liquid then passes through rotating biological contactors to reduce biological oxygen demand. Finally, it is disinfected with ultraviolet irradiation. The final effluent is discharged one to two times per day to sand-lined infiltration beds (figs. 2 and 3). Effluent discharge to the eight infiltration beds is rotated on an irregular basis. The beds are 35 by $35 \mathrm{ft}$ each in dimension, about $5 \mathrm{ft}$ deep, and were originally excavated in native material. The surficial 0.5- to 1-foot of sediment was removed in the spring of 1992 and replaced with clean, coarse sand to increase permeability.

The facility was designed to discharge 45,000 $\mathrm{gal} / \mathrm{d}$. However, actual discharge rates rarely reached design capacity prior to the summer of 1992 . Mean daily effluent discharge for the entire period of study was $19,000 \mathrm{gal} / \mathrm{d}$. Discharge rates (fig. 6) varied seasonally, with peak rates occurring during the summer months, when the population on Cape Cod substantially increases. Mean daily discharge during the summer months of June, July, and August $(25,100 \mathrm{gal} / \mathrm{d})$ was more than twice the mean daily discharge during the winter months of December, January, and February (11,500 gal/d) during 1990-92.

The effluent was typically high in dissolved solids (median equal to $1,690 \mathrm{mg} / \mathrm{L}$ ) and had a high specific conductance (median equal to $3,330 \mu \mathrm{S} / \mathrm{cm}$; table 4). The major chemical constituents were chloride (median equal to $950 \mathrm{mg} / \mathrm{L}$ ) and calcium (median equal to 440 $\mathrm{mg} / \mathrm{L}$ ), which were additives in the treatment process. 

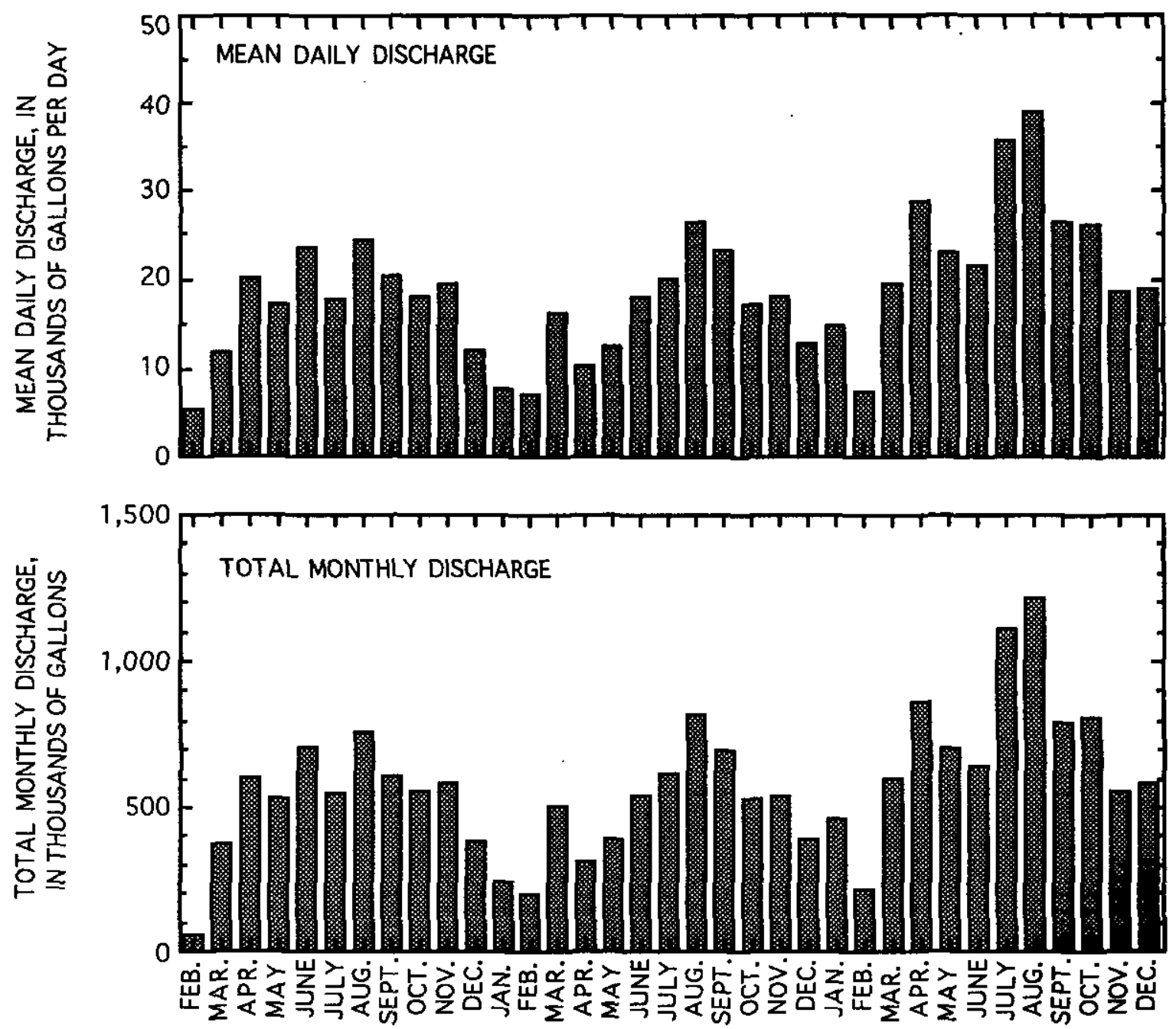

1990

1991

1992

Figure 6. Mean daily discharge and total monthly discharge of effluent, February 1990 through December 1992.

Sodium was present in lower concentrations, and potassium and sulfate were minor constituents. Concentrations of the individual ions were quite variable, with interquartile ranges of 17 to 140 percent of median concentrations. The effluent also contained significant alkalinity (median equal to $110 \mathrm{mg} / \mathrm{L}$ as calcium carbonate). $\mathrm{pH}$, closely controlled in the treatment process, was consistently near neutral (median equal to 7.2 , interquartile range $=0.4$ ).

The median concentration of total dissolved nitrogen (sum of nitrate-, nitrite-, and ammonium-nitrogen, and dissolved organic nitrogen) was $44 \mathrm{mg} / \mathrm{L}$ as $\mathrm{N}$ (table 4). Variability in total dissolved nitrogen (interquartile range $=12$, or 27 percent of the median) was low compared to that of the major ions. Concentrations of individual dissolved-nitrogen species, however, were highly variable (interquartile range $=130$ to 320 percent of the medians). The dominant form of nitrogen varied seasonally in that ammonium was the primary form in January and February. During the rest of the year, there was no apparent pattern in occurrence of reduced or oxidized forms. Variation in the dominant nitrogen form resulted from the extent to which nitrification, the oxidation of ammonium to nitrate, occurred during treatment.

Concentrations of total (dissolved plus particulate) organic nitrogen exceeded concentrations of dissolved organic nitrogen in the 15 samples in which both measurements were made. The difference was statistically 
Table 4. Physical properties and concentrations of major chemical constifuents, nutrients, and boron in effluent, March 1990 through December 1992

[Summary statistics based on 45 samples, unless otherwise noted. Interquartile range equal to the difference between 25 th and 75th percentiles. Median and interquartile range of constituents in concentrations less than the analytical detection limits were estimated using the robust probability method for censored data of Helsel and Cohn (1988) and Helsel (1990). $\mu \mathrm{S} / \mathrm{cm}$, microsiemen per centimeter at 25 degrees Celsius; $\mathrm{mg} / \mathrm{L}$, milligram per liter; $\mu \mathrm{g} / \mathrm{L}$, microgram per liter. --, no data]

Properties and constituents $\quad$ Median $\quad$ Interquartile range

Interquartile range divided by the median, multiplied by 100

\section{Physical properties}

Specific conductance $(\mu \mathrm{S} / \mathrm{cm})$.

3,330

7.2

1,100

33

$\mathrm{pH}$ (standard units)

1,690

.4

6

Dissolved solids, sum of constituents ( $\mathrm{mg} / \mathrm{L}$ )

530

31

\section{Major constituents (mg/L)}

Calcium

440

Magnesium ${ }^{1}$

Sodium.

.8

100

30

110

19

950

1.1

Chloride

Silica

\section{Nutrients (mg/L)}

Nitrate, dissolved (as N)

Nitrite, dissolved (as N) ${ }^{1}$

$$
9.4
$$

.76

Nitrogen, ammonium, dissolved (as $\mathrm{N}$ )

Nitrogen, organic, ${ }^{2}$ total (as $\left.\mathrm{N}\right)^{3}$.

27

7.2

4.0

Nitrogen, organic, ${ }^{2}$ dissogen, total (as N)

Nitrogen, total, dissolved (as $\mathrm{N}$ )

Phosphorus, total (as P)

Phosphorus, dissolved (as P) ${ }^{1}$

Phosphorus, dissolved, orthophosphate (as P) ${ }^{1}$

\section{Trace constituents $(\mu \mathrm{g} / \mathrm{L})$}

Boron

\section{Organic carbon (mg/L)}

Carbon, organic, total (as C) ${ }^{2}$

Carbon, organic, dissolved (as C)

${ }^{1}$ Analyses include detections less than analytical detection limits.

${ }^{2}$ Organic nitrogen calculated as the difference between separate analyses of ammonium plus organic nitrogen and ammonium nitrogen.

3

${ }^{3}$ Median total concentration (dissolved plus particulate) in samples from March 1990 through December 1992 estimated using median ratio of total to dissolved concentration in 15 samples collected March through December 1992. 
significant based on results of the Wilcoxon signed-rank test $(p=0.007)$. The median ratio of total to dissolved organic nitrogen was 1.8 . Thus, particulate organic nitrogen was a large fraction of the total organic nitrogen but less than 10 percent of the total nitrogen in the effluent. Concentrations of total nitrogen (sum of nitrate-, nitrite-, and ammonium-nitrogen, dissolved organic nitrogen, and particulate organic nitrogen) estimated from dissolved concentrations using this ratio had a median concentration of $46 \mathrm{mg} / \mathrm{L}$ as $\mathrm{N}$ (table 4 ).

Concentrations of dissolved organic carbon moderately varied (interquartile range $=57$ percent of the median) with a median of $14 \mathrm{mg} / \mathrm{L}$. As with organic nitrogen, concentrations of total organic carbon were larger than dissolved concentrations. The median ratio of total to dissolved organic carbon in the 15 samples in which both measurements were made (1.7) indicated that about two-fifths of the organic carbon in effluent was in the particulate form. Concentrations of total organic carbon were estimated from dissolved concentrations using this ratio and had a median of $24 \mathrm{mg} / \mathrm{L}$ (table 4).

\section{CHANGES IN EFFLUENT QUALITY IN THE UNSATURATED ZONE .}

Physical, chemical, and microbial processes affecting solute movement differ in the unsaturated and saturated zones; therefore, changes in effluent quality were investigated separately in each zone. The unsaturated zone beneath the infiltration beds is about $40 \mathrm{ft}$ thick and is composed of fine to medium sand with variable amounts of silt. These sediments represent a reservoir of sorbed ions and surfaces with which the effluent could interact through sorption and ion exchange. Microbial communities also transform effluent constituents, especially through aerobic biological processes. Detailed unsaturated-zone sampling to investigate these processes was beyond the scope of the present study. Therefore, transformations and attenuation of effluent constituents in the unsaturated zone were assessed by comparing effluent chemistry with ground-water chemistry at the water table beneath the infiltration beds.

\section{Changes Caused By Physical Processes}

Chloride concentrations in effluent and ground water from OSW 136 (at cluster site 150, fig. 2, henceforth referred to as "water-table ground water") were compared to identify effluent-quality changes due to physical processes (dilution) in the unsaturated zone. Chloride was used as a tracer of physical transport because it behaves conservatively in ground water (LeBlanc, 1984; Hem, 1985, p. 118). The comparison was complicated, however, by the variation in chloride concentrations in effluent with time (fig. $7 A$ ). Further, concentrations in effluent and water-table ground water were not statistically independent but were related through a time lag, theoretically equal to the unsaturated-zone traveltime. Therefore, the unsaturated-zone traveltime was estimated so that chloride concentrations in effluent and water-table ground water could be compared as paired data.

The unsaturated-zone traveltime was estimated as follows. Chloride concentrations in water-table ground water $\left(y_{t}\right)$ were correlated separately with data sets of time-lagged effluent concentrations, $\left(x_{t}\right),\left(x_{t-1}\right),\left(x_{t-2}\right), \ldots$, $\left(x_{t-n}\right)$, where $t$ is the order of the sample in time and $n$ is the maximum number of time lags expected to impact $y_{t}$. The nonperiodic data sets, spaced at semimonthly to monthly intervals, were transformed into equally spaced, monthly values using linear interpolation between data points (EXPAND procedure of the SAS/ETS module, SAS Institute, Inc., 1988, p. 261). The time-lags tested were $1,2,3,4,5$, and 6 months. Ground-water samples collected prior to January 1991 were not used because the concentrations steadily increased with time, reflecting initial arrival of effluent at the well (fig. 7A). Before correlation, the two transformed data sets were individually tested for serial correlation with the Durbin-Watson statistic, $d$ (Neter and others, 1985, p. 450). Because this test indicated that both data sets were serially correlated ( $d$ was significant at the $\alpha=0.05$ level), an auto-regressive model was used for the correlations. The error term of the regression in this procedure is assumed to be serially correlated (AUTOREG procedure of SAS/ETS, SAS Institute, Inc., 1988, p. 171). The strength of each correlation was then determined. 

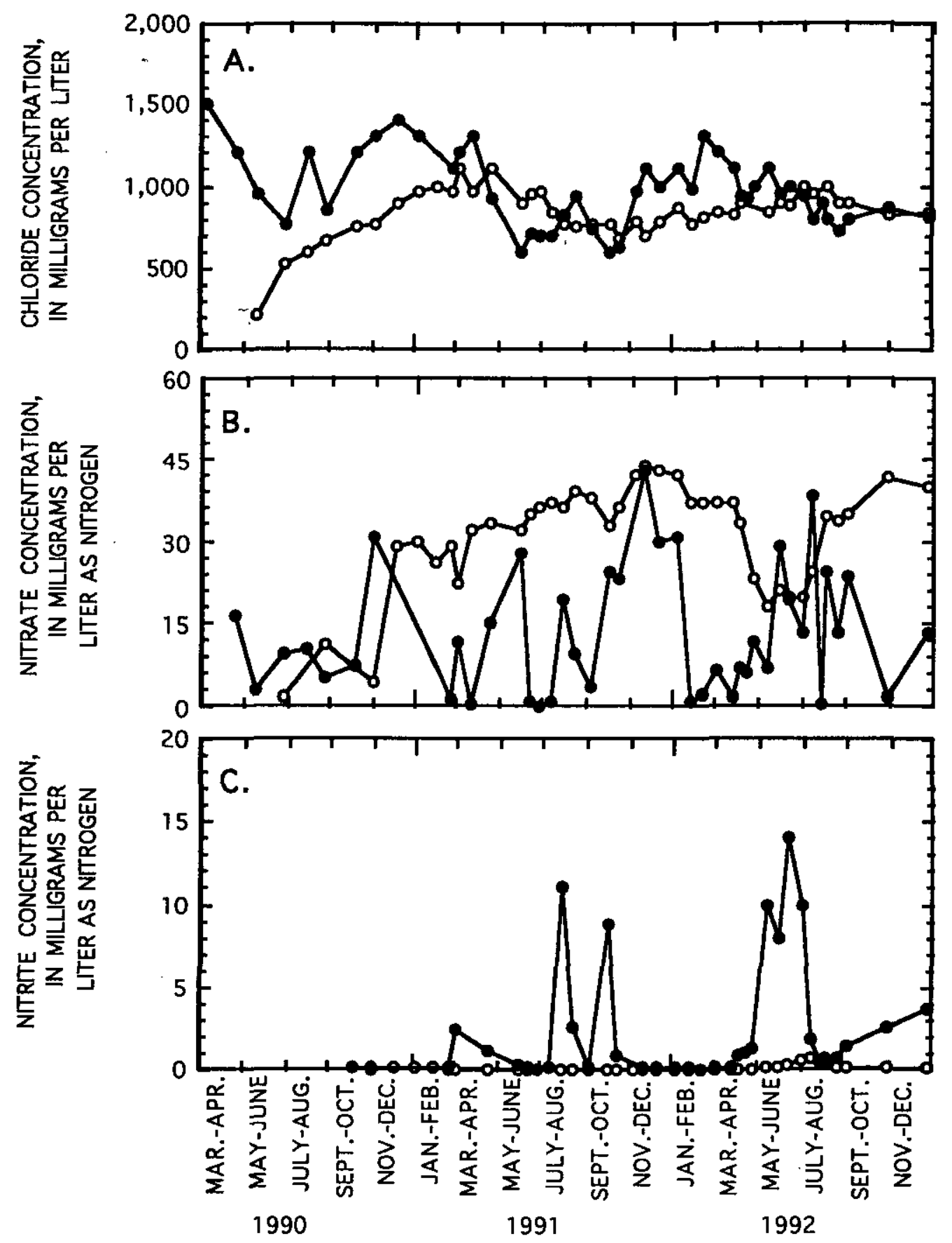

\section{EXPLANATION}

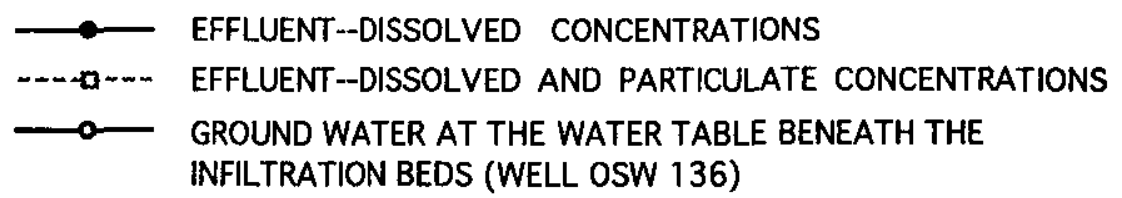

Figure 7. Concentrations of chloride and nitrogen species in effluent and watertable ground water beneath the infiltration beds (well OSW 136), March 1990 through December 1992. A. Chloride. B. Nitrate. C. Nitrite. D. Ammonium. E. Organic nitrogen. 

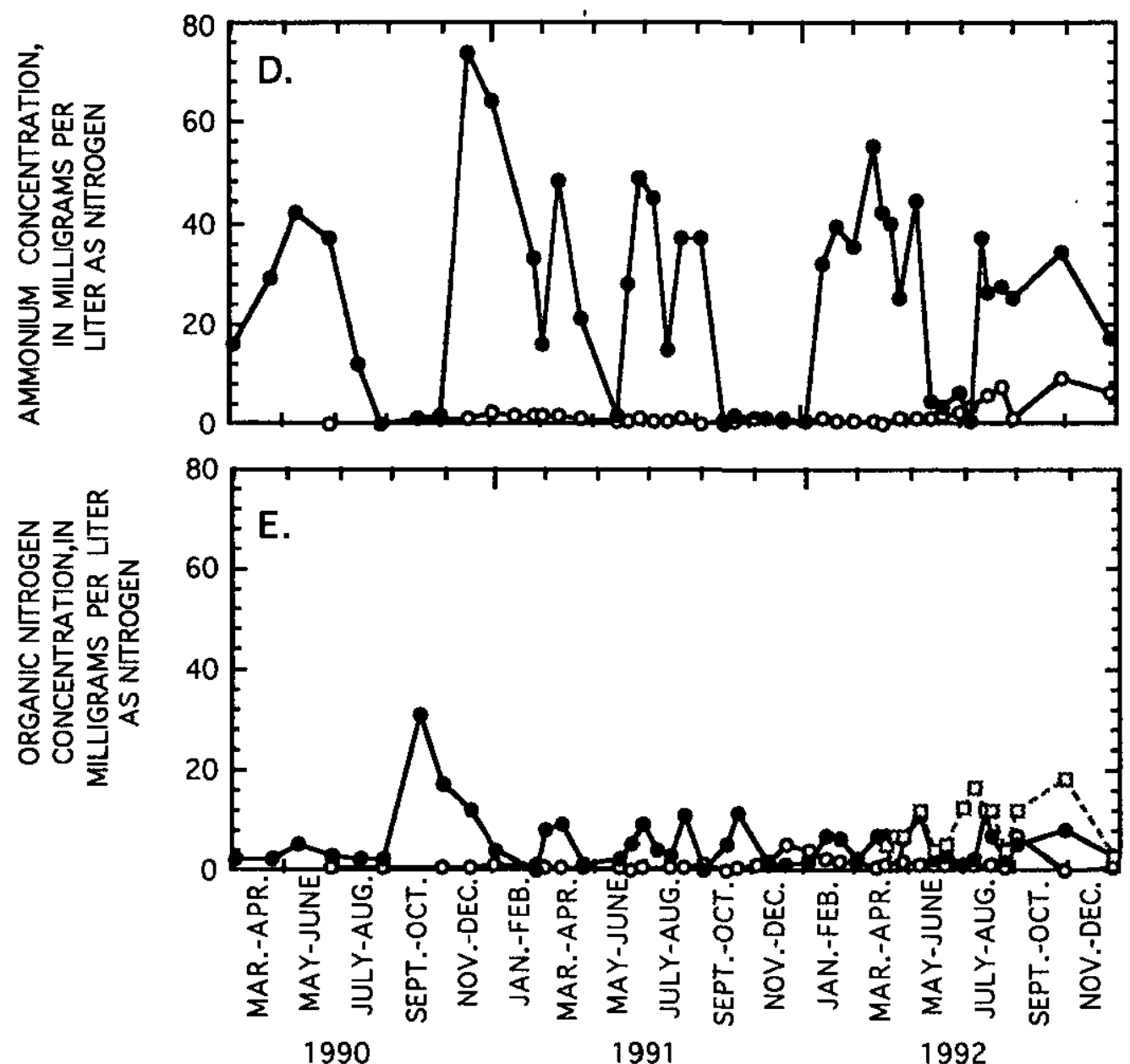

Figure 7. Concentrations of chloride and nitrogen species in effluent and watertable ground water beneath the infiltration beds (well OSW 136), March 1990 through December 1992-Continued.

The auto-regressive correlation indicated that chloride concentrations in effluent and in water-table ground water were related, with the maximum correlation at a lag of 3 months $\left(R^{2}=0.63\right)$, and a lesser correlation at a lag of 4 months $\left(R^{2}=0.47\right)$. The estimated 3-month traveltime from land surface to OSW 136 agrees with time-series measurements of specific conductance in ground water at the well. Specific conductance greater than background values was first measured in mid-May 1990, about 3 months after the beginning of effluent discharge. The effects of variable flow-paths distances and soil-moisture conditions on traveltime were averaged in the 3-month estimate. Dispersion, which is another source of variability in concentrations, also is not considered in the estimate. However, data were not available to evaluate these variations. The presence of a time-lagged correlation was assumed to imply that variations in traveltime and the effects of dispersion were small relative to the variation of chloride concentrations in effluent.

The chloride-correlation estimate of unsaturatedzone traveltime may be compared with traveltimes based on the effluent-loading rate and assumption of steady-state pore-water displacement (loading-rate method). Traveltimes based on the mean daily effluentloading rate $\left(19,000 \mathrm{gal} / \mathrm{d}\right.$ or $\left.2,540 \mathrm{ft}^{3} / \mathrm{d}\right)$, area of the eight infiltration beds $\left(9,800 \mathrm{ft}^{2}\right)$, and a specific yield range of 0.15 to 0.30 (Morris and Johnson, 1967; Guswa and LeBlanc, 1985) were 22 to 43 days, which was lower than the chloride-correlation estimate. However, the loading-rate method likely underestimates the unsaturated-zone traveltime because the method 
assumes vertical flow. Lateral flow in response to capillary pressure gradients during and between the intermittent effluent discharge is likely to have occurred (Yeh and others, 1985). Lateral flow also may have occurred during temporary saturation caused by low-permeability layers (Hillel, 1980, p. 215). Because of lateral flow, effluent would percolate through a larger volume of sediment than that directly overlain by the individual beds, thereby increasing the unsaturated-zone traveltime. Lateral flow was detected in the unsaturated zone during infiltration experiments in outwash sediments in Falmouth, Cape Cod (Rudolph and others, 1993; Stevens, 1994).

Comparison of chloride concentrations in watertable ground water from January 1991 through December 1992, with concentrations in effluent indicates that constituent concentrations in water-table ground water throughout this period were slightly diluted. The two sets of concentrations were compared by applying the Wilcoxon signed-rank test to paired monthly values, offset by 3 months. The test indicated that the chloride concentrations in effluent and water-table ground water were significantly different $(p=0.0017)$. The median difference determined in this test was $130 \mathrm{mg} / \mathrm{L}$, with a 95 percent confidence interval of 56 to $180 \mathrm{mg} / \mathrm{L}$ (table 5). These values correspond to a decrease of 14 percent from effluent concentrations (based on the median monthly chloride concentration in effluent), and the 95percent confidence interval corresponds to a range of 5.9 to 19 percent. This difference is inferred to result from dilution.

The 14-percent dilution is greater than expected from precipitation recharge. Precipitation recharge is estimated as 18.7 and 18.6 in. for 1991 and 1992 , respectively. These values are based on annual precipitation of 41.7 and $41.4 \mathrm{in}$. measured in the nearby town of Chatham (Kathryn Vreeland, Northeast Regional Climate Center, Ithaca, N.Y., oral commun., 1994) and the 45-percent recharge estimate of LeBlanc and others (1986). Precipitation recharge corresponds to 4 and 3 percent of the effluent recharge in 1991 and 1992, respectively, assuming uniform application of effluent over the infiltration-bed area. Thus, precipitation could account for a significant fraction, but still less than one-half, of the dilution in chloride concentrations in water-table ground water. Mixing of effluent with ambient ground water from upgradient of the infiltration beds must account for the remaining dilution. The paired differences between chloride concentrations in effluent and water-table ground water (monthly concentrations) decreased with time $(p=0.035$, Wilcoxon Signed-Rank test), which suggests that dilution was decreasing. Decreased dilution is expected as the areal extent of the septage-effluent plume increased in all directions beneath the infiltration beds with time.

\section{Changes Caused by Reactive Processes}

Changes in effluent quality caused by reactive processes in the unsaturated zone were identified, as with chloride, by comparing constituent concentrations in effluent and water-table ground water. Concentrations were compared by applying the Wilcoxon signed-rank test for paired data to lagged monthly values as described previously. Differences in concentrations between effluent and water-table ground water greater or less than that found in chloride concentrations were then inferred to result from biological or chemical reactive processes.

A decrease in total nitrogen concentrations from reactive processes could not be identified from concentrations in effluent and water-table ground water; however, the distribution of nitrogen species changed substantially in the unsaturated zone. Ammonium and organic nitrogen composed about 70 percent of the total dissolved nitrogen in the effluent, with ammonium predominating (figs. $7 D$ and $E$ ). In contrast, about 90 percent of the total dissolved nitrogen in water-table ground water was in the form of nitrate (fig. $7 B$ ). Organic nitrogen in effluent was mineralized to ammonium and ammonium in effluent was nitrified to nitrate in the unsaturated zone. The small amount of nitrite in the effluent (fig. $7 \mathrm{C}$ ) also was oxidized to nitrate. Concentrations of total dissolved nitrogen in water-table ground water, with a median of $37 \mathrm{mg} / \mathrm{L}$ as $\mathrm{N}$, were significantly less $(p=0.0119)$ than dissolved concentrations in effluent (table 5). The median difference, $8.5 \mathrm{mg} / \mathrm{L}$ as $\mathrm{N}$ or 19 percent of the effluent median, is greater than expected from dilution alone. However, the 95-percent confidence interval around this median difference (3.6 to 39 percent) overlaps with the range determined for chloride concentrations and so could not be distinguished from dilution. The fate of the particulate organic nitrogen also could not be evaluated in this analysis (particulate nitrogen is discussed in the section, "Summary of Reactive Processes Involving Nitrogen and Nitrogen Budget"). 
Table 5. Physical properties and concentrations of major chemical constituents, nutrients, and boron in water-table ground water beneath the infiltration beds, January 1991 through December 1992, and comparison with physical properties and chemical concentrations in effluent

[Summary statistics based on 35 samples. Median values for constituents in concentrations less than the analytical detection limits were estimated using the robust probability method for censored data of Helsel and Cohn (1988) and Helsel (1990). The Wilcoxon signed rank test was used to differentiate between concentrations in effluent and water-table ground water (median difference and 95-percent confidence interval, Minitab 7.2, Ryan and others, 1985, p. 289). The test was applied to monthly concentration values, which were obtained by linearly interpolating between data points (EXPAND procedure of SAS/ETS Module, SAS Institute, 1988, p. 261). Positive and negative differences indicate that concentrations in water-table ground water are greater than $(+)$ or less than $(-)$ concentrations in effluent. $\mu \mathrm{S} / \mathrm{cm}$, microsiemen per centimeter at 25 degrees Celsius; $\mathrm{mg} / \mathrm{L}$, milligram per liter; $\mu \mathrm{g} / \mathrm{L}$, microgram per liter. --, no data]

$\begin{array}{cc}\text { Median } \\ \text { Properties and constituents } & \begin{array}{c}\text { concentration in } \\ \text { water-table } \\ \text { ground water }\end{array}\end{array}$

(OSW 136)
Median difference in concentration between water-table ground water and effluent

\begin{tabular}{cc}
\hline Difference & $\begin{array}{c}95 \text {-percent } \\
\text { confidence } \\
\text { interval }\end{array}$ \\
\hline
\end{tabular}

\section{Physical properties}

Specific conductance $(\mu \mathrm{S} / \mathrm{cm})$

3,010

5.0

$-470$

-290 to -690

$\mathrm{pH}$ (standard units)

Major chemical constituents $(\mathrm{mg} / \mathrm{L}$ )

Calcium

Magnesium ${ }^{1}$.

Sodium.

Potassium

Alkalinity, total (as $\mathrm{CaCO}_{3}$ )

Sulfate.

Chloride

Silica

\section{Nutrients (mg/L)}

Nitrate, dissolved (as N)

Nitrite, dissolved (as $\mathrm{N})^{1}$

Nitrogen, ammonium, dissolved (as $\mathrm{N}$ ).

Nitrogen, organic, ${ }^{2}$ dissolved (as $\mathrm{N}$ )

Nitrogen, total, dissolved (as $\mathrm{N}$ )

Phosphorus, dissolved (as $\mathrm{P}$ ) ${ }^{1}$

Phosphorus, dissolved, orthophosphate (as P) ${ }^{1}$.
35

$\begin{array}{cc}330 & -120 \\ 44 & +50 \\ 100 & -9.1 \\ 16 & -14 \\ 1.2 & -- \\ 1.1 & -20 \\ 870 & -130 \\ 17 & +16\end{array}$

-75 to -160

+59 to +40

-1.4 to -18

-12 to -17

$-$

-16 to -24

-56 to -180 .

+15 to +16

$\begin{array}{ccc}35 & +20 & +15 \text { to }+26 \\ .04 & -- & -- \\ 1.0 & -23 & -13 \text { to }-32 \\ 1.0 & -4.0 & -2.1 \text { to }-6.5 \\ 37 & -8.5 & -1.6 \text { to }-17 \\ .02 & -- & -- \\ .02 & -- & --\end{array}$

140

$-60$

-40 to -80

Boron

${ }^{1}$ Analyses include detections less than analytical detection limits

${ }^{2}$ Organic nitrogen calculated as the difference between separate analyses of ammonium plus organic nitrogen and ammonium nitrogen. 
Nitrification generates acidity by releasing two hydrogen ions for every ammonium ion oxidized. The decrease in $\mathrm{pH}$ of about two standard units between effluent and water-table ground water (table 5) likely resulted at least partly from nitrification. A similar $\mathrm{pH}$ decrease associated with unsaturated-zone nitrification in on-site septic-system effluent was found by Robertson and others (1991) in a low-carbonate sandy aquifer. Nitrification-generated acidity and the consumption of inorganic carbon by nitrifiers also may explain the decrease in alkalinity, which was almost entirely depleted in the unsaturated zone (table 5). Finally, the acid conditions may have favored absorption of sulfate (Schlesinger, 1991, p. 172), also depleted in the unsaturated zone (table 5), although biological uptake is another likely explanation for this change.

Concentrations of total dissolved phosphorus and orthophosphate in water-table ground water generally were low (table 5) and similar to those of ambient ground water. Dissolved and particulate phosphorus in effluent was removed in the unsaturated zone. Phosphorus is highly reactive with soil minerals in oxic conditions, through precipitation and anion absorption, especially in the presence of iron and maganese oxyhydroxides (Hem, 1985, p. 128). Phosphorus may be mobile at a large time scale in anoxic conditions (Walter and Stollenwerk, 1994). Phosphorus removal in the unsaturated zone also occurs in septic-system effluent (Robertson and others, 1991; Weiskel and Howes, 1992).

Organic carbon concentrations decreased in the unsaturated zone from medians of $14 \mathrm{mg} / \mathrm{L}$ (dissolved) and $24 \mathrm{mg} / \mathrm{L}$ (total) in effluent to $1.8 \mathrm{mg} / \mathrm{L}$ in ground water at the water table beneath the infiltration bed (table 5). Organic carbon may have been removed through aerobic respiration, filtering of particulate organic material by soil particles, and sorption (especially for synthetic compounds, Barber 1990). Organic carbon consumption through aerobic respiration also may have contributed to the decreases in $\mathrm{pH}$ and alkalinity, through carbon dioxide production and oxidation of organic acids, respectively.

Cation exchange in the unsaturated zone altered the ionic composition of the effluent. Calcium concentrations decreased by about 28 percent, or about 14 percent more than attributable to dilution (table 5). In contrast, magnesium concentrations increased.
Magnesium concentrations in effluent generally were less than $1 \mathrm{mg} / \mathrm{L}$, but concentrations in water-table ground water were much higher. Magnesium concentrations in ground water decreased from a maximum of $120 \mathrm{mg} / \mathrm{L}$ in December 1990 to about 30 $\mathrm{mg} / \mathrm{L}$ by December 1992; the latter concentration is still an order of magnitude higher than that in ambient ground water $(2.2 \mathrm{mg} / \mathrm{L})$. The loss in calcium and gain in magnesium, as differences in concentrations between water-table ground water and effluent, decreased with time and apparently were approaching zero (fig. 8). These data suggest that, as the calcium-rich, magnesium-poor effluent percolated through the unsaturated-zone sediments, calcium ions displaced sorbed magnesium ions. Sorbed magnesium was originally present in about equal concentrations as calcium, as discussed previously. The exchange process was most active as effluent was initially transported through the unsaturated zone, when contrast between dissolved and sorbed concentrations was greatest. The exchange diminished as the dissolved and sorbed phases approached a new equilibrium. The loss of calcium ion generally was greater than the gain in magnesium ion (fig. 8) and must have been balanced by loss of negatively charged ions and(or) gain of hydrogen ion. Similar transient ion-exchange reactions commonly occur during artificial recharge when recharge waters are chemically distinct from ambient pore water or ground water (Wood and Signor, 1975; Valocchi and others, 1981; Idelovitch and Michail, 1984).

Changes in other constituents were small relative to changes in calcium and magnesium (fig. 8). Sodium concentrations decreased significantly $(p=0.0192)$, but not more than expected from dilution. The large decrease in potassium concentrations ( 45 percent) indicates that a significant fraction of potassium was sorbed or exchanged onto unsaturated-zone sediments (table 5). However, potassium concentrations in water-table ground water increased during the study period from less than $10 \mathrm{mg} / \mathrm{L}$ in January 1991 to about $25 \mathrm{mg} / \mathrm{L}$ in December 1992, suggesting that the sorption or exchange process was diminishing with time.

Finally, concentrations of silica and boron, minor constituents of effluent, also were altered in the unsaturated zone (table 5). Silica concentrations increased from a median of $1 \mathrm{mg} / \mathrm{L}$ in effluent to $17 \mathrm{mg} / \mathrm{L}$ in water-table ground water through reaction of effluent with silicate 


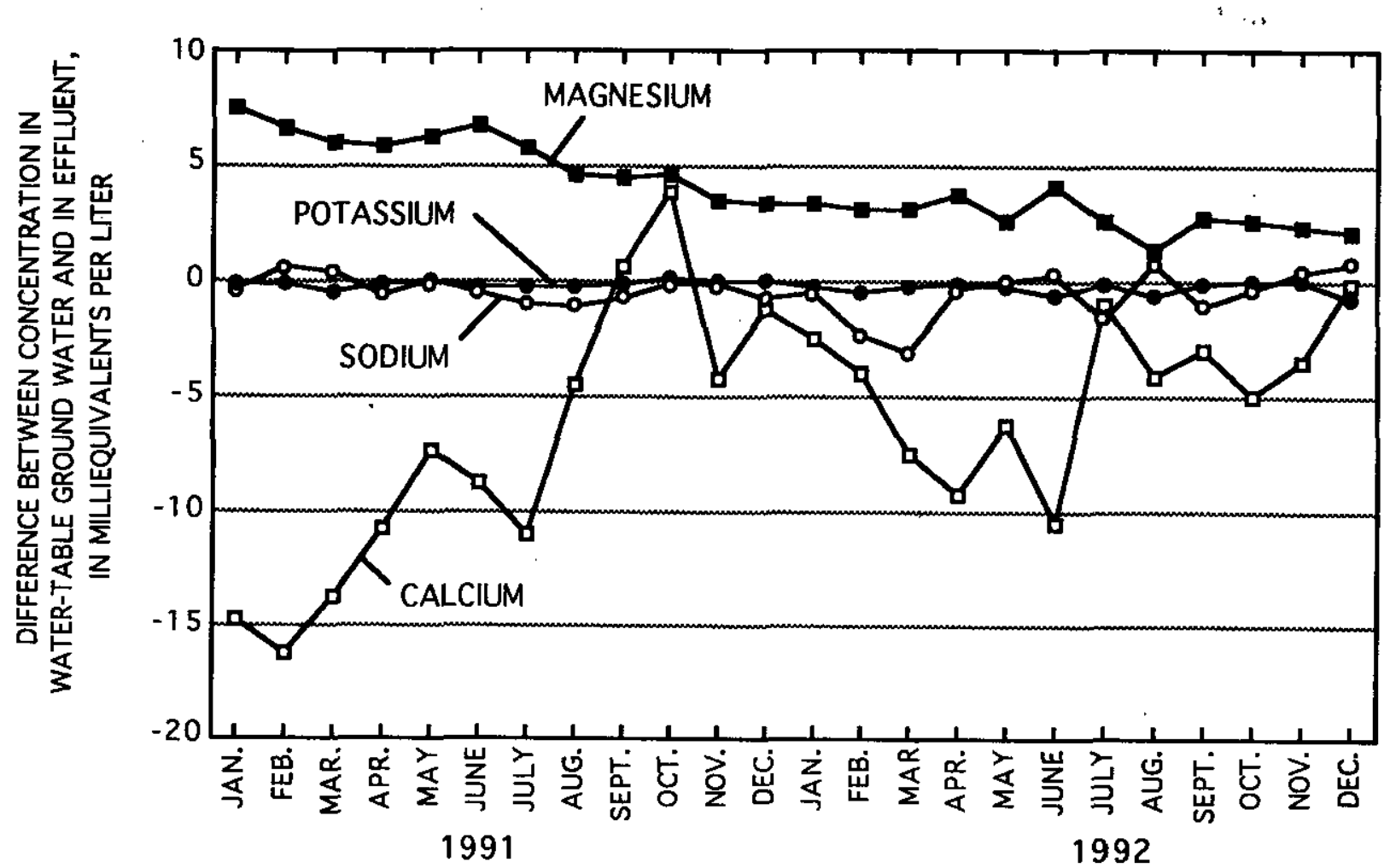

Figure 8. Monthly differences between ion concentrations in water-table ground water and in effluent, January 1991 through December 1992. Difference is equal to concentration in water-table ground water minus concentration in effluent, where concentrations are equally spaced monthly values. Monthly values obtained from linear interpolation between sample data and paired with a 3-month offset (the unsaturated-zone traveltime). Positive and negative differences correspond to increases and decreases, respectively, during transport through the unsaturated zone.

minerals. Increase in silica concentrations during artificial recharge of wastewater also was reported by Wood and Signor (1975). Boron concentrations decreased, and, as with potassium, the attenuation appeared to decrease with time. Adsorption of boron as borate is a possible mechanism for removal of boron from solution (Sposito, 1989).

In summary, changes in effluent properties and constituent concentrations during transport to the water table indicate the importance of reactive processes in the unsaturated zone. A decrease in the concentrations of total dissolved nitrogen was not identified, but the distribution of nitrogen species was altered. Reactions involving calcium, magnesium, sodium, potassium, and boron were approaching steady-state conditions after 34 months of effluent discharge. Major changes in the quality of effluent in the unsaturated zone included (1) transformations of dissolved organic nitrogen to ammonium and ammonium to nitrate; (2) attenuation of organic carbon, phosphorus, calcium, potassium, sulfate, alkalinity, and boron concentrations; and (3) increases in concentrations of hydrogen ion (measured as decrease in $\mathrm{pH}$ ), magnesium, and silica. These changes are assumed to result from the microbial processes of nitrogen mineralization, nitrification, and aerobic respiration and the chemical processes of sorption and (or) ion exchange. 


\section{PHYSICAL DEVELOPMENT AND CHEMICAL CHARACTERISTICS OF THE SEPTAGE- EFFLUENT PLUME}

The horizontal and vertical extent of the septageeffluent plume in ground water and rates and controls on its movement in the aquifer are described in this section. This distribution of specific conductance, chloride, dissolved oxygen, nitrogen species, phosphorus, dissolved organic carbon, and other constituents and properties in the aquifer also are presented. Constituent concentrations in December 1992 are depicted in maps, which show the maximum concentration measured in ground water from one to six wells at each cluster site. For dissolved oxygen, which was depleted in the maximumcontamination zones, minimum concentrations are depicted.

\section{Specific Conductance, Chloride, and Physical Development of the Plume}

Specific conductance and chloride are indicators of the physical development of the plume. Specific conductance, which is proportional to the dissolved-solids concentration (Hem, 1985, p. 167), can be used for a qualitative description of plume movement. Specific conductance of ground water in December 1992 ranged from more than $3,000 \mu \mathrm{S} / \mathrm{cm}$ in the center of the plume to less than $500 \mu \mathrm{S} / \mathrm{cm}$ near the boundaries of the plume (fig. 9 and table 6). The maximum areal extent of the plume slightly exceeds the line of equal specific conductance equal to $500 \mu \mathrm{S} / \mathrm{cm}$ in figures 9 and 10 , because $500 \mu \mathrm{S} / \mathrm{cm}$ is significantly greater than typical background values ( 75 to $304 \mu \mathrm{S} / \mathrm{cm}$, table 3). Chloride can be used for qualitative and quantitative description because it travels conservatively in ground water. The areal distribution of chloride, which made up about onehalf of the dissolved solids, was similar to that of specific conductance (fig. 10). Chloride concentrations in the center of the plume were greater than $800 \mathrm{mg} / \mathrm{L}$ and equaled the median concentration in effluent at site 147 (table 6 and fig. 11).

The areal distributions of specific conductance and chloride in the aquifer (figs. 9 and 11) show that the leading edge of the plume had traveled 200 to $450 \mathrm{ft}$ downgradient from the beds by December 1992. The plume also had split into two lobes by March 1991 (fig. 10 ). One lobe moved westward and the second lobe moved northwestward from the beds. By December 1992, the bilobate shape was less pronounced. The plume's initial bilobate shape resulted from the irregular geometry of the lower fine-grained unit near the infiltration beds. The top of this unit is close to the water table under the northwestern end of the infiltration beds, as described previously. Ground water preferentially flowed through thick coarse-grained sediments to the south and north of the northwestern corner of the beds.

The plume also extended at least 100 to $130 \mathrm{ft}$ east and south of the infiltration beds by December 1992 . This radial expansion, much of which occurred between September 1991 and June 1992, probably resulted from two factors. First, the water table beneath the infiltration beds was relatively flat even under pre-effluent discharge conditions. Second, the predominant area of effluent recharge to the aquifer changed during the study. During the winter and spring months of 1992, the four easternmost beds were used more frequently for effluent discharge, whereas previous to that time, the four westernmost beds were most frequently used.

Vertically, the septage-effluent plume is in the upper fine-grained and intermediate coarse-grained units near the infiltration beds and preferentially flows through the coarse-grained unit (figs. 12A-B). Farther downgradient, the plume generally was constricted to the intermediate coarse-grained unit by the underlying fine-grained unit. Along section $A-A$, which transects the westward lobe, the plume expanded vertically east and west of the downgradient end of the infiltration beds, because the coarse-grained unit thickens and mounding induced flow in these directions (fig. 12A). The downward displacement in the westward direction also is consistent with the strong downward gradients measured in that direction (fig. 3A). In contrast, the flow path was more horizontal in the northwestward direction (fig. 12B). In the northwestward direction, the septage-effluent plume had a more regular shape, was thinner, and was located at shallower depths (figs. 12B$C)$ than in the westward lobe (fig. 12A). These characteristics reflect the water-level altitudes and distribution of the coarse-grained and lower fine-grained units in the northwestward direction. 


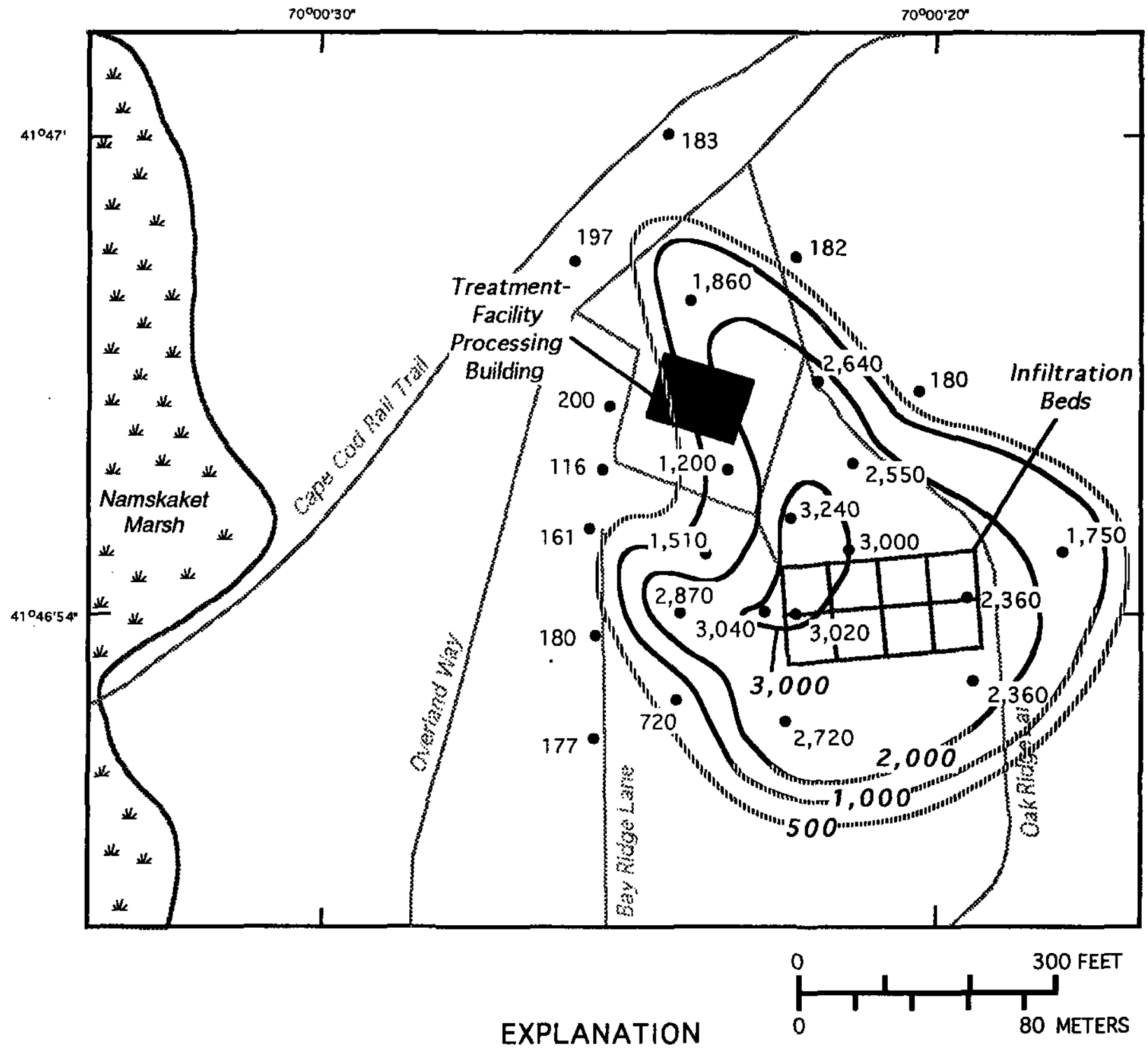

- 500 ......... LINE OF EQUAL SPECIFIC CONDUCTANCE--Dashed where approximately located. Interval, in microsiemens per centimeter at 25 degrees Celsius, is variable

$720^{\circ} \quad$ WELL CLUSTER SITE--Site of one or more observation wells completed at different depths. Number is maximum specific conductance, in microsiemens per centimeter at 25 degrees Celsius

Figure 9. Areal distribution of specific conductance in the septage-effluent plume, December 1992. 
Table 6. Physical propertles and concentrations of major chemical constituents, nutrients, and boron in ground water in the septage-effluent plume, December 1992

[Summary statistics for center of plume based on 11 samples in which chloride concentrations are greater than 800 milligrams per liter; summary statistics for leading edge of plume based on 11 samples in which chloride concentrations range from 200 to 500 milligrams per liter. Interquartile range is equal to the difference between 25 th and 75 th percentiles. Median concentrations for constituents less than the analytical detection limits were estimated using the robust probability method for censored data of Helsel and Cohn (1988) and Helsel (1990). $\mu \mathrm{S} / \mathrm{cm}$, microsiemen per centimeter at $25^{\circ} \mathrm{C}$; ${ }^{\circ} \mathrm{C}$, degree Celsius; $\mathrm{mg} / \mathrm{L}$, milligram per liter; $\mu \mathrm{g} / \mathrm{L}$, microgram per liter. --, no data]

\begin{tabular}{|c|c|c|c|c|}
\hline \multirow[b]{2}{*}{ Properties and constituents } & \multicolumn{2}{|c|}{ Center of plume } & \multicolumn{2}{|c|}{ Leading edge of plume } \\
\hline & Median & $\begin{array}{l}\text { Interquartile } \\
\text { range }\end{array}$ & Median & $\begin{array}{l}\text { Interquartile } \\
\text { range }\end{array}$ \\
\hline \multicolumn{5}{|l|}{ Physical properties } \\
\hline Specific conductance $(\mu \mathrm{S} / \mathrm{cm})$ & 3,020 & 230 & 1,500 & 540 \\
\hline pH (standard units) & 5.4 & .1 & 5.6 & .2 \\
\hline Temperature, water $\left({ }^{\circ} \mathrm{C}\right)$ & 12.1 & 1.4 & 10.5 & 1.3 \\
\hline Oxygen, dissolved $(\mathrm{mg} / \mathrm{L})$ & .05 & $<.05$ & 3.9 & 1.5 \\
\hline Dissolved solids, sum of constituents $(\mathrm{mg} / \mathrm{L})$....................... & 1,440 & 97 & 679 & 183 \\
\hline \multicolumn{5}{|l|}{ Major constituents (mg/L) } \\
\hline Calcium & 350 & 48 & 88 & 22 \\
\hline Magnesium & 28 & 8 & 59 & 26 \\
\hline Sodium & 110 & 8 & 51 & 10 \\
\hline 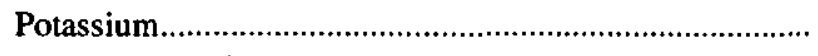 & 22 & 8 & 4.2 & 1.3 \\
\hline Alkalinity, total (as $\left.\mathrm{CaCO}_{3}\right)$ & 1 & 4.6 & 9 & 3.9 \\
\hline Sulfate $^{1}$ & 2 & 5.3 & 1.3 & 2.6 \\
\hline Chloride & 860 & 53 & 390 & 130 \\
\hline Silica & 14 & 3 & 12 & 2 \\
\hline \multicolumn{5}{|l|}{ Nutrients $(\mathbf{m g} / \mathbf{L})$} \\
\hline Nitrate, dissolved (as N) & 32 & 4.9 & 12 & 7.2 \\
\hline Nitrite, dissolved (as N) & .08 & .05 & .02 & .01 \\
\hline Nitrogen, ammonium, dissolved (as $\mathrm{N})^{1} \ldots \ldots \ldots \ldots \ldots \ldots \ldots$ & 6.4 & 2.6 & .02 & .03 \\
\hline Nitrogen, organic, ${ }^{2}$ dissolved (as $\left.\mathrm{N}\right)^{1}$ & .5 & .7 & .06 & .2 \\
\hline 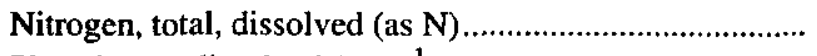 & 41 & 8.5 & 12 & 7.5 \\
\hline Phosphorus, dissolved (as P) ${ }^{1}$ & .02 & .01 & .03 & .03 \\
\hline 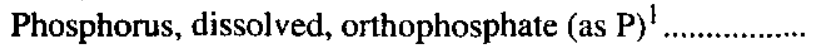 & .02 & .02 & .02 & .01 \\
\hline \multicolumn{5}{|l|}{ Trace constituents $(\mu \mathrm{g} / \mathrm{L})$} \\
\hline Boron & 200 & 70 & 30 & 30 \\
\hline \multicolumn{5}{|l|}{ Organic carbon (mg/L) } \\
\hline 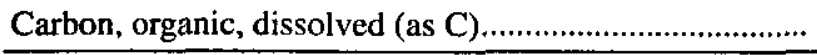 & 1.9 & 6 & .5 & .2 \\
\hline
\end{tabular}

${ }^{1}$ Analyses include detections less than analytical detection limits.

${ }^{2}$ Organic nitrogen calculated as the difference between separate analyses of ammonium plus organic nitrogen and ammonium nitrogen. 


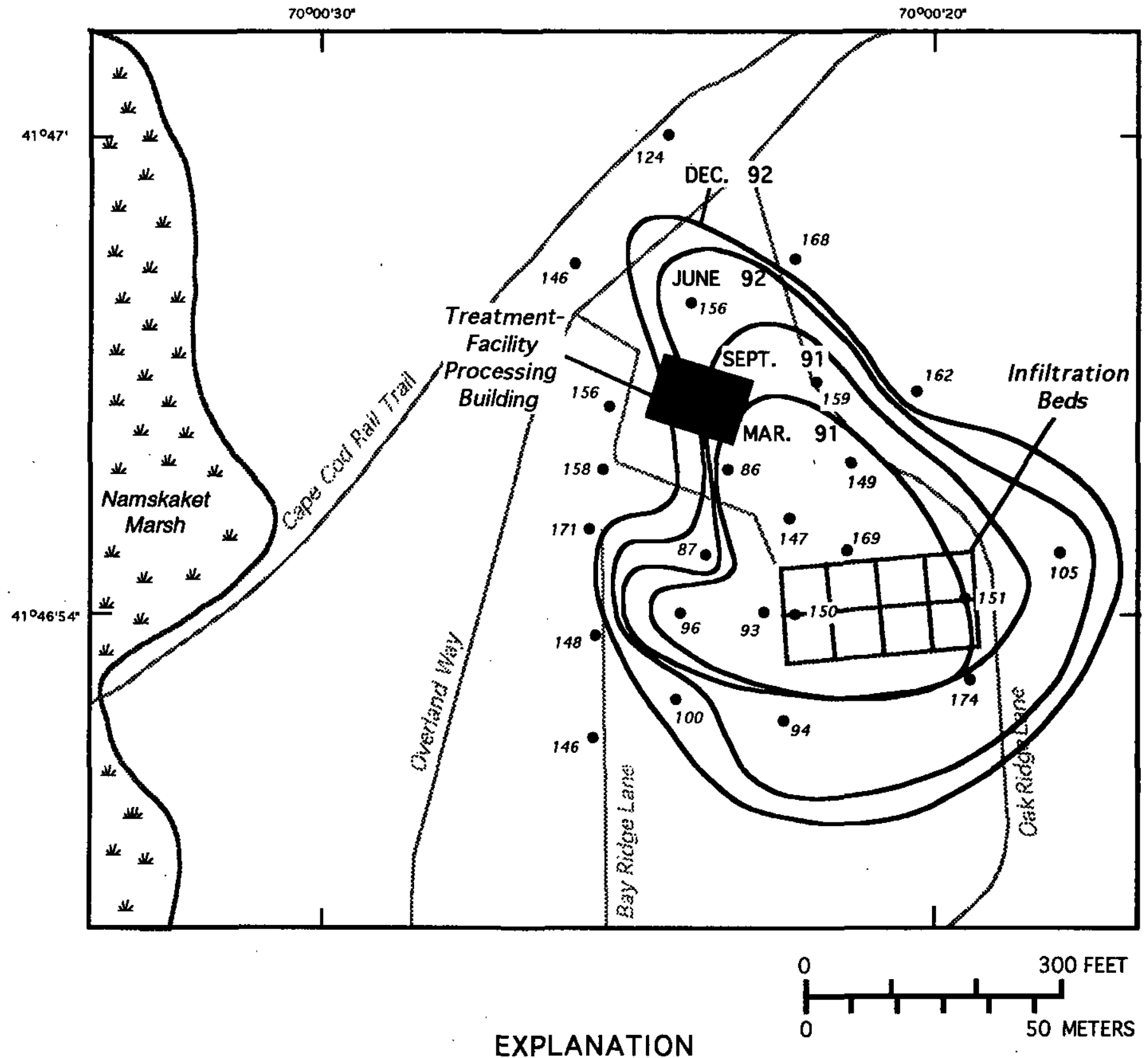

- LINE OF EQUAL SPECIFIC CONDUCTANCE APPROXIMATELY EQUAL TO 500 MICROSIEMENS PER CENTIMETER AT 25 DEGREES CELSIUS

$174^{\circ}$ WELL CLUSTER SITE--Site of one or more observation wells completed at different depths. Number is site identifier (see table 12)

Figure 10. Areal distribution of specific conductance in the septage-effluent plume, March and September 1991 and June and December 1992. 


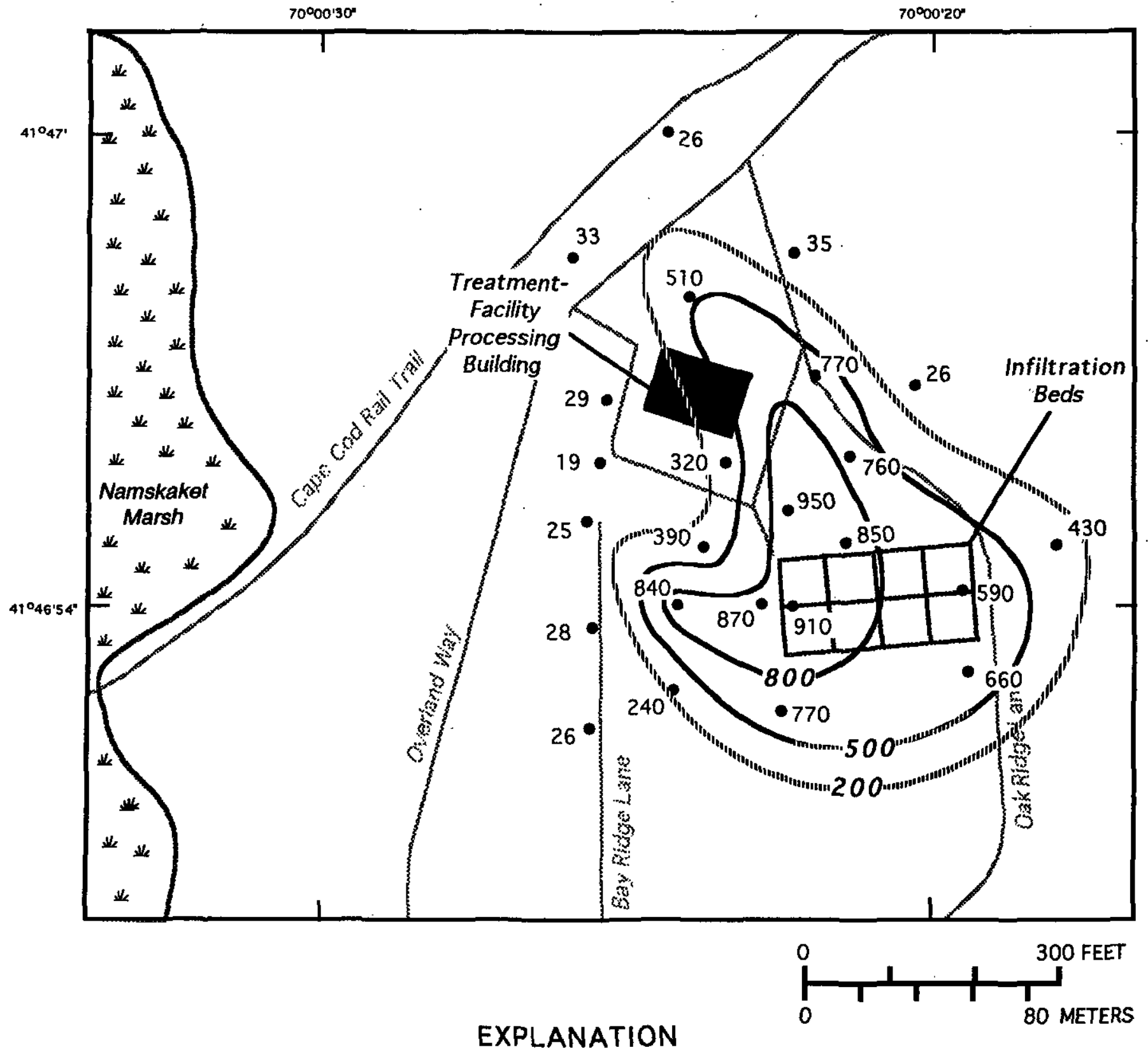

- 500 m.n..... LINE OF EQUAL CHLORIDE CONCENTRATION--Dashed where approximately located. Interval, 300 milligrams per liter

$240^{\circ}$ WELL CLUSTER SITE--Site of one or more observation wells completed at different depths. Number is maximum chloride concentration, in milligrams per liter

Figure 11. Areal distribution of chloride concentrations in the septage-effluent plume, December 1992. 
A

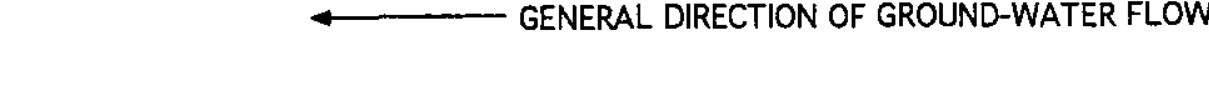

EAST

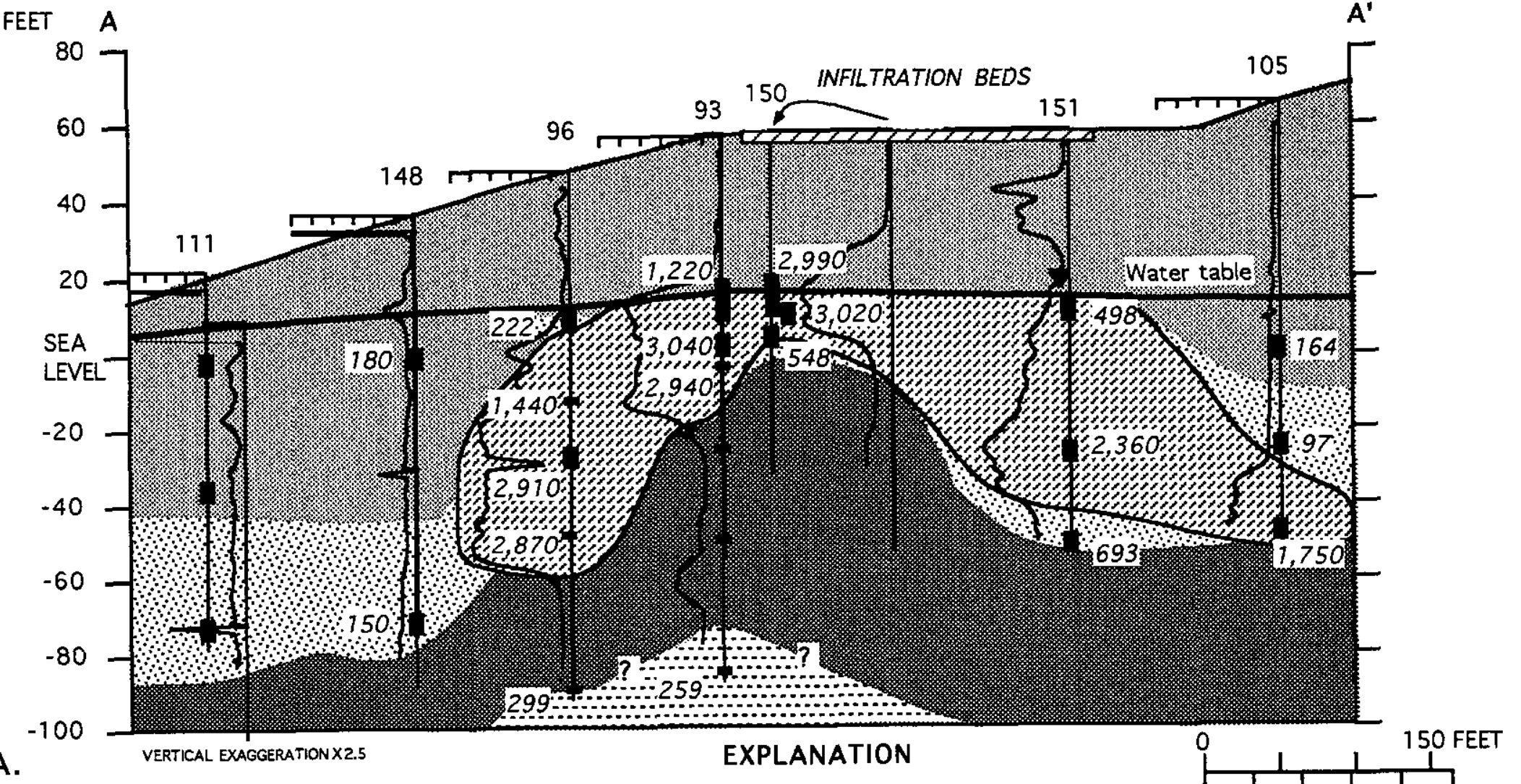

A.
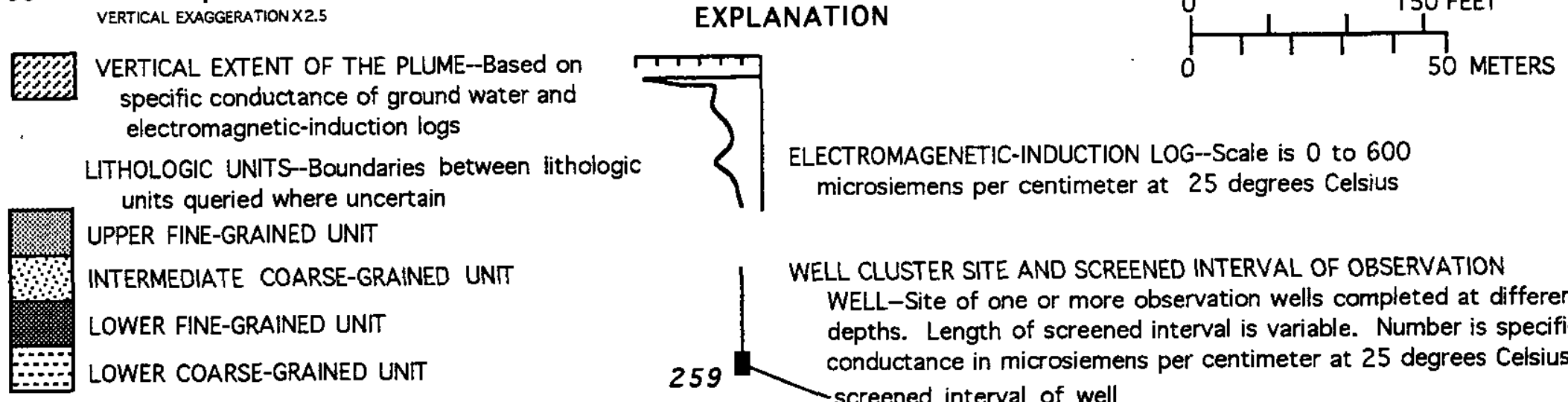

ELECTROMAGENETIC-INDUCTION LOG--Scale is 0 to 600 microsiemens per centimeter at 25 degrees Celsius units queried where uncertain

WELL CLUSTER SITE AND SCREENED INTERVAL OF OBSERVATION

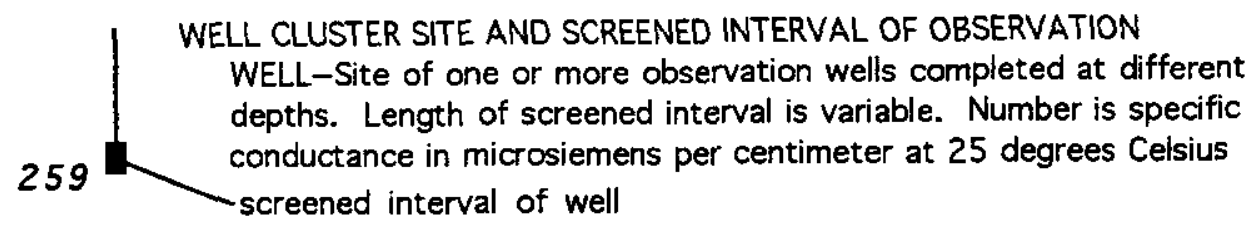

Figure 12. Vertical distribution of specific conductance and electromagnetic-induction logs along (A) section $A-A^{\prime},(B)$ section $B-B^{\prime}$, and (C) section $C-C^{\prime}$ in the septage-effluent plume, December 1992. (Line of hydrogeologic sections shown in figure 2 .) 


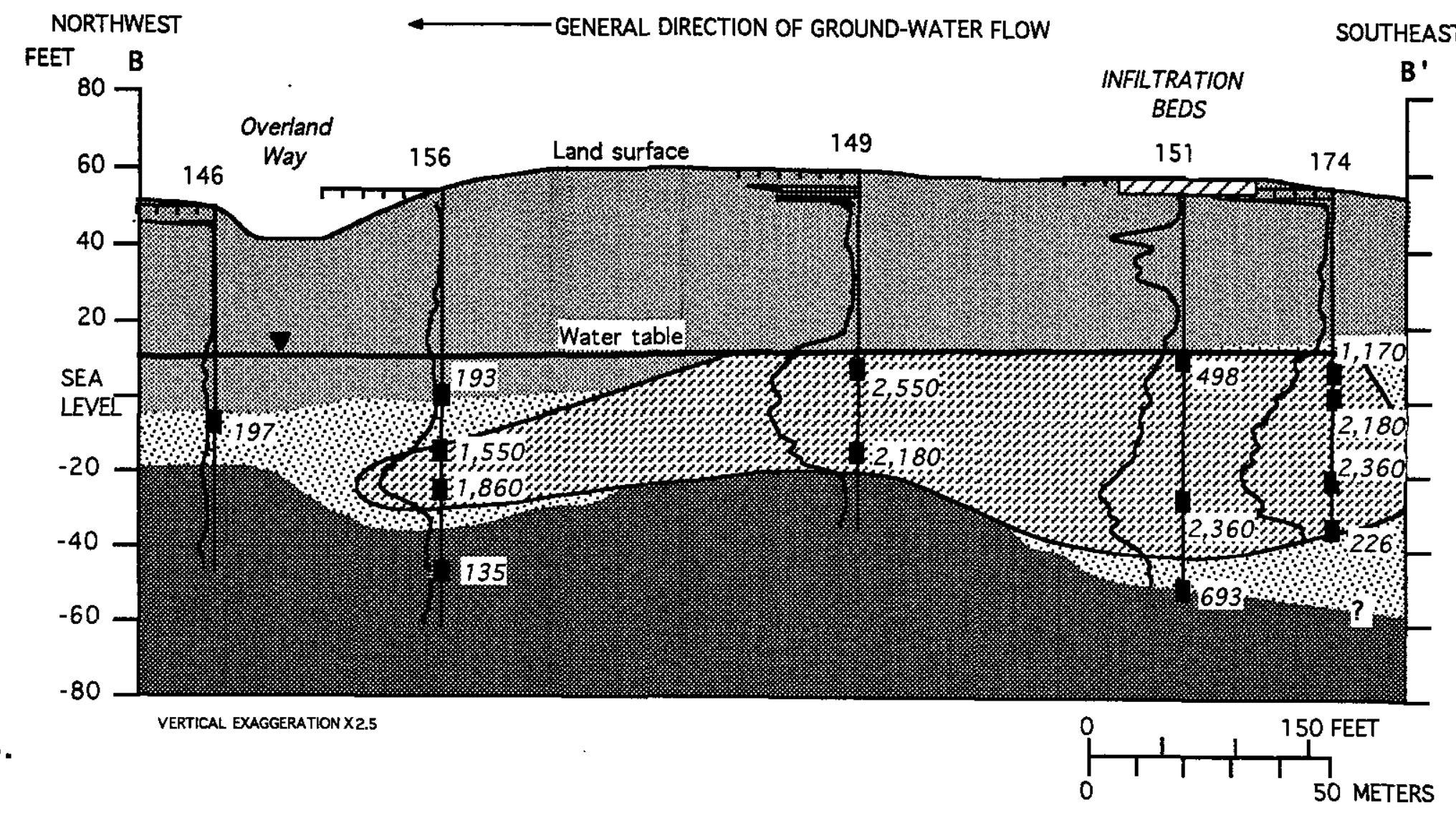

Figure 12. Vertical distribution of specific conductance and electromagnetic-induction logs along $(A)$ section $A-A^{\prime}$, (B) section $B-B^{\prime}$, and $(C)$ section $C-C^{\prime}$ in the septage-effluent plume. December 1992-Continued. 


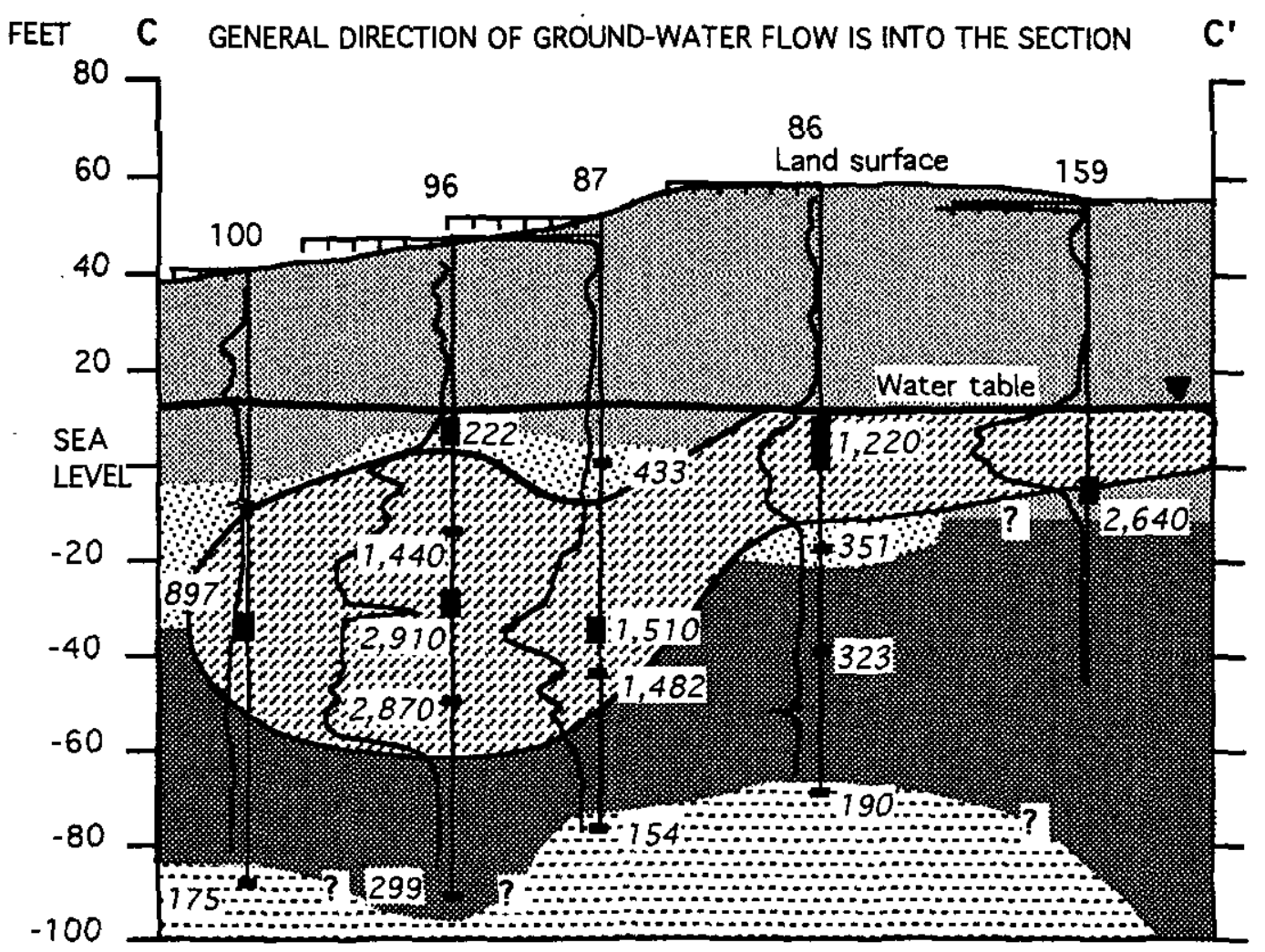

VERTICAL EXAGGERATION X2.5

C.

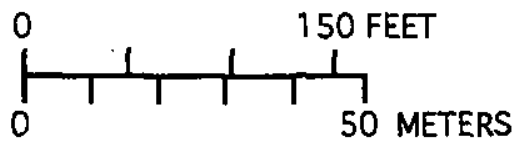

Figure 12. Vertical distribution of specific conductance and electromagnetic-induction logs along $(A)$ section $A-A^{\prime},(B)$ section $B-B^{\prime}$, and $(C)$ section $C-C^{\prime}$ in the septage-effluent plume, December 1992-Continued. 
Density effects also may have caused downward movement of the plume. These effects would have been largest near the infiltration beds where density differences between effluent-contaminated and ambient ground water were greatest. Density differences are diminished with distance from the beds by mixing with ambient ground water through dispersion. The density difference between effluent-contaminated and ambient ground water was on the order of $0.001 \mathrm{~g} / \mathrm{cm}^{3}$, as determined from dissolved-solids concentrations and water temperatures in effluent and ground water. This difference was likely sufficient to add to the downward movement resulting from vertical head gradients and lithologic heterogeneity (Schincariol and Schwartz, 1990; LeBlanc and Celia, 1991).

Sequential EM logs at individual cluster sites illustrate the small-scale vertical variation in concentrations in the plume that resulted from velocity differences along vertically adjacent flow paths (fig. 13). The EM logs show a general pattern of expansion of initially thin, discrete conductivity peaks. At site 93 in the westward lobe, the plume expanded from an initial 8-foot-thick single peak (June 1990) to a 28-foot-thick bilobed zone extending from the water table to the bottom of the coarse-grained unit (March 1991; fig. $13 A$ ). At site $96,100 \mathrm{ft}$ downgradient, the initial 10-foot-thick peak (December 1990) occurred at an.altitude of -45 to $-55 \mathrm{ft}$ (fig. 13B). The 40 -foot vertical displacement of the leading edge of the plume between these two sites resulted from the vertical head gradients, lithologic variability, and also possible density differences, as discussed previously. The single peak at site 96 expanded upward into a 40 -foot thick zone of uniformly high conductivity (July 1992); subsequently, a second peak zone developed near the water table (December 1992; fig. 13B). The initial thin, discrete conductivity peaks shown by the EM logs represent intersection of the cluster site with the most rapidly moving "fingers" of the leading edge and(or) with the shortest flow paths from the infiltration beds. Vertical differences in plume velocity likely were due to hydraulic-conductivity variations associated with the high variability in particle-size characteristics of aquifer sediments, such as found by Hess and others (1992) in outwash deposits elsewhere on Cape Cod.
Small-scale spatial differences in velocity that result from aquifer heterogeneity contribute to dispersion, which is the spreading out of the contaminant front with time and space. Dispersion results from the molecular diffusion and the mechanical mixing of effluentcontaminated ground water with ambient ground water during flow. Dispersion generally is greatest in the direction of flow (longitudinal dispersio and can increase with travel distance from the source (LeBlanc and others, 1991). Dispersion also occurs in directions perpendicular to flow (transverse dispersion). Moreover, transverse and longitudinal dispersion in threedimensional flow occur over multiple flow paths of varying direction and velocity. The effects of dispersion are evident in the decreasing chloride concentrations with distance from the infiltration beds (fig. 11). The slow increase in chloride concentrations with time at individual sampling points (fig. 14), or breakthrough curve, also results from dispersion. Chloride concentration in ground water is expressed relative to the median effluent concentration in the breakthrough curves shown in figure 14.

Chloride concentrations increased most rapidly where the screened interval of the sampled well most closely coincided with the peak conductivity zone at a site and where the site was near the center line of plume transport. For example, concentrations at OSW 90 (fig. 14A) increased less rapidly than at OSW 98 (fig. 14B). This is contrary to expectation because OSW 90 , at site 93, is much closer to the infiltration beds than OSW 98, at site 96 (fig. 10). However, OSW 98 was screened in the initial peak conductivity zone, whereas OSW 90 was not. Thus, OSW 90 (screened at 3.1 to $4.1 \mathrm{ft}$ below sea level) intercepted a more slowly moving vertical zone of the plume that had experienced greater dispersion than the peak zone at that site (at 2 to $10 \mathrm{ft}$ above sea level), which was not sampled. Similarly, concentrations at OSW 98 increased more rapidly than at OSW 114 (fig. 14C), which was screened above the peak conductivity zone at site 96 . Finally, concentrations at OSW 107 (fig. 14D) illustrate the effect of horizontal distance from the center line of plume transport. OSW 107 (site 149 , fig. 10) was screened in the peak conductivity zone and is about the same distance from the infiltration beds as OSW 98. However, concentrations at OSW 107 


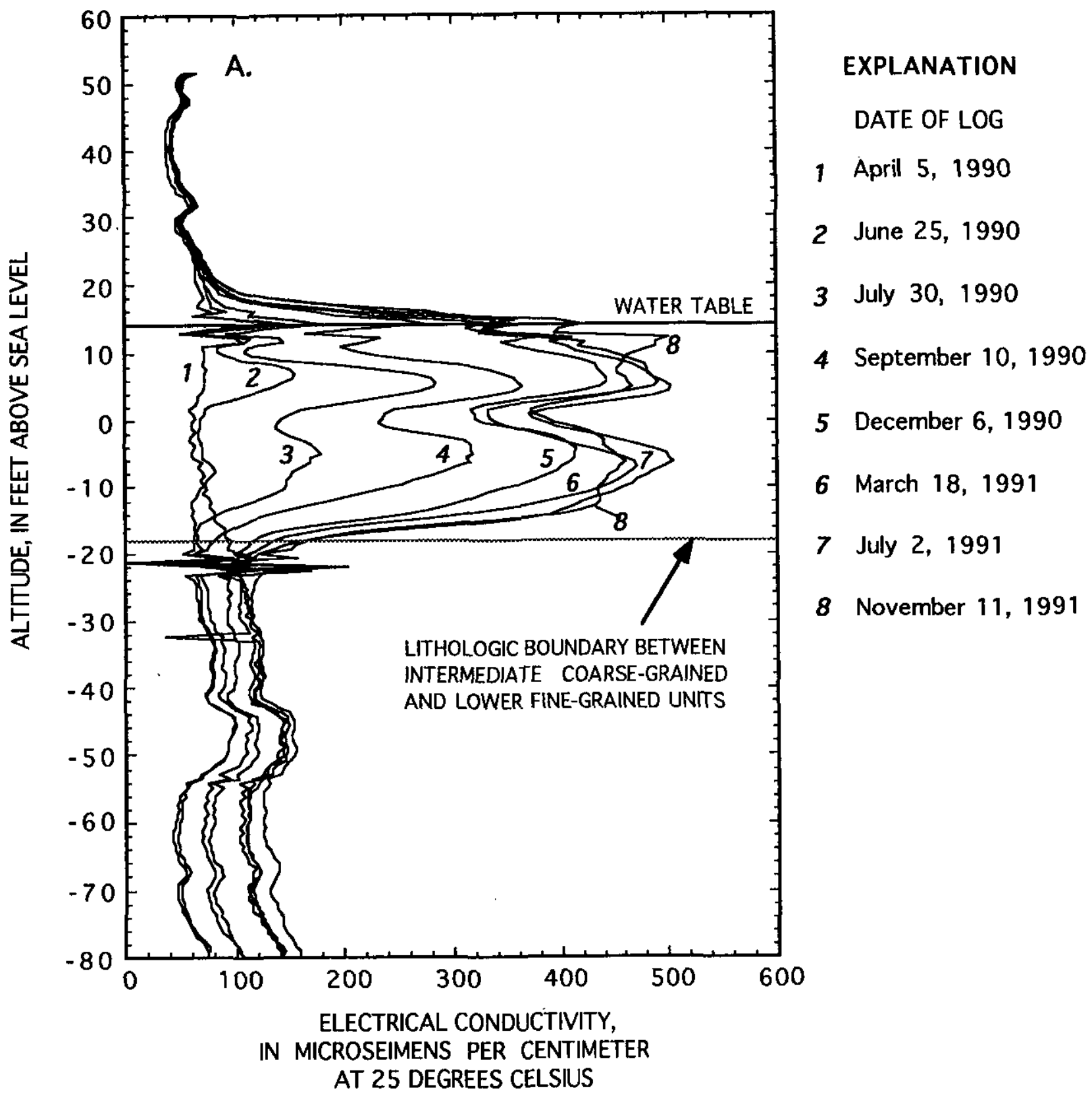

Figure 13. Vertical heterogeneity in the septage-effluent plume illustrated by sequential electromagnetic-induction logs at two sites in the westward lobe. A. Site 93. B. Site 96. (Location of sites shown in figures 2 and 10 .)

required about twice the time required at OSW 98 to reach one-half of the input concentration. This results from the slower velocities and greater dispersion that occur near the plume's lateral edges than along the center line of transport. The slow increases in concentrations near the lateral edges also may result from laterally diverging flow paths in the plume as it moves away from the infiltration beds.
The mean linear velocity of ground water in the plume can be determined by dividing the distance to a sampling point by the time required for chloride concentrations to reach one-half of the effluent-input concentration (the midpoint of the breakthrough curve; Freeze and Cherry, 1979, p. 391). Mean linear groundwater velocity was calculated from breakthrough curves for OSW 98 (site 96) in the westward lobe and OSW 


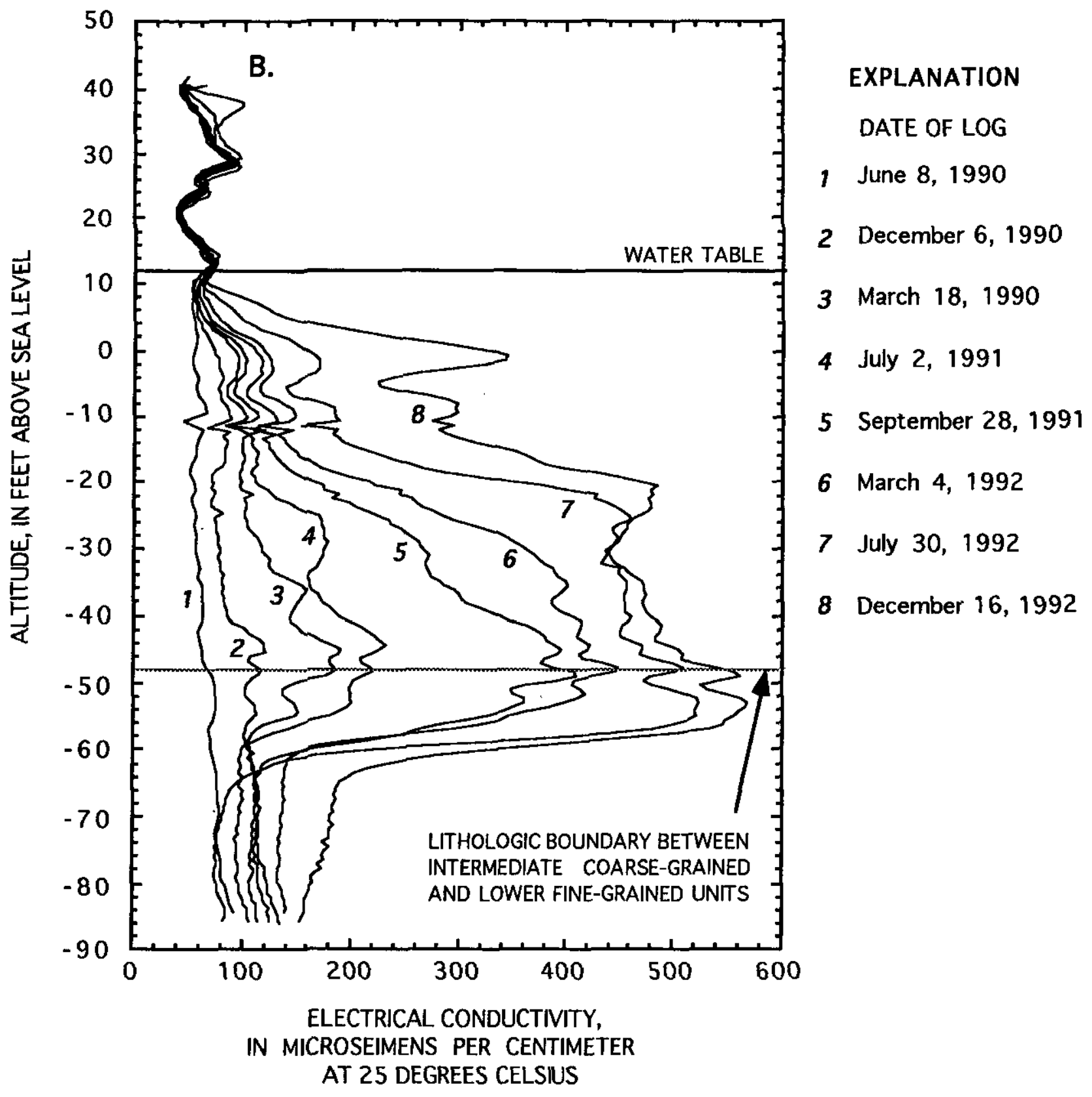

Figure 13. Vertical heterogeneity in the septage-effluent plume illustrated by sequential electromagnetic-induction logs at two sites in the westward lobe. A. Site 93. B. Site 96-Continued.

161 (site 156) in the northwestward lobe. At these sites, the sampled wells were closest to the vertical and horizontal center line of plume transport. The length of a three-dimensional flow path extending from the water table beneath the infiltration beds to the well was divided by the time-of-travel to obtain velocity. The time-of-travel was estimated as the time from the initiation of discharge to the midpoint of the breakthrough curve, adjusted for the unsaturated-zone traveltime. Flow-path distances of 188 and $431 \mathrm{ft}$ were estimated for OSW 98 and OSW 161 from map and sectional views of the ground-water-flow system. Mean linear velocities of $0.44 \mathrm{ft} / \mathrm{d}$ in the westward lobe and $0.47 \mathrm{ft} / \mathrm{d}$ in the northwestward lobe were thus determined. 

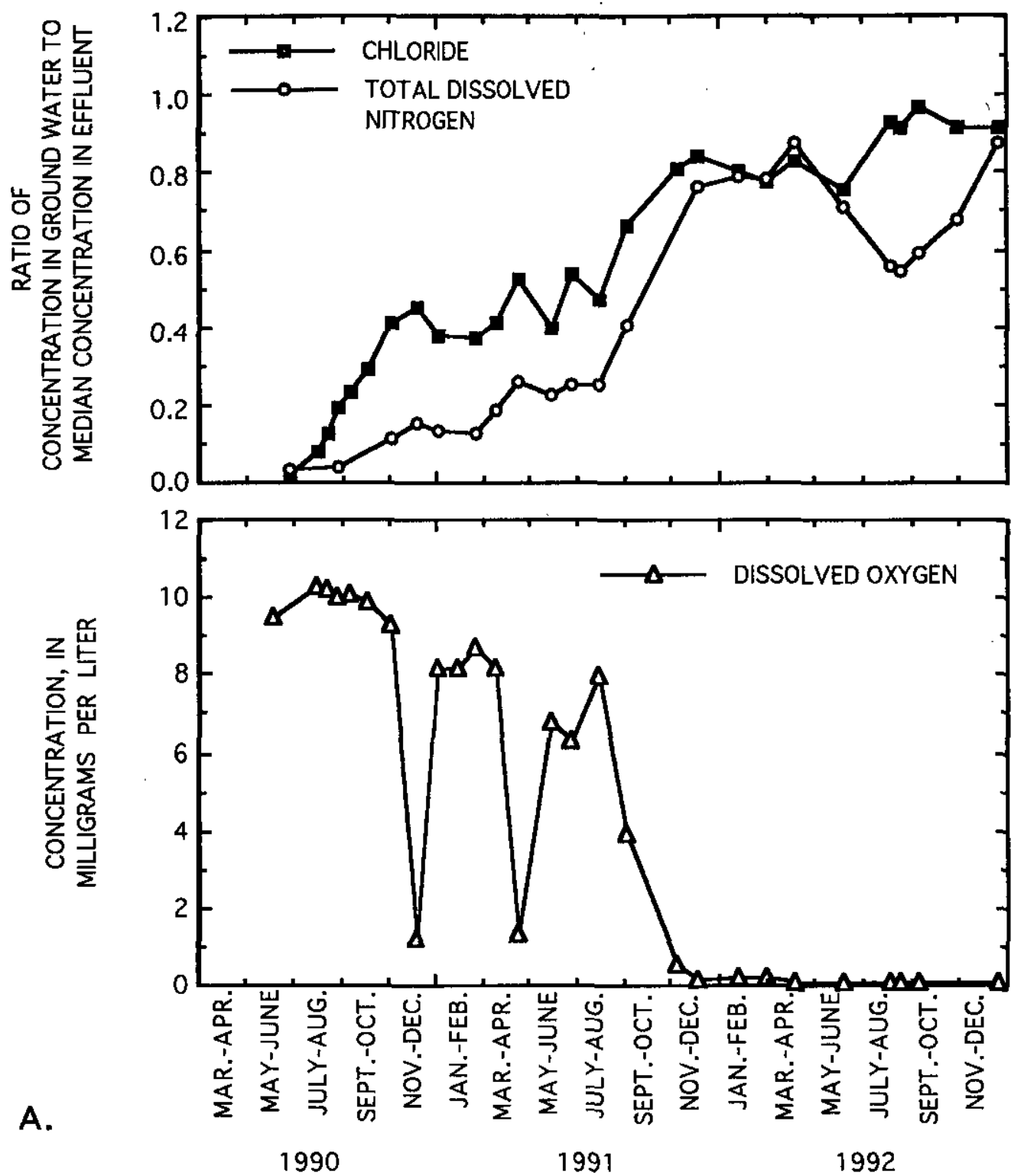

Figure 14. Concentrations of chloride, total dissolved nitrogen, and dissolved oxygen with time at five wells at four sites in the septage-effluent plume. (Location of sites shown in figures 2 and 10.) A. OSW 90, screened at 3.1 to 4.1 feet below sea level, site 93. B. OSW 98, screened at 47.8 to 48.8 feet below sea level, site 96. C. OSW 114, screened at 26.5 to 27.5 feet below sea level, site 96. D. OSW 107, screened at 10.5 to 5.5 feet above sea level, site 149. E. OSW 161, screened at 23.6 to 28.6 feet below sea level, site 156 .

Hydraulic conductivity was calculated from the plume movement to verify the estimated flow paths and velocities. Hydraulic conductivity was calculated from the Darcy relation,

$$
v=\frac{K}{n} \times \frac{d h}{d l}
$$

where $v$ is the mean linear velocity in feet per day, $K$ is the hydraulic conductivity in feet per day, $n$ is the porosity (as a ratio of void volume to total volume), and $d h / d l$ is the hydraulic gradient in foot per foot. Hydraulic gradients were $0.0050 \mathrm{ft} / \mathrm{ft}$ for the flow path to OSW 98 and a range of 0.0057 to $0.0062 \mathrm{ft} / \mathrm{ft}$ for the flow path to OSW 161. Porosity was assumed equal to 0.39 , as discussed previously. The resulting estimates of hydraulic 

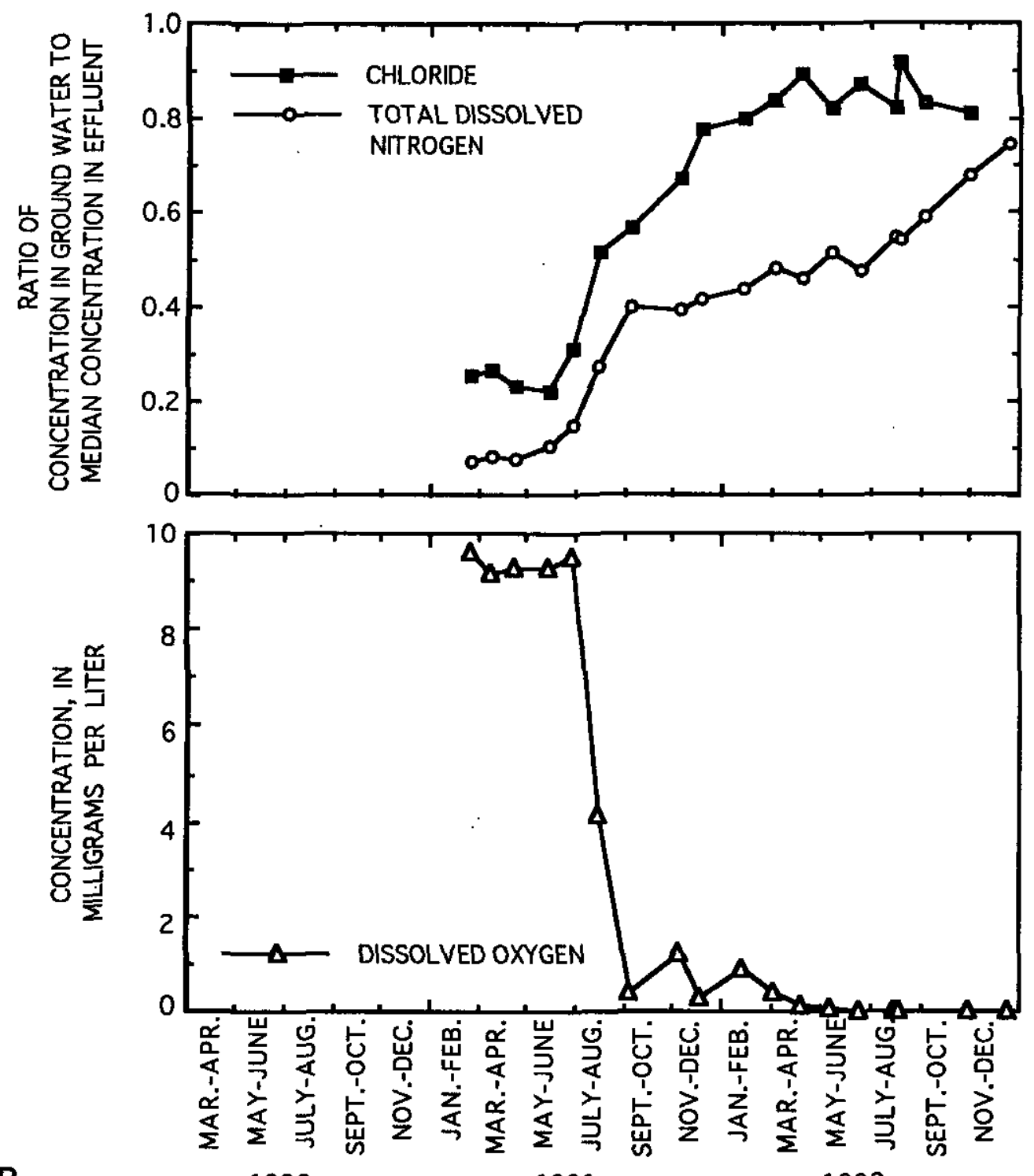

B.

1990

1991

1992

Figure 14. Concentrations of chloride, total dissolved nitrogen, and dissolved oxygen with time at five wells at four sites in the septage-effluent plumeContinued

conductivity are $34 \mathrm{ft} / \mathrm{d}$ for the flow path to OSW 98 and a range of 30 to $33 \mathrm{ft} / \mathrm{d}$ for the flow path to OSW 161. These values are within the range estimated from particle-size-distribution data for the intermediate-coarse grained unit (table 2). They fall between the estimates for medium to fine sand and coarse to medium sand. Because the hydraulic conductivity estimates from plume movement integrate the hydraulic conductivity of all sediments transited by the plume, they are lower than the hydraulic conductivity of the coarsest-grained sediments in the unit. They also may reflect the plume's three-dimensional flow paths and anisotropy in hydraulic conductivity of the aquifer sediments. The hydraulic conductivity of the coarse-grained sediments in the direction of flow is less than the horizontal hydraulic conductivity, when the direction of flow had a vertical component. The close agreement between the hydraulic conductivity determined from the actual plume movement and values independently estimated from other methods confirms the interpretation of lithologic and hydrologic controls on the physical development of the plume. 

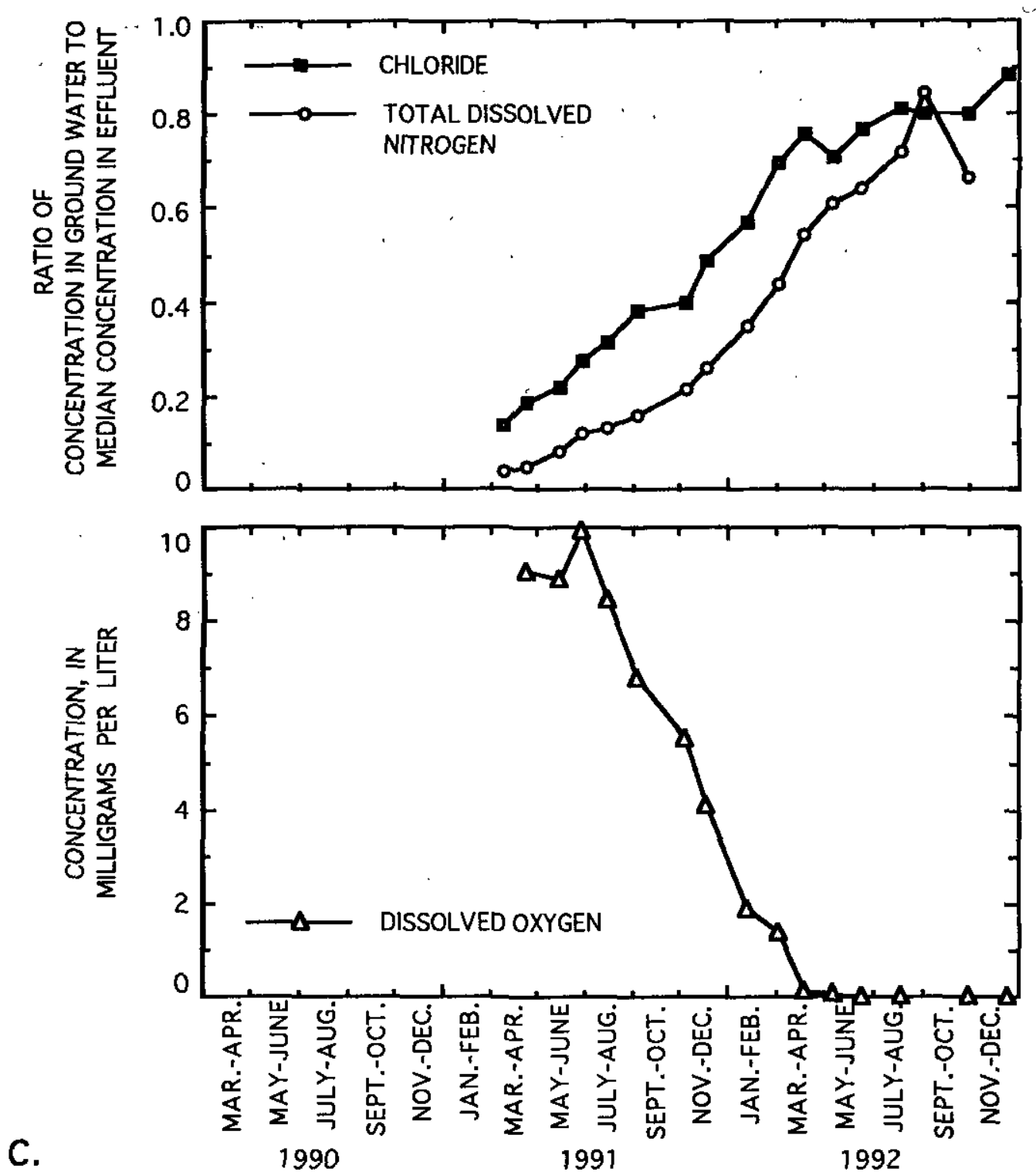

Figure 14. Concentrations of chloride, total dissolved nitrogen, and dissolved oxygen with time at five wells at four sites in the septage-effluent plume-Continued

\section{Chemical Characteristics}

\section{Dissolved Oxygen}

Dissolved-oxygen concentrations in the center of the plume were near zero in December 1992 (fig. 14A). The central anoxic zone was surrounded by a suboxic zone (fig. 15), where concentrations were greater than $0.05 \mathrm{mg} / \mathrm{L}$ but less than background concentrations. Dissolved-oxygen concentrations less than $0.05 \mathrm{mg} / \mathrm{L}$ were first measured in September 1991 at site 147 (fig. 16). The anoxic zone had expanded considerably by June 1992 (fig. 15).

Dissolved-oxygen concentrations at individual wells decreased with time from background concentrations of 8 to $10 \mathrm{mg} / \mathrm{L}$ as the septage-effluent plume expanded in the aquifer (indicated by increasing chloride concentrations). At OSW 90, OSW 98, and OSW 107, most of the decrease in dissolved-oxygen 


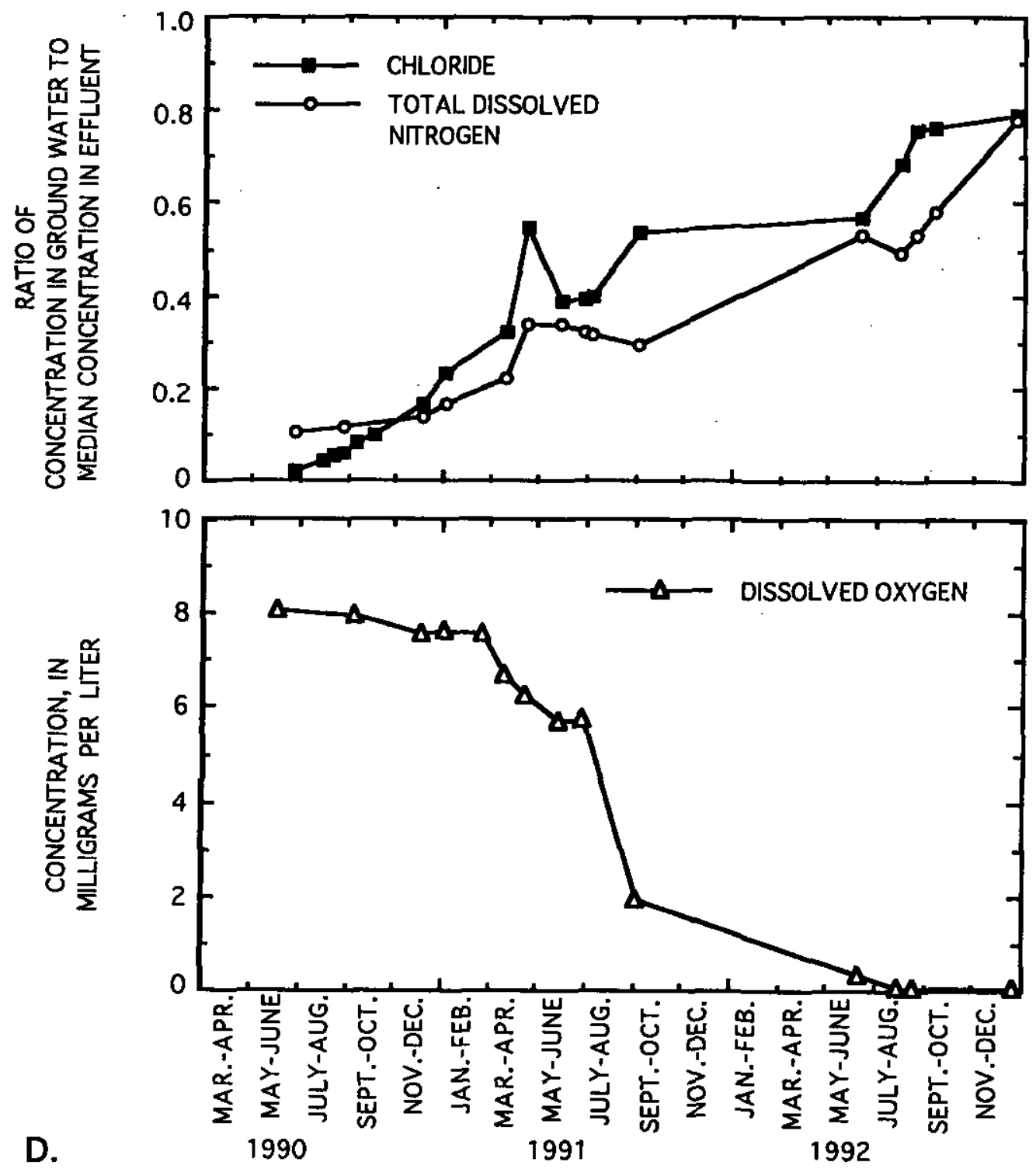

Figure 14. Concentrations of chloride, total dissolved nitrogen, and dissolved oxygen with time at five wells at four sites in the septage-effluent plumeContinued

concentrations took place over a 1 - to 2 -month period that approximately coincided with the midpoint of the chloride breakthrough curve (figs. $14 A, B$, and $D$ ). This suggests that the anoxic zone expanded at a rate comparable to the mean ground-water velocity and was characterized by sharp boundaries. At OSW 90, the gradual decrease in dissolved oxygen through September 1991 was punctuated by anomalously low measurements, each accompanied by a slight chloride peak. This further suggests that the anoxic zone was a sharply bounded thin layer at site 93 . At times, this anoxic layer approached the screened interval of the well or could be induced to do so through pumping.

The development of anoxic conditions in the plume is conceptually depicted in figure 17 (modeled after Borden and Bedient, 1986, fig. 1). Effluent, when discharged, contains dissolved-oxygen concentrations of about 7 to $9 \mathrm{mg} / \mathrm{L}$ (James Burgess, Orleans, Eastham, and Brewster Groundwater Protection District, Orleans, 

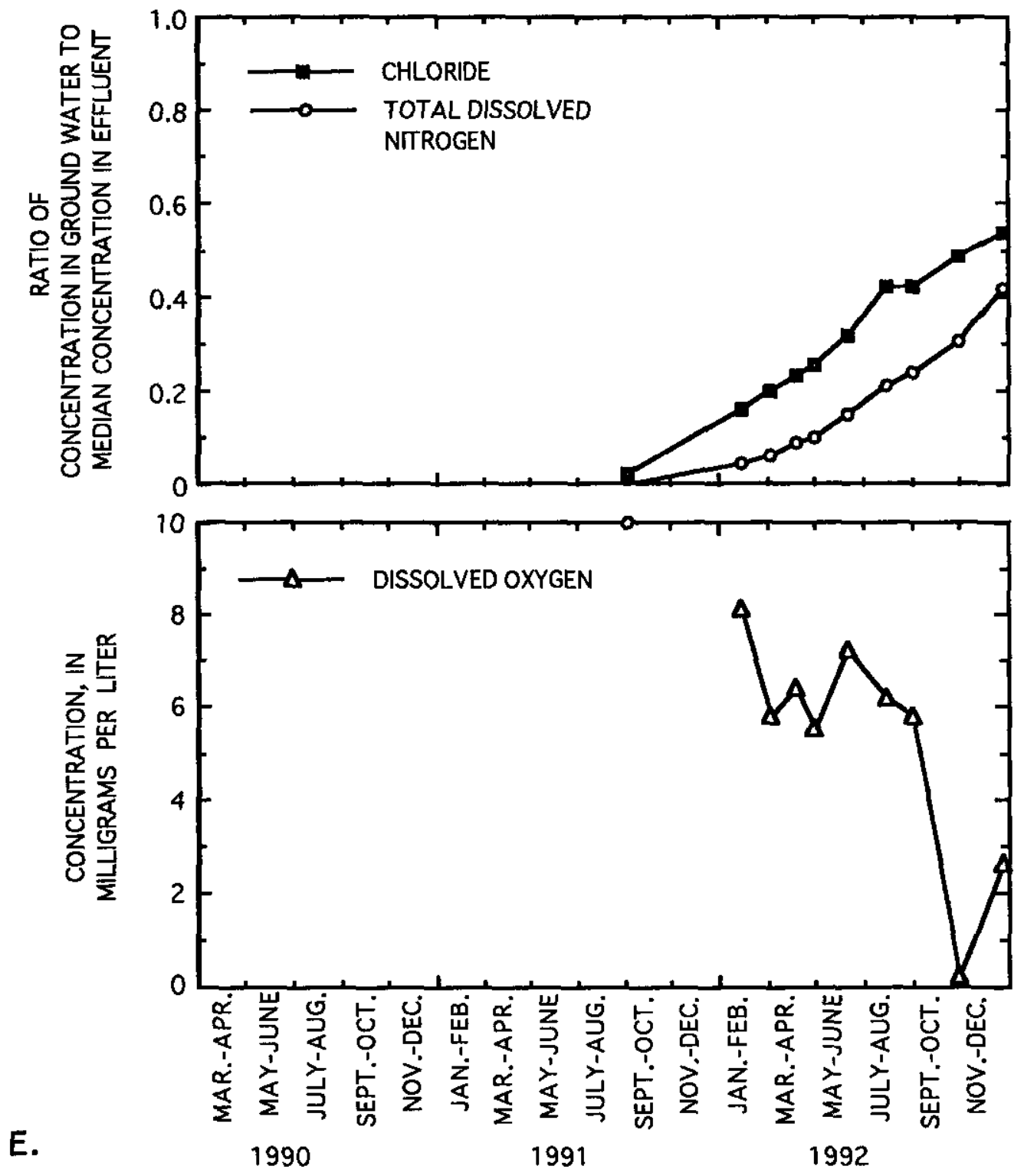

Figure 14. Concentrations of chloride, total dissolved nitrogen, and dissolved oxygen with time at five wells at four sites in the septage-effluent plumeContinued

Mass., written commun., 1990-92). Dissolved oxygen is consumed in the unsaturated zone through aerobic respiration and nitrification; it also may be replenished through unsaturated-zone gas transfer. The suboxic zone of oxygen depletion extends for a short distance into the saturated zone. In the anoxic zone, farther downgradient in the saturated zone, dissolved-oxygen concentrations are near zero. Beyond the anoxic zone is a suboxic zone of dispersive mixing, where dissolvedoxygen concentrations vary from anoxic-zone to background concentrations. The decrease in dissolved oxygen with time at a site thus corresponds to transport of the mixing zone past the site. The anoxic zone expands primarily through advective transport of the anoxic ground water. This is evidenced by the coinciding midpoints of the breakthrough curves for oxygen depletion and chloride (fig. 14). At the boundary between the anoxic and the suboxic mixing zones, the residual dissolved organic carbon and ammonium in the 


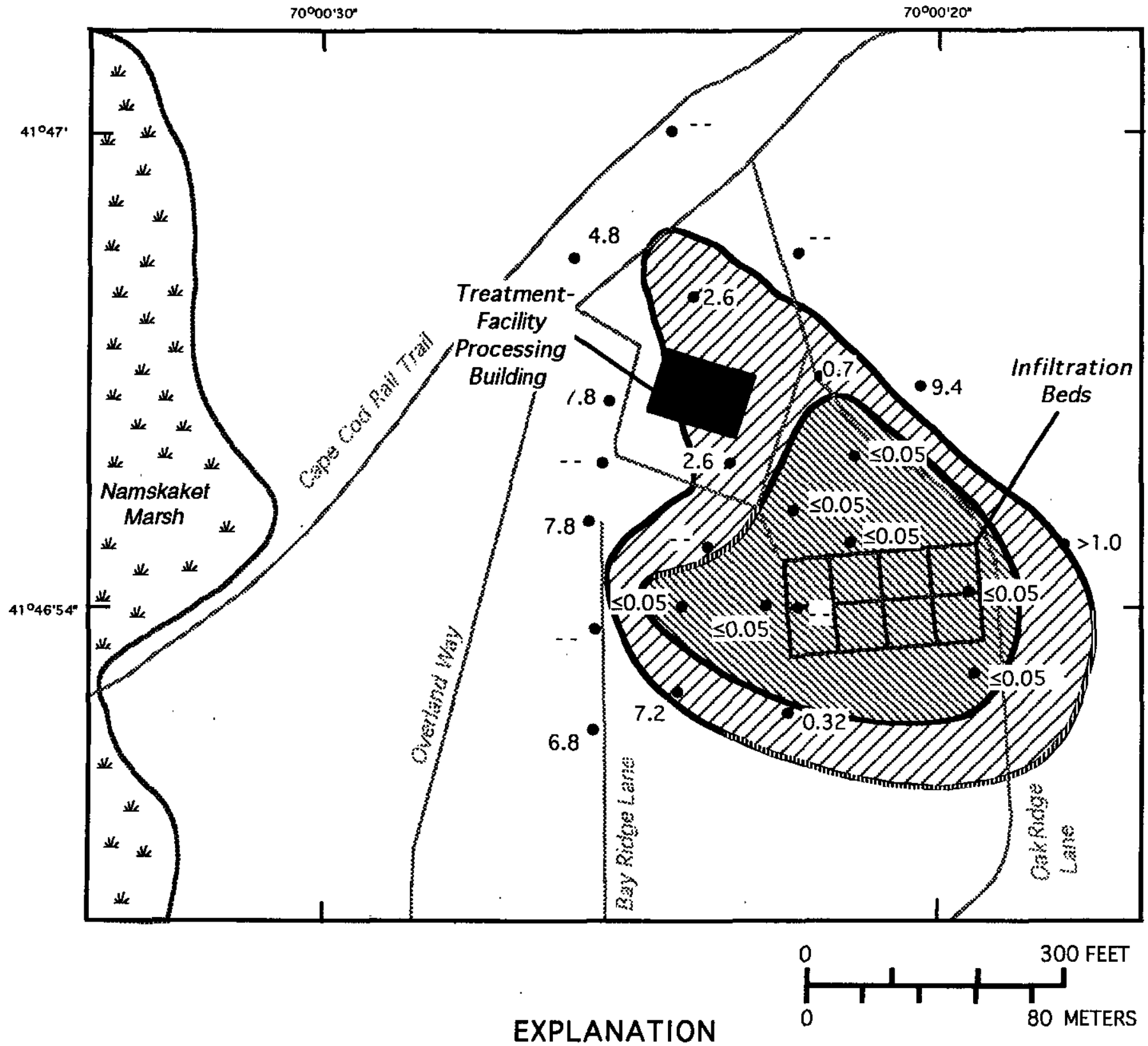

ANOXIC ZONE--Dissolved-oxygen concentrations less than or equal to 0.05 milligram per liter. Boundary dashed where approximately located

SUBOXIC ZONE--Dissolved-oxygen concentrations greater than 0.05 milligram per liter and less than background concentrations. Boundary dashed where approximately located

- WELL CLUSTER SITE--Site of one or more observation wells completed at different depths. Number is minimum dissolved-oxygen concentration, in milligrams per liter. $\leq$ actual value is less than or equal to value shown; $>$, actual value is greater than value shown; - , no data

Figure 15. Areal distribution of dissolved oxygen in the septage-effluent plume, December 1992. 


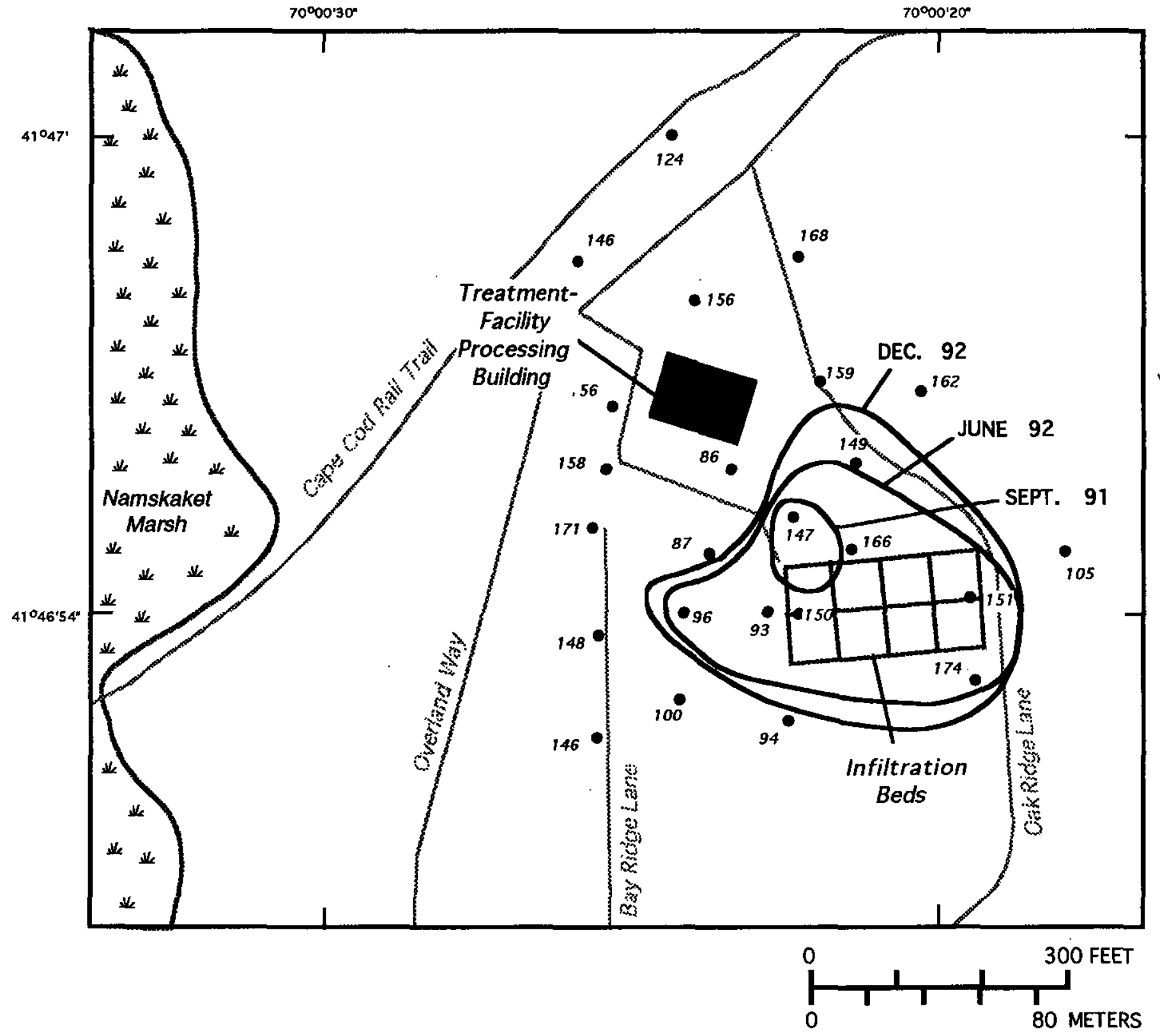

EXPLANATION

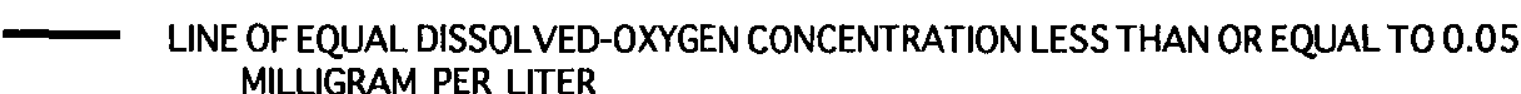

174 WELL CLUSTER SITE-Site of one or more observation wells completed at different depths. Number is site identifier (see table 12)

Figure 16. Areal distribution of anoxic conditions in the septage-effluent plume, September 1991, and June and December 1992. 


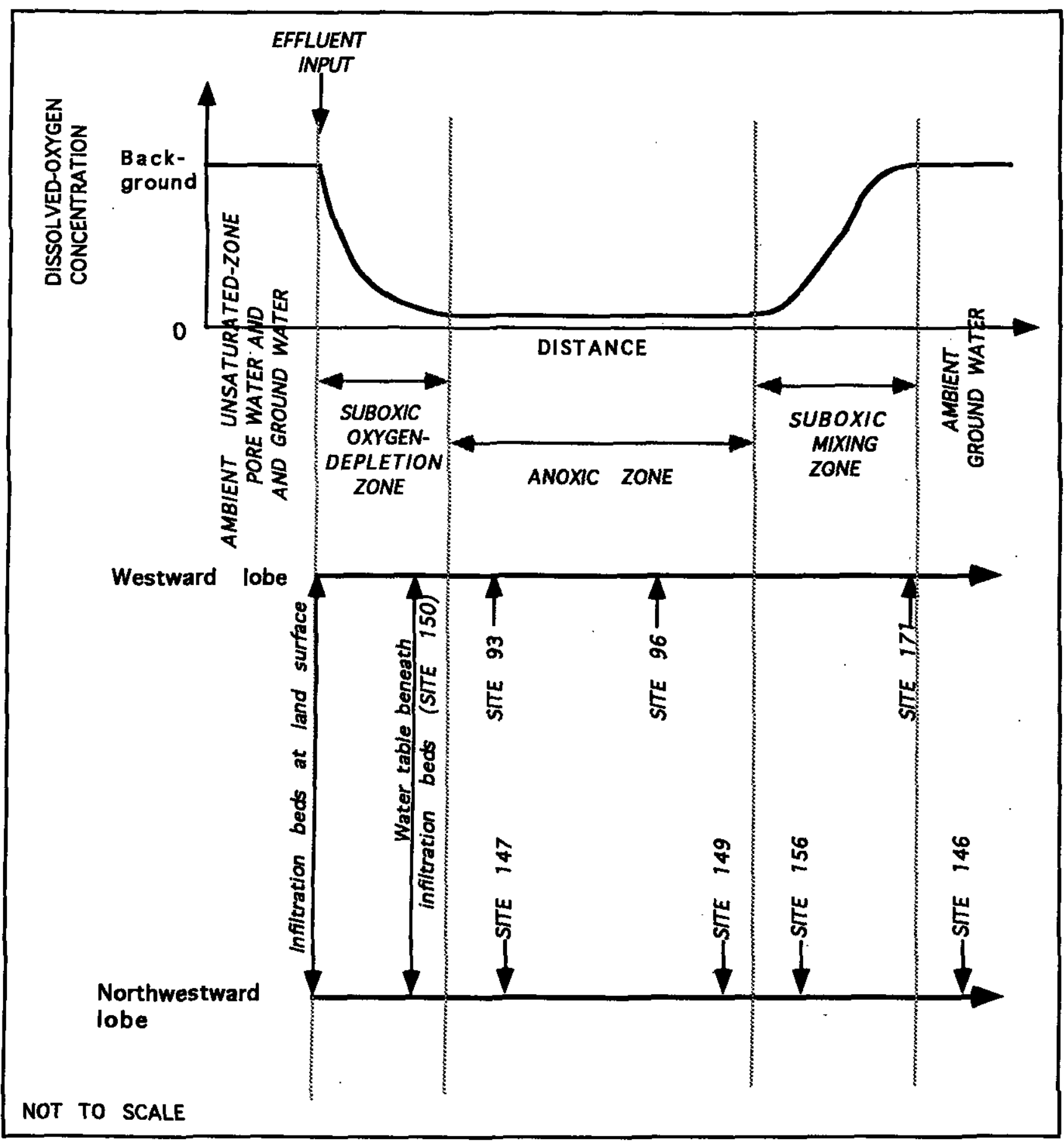

Figure 17. Conceptual model of the development of anoxic conditions in the septage-effluent plume. (After Borden and Bedient, 1986, fig. 1. Location of sites shown in figures 2 and 16.)

anoxic zone are oxidized. This further depletes oxygen at the inner boundary of the mixing zone, and should lead to a sharper boundary than can be explained by dispersion alone. The breakthrough curve for the anoxic zone would, therefore, be steeper than the breakthrough curve of a conservative constituent such as chloride, as apparent at OSW 90, OSW 98, and OSW 107 (figs. 14A, $B$, and $D$ ). 


\section{Nitrogen, Phosphorous, and Organic Carbon}

Concentrations of total dissolved nitrogen in the plume center were greater than $40 \mathrm{mg} / \mathrm{L}$ as $\mathrm{N}$ (table 6) and similar to the median concentration of total nitrogen in effluent (table 4). Most of the nitrogen was in the form of nitrate (table 6). The distribution of nitrate concentrations in December 1992 (fig. 18) and the development of the nitrate plume with time were similar to the chloride and specific conductance plumes. By December 1992, ammonium also was a significant fraction of the total dissolved nitrogen in the center of the plume (fig. 19 and table 6). The distribution of ammonium was related to the distribution of dissolved oxygen. Ammonium concentrations were greater than $1 \mathrm{mg} / \mathrm{L}$ as $\mathrm{N}$ only in the anoxic zone in December 1992 and in the previous synoptic samplings. Nitrite and organic nitrogen, minor constituents of the septage-effluent plume, also were restricted to the anoxic zone (table 6).

Concentrations of phosphorus and dissolved organic carbon were low throughout the septage-effluent plume. Phosphorus concentrations, either as total phosphorus or orthophosphate, were indistinguishable from background concentrations in December 1992 (table 6) and in all synoptic samplings. Concentrations of dissolved organic carbon did not exceed $2.5 \mathrm{mg} / \mathrm{L}$ (fig. 20) and increased slowly from background concentrations $(0.3$ to $0.6 \mathrm{mg} / \mathrm{L})$. The development of the organic carbon plume with time was similar to the development of the ammonium plume and of anoxic conditions with time.

Breakthrough curves of total dissolved nitrogen at five wells (for example, figs. 13A-D) were compared to breakthrough curves of chloride to identify reactive transport of nitrogen (table 7). A reactive process that depleted nitrogen would make nitrogen concentrations increase more slowly than chloride concentrations. Breakthrough curves for nitrogen and chloride were compared in terms of the time required for concentrations to reach one-half of the input concentration. The median concentration of total nitrogen in effluent (46 $\mathrm{mg} / \mathrm{L}$ as $\mathrm{N}$ ) was used as the input concentration. Thus, the breakthrough curves for nitrogen reflect saturatedand unsaturated-zone processes that might affect dissolved or particulate nitrogen. The ratio of time required for nitrogen to reach one-half of the input concentration relative to the corresponding time for chloride ranged from 0.61 to 0.91 (table 7). Therefore, retardation and (or) attenuation of nitrogen in effluent did occur.

\section{Other Constituents and Properties}

Calcium, sodium, and potassium were significant constituents of the septage-effluent plume (table 6) and were distributed similarly to chloride and specific conductance in the aquifer. Magnesium was distributed differently, in that maximum concentrations (about 100 $\mathrm{mg} / \mathrm{L}$ ) were in a zone that encircled the center of the plume. This pattern resulted from transport of magnesium that was desorbed from unsaturated-zone sediments in the first weeks or months of effluent discharge.

The effects of unsaturated-zone processes involving $\mathrm{pH}$, alkalinity, sulfate, silica, and boron also were apparent in the saturated zone (table 6). The $\mathrm{pH}$ was 5.4 in the center of the plume-significantly lower than the $\mathrm{pH}$ of ambient ground water. Concentrations of alkalinity and sulfate, depleted in the unsaturated zone, were lower in the plume than in ambient ground water. In contrast, concentrations of silica in the plume, which increased in the unsaturated zone, were similar to background concentrations and the distribution of silica in the aquifer was fairly uniform. Finally, boron attenuation in the unsaturated zone had become negligible by December 1992. By that time, maximum boron concentrations in the center of the plume were slightly greater than the median boron concentration in effluent.

Water temperatures in the septage-effluent plume were higher than in ambient ground water. Temperatures ranged from 10.1 to $13.1^{\circ} \mathrm{C}$ in December 1992 with a median of $12.1^{\circ} \mathrm{C}$ (table 6). Temperatures as high as $14.3^{\circ} \mathrm{C}$ were measured in June 1992 . The high temperatures in the plume probably resulted from the seasonal pattern of effluent discharge, because more effluent was discharged in the summer when the effluent was warmer than ambient ground water (LeBlanc, 1984).

Breakthrough curves of calcium, sodium, potassium, and boron were compared with breakthrough curves of chloride to identify reactive transport of these constituents (fig. 21). As with breakthrough curves of nitrogen, this comparison includes saturated- and 


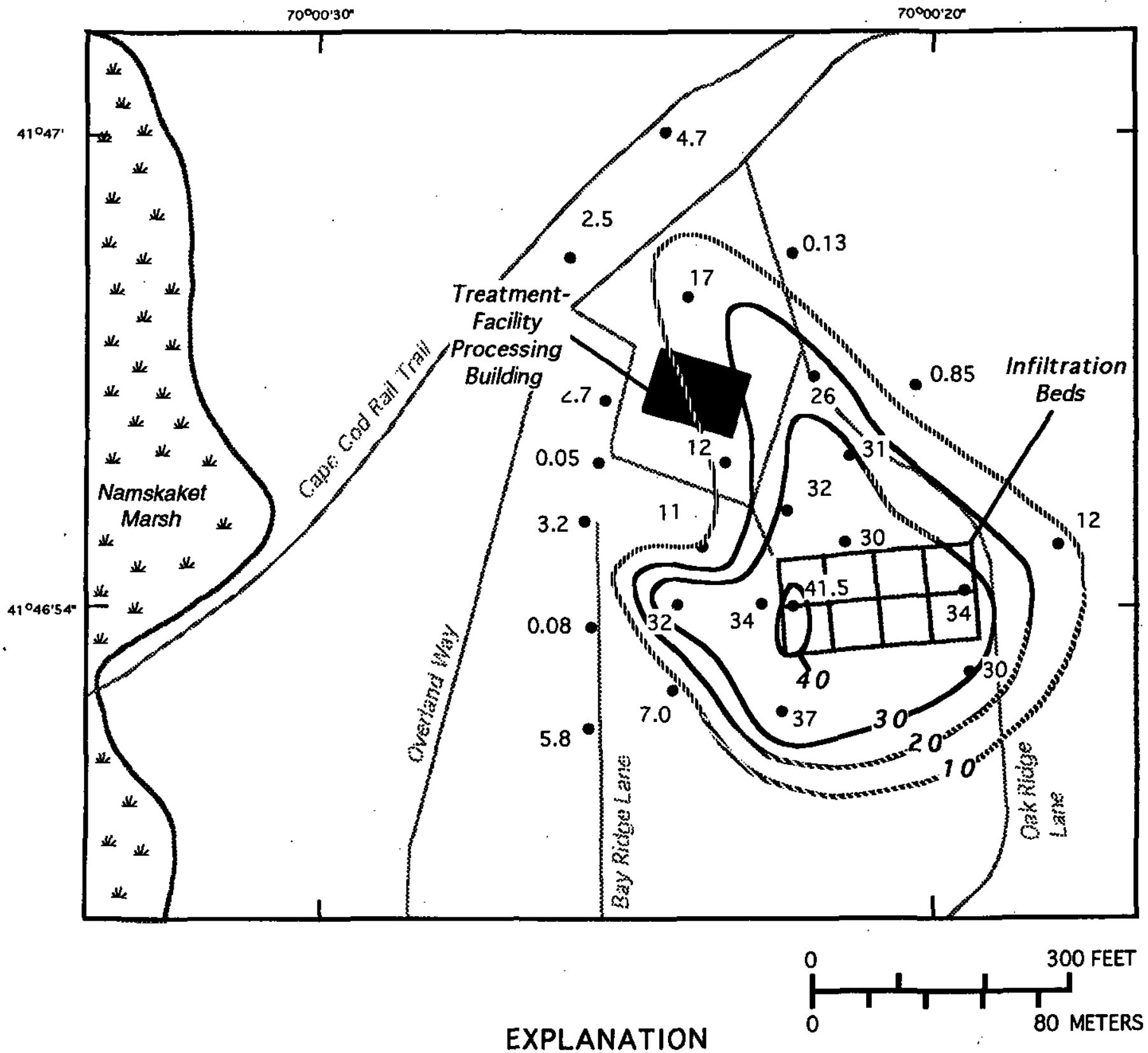

- 10 .......... LINE OF EQUAL NITRATE CONCENTRATION--Dashed where approximately located. interval, 10 milligrams per liter as nitrogen.

30 WELL CLUSTER SITE--Site of one or more observation wells completed at different depths. Number is maximum nitrate concentration, in milligrams per liter as nitrogen

Figure 18. Areal distribution of nitrate in the septage-effluent plume, December 1992. 


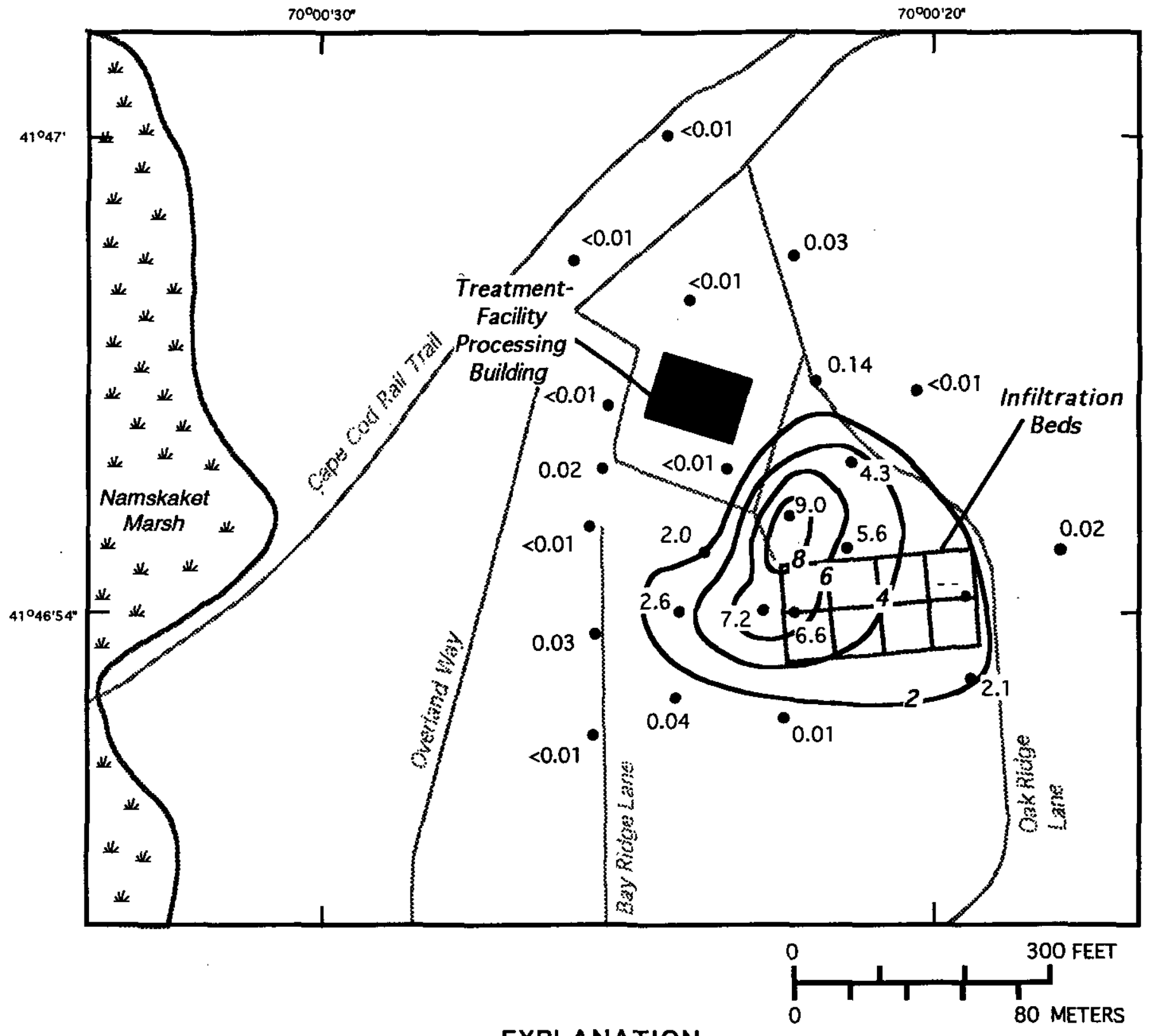

EXPLANATION

-6 - LINE OF EQUAL AMMONIUM CONCENTRATION--Interval, in milligrams per liter as nitrogen, is variable.

2.0 WELL CLUSTER SITE--Site of one or more observation wells completed at different depths. Number is maximum ammonium concentration, in milligrams per liter as nitrogen. $<$, actual value is less than value shown; --, no data

Figure 19. Areal distribution of ammonium in the septage-effluent plume, December 1992. 


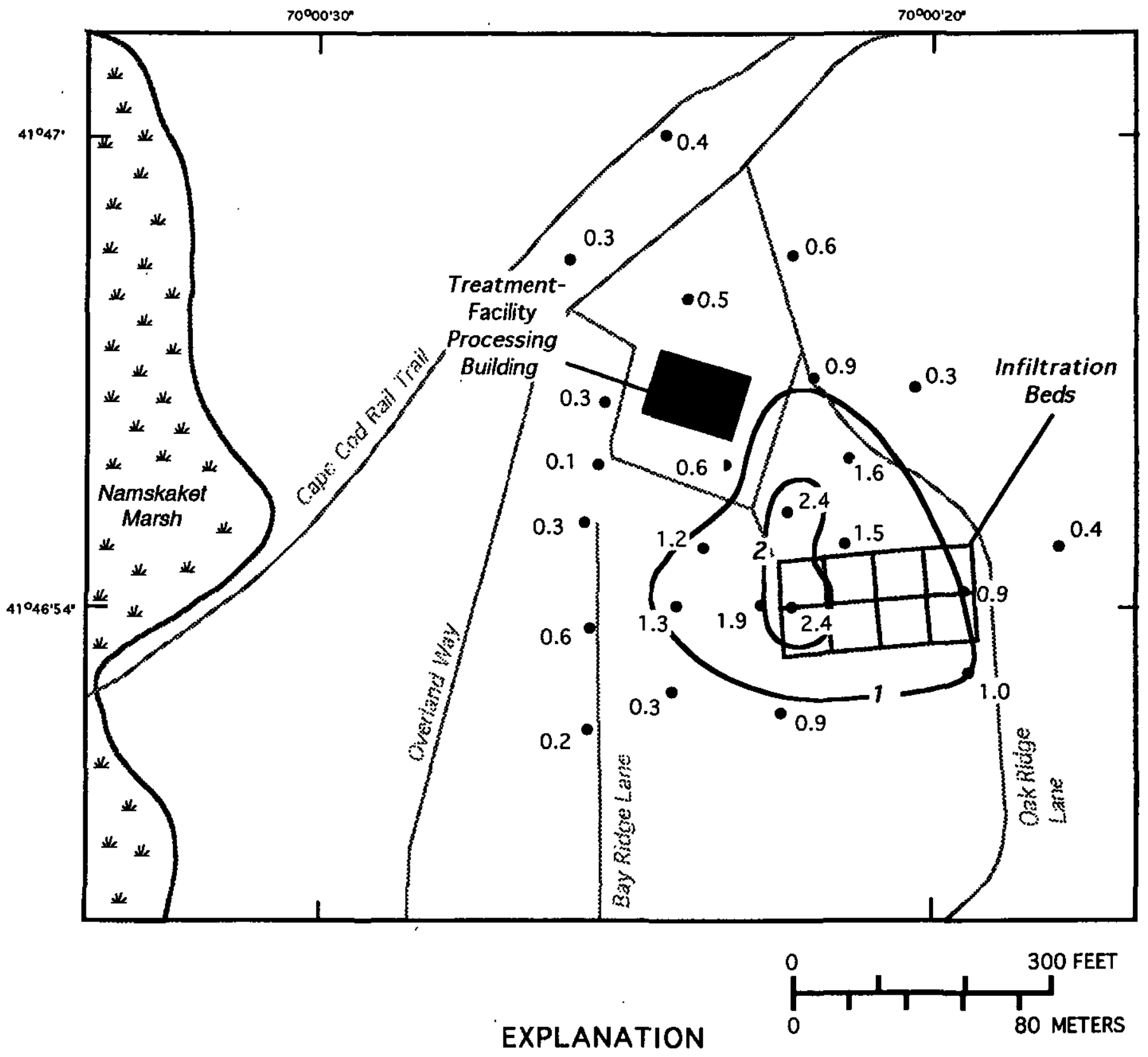

- 1 - LINE OF EQUAL DISSOLVED ORGANIC CARBON CONCENTRATION--Interval, 1 milligram per liter.

0.5 WELL CLUSTER SITE--Site of one or more observation wells completed at different depths. Number is maximum dissolved organic carbon concentration, in milligrams per liter

Figure 20. Areal distribution of dissolved organic carbon in the septage-effluent plume, December 1992. 

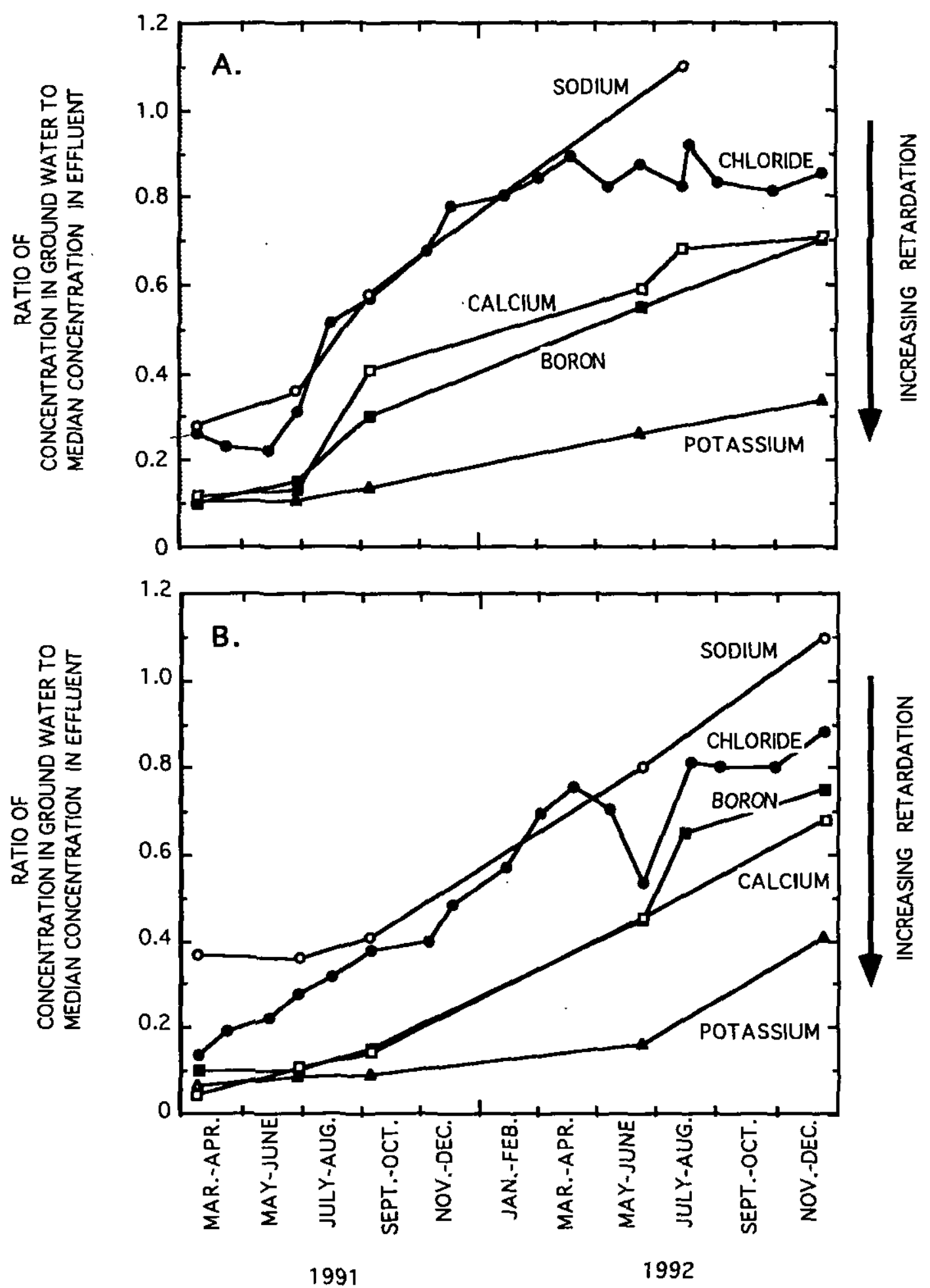

Figure 21. Calcium, sodium, potassium, chioride, and boron in ground water from two wells at site 96 in the westward lobe of the septage-effluent plume. March 1991 through December 1992. (Location of site shown in figures 2 and 10.) A. OSW 98, screened at 47.8 to 48.8 feet below sea level. B. OSW 114 , screened at 26.5 to 27.5 feet below sea level. 
Table 7. Comparison of chloride and nitrogen breakthrough curves at five wells at four sites in the septage-effluent plume

[The breakthrough curve is a plot of concentration and time, where concentration $\left(C / C_{o}\right)$ is the ratio of measured concentration in ground water to median concentration in effluent. The midpoint on the breakthrough curve is the point where $C / C_{o}$ is equal to 0.5 . The velocity of the midpoint is the distance in feet of the saturated-zone flow path to the well divided by the time interval between initiation of effluent discharge and the midpoint of the breakthrough curve, adjusted for the unsaturated-zone traveltime. Locations of cluster sites shown in figure 2; screened intervals of wells listed in table 12]

\begin{tabular}{|c|c|c|c|c|}
\hline \multirow[b]{2}{*}{$\begin{array}{c}\text { Cluster } \\
\text { site }\end{array}$} & \multirow{2}{*}{$\begin{array}{l}\text { USGS well } \\
\text { identifier }\end{array}$} & \multicolumn{2}{|c|}{$\begin{array}{l}\text { Velocity of the } \\
\text { midpoint of the } \\
\text { breakthrough curve }\end{array}$} & \multirow{2}{*}{$\begin{array}{l}\text { Ratio of } \\
\text { nitrogen } \\
\text { to total } \\
\text { chloride } \\
\text { velocity }\end{array}$} \\
\hline & & Chloride & $\begin{array}{l}\text { Nitrogen, } \\
\text { total, } \\
\text { dissolved } \\
\text { (as N) }\end{array}$ & \\
\hline 93 & OSW 90 & 0.20 & 0.17 & 0.85 \\
\hline 96 & OSW 98 & .44 & .25 & .57 \\
\hline 96 & OSW 114 & .32 & .27 & .84 \\
\hline 149 & OSW 107 & .24 & .19 & .79 \\
\hline 156 & OSW 161 & .47 & ${ }^{1} .45$ & .96 \\
\hline
\end{tabular}

${ }^{1}$ Estimated by extrapolation of available data (see figure 14E).

unsaturated-zone processes. Concentrations in ground water from OSW 98 and OSW 114, site 96, were compared. Boron, calcium, and potassium concentrations increased more slowly than chloride and sodium concentrations relative to effluent-input concentrations. The calcium and boron curves are similar, suggesting that calcium and boron were similarly retarded. Both attenuation and conservative transport of boron have been reported during recharge and ground-water transport of secondary level wastewater (Bouwer and others, 1980; Idelovitch and Michail, 1984; LeBlanc, 1984). Boron (as borate) can adsorb to clay minerals, iron oxide and hydroxides; and, although the reaction is most active in alkaline conditions, boron was clearly retarded in the present study despite the generally acid conditions (Keren and Bingham, 1985; McBride, 1994). Retardation of boron and calcium were readily detected in the present study because effluent-input concentrations were measured. Potassium concentrations increased more slowly than either calcium or boron, indicating an even greater degree of retardation. The midpoints of the breakthrough curves for sodium and chloride approximately coincide at both wells. Thus, reactive processes involving sodium were not identified in this analysis.

\section{ESTIMATION OF SOLUTE MASSES IN THE SEPTAGE-EFFLUENT PLUME}

Gains and losses in the total dissolved masses of selected constituents in the plume were determined from effluent-input masses and solute masses in the plume. These mass-balance analyses were based on synoptic samplings of the plume in March, June, and September 1991, and June and December 1992. The mass estimates provided information from which reactive transport processes could be inferred.

\section{Methodology for Estimation of Masses}

Solute masses in the septage-effluent plume were calculated from concentrations in ground water as follows. The total mass of each constituent in the plume can be written as

$$
M=\iiint_{-\infty}^{\infty} n c^{\prime} d x d y d z
$$

where $M$ is the total solute mass, $n$ is porosity, $c^{\prime}$ is solute concentration, and $d x, d y$, and $d z$ are infinitesimal increments of distance in each coordinate direction, $x, y$, and $z$. Solute concentration were measured at discrete sampling points in the aquifer rather than continuously in space. The point concentrations were spatially integrated by first dividing the aquifer near the plume into three-dimensional triangular subdomains. The mass of the solute in each triangular subdomain was then calculated. The total mass in solution for each solute was then determined by summing the contributions from all subdomains. This method is similar to that used by Garabedian and others (1991).

Concentrations in ground water were first vertically integrated at each cluster site. The concentration measured at each well was multiplied by a depth interval within which a uniform concentration was assumed. 
Because the one to six wells at each site provided sparse vertical control on the concentration profile, these depth zones were based on the location of the well screen and the borehole EM log of a deep well at the site. The vertically integrated concentration-depth value (feet-milligrams per liter) was obtained by summing the concentration-depth values from all the wells at the site. An example of the vertical integration scheme is shown in figure 22.

Second, concentration-depth values were horizontally integrated. In each triangular element, concentration-depth values were linearly interpolated among the three cluster sites defining the corners of the triangle, as follows. The solute mass in each triangular element was determined using a method developed for a finite-element integration analysis (Garabedian and others, 1991, p. 915):

$$
\begin{aligned}
& M_{i}=n c_{1} \iint_{\Delta} \varnothing_{1} d x d y+ \\
& \quad n c_{2} \iint_{\Delta} \varnothing_{2} d x d y+n c_{3} \iint_{\Delta} \varnothing_{3} d x d y,
\end{aligned}
$$

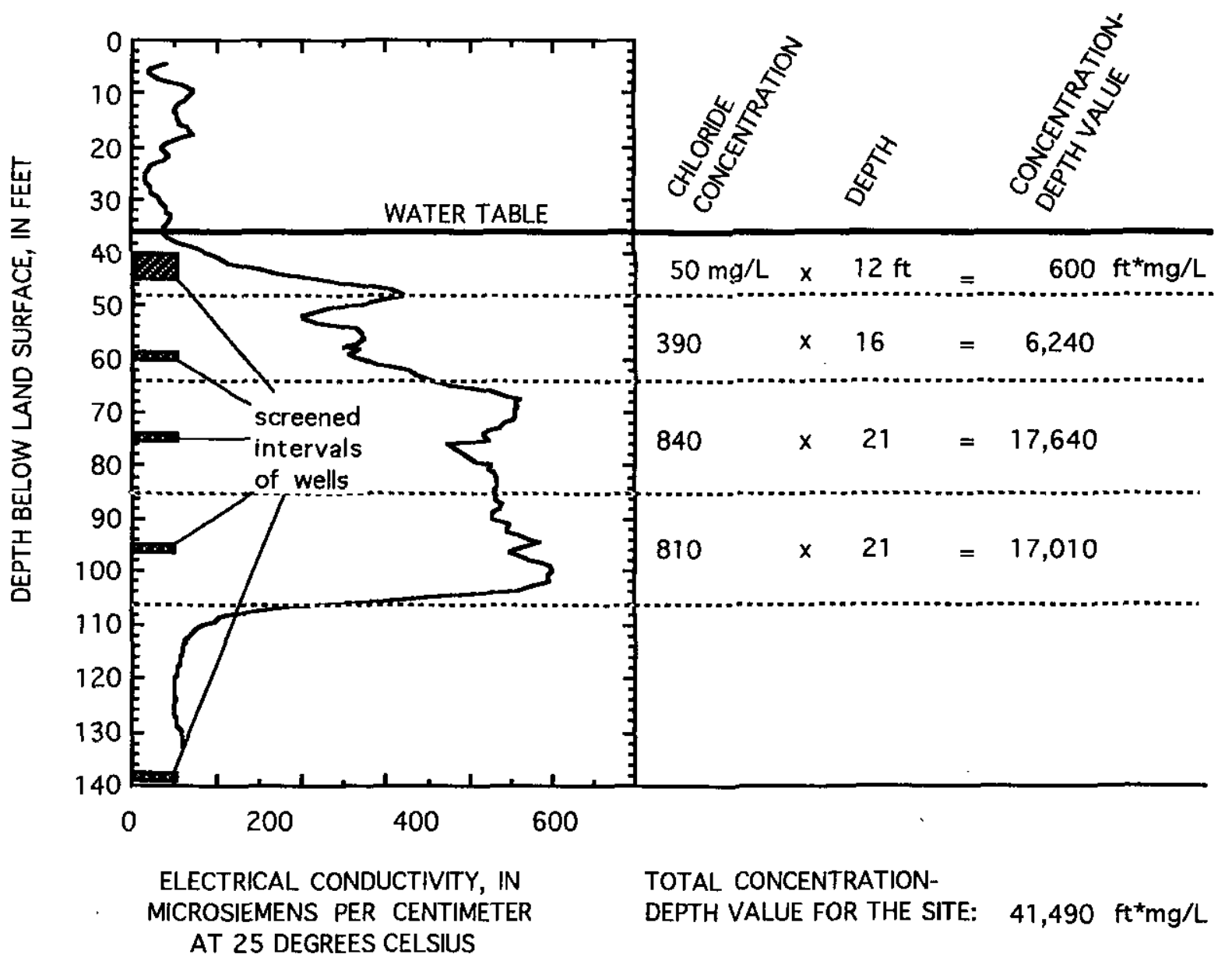

Figure 22. Vertical integration of concentration data for mass-balance calculations. Data shown are from site 96. December 1992. (Location of site shown in figures 2 and $10 . \mathrm{mg} / \mathrm{L}$, milligram per liter; ft, foot; $\mathrm{ft}^{*} \mathrm{mg} / \mathrm{L}$, foot-milligram per liter.) 
where

$$
\begin{aligned}
M_{i}= & \text { mass of solute for triangular element } i \\
c_{1}, c_{2}, c_{3}= & \text { vertically integrated concentration- } \\
& \text { depth value at well sites } 1,2, \text { and } 3 ; \\
n= & \text { porosity, assumed to equal a uniform } \\
& \text { value of } 0.39 ; \\
\varnothing_{1}, \varnothing_{2}, \varnothing_{3}= & \text { linear basis functions which assume a } \\
& \text { value of } 1 \text { at the well site location } \\
& \text { and a value of } 0 \text { at the two } \\
& \text { other well sites; and } \\
\Delta= & \text { areal domain. }
\end{aligned}
$$

Because

$$
\iint_{\Delta} \varnothing_{i} d x d y=\frac{A}{3},
$$

(Zienkiewicz, 1977; also in Garabedian and others, 1991, eq. 14), the solute mass in each triangular element is

$$
M_{i}=\frac{n A}{3}\left(c_{1}+c_{2}+c_{3}\right) \text {, }
$$

where $A$ is the area of each triangular element. $A$ can be calculated using

$$
\begin{array}{r}
A=\frac{1}{2}\left\{\left(x_{2} y_{3}-x_{3} y_{2}\right)-\left(x_{1} y_{3}-x_{3} y_{1}\right)+\right. \\
\left.\left(x_{1} y_{2}-x_{2} y_{1}\right)\right\},
\end{array}
$$

where $\left(x_{1}, y_{1}\right),\left(x_{2}, y_{2}\right)$ and $\left(x_{3}, y_{3}\right)$ are the coordinates of the three cluster sites comprising the corners of each triangular element.

The total mass of each solute in the plume was then determined by summing the contributions from each of the individual elements. A Fortran computer program was written that determines the solute mass in each triangular element and in the entire plume. The triangular elements are shown in figure 23. Integrations for the March, June, and September 1991 synoptic samplings were based on 22 sites and 30 elements. Integrations for the June and December 1992 synoptic samplings were based on 25 sites and 35 elements; the added sites were 124, 146, and 169. Additional sites and elements were included in the 1992 integrations because the plume expanded and new wells were installed.
The solute masses calculated by the triangular integration were corrected for the effects of dispersion. Because of dispersion, the plume (as defined by spatial integration of high-EM-conductivity zones) contained more water than was recharged to the aquifer through the sampling time. The difference between the total water volume in the plume, calculated with the triangular integration, and the cumulative volume of effluent recharge was assumed to equal the volume of ambient ground water incorporated into the plume. Small solute masses corresponding to background concentrations were associated with this ambient water volume. These masses were estimated by multiplying median background concentrations (table 3 ) by the ambient-water volumes and were subtracted from the total solute masses in the plume. Ambient-water masses, as percentages of the total mass estimates, were 0.8 to 3 percent for chloride, 0.4 to 1.6 percent for calcium, 0.8 to 2.2 percent for magnesium, 4.2 to 17 percent for sodium, 2.7 to 14 percent for potassium, 0.1 to 0.5 percent for total nitrogen, 8.8 to 28 percent for dissolved organic carbon, 4.3 to 22 percent for boron, 12 to 29 percent for total phosphorus, and 15 to 64 percent for orthophosphate. Thus, imprecise estimates of ambientwater volumes or concentrations were unlikely to introduce large errors in mass estimates for chloride, calcium, magnesium, potassium, or nitrogen, although they may have been a source of error for other constituents.

The mass of each constituent recharged to the aquifer (effluent-input mass) was computed as follows: (1) Concentrations in biweekly to monthly effluent samples were transformed with a 2-month moving-average technique. This smoothing technique was used to minimize the effect of daily variability in effluent concentrations. (2) The transformed concentrations were assumed to be representative of concentrations in effluent in the days surrounding the sampling date. The time period assigned to each sample was defined by the sampling dates immediately preceding and following the sample. (3) Daily mass inputs were calculated by multiplying daily discharge by the corresponding concentration determined in steps (1) and (2). (4) Daily mass inputs were summed to obtain total mass inputs. The input time period for each synoptic sampling extended from the beginning of discharge to 3 months prior to the sampling date. Thus, the residence time in the unsaturated zone was assumed equal to 3 months, as determined previously. 

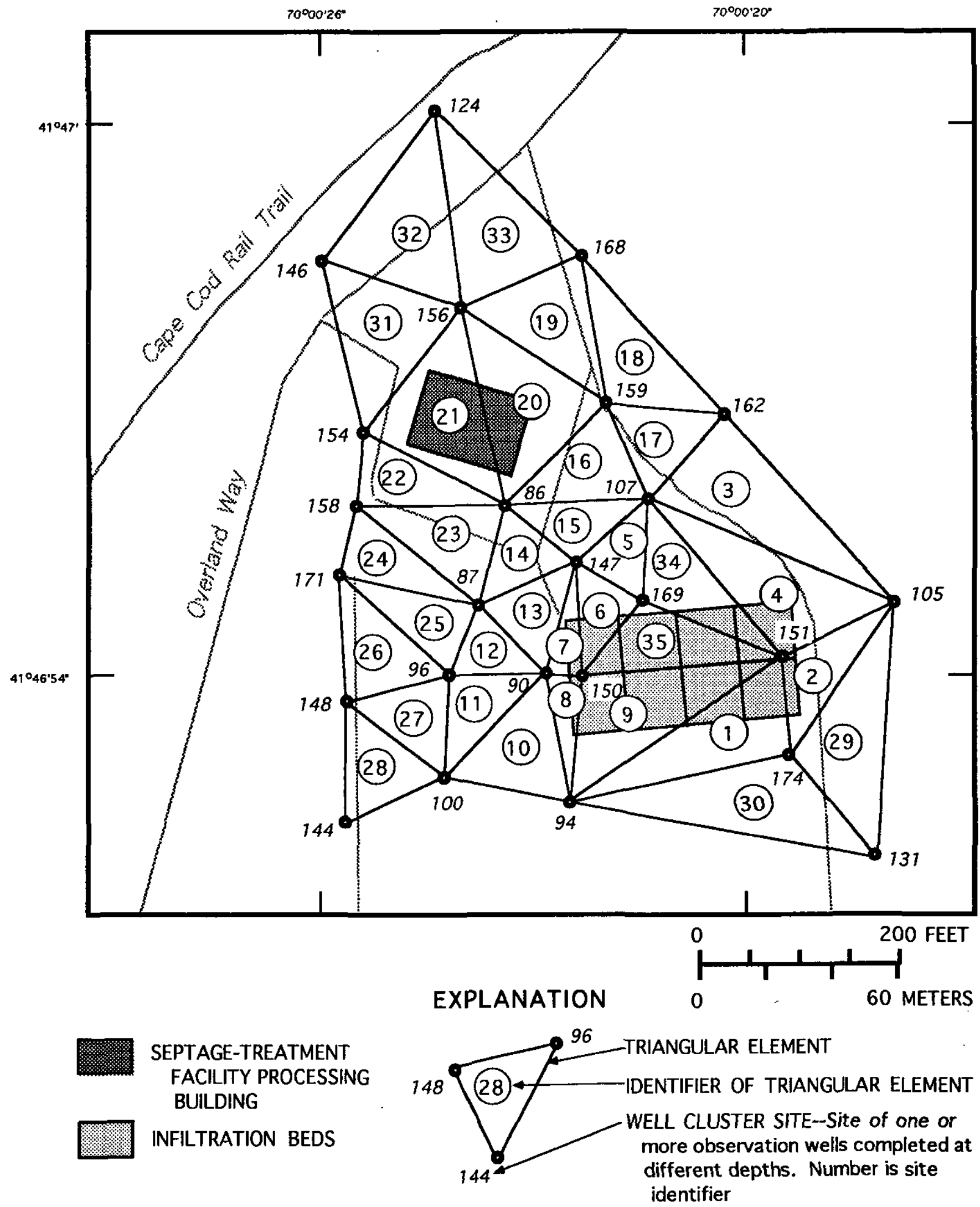

Figure 23. Triangular elements used for mass-balance calculations. 
The effluent-input masses of total nitrogen and organic carbon, including dissolved and particulate forms, were computed as follows. For nitrogen, masses were calculated separately from concentrations of nitrate-, nitrite-, and ammonium-nitrogen, and dissolved organic nitrogen. These species were measured throughout the study. Mass estimates of total (particulate and dissolved) organic nitrogen were then made by multiplying the dissolved-organic-nitrogen masses by 1.8 (the median ratio of total to dissolved organic nitrogen in 15 effluent samples). Nitrate-, nitrite-, and ammonium-nitrogen and total organic nitrogen masses were summed to obtain the total-nitrogen input masses. Total-organic-carbon masses in effluent were similarly calculated using a value of 1.7 (the median ratio of total to dissolved organic carbon in 15 effluent samples).

Minimum and maximum masses were calculated for constituents measured at concentrations less than analytical reporting limits in effluent or ground water. In calculating minimum masses, measurements less than reporting limits were set to zero. For maximum masses, the same measurements were set equal to the reporting limit. This method was applied to total dissolved phosphorus and orthophosphate in effluent and ground water.

\section{Mass of Selected Constituents in Solution}

The estimated solute mass of chloride, the conservative tracer of plume movement, ranged from 46 to 72 percent of the effluent-input masses (table 8). The percentage of chloride masses was highest for the synoptic samples collected in 1992. The recovered percentage of effluent mass increased with time because high-concentration zones in the septage-effluent plume were better defined in later samplings. Improved definition was obtained through installation and sampling of new wells (for example, site 151 in July 1991, fig. 23) and through expansion of the high-concentration zones to intersect more well sites. Freyberg (1986) also found that better definition of the plume center improved recovery in a large-scale tracer test. Sampling-point density was a factor affecting tracer recovery in another large-scale tracer test (Garabedian and others, 1991). However, sampling-point density was relatively constant with time and did not contribute to the increased recovery in the present study.
The observed chloride mass did not reach 100 percent of the input mass. Several factors probably contributed to this. The vertical extent of the plume was well. defined by EM logs at existing cluster sites; however, if wells at a site were not screened in the peak-concentration zones, the concentration-depth value could be underestimated. The horizontal distribution of sampling points was constrained in many areas by obstructions to drilling such as buildings, above-ground structures, roads, and underground structures, pipes and utilities. For example, the high-concentration zone between sites 84,156 , and 159 probably was underestimated (fig. 23). This zone lies beneath the main treatment-facility building where a site could not be installed. A second factor leading to underestimation of chloride mass in the plume was the large variability in plume thickness. Linear interpolation may have underestimated plume thickness between some cluster sites, such as between site 150 (13.5 ft thick) and site 151 (56 ft thick; fig. 23). Finally, the chloride mass may have been underestimated because the plume extended horizontally beyond the observation-well network (Freyberg, 1986). For example, the plume extended eastward past site 105 and southward past site 94 in the later synoptic samplings. This effect is demonstrated by the inclusion of site 131 , which was assigned a concentration-depth value of zero for all constituents at all sampling dates (based on specific conductance measurements). Including site 131 added 5.8 and 6.6 percent to the chloride-mass estimates for June and December 1992. Additional, hypothetical sites with zero concentration-depth values could have been added to improve the solute-mass estimates (Garabedian and others, 1991). However, the sampling-point density of the present study did not justify such a procedure.

Although 100 percent of the chloride in effluent was not recovered, mass-balance analysis could still be used to estimate mass losses or gains of reactive constituents. The factors limiting chloride recovery should similarly affect the calculated masses of all constituents in the plume, because the same sites, wells, and depth intervals were used for all constituents. In the absence of attenuating processes, solute masses (as percentages of the effluent-input masses) should be similar to chloride masses. Therefore, solute masses in each sampling were normalized to the chloride mass recovered in that sampling to identify reactive losses or gains (table 8 ). If the distribution of a constituent was significantly different from the chloride distribution, especially where the 
Table 8. Effluent-input masses and solute masses in the septage-effluent plume, March, June, and September 1991, and June and December 1992

[Effluent-input masses equal the cumulative masses recharged to the aquifer, excluding masses in transit in the unsaturated zone]

\begin{tabular}{|c|c|c|c|c|c|}
\hline \multirow{2}{*}{ Constituent } & \multicolumn{5}{|c|}{ Date of synoptic sampling } \\
\hline & Mar. 1991 & June 1991 & Sept. 1991 & June $19 \overline{9}$ & Dec. 1992 \\
\hline \multicolumn{6}{|c|}{ Effluent-input masses, in kilograms } \\
\hline 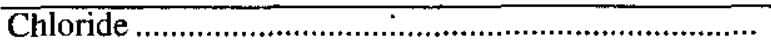 & 24,000 & 28,000 & 31,000 & 47,000 & 66,000 \\
\hline Calcium & 12,000 & 14,000 & 15,000 & 22,000 & 30,000 \\
\hline Magnesium & 150 & 160 & 160 & 170 & 180 \\
\hline Sodium & 1,700 & 2,000 & 2,300 & 4,700 & 6,900 \\
\hline Potassium & 500 & 600 & 700 & 1,300 & 1,900 \\
\hline Nitrogen, total (as N) ${ }^{1}$ & 980 & 1,200 & 1,300 & 2,200 & 3,300 \\
\hline 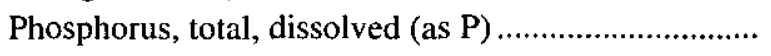 & 3.2 & 4.4 & 6.1 & 41 & 53 \\
\hline Phosphorus, dissolved, orthophosphate (as P).............. & $1.8-2.0$ & 2.4-2.6 & $3.5-3.7$ & 31 & 37 \\
\hline 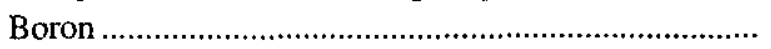 & 5.5 & 6.0 & 6.5 & 11 & 15 \\
\hline 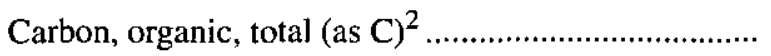 & 570 & 770 & 880 & 1,400 & 2,000 \\
\hline \multicolumn{6}{|c|}{ Solute masses in the septage-effluent plume, in kilograms } \\
\hline 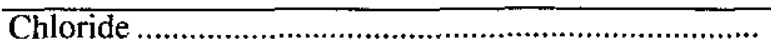 & 12,000 & 13,000 & 19,000 & 34,000 & 47,000 \\
\hline Calcium & 3,200 & 3,100 & 5,800 & 11,000 & 15,000 \\
\hline 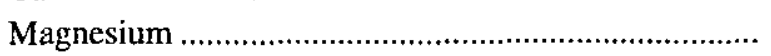 & 1,600 & 1,700 & 2,700 & 3,900 & 4,500 \\
\hline Sodium & 1,400 & 1,400 & 2,100 & 4,200 & 5,900 \\
\hline Potassium & 110 & 120 & 210 & 450 & 750 \\
\hline 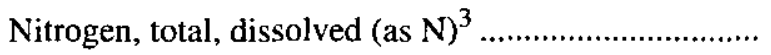 & 300 & 380 & 720 & 1,400 & 2,000 \\
\hline 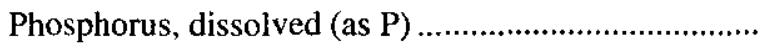 & $0.6-0.7$ & 0.9 & $1.3-1.4$ & 1.4-1.6 & $1.5-1.6$ \\
\hline Phosphorus, dissolved, orthophosphate (as P).............. & $0.2-0.5$ & 0.6 & $0.3-0.6$ & $1.0-1.2$ & 2.0 \\
\hline 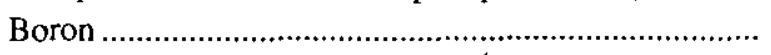 & 1.1 & 1.1 & 2.0 & 5.0 & 7.6 \\
\hline 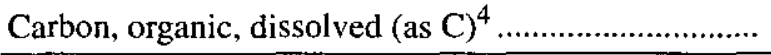 & 23 & 21 & 29 & 48 & 71 \\
\hline \multicolumn{6}{|c|}{ Solute masses in the septage-effluent plume, as percentage of effluent-input masses } \\
\hline 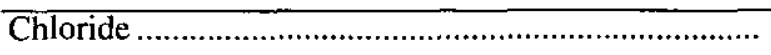 & 50 & 46 & 61 & 72 & 71 \\
\hline 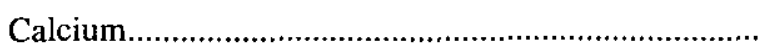 & 27 & 22 & 39 & 50 & 50 \\
\hline 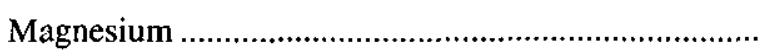 & 1,100 & 1,100 & 1,700 & 2,300 & 2,500 \\
\hline Sodium & 82 & 70 & 91 & 88 & 86 \\
\hline Potassium & 22 & 20 & 30 & 35 & 39 \\
\hline 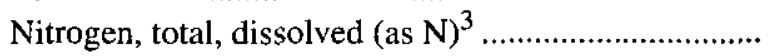 & 31 & 32 & 55 & 64 & 61 \\
\hline 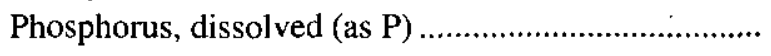 & $19-22$ & 20 & $21-23$ & 3.4-3.9 & $2.8-3.0$ \\
\hline Phosphorus, orthophosphate, dissolved (as P) ............ & $11-25$ & $23-25$ & $8.6-16$ & $3.2-3.9$ & 5.4 \\
\hline Boron & 20 & 18 & 31 & 45 & 51 \\
\hline 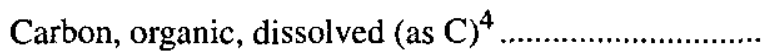 & 4.0 & 2.7 & 3.3 & 3.4 & 3.6 \\
\hline
\end{tabular}

plume was not well defined, the mass of the constituent may have been under- or overestimated differently than the chloride mass. This error would have been small for total nitrogen, calcium, and sodium, which were closely correlated with chloride in all sampling rounds (total nitrogen, $R^{2}=0.80$ to 0.94 ; calcium, $R^{2}=0.91$ to 0.95 ; and sodium, $R^{2}=0.87$ to 0.95$)$. Potassium $\left(R^{2}=0.71\right.$ to $0.76)$, boron $\left(R^{2}=0.35\right.$ to 0.83$)$, dissolved organic carbon $\left(R^{2}=0.65\right.$ to 0.81$)$, and magnesium $\left(R^{2}=0.35\right.$ to $0.88)$ were less well correlated with chloride and may 
Table 8. Effluent-input masses and solute masses in the septage-effluent plume, March, June, and September 1991, and June and December 1992-Continued

\begin{tabular}{|c|c|c|c|c|c|}
\hline \multirow{2}{*}{ Constituent } & \multicolumn{5}{|c|}{ Date of synoptic sampling } \\
\hline & Mar. 1991 & June 1991 & Sept. 1991 & June 1992 & Dec. 1992 \\
\hline \multicolumn{6}{|c|}{ Solute masses in the septage-effluent plume, as a percentage of effluent-input masses, normalized to chloride masses } \\
\hline 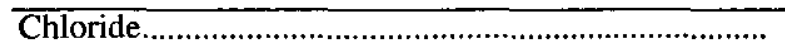 & 100 & 100 & 100 & 100 & 100 \\
\hline 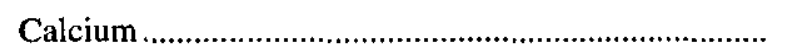 & 54 & 48 & 64 & 69 & 70 \\
\hline 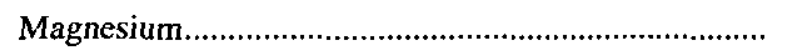 & 2,200 & 2,400 & 2,800 & 3,200 & 3,500 \\
\hline Sodium & 160 & 150 & 150 & 120 & 120 \\
\hline Potassium & 44 & 43 & 49 & 49 & 55 \\
\hline Nitrogen, total, dissolved (as $\mathrm{N})^{3} \ldots \ldots \ldots \ldots \ldots \ldots \ldots \ldots \ldots \ldots \ldots \ldots$ & 62 & 70 & 90 & 89 & 86 \\
\hline 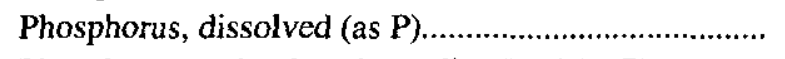 & $40-42$ & 44 & $34-38$ & $4.7-5.4$ & $3.9-4.2$ \\
\hline Phosphorus, orthophosphate, dissolved (as P) ................ & $24-50$ & $49-62$ & $14-28$ & $4.4-5.4$ & 7.5 \\
\hline Boron & 40 & 40 & 51 & 63 & 71 \\
\hline 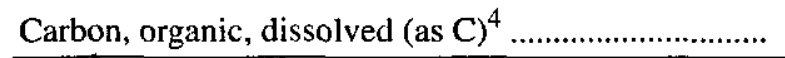 & 8.0 & 5.9 & 5.4 & 4.7 & 5.1 \\
\hline $\begin{array}{l}\text { Total nitrogen equals the sum of nitrate-, nitrite-, } \\
\text { organic nitrogen. Particulate organic nitrogen in effluent } \\
\text { in } 15 \text { samples. } \\
{ }^{2} \text { Total organic carbon is equal to the sum of partic } \\
\text { effluent estimated from measurements of total and diss } \\
{ }^{3} \text { Total dissolved nitrogen equals the sum of nitrate } \\
\text { ticulate organic nitrogen in ground water assumed to eq } \\
{ }^{4} \text { Particulate organic carbon in oroun water }\end{array}$ & $\begin{array}{l}\text { ind ammoniu } \\
\text { estimated fro } \\
\text { late and diss } \\
\text { lved organic } \\
\text { nitrite-, am } \\
\text { al zero. }\end{array}$ & $\begin{array}{l}\text { m-nitrogen, } \\
\text { n measurem } \\
\text { olved organi } \\
\text { carbon in } 15 \\
\text { nonium-nitr }\end{array}$ & $\begin{array}{l}\text { ssolved orga } \\
\text { ts of total an } \\
\text { carbon. Parti } \\
\text { amples. } \\
\text { gen, and diss }\end{array}$ & $\begin{array}{l}\text { nitrogen, an } \\
\text { lissolved org } \\
\text { late organic }\end{array}$ & $\begin{array}{l}\text { particulate } \\
\text { lic nitrogen } \\
\text { rogon in } \\
\text { rogen. Par- }\end{array}$ \\
\hline
\end{tabular}

have been affected by this error. In general, the normalized constituent masses provided our best estimates of the actual mass losses or gains. Finally, the losses or gains estimated by this method included saturated- and unsaturated-zone processes, as in the breakthroughcurve analysis.

The dissolved masses of nitrogen, phosphorus, and organic carbon in the plume (table 8 ) suggest loss of these constituents from solution. Total-dissolvednitrogen masses, normalized to chloride, were 62 to 90 percent of the total-nitrogen masses in effluent. The mass decrease in nitrogen, which includes losses of particulate and dissolved forms, appeared to be larger than the unsaturated-zone attenuation affecting dissolved forms, which was indistinguishable from dilution. Dissolved-organic-carbon masses were less than 10 percent of the effluent-input masses. Masses of total dissolved phosphorus and orthophosphate in the plume also were uniformly low. The large increase in the phosphorus input masses between September 1991 and June 1992 (table 8) had little noticeable effect on phosphorus concentrations or masses in the plume.
Solute masses of calcium, magnesium, sodium, potassium, and boron in the plume differed from the input masses, apparently due to sorption and(or) ion exchange (table 8). Normalized calcium masses, 48 to 70 percent of input masses, were less than expected from unsaturated-zone attenuation alone (about 14 percent after dilution). Calcium loss, therefore, also may have occurred in the saturated zone, and the loss represented a smaller fraction of the total calcium mass with time. Expressed in equivalents, the mass losses in calcium were 84 to 114 percent of mass gains in magnesium (fig. 24). The good agreement suggests that the primary mechanism responsible for these changes is calcium-magnesium exchange on sediments, as postulated previously. Normalized sodium masses in the plume were 170 to 120 percent of effluent masses. These values suggest an increase in sodium that was not apparent in the unsaturated-zone analysis; the sodium gain seemed to decrease with time relative to the total sodium mass. Mass decreases in potassium, expressed as equivalents, were only 16 to 39 percent of increases in sodium, suggesting that these changes were not closely coupled (fig. 24). If sodium is input to the plume 


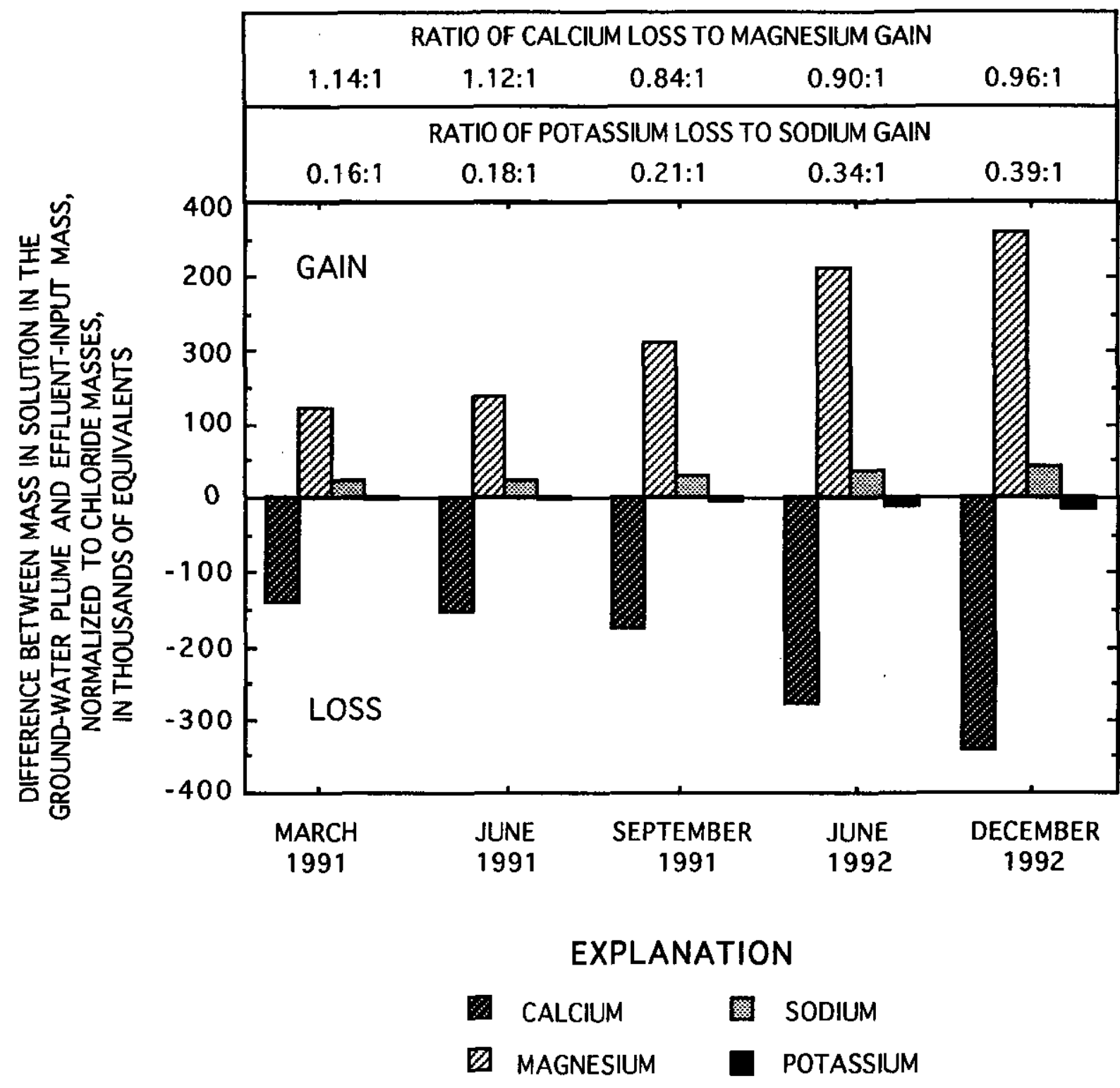

Figure 24. Differences between cation masses in the septage-effluent plume and masses input to the aquifer in effluent. Positive difference represents increase in mass (gain). Negative difference represents decrease in mass (loss).

through cation exchange, it must be displaced at least in part by some ion(s) other than potassium. The increase in sodium may be related to a loss from solution of ammonium or hydrogen ions. Dissolution of plagioclase feldspar also may be a source of sodium. Finally, normalized boron masses were 40 to 71 percent of effluent-input masses, and increased with time. This represents a total decrease of about 30 to 60 percent of effluent boron and is about twice the unsaturated-zone attenuation. Therefore, the mechanism for boron removal (perhaps boron adsorption as borate) likely also occurred in the saturated zone. 
In summary, the mass-balance analysis of dissolved constituents in the plume has verified the changes in effluent quality identified in the unsaturatedzone analysis. The mass-balance analysis also showed that (1) losses of effluent nitrogen and organic carbon occurred, either through unsaturated-zone attenuation of particulate nitrogen or through other saturated-zone attenuation processes; (2) calcium-and-magnesium exchange and boron sorption occurred in the saturated zone as well as in the unsaturated zone; and (3) sodium was not transported conservatively but was gained from aquifer sediments, probably in the saturated zone.

\section{REACTIVE PROCESSES INVOLVING NITROGEN IN THE SEPTAGE-EFFLUENT PLUME}

The fate and transport of effluent nitrogen through the unsaturated zone and in the septage-effluent plume was controlled by microbial transformation processes as well as by the physical and chemical processes that affect other constituents in the plume. Microbial processes can affect the mobility and ultimate fate of the nitrogen by altering its speciation. Nitrogen concentrations in effluent and ground water indicate that ammonification and nitrification occurred in the unsaturated zone and prior to discharge during the treatment process. Nitrate was the primary nitrogen form in the septage-effluent plume, and smaller amounts of ammonium also were present. In the saturated zone, the processes most likely to attenuate nitrogen concentrations were ammonium sorption and denitrification of nitrate. These processes were measured directly in the present study, and mass estimates of ammonium sorption and denitrification were made. Finally, reactive processes involving nitrogen were summarized in a nitrogen budget for the plume during the study.

\section{Ammonium Sorption}

Ammonium sorption was measured with batch tests, sediment extractions, and mass-balance estimates. Batch tests were used to derive sorption models, or mathematical relations between equilibrium concentrations of dissolved and sorbed ammonium in aquifer sediments. Field applicability of the models was tested by comparing quantities predicted by the sorption models with measurements of extractable ammonium in sediments in the plume. Mass estimates of sorbed ammonium in sediments in the plume were then made using the best sorption model and dissolved-ammonium concentrations in ground water.

\section{Batch Tests}

Batch tests were conducted with uncontaminated samples (dissolved ammonium less than or equal to about $0.10 \mathrm{mg} / \mathrm{L}$ as $\mathrm{N}$ ) of silty fine to medium sand from the upper fine-grained lithologic units (tests 1 and 2) and the intermediate coarse-grained unit (tests $3 \mathrm{a}$ and $3 b)$. The equilibrium relation between concentrations of sorbed and dissolved ammonium was curvilinear for the tested range of dissolved concentrations (fig. 25). The relation was more nearly linear at low concentrations and in the artificial-effluent test (test $3 b$ ). There was little difference among the tests with ambient ground water and with double-distilled water (test 1,2 , and 3a, henceforth referred to as "low-ionic-strength tests"). This is not unexpected because the ambient ground water had a low-ionic strength and dissolved-solids concentration $(70 \mathrm{mg} / \mathrm{L})$. In contrast, sorbed concentrations in the artificial-effluent test (test $3 \mathrm{~b}$ ), were about one-third to one-half of the sorbed concentrations in the distilled-water test with the same sediment sample (test $3 a)$. The difference resulted from the ionic strength of the artificial-effluent solution, which was more than 30 times greater than that of the ambient ground water. Calcium and sodium ions in the artificial-effluent solution competed with the ammonium ions for sediment-sorption sites. Consequently, ammonium sorption was less from the artificial-effluent solution than from the lowionic-strength solutions.

The batch-test data were fit to three widely used sorption models, the linear, Freundlich, and Langmuir models, to determine an equation that best describes the data. In the linear model, the sorbed concentration is directly proportional to the dissolved concentration, or

$$
S=K_{D} \times C,
$$

where $S$ is the mass of solute adsorbed per unit dry mass of sediment, $C$ is the dissolved concentration, and $K_{D}$ is a constant. $K_{D}$, the linear distribution coefficient, is equal to the slope of a straight-line relation between sorbed and dissolved concentrations (Hem, 1985, p. 28). This model implies constant partitioning between sorbed and dissolved phases, 


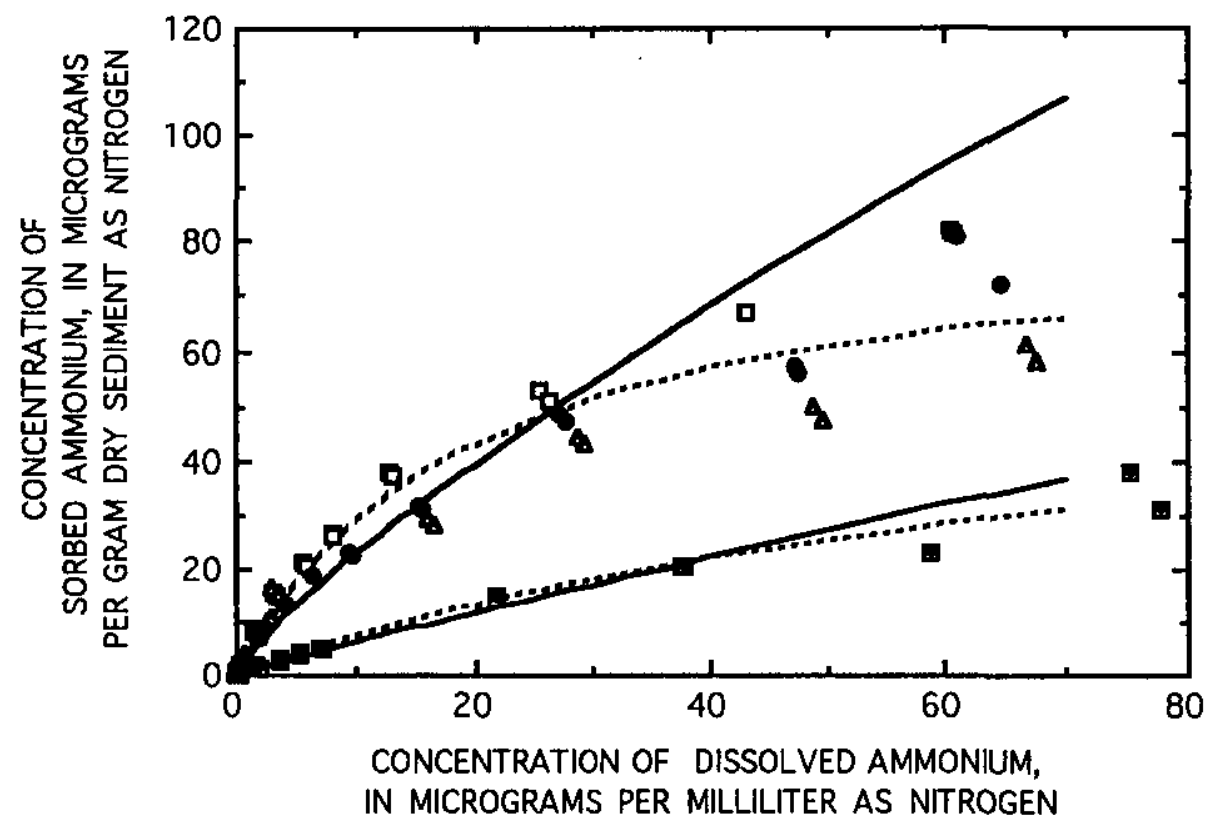

EXPLANATION

FREUNDLICH ISOTHERM

LANGMUIR ISOTHERM
- TEST 1--Ambient ground water

- TEST 2--Ambient ground water

\ TEST 3a--Double-distilled water

- TEST 3b--Artificial-effluent solution

Figure 25. Ammonium-sorption data from batch tests and calculated isotherms using Freundlich and Langmuir sorption models. Isotherms shown for ambient ground water and tests calculated from pooled data of tests 1,2 , and $3 a$.

which is independent of dissolved concentration. The linear isotherm was not appropriate for the full concentration range in the low-ionic strength tests, but was applicable at low concentrations (less than 2.0 $\mathrm{mg} / \mathrm{L}$ as $\mathrm{N}$ ) for these tests and for concentrations as much as $22 \mathrm{mg} / \mathrm{L}$ as $\mathrm{N}$ for the artificial-effluent test.

In the Freundlich and Langmuir models, partitioning between sorbed and dissolved phases depends on the dissolved concentration such that sorption decreases with increasing dissolved concentration. The
Freundlich isotherm predicts that the sorbed concentration is proportional to a power function of the dissolved concentration,

$$
S=K_{D} \times C^{b}
$$

or

$$
\log S=\log K_{D}+b \log C
$$


where $C$ and $S$ are as defined above and $K_{D}$ and $b$ are constants. When $b$ is equal to 1 , the Freundlich isotherm is equivalent to the linear isotherm and $K_{D}$ is the linear distribution coefficient. The constant, $b$, equals the slope of a linear plot of $\log (S)$ versus $\log (C)$, and $K_{D}$ is the antilog of the intercept (Freeze and Cherry, 1979, p. 403). The goodness-of-fit of the model can be evaluated by means of the $R^{2}$ of this linear relation.

The Langmuir model includes parameters describing the maximum sorption capacity of the solid material, according to the equation,

$$
\frac{C}{S}=\frac{1}{k_{2}} C+\frac{1}{k_{1} k_{2}},
$$

where $C$ and $S$ are as defined previously, $k_{1}$ is a constant related to the bonding energy between the solid surface and ion, or to the ratio of bonding energies of the sorbed ion and the desorbed ion it replaces, and $k_{2}$ is a constant describing the maximum adsorption capacity of the solid (Harter and Baker, 1977; Fetter, 1988, p. 347). The goodness-of-fit of the Langmuir isotherm can be determined from a plot of $C / S$ versus $C$, which will be linear if the model applies (Veith and Sposito, 1977). The constant $k_{2}$ equals the inverse of the slope of the best-fit line to this plot. The constant $k_{1}$ can be evaluated from $k_{2}$ and the intercept of the best-fit line.

Following the criteria described, linear regression was used to fit the three sorption models to the batchtest data and to determine the model constants (table 9). $R^{2}$ values were all high. The best-fit Freundlich and Langmuir isotherms are shown in figure 25. A single pair of curves represents the low-ionic-strength tests, which were obtained by combining data from all three tests. The Freundlich models overestimate sorbed concentrations at high dissolved concentrations and

Table 9. Linear, Freundlich, and Langmuir sorption models fit to batch-test data for ammonium sorption

[Sorption models for all three low-ionic-strength tests obtained by combining data from tests 1,2, and 3a prior to regression analysis. $S$, sorbed concentration in micrograms per gram of dry sediment $(\mu \mathrm{g} / \mathrm{g}) ; C$, dissolved concentration in micrograms per milliliter; $K_{D}, k_{1}, k_{2}$, constants, as defined; $\mathrm{NH}_{4}-\mathrm{N}$, ammonium-nitrogen. $\mathrm{mg} / \mathrm{L}$, milligram per liter; $\mathrm{mL} / \mathrm{g}$, milliliter per gram of dry sediment; $\mathrm{mL} / \mathrm{\mu g}$, milliliter per microgram; $R^{2}$, coefficient of determination. --, no data]

\begin{tabular}{|c|c|c|c|c|c|}
\hline \multirow{2}{*}{ Sorption model } & \multicolumn{4}{|c|}{ Low-ionic-strength tests } & \multirow{2}{*}{$\begin{array}{l}\text { Artificial } \\
\text { effluent test } \\
\text { test } 3 b\end{array}$} \\
\hline & Test 1 & Test 2 & Test 3a & All three tests & \\
\hline \multicolumn{6}{|c|}{ Linear Model: $S=K_{D} \times C$} \\
\hline \multicolumn{6}{|l|}{$\mathrm{NH}_{4}-\mathrm{N} 0$ to $2 \mathrm{mg} / \mathrm{L}$} \\
\hline$K_{D}(\mathrm{~mL} / \mathrm{g})$ & 6.4 & 3.7 & 3.6 & 4.1 & 0.88 \\
\hline Intercept $(\mu \mathrm{g} / \mathrm{g}$ as $\mathrm{N})$ & .093 & .27 & .10 & .18 & .020 \\
\hline$R^{2}$ & .998 & .989 & .990 & .912 & .951 \\
\hline \multicolumn{6}{|l|}{$\mathrm{NH}_{4}-\mathrm{N} 0$ to $22 \mathrm{mg} / \mathrm{L}$} \\
\hline$K_{D}(\mathrm{~mL} / \mathrm{g})$ & - & -- & -- & - & .66 \\
\hline . Intercept $(\mu \mathrm{g} / \mathrm{g}$ as $\mathrm{N}) \ldots \ldots \ldots \ldots$ & -- & -- & -- & -- & .22 \\
\hline$R^{2}$ & -- & -- & -- & -- & .997 \\
\hline \multicolumn{6}{|c|}{ Freundlich Model: $S=K_{D} \times C^{b}$, or $\log S=\log _{D}+b \log C$} \\
\hline \multicolumn{6}{|l|}{$\mathrm{NH}_{4}-\mathrm{N} 0$ to $22 \mathrm{mg} / \mathrm{L}$} \\
\hline$K_{D}(\mathrm{~mL} / \mathrm{g})$ & 4.5 & 3.7 & 2.8 & 3.6 & 0.76 \\
\hline$b$ (dimensionless) $\ldots . . . \ldots \ldots \ldots . . . . .$. & .79 & .77 & .83 & .80 & .91 \\
\hline$R^{2}$ & .976 & .990 & .950 & .963 & .984 \\
\hline \multicolumn{6}{|c|}{ Langmuir Model: $C / S=1 / k_{2} C+1 / k_{1} k_{2}$} \\
\hline \multicolumn{6}{|l|}{$\mathrm{NH}_{4}-\mathrm{N} 0$ to $22 \mathrm{mg} / \mathrm{L}$} \\
\hline$k_{1}(\mathrm{~mL} / \mathrm{g}$ as $\mathrm{N})$ & 0.062 & 0.050 & 0.045 & 0.052 & 0.013 \\
\hline$k_{2}(\mu \mathrm{g} / \mathrm{g}$ as $\mathrm{N})$ & 96 & 88 & 75 & 84 & 65 \\
\hline$R^{2}$ & .953 & .910 & .801 & .801 & .618 \\
\hline
\end{tabular}


underestimate sorbed concentrations at low concentrations, although the deviation is small in the artificialeffluent test. The Langmuir isotherm best describes the low-ionic-strength test data. The high $R^{2}$ values for the Freundlich isotherm, which were higher than the Langmuir values, apparently were artifacts of the log$\log$ correlation $(\log S$ compared to $\log C$ ). For the artificial-effluent test, all three sorption models fit the data well.

The Langmuir model also can be used to predict the maximum adsorption capacity or CEC of the sediment samples, which is described by the constant $k_{2}$ (Hunt and Adamsen, 1985). Values of this constant correspond to CEC's of $0.7,0.6$, and $0.5 \mathrm{meq} / 100 \mathrm{~g}$ for tests 1,2 , and $3 \mathrm{a}$, respectively. These CEC estimates generally are comparable to measured values for aquifer sediments, which ranged from 0.5 to $2.0 \mathrm{meq} / 100 \mathrm{~g}$ (table 2 ). They are lower than the CEC values of samples with similar amounts (20 to 30 percent) of silt and clay as the batch-test sediment samples.

\section{Field Applicability of the Batch-Test Sorption Models}

The use of batch-test sorption models to quantify sorption in the plume requires several assumptions. First, batch tests represent chemical and physical equilibrium conditions. Thus, field conditions must meet the local equilibrium assumption. This assumption states that sorption reaction rates and any intrapore transport processes controlling the reaction rate are rapid relative to the rate of ground-water flow (Valocchi, 1985). Second, applying one batch-test model to the entire plume assumes that sorbed concentrations in sediments are controlled primarily by dissolved concentrations. Variation in the concentrations of other ions and in sediment characteristics must be negligible relative to the variation in dissolved concentrations. Rather than testing these assumptions individually, the field applicability of the batch-test models was tested by comparing quantities predicted by the models with measurements of extractable ammonium in plume sediments. Variation in ionic concentrations was thereby evaluated by comparing the low-ionic-strength sorption models with the artificial-effluent model. These two models correspond to two sets of uniform conditions representing the end members of the continuous variation in the plume.
Concentrations of sorbed and dissolved ammonium based on the Langmuir sorption isotherms and dissolved concentrations in well water (predicted values) were compared with measured concentrations of $\mathrm{KCl}$ extractable ammonium in sediments (measured values). The comparison was made on a site-by-site basis to minimize variation associated with (1) scale differences and imprecise vertical control of sediment- and wellwater-sampling intervals and (2) small-scale lateral heterogeneity between the sediment-sampling site and the well locations. Seven sets of measurements from six sites in the plume, made in the spring and summer of 1992, were used.

The procedure for vertically integrating predicted and measured concentrations of sorbed plus dissolved ammonium at each site is illustrated in figure 26 . For the predicted concentrations, the Langmuir sorption isotherm ${ }^{2}$ was used to predict sorbed ammonium concentration from the dissolved concentration measured in ground water from two to six wells at each site. Each concentration of sorbed plus dissolved ammonium was then multiplied by a depth interval within which dissolved concentrations were assumed to be uniform. This depth interval was determined from the screened interval of the well (generally $5 \mathrm{ft}$ ) and the EM conductivity $\log$, as described previously for the mass-balance calculations. The concentration-depth products associated with all the wells at the site were summed to generate the predicted vertically integrated concentration value for the site. Measured values were obtained from $\mathrm{KCl}$ extractable-ammonium concentrations in aquifer sediment samples. The KCl-extractable-ammonium concentrations include sorbed and dissolved phases. Samples (2-inch sampling interval) were collected at about 3.5-foot intervals vertically through the plume. The $\mathrm{KCl}$-extractable concentrations were multiplied by a depth determined from the locations of the sample and adjacent samples. The concentration-depth products associated with all the sediment samples from the site were summed to generate the measured vertically

\footnotetext{
${ }^{2}$ For this calculation, the sorption isotherms were recalculated. Batch-test dissolved and sorbed ammonium concentrations, which were measured in $\mu \mathrm{g} / \mathrm{mL}$ as $\mathrm{N}$ (or $\mathrm{mg} / \mathrm{L}$ as $\mathrm{N}$ ) of ground water and $\mu \mathrm{g} / \mathrm{g}$ as $\mathrm{N}$ of dry sediment, respectively, were transformed into common units of microgram of nitrogen per cubic centimeter of aquifer $\left(\mu \mathrm{g} / \mathrm{cm}^{3}\right.$ as $\left.\mathrm{N}\right)$. A porosity value of 0.39 and bulk density value of $1.6 \mu \mathrm{g} / \mathrm{cm}^{3}$ were used.
} 
PREDICTED VALUES

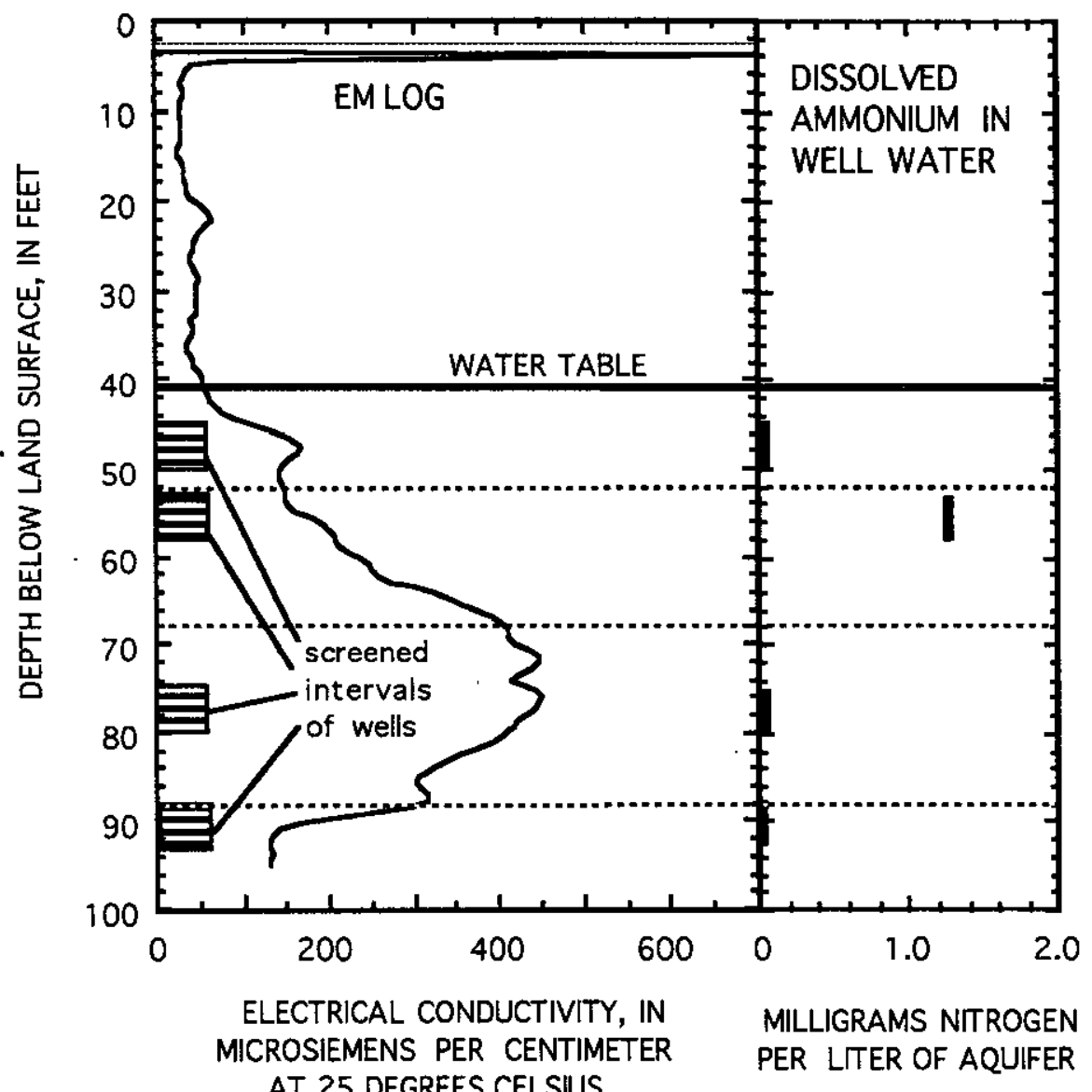

MEASURED VALUES

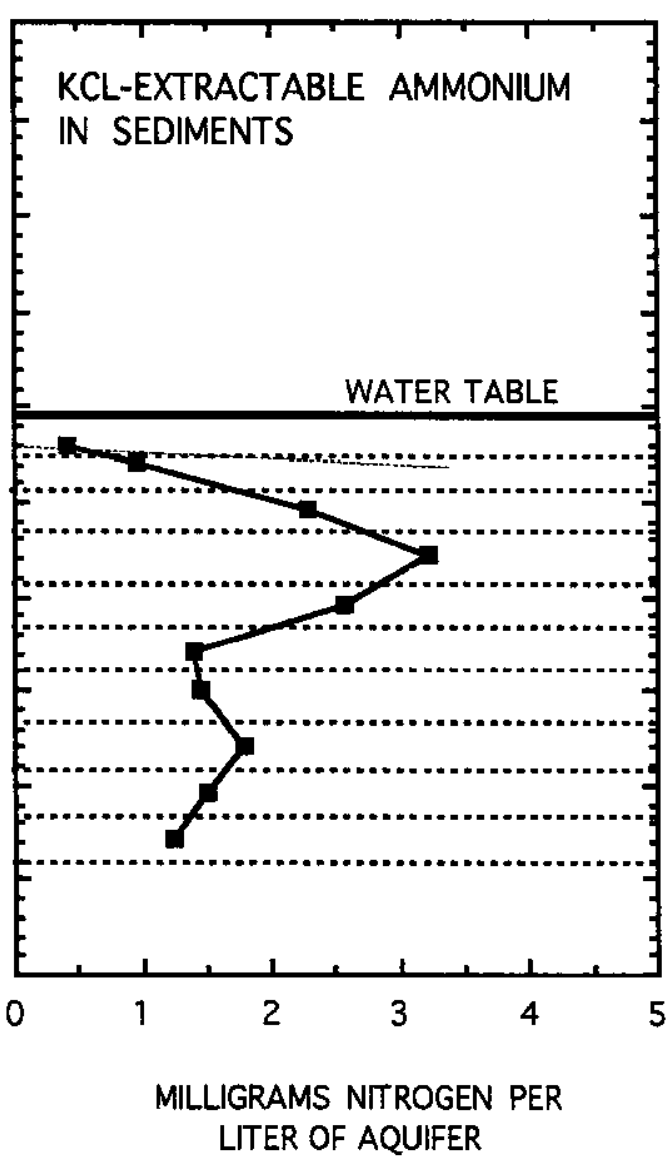

Figure 26. Illustration of vertical integration of predicted and measured sorbed-plus-dissolved ammonium concentration values, site 174 , September 1992. Predicted values calculated from dissolved concentrations in ground water from wells, vertically integrated using screened intervals of wells and EM (electromagneticinduction) log. Measured values calculated from $\mathrm{KCl}$ (potassium chloride) extractions of sediment samples, vertically integrated using sediment-sampling intervals. 
integrated concentration value for the site. Finally, predicted and measured vertically integrated concentration values were divided by the total thickness of the plume at the site, to eliminate any potential spurious correlation based on the common depth intervals.

The correlations between predicted and measured depth-weighted values are high $\left(R^{2} \geq 0.90\right)$ for lowionic-strength and artificial-effluent Langmuir sorption models (fig. 27). However, the slope of the straight-line relation for the low-ionic-strength estimates (slope $=4.36,95$-percent confidence interval $=2.79$ to 5.93 ) indicates that this model significantly overestimates ammonium sorption in the plume. In contrast, predicted concentrations based on the artificial-effluent Langmuir model are in good agreement with measured concentrations (slope $=1.25,95$-percent confidence interval $=0.92$ to 1.58 ). Ionic concentrations in the

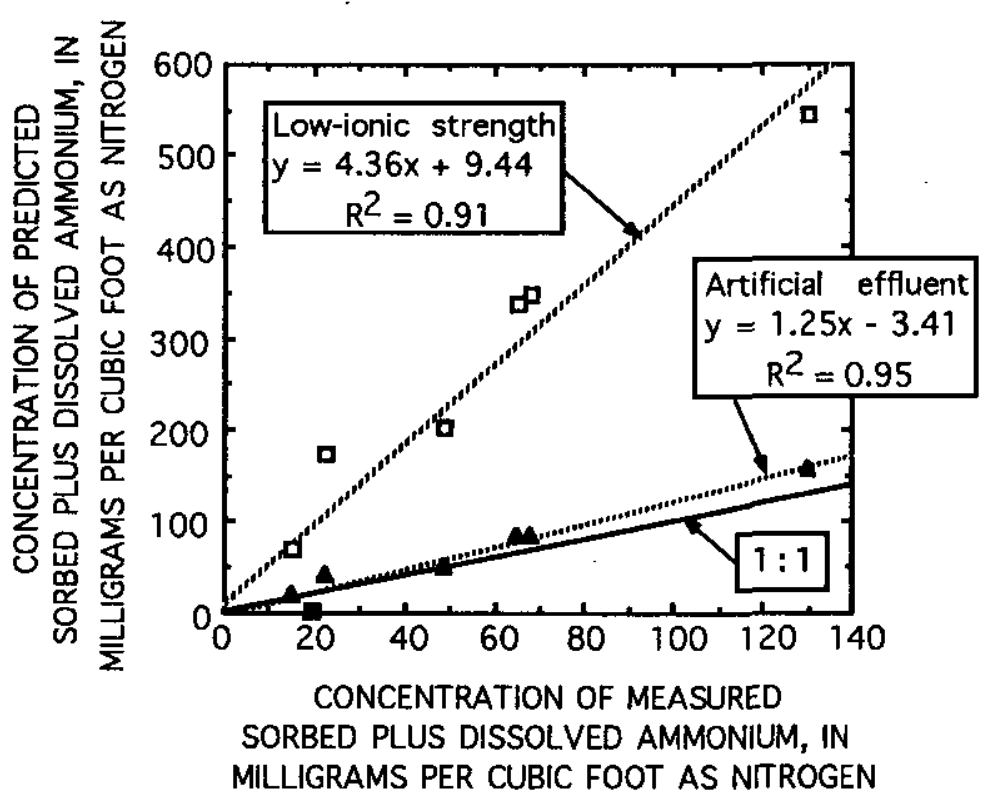

EXPLANATION

a LOW-IONIC-STRENGTH LANGMUIR SORPTION MODEL

• ARTIFICIAL-EFFLUENT LANGMUIR SORPTION MODEL

Figure 27. Relation between vertically integrated concentrations of sorbed plus dissolved ammonium based on batch-test sorption models (predicted) and on potassium-chloride extractions of sediments (measured). plume varied from the concentrations represented by the low-ionic-strength tests to those represented by the artificial-effluent test. However, ammonium concentrations were high only where ionic concentrations approached artificial-effluent concentrations. Therefore, the artificial-effluent Langmuir model better predicts sorbed-ammonium concentrations in the plume sediments.

\section{Mass Estimates of Sorbed Ammonium}

Masses of sorbed ammonium (in excess of background) in plume sediments were estimated for the five synoptic samplings as follows. First, sorbed concentrations were calculated from dissolved concentrations in ground water using the artificialeffluent Langmuir sorption model. The sorbed concentrations were then adjusted for background sorbed ammonium. Background sorbed concentration was calculated as the difference between total ( $\mathrm{KCl}$-extractable) ammonium in uncontaminated sediments (median $=0.12$ $\mu \mathrm{g} / \mathrm{cm}^{3}$ as $\mathrm{N}, \mathrm{n}=16$ ) and dissolved ammonium in ambient ground water (median $=0.02 \mathrm{mg} / \mathrm{L}$ as $\mathrm{N}$ or $0.008 \mu \mathrm{g} / \mathrm{cm}^{3}$ as $\mathrm{N}$ ). The sorbed concentrations were integrated using the triangular integration method, described previously, to generate mass estimates.

Sorbed ammonium in plume sediments was about three times the dissolved ammonium in the septage-effluent plume on a mass basis (table 10). Total nitrogen in the plume, calculated as the sum of masses of sorbed ammonium and masses of dissolved nitrogen species, accounted for 33 to 73 percent of the effluent-input nitrogen. These values corresponded to 68 to 103 percent of input masses, when normalized to the percentages of chloride recovered in the mass-balance analyses. Thus, ammonium sorption in saturated sediments was a significant sink for dissolved nitrogen in the septage-effluent plume. Moreover, the sorbedammonium masses were about equal to the apparent nitrogen losses in the June 1991 and June and December 1992 synoptic samplings. The good agreement between the total nitrogen and chloride percentages in the later synoptic samplings suggests that attenuation processes in the unsaturated and saturated zones other than 
Table 10. Sorbed and dissolved nitrogen masses in the septage-effluent plume, March, June, and September 1991, and June and December 1992

\begin{tabular}{|c|c|c|c|c|c|}
\hline \multirow{2}{*}{ Constituent } & \multicolumn{5}{|c|}{ Date of synoptic sampling } \\
\hline & Mar. 1991 & June 1991 & Sept. 1991 & June 1992 & Dec. 1992 \\
\hline \multicolumn{6}{|c|}{ Effluent-input masses, in kilograms } \\
\hline 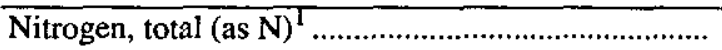 & 980 & 1,200 & 1,300 & 2,200 & 3,300 \\
\hline \multicolumn{6}{|c|}{ Masses in the septage-effluent plume, in kilograms } \\
\hline 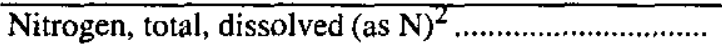 & 300 & 380 & 720 & 1,400 & 2,000 \\
\hline 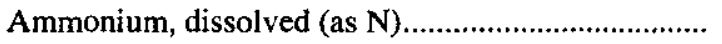 & 9.8 & 4.0 & 15 & 52 & 130 \\
\hline Nitrogen, total, dişsolved plus sorbed (as $\mathrm{N}$ ) .............. & 330 & 390 & 760 & 1,600 & 2,400 \\
\hline \multicolumn{6}{|c|}{ Masses in the septage-effluent plume, as a percentage of effluent-input masses } \\
\hline Nitrogen, total, dissolved plus sorbed (as $\mathrm{N}$ ) ............. & 34 & 33 & 58 & 73 & 73 \\
\hline 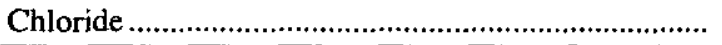 & 50 & 46 & 61 & 72 & 71 \\
\hline \multicolumn{6}{|c|}{ Masses in the septage-effluent plume, as a percentage of effluent-input masses, normalized to chloride masses } \\
\hline
\end{tabular}

ammonium sorption in the saturated zone (for example, filtration, assimilation and denitrification) were small and (or) transitory relative to the total nitrogen input.

Ammonium sorption in the unsaturated zone, a potential attenuation process, also was estimated independently as follows. First, sorbed concentrations were calculated from $\mathrm{KCl}$ extractions of unsaturated-zone sediments using the linear artificial-effluent model (table 9). The linear artificial-effluent model, which fit the batch-test data nearly as well as the Langmuir model, was used because it could be modified to generate sorbed concentrations from the $\mathrm{KCl}$-extraction data. Sorbed-ammonium concentrations in surface samples (median $=29 \mu \mathrm{g} / \mathrm{cm}^{3}$, interquartile range $=27 \mu \mathrm{g} / \mathrm{cm}^{3}$, $\mathrm{n}=27$; upper 0.16 -foot depth) and in subsurface sediments (median $=0.79 \mu \mathrm{g} / \mathrm{cm}^{3}$, interquartile range $=4.0$ $\mu \mathrm{g} / \mathrm{cm}^{3}, \mathrm{n}=63,0.16$ to 3.28 -foot depth) were integrated for the unsaturated-zone volume beneath the infiltration beds and extrapolated to the water table. The mass of sorbed ammonium in the unsaturated zone thus estimated is $9.5 \mathrm{~kg}$ as $\mathrm{N}$. This mass represents ammonium immobilized in the unsaturated zone after 26 months of effluent discharge. This mass is small relative to the masses of ammonium $(1,200 \mathrm{~kg}$ as $\mathrm{N})$ or total nitrogen $(2,000 \mathrm{~kg}$ as $\mathrm{N})$ discharged during that period. The mass of sorbed ammonium in the unsaturated zone also is small relative to the saturated-zone masses of sorbed ammonium (160 kg as $\mathrm{N}$ in June 1992) or total dissolved nitrogen $(1,400 \mathrm{~kg}$ as $\mathrm{N}$ in June 1992) in the plume. Thus, ammonium sorption in the unsaturated zone was not a large nitrogen sink.

\section{Denitrification}

Denitrification is the microbial reduction of nitrate and nitrite to nitrogen gases. Nitrate or nitrite serves as a terminal electron acceptor in the absence of oxygen, with organic carbon most frequently serving as the electron donor. It can be performed by a diverse group of facultative anaerobic bacteria (Ingraham, 1981; Knowles, 1982), which commonly occur in many environments (McNabb and Dunlap, 1975; Gamble and others, 1977; Tiedje and others, 1982). The reaction can be described by the equation,

$$
5 \mathrm{CH}_{2} \mathrm{O}+4 \mathrm{NO}_{3}^{-}+4 \mathrm{H}^{+} \rightarrow 2 \mathrm{~N}_{2}+5 \mathrm{CO}_{2}+7 \mathrm{H}_{2} \mathrm{O}
$$

where organic carbon is represented as a simplified carbohydrate, $\mathrm{CH}_{2} \mathrm{O}$ (Manahan, 1984, p. 102; Beauchamp and others, 1989, eq. 1). Denitrification rate may be controlled by concentrations of oxygen, nitrate, and organic carbon or other electron donor (Focht, 1982).

Denitrification in uncontaminated and nitrogenenriched ground water has been demonstrated by many recent studies (Hiscock and others, 1991; Korom, 
1992). Denitrification in ground water may be carbon or nitrate limited, depending on background concentrations. Denitrification rate was nitrate limited in aquifer sediments from the South Carolina coastal plain (Morris and others, 1988; Francis and others, 1989) and in shallow sandy glacial sediments from Long Island (Slater and Capone, 1987). Denitrification was carbon limited in a sewage-effluent-contaminated glacial aquifer on Cape Cod (Smith and Duff, 1988) and in sandy aquifers impacted by agricultural fertilizer (Starr and Giliham, 1993). The organic-carbon limitation is potentially complex because a wide variety of organic compounds are available to denitrifying organisms (Beauchamp and others, 1989). Additionally, only a fraction of the naturally occurring total organic carbon in soils or aquifer sediments generally is labile (Burford and Bremner, 1975; Reddy and others, 1982; Lalisse-Grundmann and others, 1988). Solid-phase organic carbon also may support denitrification (Trudell and others, 1986; Robertson and others, 1991).

Because of the natural variability of controlling factors, in situ denitrification is difficult to quantify (Tiedje and others, 1989). Several approaches were used to investigate the process in the present study. First, aquifer sediments were incubated as cores and slurries to estimate denitrification rates and to determine possible nitrate and carbon limitation. Second, measurements of dinitrogen, nitrous oxide, and inorganic carbon, which are produced by denitrification, were used to quantify in situ denitrification. Third, the nitrogen stable-isotope ratios of ammonium, nitrate, and dinitrogen in effluent and ground water were used to confirm the postulated nitrogen transformations and denitrification rates. Finally, the mass quantity of denitrification that occurred in the septage-effluent plume for the study period was estimated.

\section{Aquifer-Sediment Incubations}

\section{Denitrification Rates in Sediment Cores}

Denitrification rate in sediment cores from the anoxic zone of the plume ranged from 0 to 33 nanograms of nitrogen per cubic centimeter of aquifer per day $\left(\mathrm{ng}-\mathrm{N} / \mathrm{cm}^{3}\right) / \mathrm{d}$, with a mean of $9.6 \pm 7.4$ (ng-N/cm $\left.{ }^{3}\right) / \mathrm{d}$ ( \pm one standard deviation) and a positively skewed frequency distribution (fig. 28A). The rates in the suboxic mixing zone generally were less than 8 (ng$\mathrm{N} / \mathrm{cm}$ )/d (fig. 28B). In many cases, rates from vertically
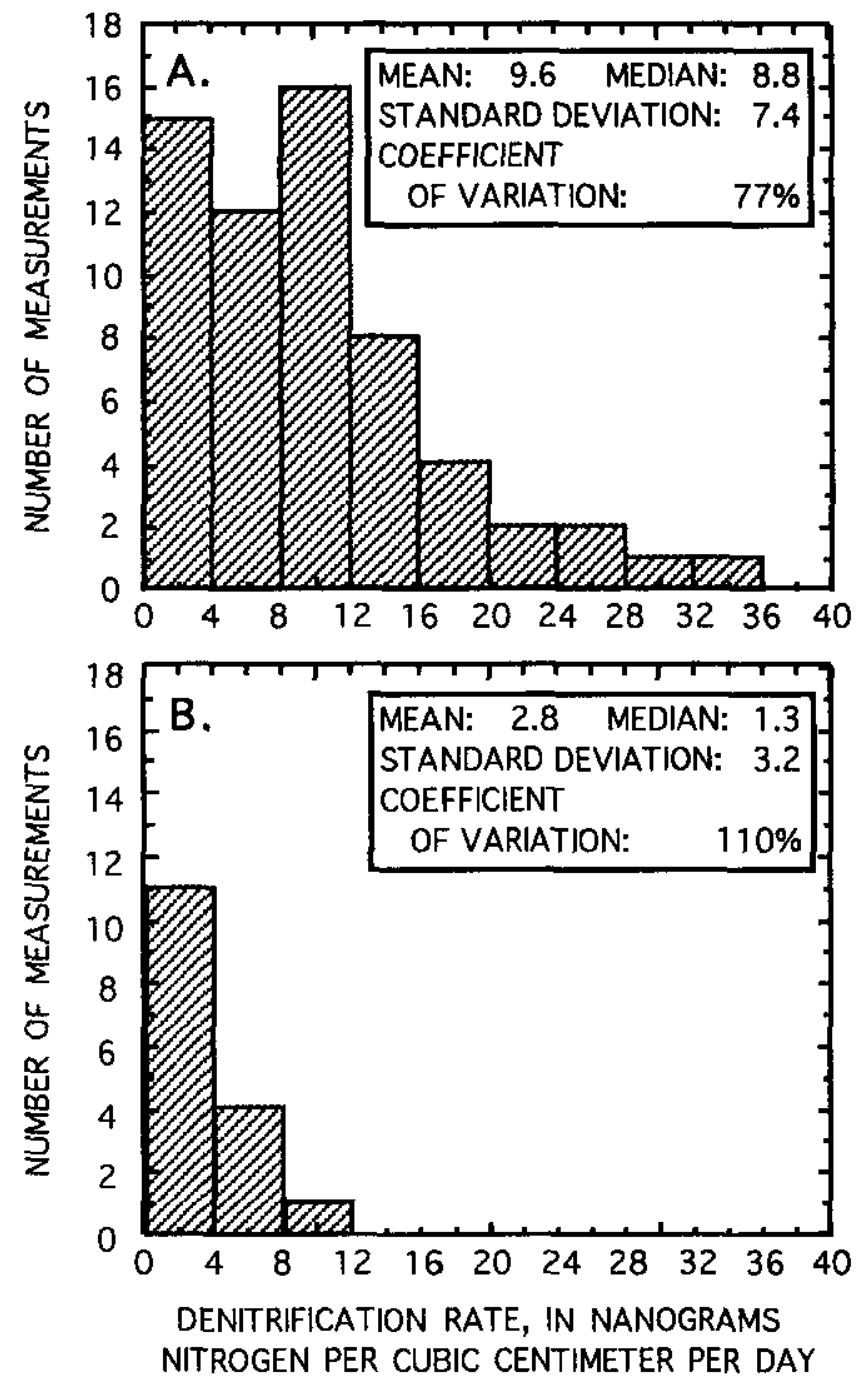

Figure 28. Frequency distributions of denitrification rates measured in sediment cores. $A$. Rates measured in sediment cores from the anoxic zone of the septage-effluent plume. B. Rates measured in sediment cores from the suboxic zone of the septage-effluent plume.

adjacent core segments (replicates) were highly variable (mean $\mathrm{CV}$ of replicates $=56$ percent, range $=<1$ to 170 percent). Such variability is common with measurements of denitrification rate in sediment cores (Kasper, 1982; Tiedje, 1982; Parkin, 1987).

Profiles of denitrification rate, EM conductivity, and concentrations in ground water at two sites from the anoxic zone (sites 106 and 96, fig. 10, August and September 1992) show that denitrification rates were high where oxygen was depleted and concentrations of nitrate and dissolved organic carbon were high (fig. 29A-B). 

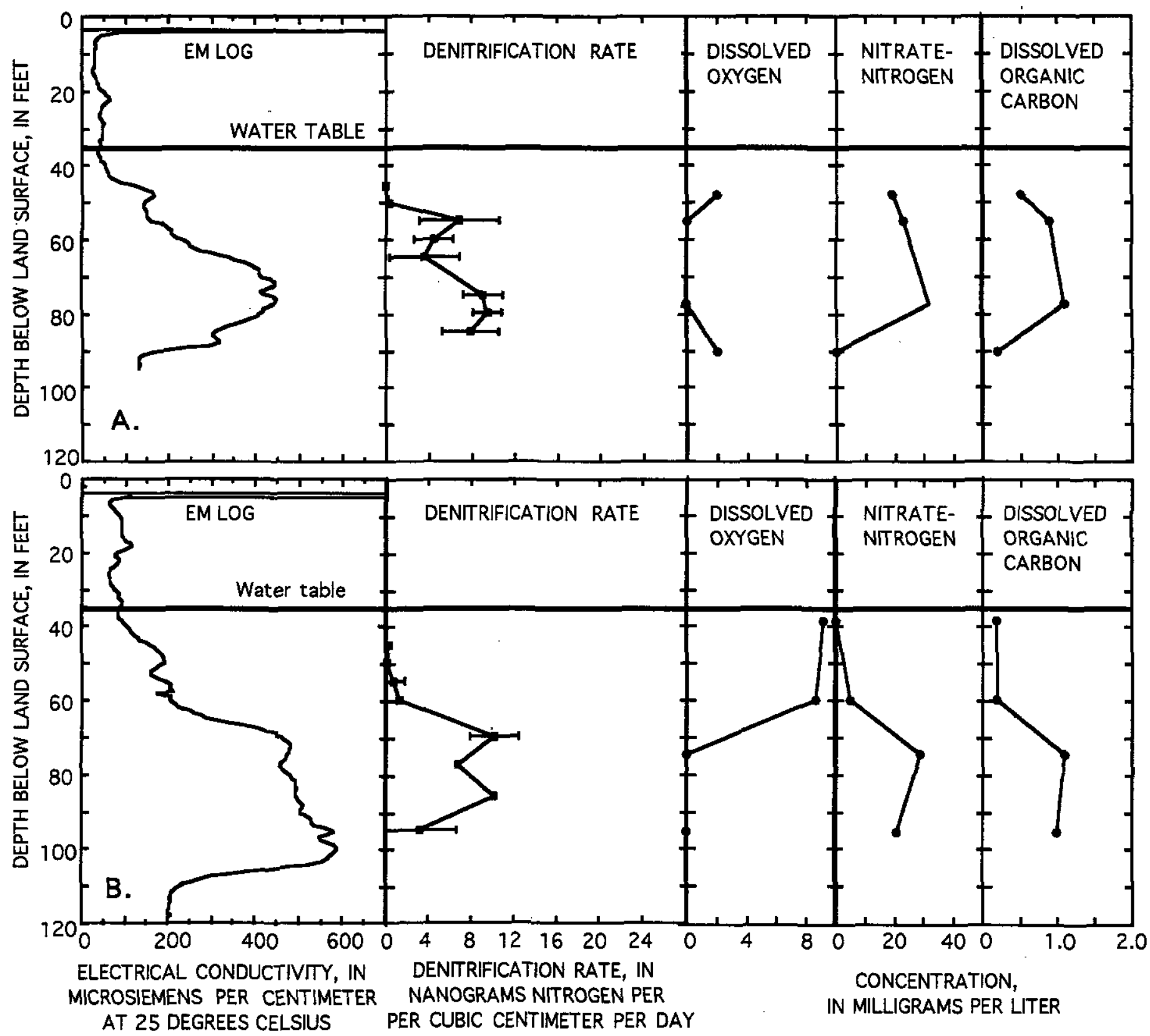

Figure 29. Electromagnetic-induction (EM) logs, denitrification rates measured in sediment cores, and concentrations of dissolved oxygen, nitrate, and dissolved organic carbon at two sites in the septageeffluent plume. Error bars on denitrification rate are \pm one standard deviation of two to three replicates (vertically adjacent core segments). A. Site 174, September 1992. B. Site 96, August 1992.

Repeated measurements (July and December 1991, and April and September 1992) at site 147, the site with the highest denitrifying activity, showed no temporal trend. Moreover, the variation of combined measurements from all sampling dates within 10 -foot depth intervals
( $\mathrm{CV}=62$ to 89 percent) was not much greater than the variation of replicate measurements on each sampling date (mean CV per sampling date $=37$ to 69 percent; fig. 30). The measured variation between adjacent core segments collected from a zone of apparently uniform 


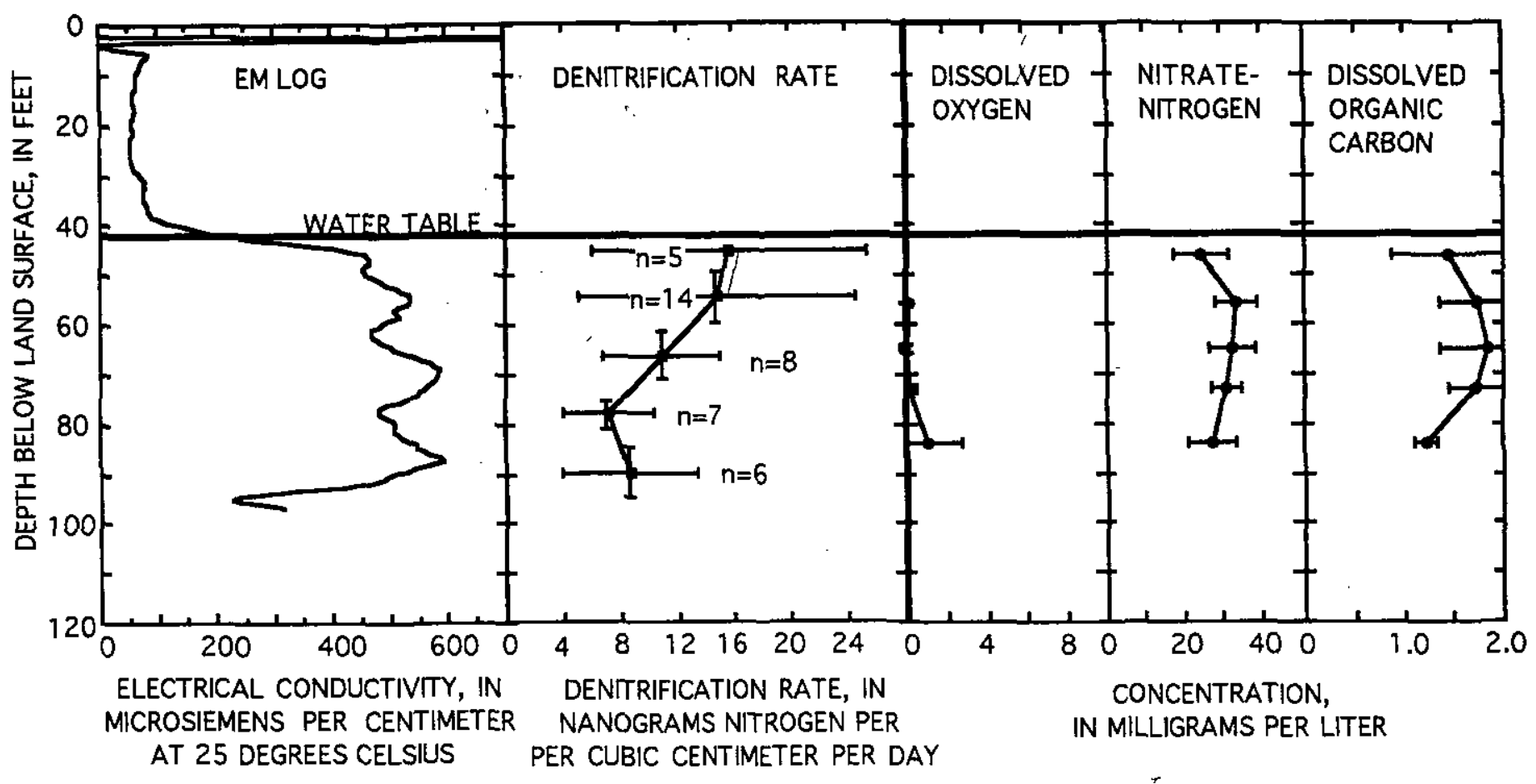

Figure 30. Electromagnetic-induction (EM) log (April 1992), denitrification rates measured in sediment cores, and concentrations of dissolved oxygen, nitrate, and dissolved organic carbon at site 147. July and December 1991 and April and September 1992. Horizontal bars on denitrification rate are \pm one standard deviation of multiple measurements $(n=5$ to 14$)$; vertical bars are depth ranges within which measurements were made. Error bars on concentrations are \pm one standard deviation $(n=4)$.

concentrations of dissolved oxygen, nitrate, and dissolved organic carbon may have resulted from perturbations during coring. Small-scale variation in pore-water concentrations not detected by concentrations measured in ground water from wells also may have been a factor (Ronen and others, 1987b; Pederson and others, 1991).

\section{Denitrification Rates in Sediment Slurries and Rates With Nitrate and Carbon Addition}

Nitrous oxide production in unamended slurry incubations generally was linear with time $\left(R^{2}=0.89\right.$ to 0.99 ), although frequently there was a 1-day time lag similar to that found by Smith and Duff (1988). Denitrification rates in unamended slurries ranged from 27 to $440\left(\mathrm{ng}-\mathrm{N} / \mathrm{cm}^{3}\right) / \mathrm{d}$, with a mean of $150 \pm 130(\mathrm{ng}-$ $\left.\mathrm{N} / \mathrm{cm}^{3}\right) / \mathrm{d}(\mathrm{n}=16, \pm$ one standard deviation). The slurry rates were more than tenfold higher than rates measured in sediment cores. The difference between slurry and core rates is similar to that reported by Smith and others (1987) in a sewage plume on Cape Cod and by Myrold and Tiedje (1985) for forest and agricultural soils. Slurry rates were not related to initial nitrate concentrations ( $p=0.1324$, Kendall's Tau correlation; 1.6 to 36 $\mathrm{mg} / \mathrm{L}$ as $\mathrm{N}$ ) or dissolved organic carbon $(p=0.4559$, Kendall's Tau correlation; 0.3 to $1.9 \mathrm{mg} / \mathrm{L}$ ) in the slurry water. The nitrate concentration in slurry water would not be expected to correlate with rate, because even the lowest concentration was likely greater than rate-limiting concentrations (Knowles, 1982; Murray and others, 1989). The high rates and lack of correlation with concentrations of dissolved organic carbon in the slurry water may have resulted from enhanced microbial activity from physical mixing. Physical mixing and abrasion may increase the availability of solid-phase organic carbon (Myrold and Tiedje, 1985) and also can reduce diffusion zones present within intact cores. The uniformly anoxic conditions in the slurries, as compared with the more variable oxygen concentrations in the core incubations, also may have contributed to the difference between slurry and core rates. 
Sediments from the most centrally located site in the anoxic zone (site 147, December 1991) were amended with nitrate and a readily degradable carbon source, glucose, to test for nitrate and carbon limitation of denitrification rate (fig. 31). Concentrations in the unamended replicates were $36 \mathrm{mg} / \mathrm{L}$ as $\mathrm{N}$ of nitrate and $1.9 \mathrm{mg} / \mathrm{L}$ of dissolved organic carbon. Nitrous oxide production in the replicates amended with glucose and glucose plus nitrate was stimulated. The denitrification rate increased with time and was about four times the unamended rate after 5.6 days (fig. 31 ). In contrast, the addition of nitrate had no effect on denitrification rate. Nitrous oxide production in the nitrate-amended replicates was similar to the low, linear rates in most of the unamended slurries. These data suggest that the denitrification rate in the septage-effluent plume primarily was carbon limited.

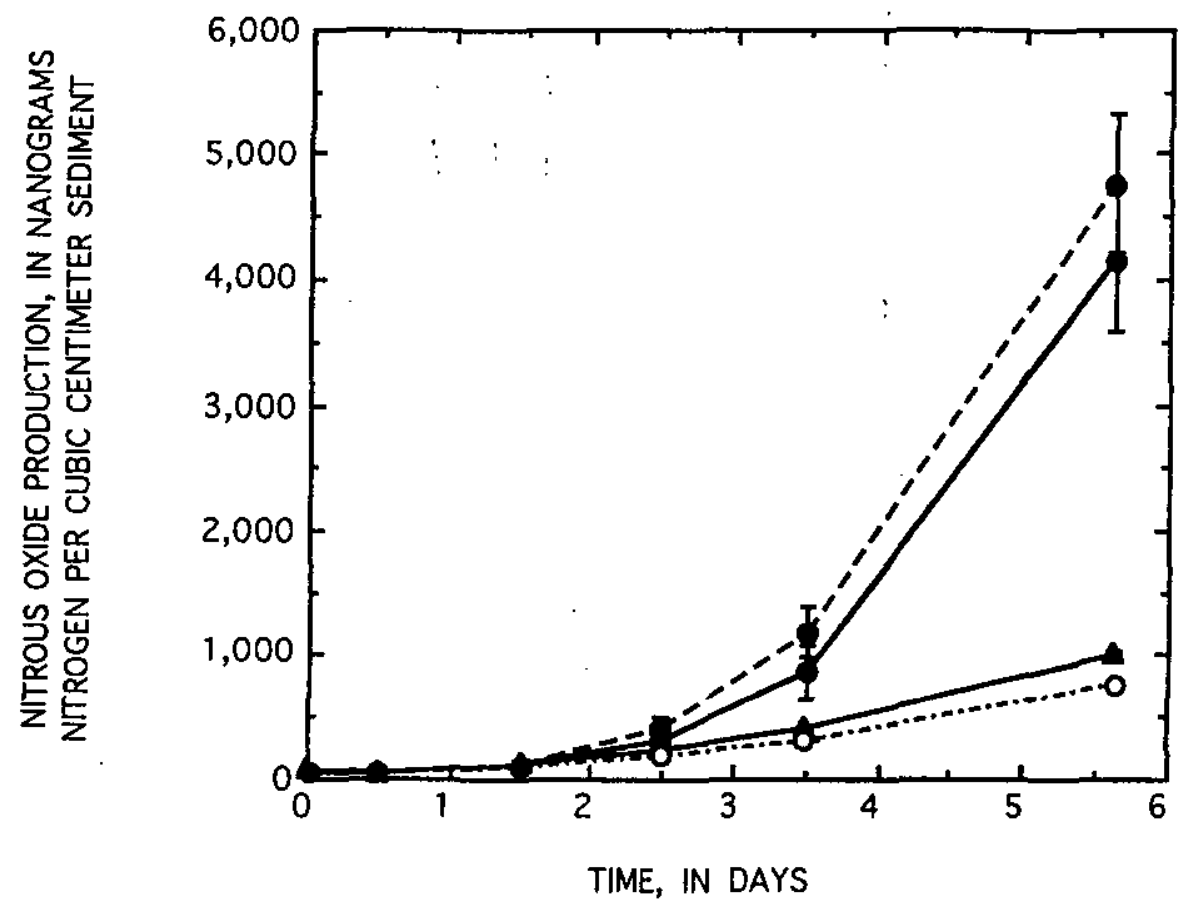

EXPLANATION

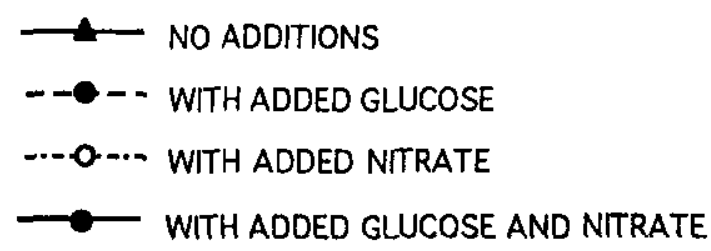

Figure 31. Nitrous oxide production in sediment slurries with nitrate and carbon addition. Error bars are \pm one standard deviation of three replicates. Sediment from site 147, 65 feet below land surface, December 1991. 


\section{Dinitrogen, Nitrous Oxide, and Dissolved Inorganic Carbon}

\section{Dinitrogen}

Dinitrogen is the stable end product of denitrification, and can accumulate in ground water (Vogel and others, 1981; Wilson and others, 1990; Fontes and others, 1991; Smith and others, 1991). Dinitrogen concentrations in the plume ranged from $17.7 \pm 0.5$ to $21.2 \pm 0.5 \mathrm{mg} / \mathrm{L}$ as $\mathrm{N}$ ( \pm one standard deviation of two to three replicates; fig. 32 ). Concentrations in the center of the plume were 1 to $2 \mathrm{mg} / \mathrm{L}$ as $\mathrm{N}$ higher than the mean concentration in ambient ground water from similar depths, $18.6 \mathrm{mg} / \mathrm{L}$ as $\mathrm{N}(\mathrm{n}=10$, standard deviation=1.2) or than the concentration predicted from atmospheric equilibrium, $18.3 \mathrm{mg} / \mathrm{L}$ as $\mathrm{N}$ (at $10^{\circ} \mathrm{C}$ and 1 atmosphere, Matthess, 1982). Dinitrogen concentrations at individual sites also increased with time due to transport associated with the anoxic volume of the plume. For example, concentrations in ground water from OSW 98 and OSW 114 (site 96) increased from $18 \pm 0.6$ and $18.8 \pm 1.2 \mathrm{mg} / \mathrm{L}$ as $\mathrm{N}$ to $20.6 \pm 0.2$ and $20.2 \pm 0.05 \mathrm{mg} / \mathrm{L}$ as $\mathrm{N}$, respectively, from March 1991 to December 1992 (fig. 33). In contrast, dinitrogen concentrations in ambient ground water from a deep well at site 96 (OSW 96, screened below the plume) did not significantly change with time, although the concentration was initially higher than concentrations in the shallower wells (fig. 33). In addition, the dinitrogen increases coincided with the beginning of rapid dissolved-oxygen decreases at the wells in mid-1991 (figs. $14 B$ and $C$ ), as would be expected if the dinitrogen originated from denitrification.

Rates of denitrification integrated over the flow paths from the infiltration beds to 10 wells at sites 93 , $96,147,149$, and 174 in the anoxic zone were calculated from the dinitrogen concentrations and saturatedzone residence times of ground water intercepted by the wells. Dinitrogen exceeding the mean ambient concentration, $18.6 \mathrm{mg} / \mathrm{L}$ as $\mathrm{N}$, was attributed to denitrification. Residence times were calculated from three-dimensional flow-path distances from the water table beneath the infiltration beds to the wells, determined from hydraulic-head gradients, and the mean ground-water velocity, $0.5 \mathrm{ft} / \mathrm{d}$; porosity was assumed equal to 0.39 . The denitrification rates thus calculated ranged from 1.4 to $6.2\left(\mathrm{ng}-\mathrm{N} / \mathrm{cm}^{3}\right) / \mathrm{d}$, with a mean rate of $3.0 \pm 1.4$

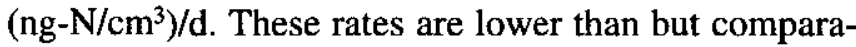
ble to the sediment-core rates.

\section{Nitrous Oxide}

Nitrous oxide is an intermediate in denitrification and may accumulate under low-pH, high-nitrate conditions (Blackmer and Bremner, 1978; Firestone and others, 1980). Although lower on a mass basis than dinitrogen concentrations, nitrous oxide concentrations in the plume were much higher than natural background concentrations. Nitrous oxide concentrations in ambient ground water generally were less than $5 \mu \mathrm{g} / \mathrm{L}$ as $\mathrm{N}$. Concentrations in the plume ranged from 46 to 660 $\mu \mathrm{g} / \mathrm{L}$ as $\mathrm{N}$. The highest concentrations were measured at sites adjacent to the infiltration beds (site 93 and 147). However, nitrous oxide was also found in oxygenated zones of the plume near its leading and lateral edges. In fact, nitrous oxide concentrations in some cases were higher than background concentrations before high concentrations of any other effluent tracer, such as chloride or EM conductivity, were apparent. Moreover, with the exception of several outliers, nitrous oxide concentration was linearly related to chloride concentration (fig. 34A). The linear relation suggests that dilution may have been the primary process controlling nitrous oxide distribution in the saturated zone.

The distribution of nitrous oxide and the linear relation with chloride suggest that much of the nitrous oxide in the plume may have been produced during nitrification in the unsaturated zone. Nitrous oxide has been reported to account for 0.02 to 2.6 percent of the ammonium-nitrogen oxidized in nitrification (Yoshida and Alexander, 1970; Blackmer and others, 1980; Davidson and others, 1986; Tortuoso and Hutchinson, 1990; Ueda and others, 1993). Because about $20 \mathrm{mg} / \mathrm{L}$ as $\mathrm{N}$ of ammonium in effluent was nitrified in the unsaturated zone (table 5), 0.004 to $0.52 \mathrm{mg} / \mathrm{L}$ as $\mathrm{N}$ of nitrous oxide (4 to $520 \mu \mathrm{g} / \mathrm{L}$ as $\mathrm{N}$ ) may have been produced. At five wells near the infiltration beds (sites 93 and 147), nitrous oxide was about twice as high as concentrations in downgradient wells with similar 


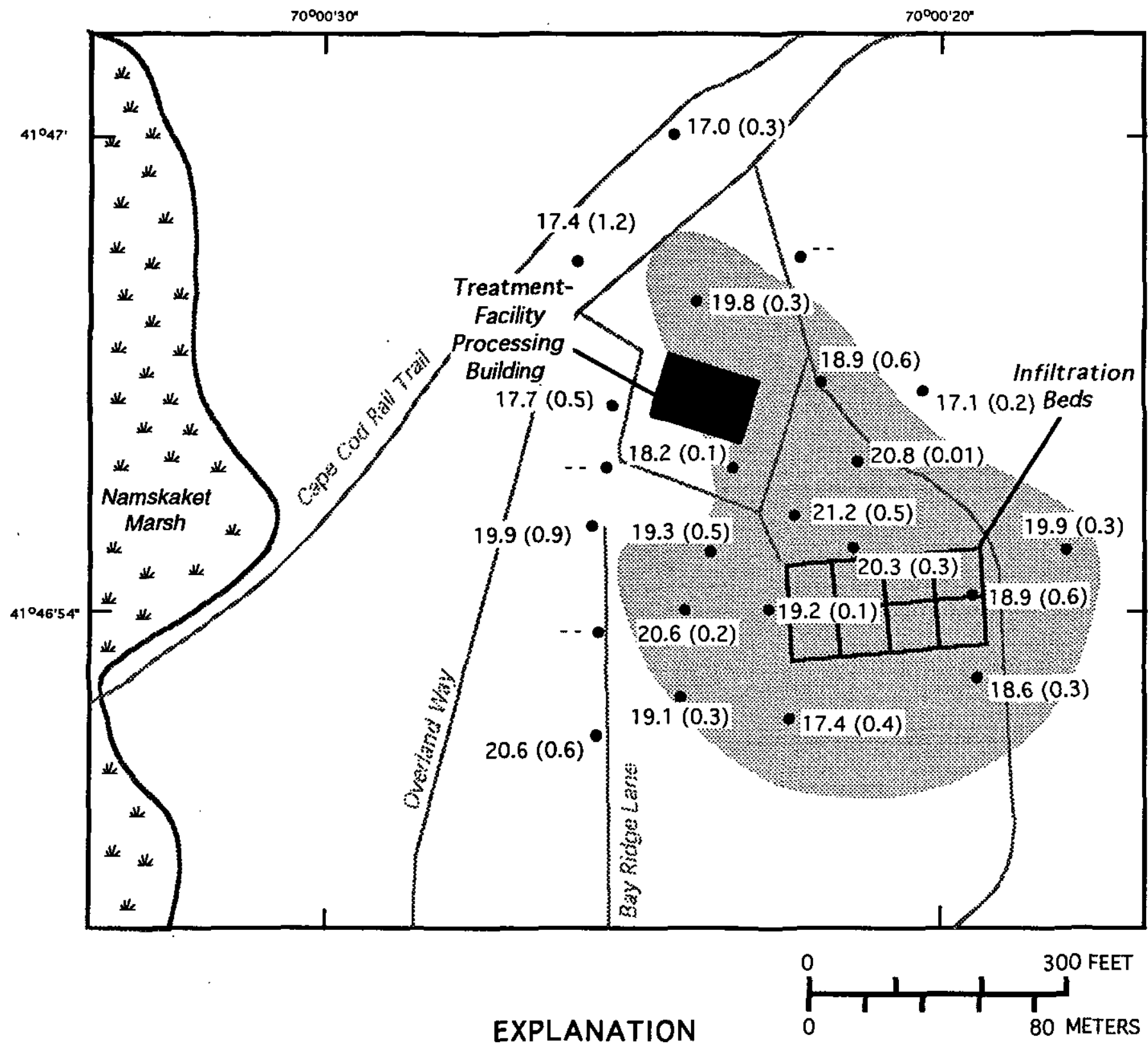

\section{AREA OF CHLORIDE CONCENTRATIONS EQUAL TO OR GREATER THAN 200 MILLIGRAMS PER LITER \\ - WELL CLUSTER SITE--Site of one or more observation wells completed at different depths. \\ $18.6(0.4) \quad$ Number is maximum concentration of dinitrogen, in milligrams per liter as nitrogen. \\ Number in parentheses is standard deviation of two to three replicates. --, no data}

Figure 32. Areal distribution of dinitrogen in the septage-effluent plume, December 1992. 


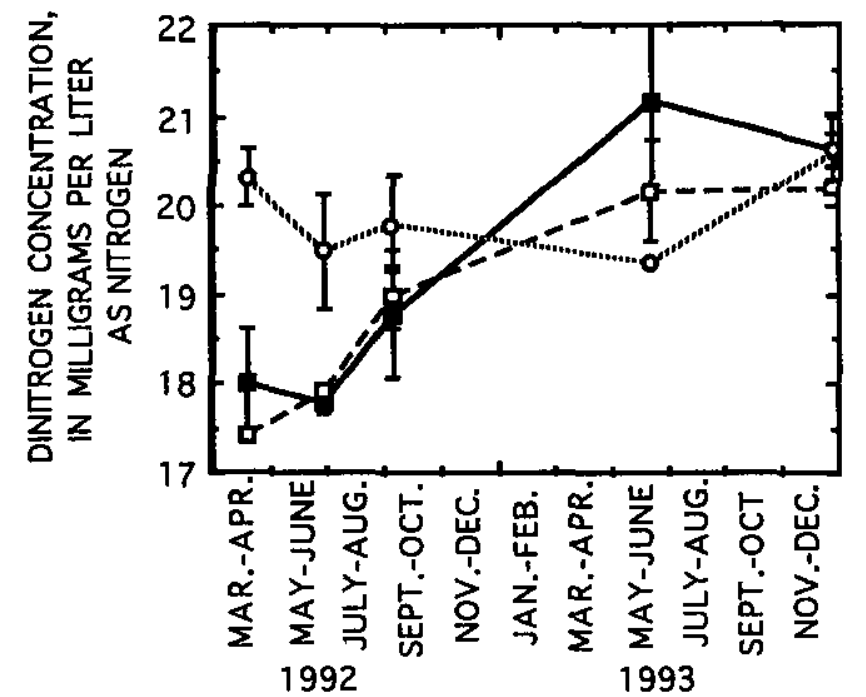

EXPLANATION

$-\rightarrow-$ OSW 114

$\longrightarrow$ OSW 98

................ OSW 96

Figure 33. Concentrations of dinitrogen in ground water in three wells at site 96, March 1991 through December 1992. Error bars are \pm one standard deviation of two to three replicates. OSW 114 and OSW 98 are screened in the anoxic zone of the plume; OSW 96 is screened below the septageeffluent plume.

chloride concentrations (fig. 34A). These exceptionally high concentrations may have resulted from the increased discharge during the preceding summer months (fig. 6), which may have reduced outgassing in the unsaturated zone through higher moisture contents.

\section{Dissolved Inorganic Carbon}

Dissolved inorganic carbon is produced from organic carbon primarily by denitrification and aerobic respiration. Concentrations of dissolved inorganic carbon in the center of the plume, 21 to $26 \mathrm{mg} / \mathrm{L}$ in December 1992, were two to three times greater than concentrations in ambient ground water (median=9.4 mg/L, $\mathrm{n}=23$ ). Concentrations of dissolved inorganic carbon also were linearly related to chloride concentrations (fig. 34B). The high concentrations of dissolved inorganic carbon were not produced by denitrification. Aerobic respiration in the unsaturated zone produced about 10 to $20 \mathrm{mg} / \mathrm{L}$ of inorganic carbon
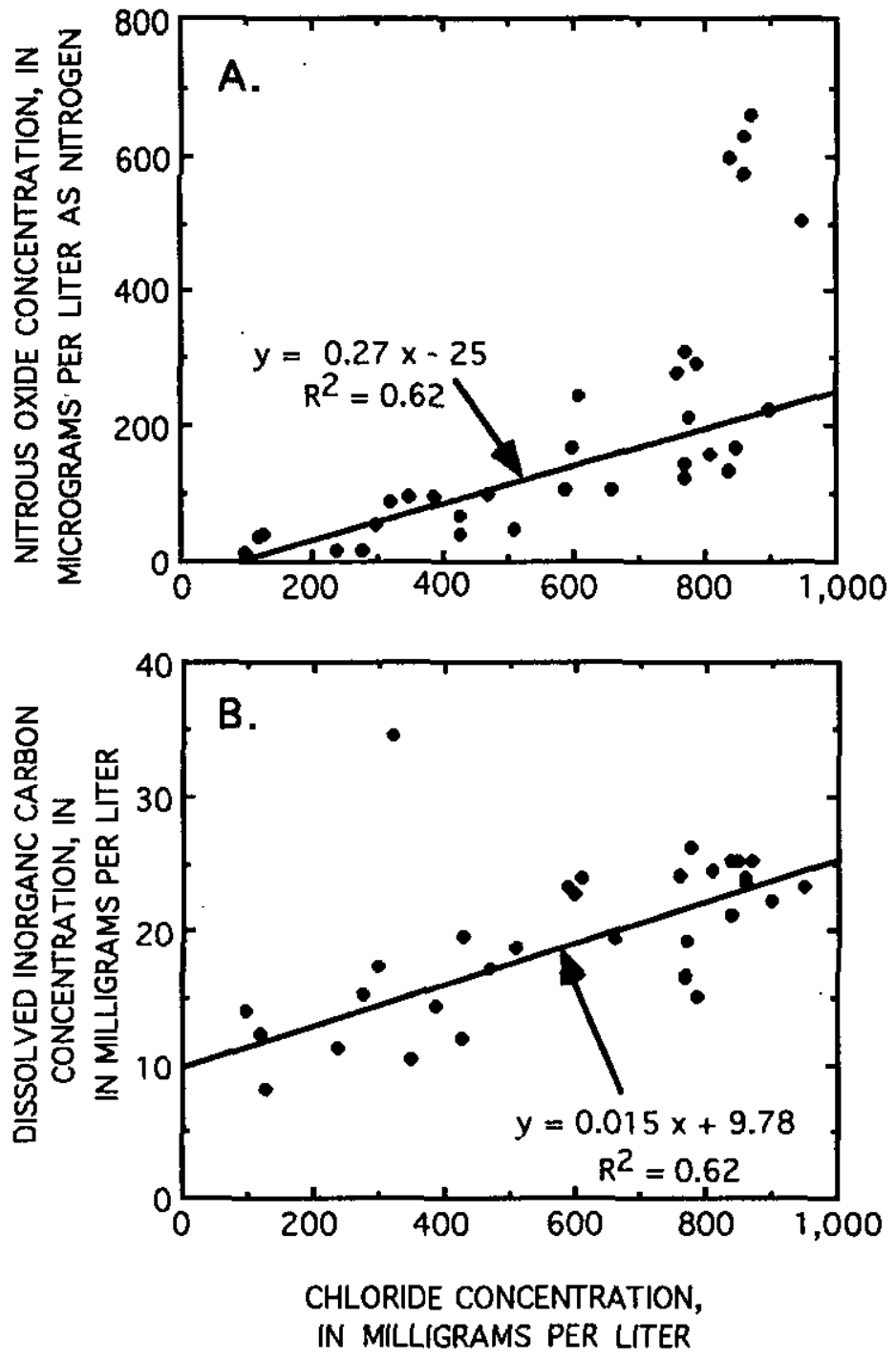

Figure 34. Relations of nitrous oxide and dissolved inorganic carbon concentrations with chloride concentrations in the septage-effluent plume, December 1992. A. Nitrous oxide with chloride. (Regression line excludes points with nitrous oxide concentration greater than 400 micrograms per liter as nitrogen.) B. Dissolved inorganic carbon with chloride. (Regression line excludes point with dissolved inorganic carbon concentration greater than 30 milligrams per liter.)

(table 5). Dissolved inorganic carbon also was present in the effluent when discharged (about $13 \mathrm{mg} / \mathrm{L}$, assuming all the alkalinity was due to dissolved carbon dioxide species; table 4) due to the biological-treatment process. Denitrification contributed about 2 to $3 \mathrm{mg} / \mathrm{L}$ of dissolved inorganic carbon, based on the stoichiometric relation between nitrate and carbon (eq. 12) and dinitrogen concentrations in excess of background or 
equilibrium concentrations. Thus, the contribution of denitrification was relatively small and was not apparent in the concentrations of dissolved inorganic carbon measured in December 1992.

Large concentrations of dissolved inorganic carbon ( 31 to $44 \mathrm{mg} / \mathrm{L}$ ) were measured in five shallow wells located in grassy areas around the main building and between Overland Way and the Cape Cod Rail Trail (fig. 2). Only one of these wells is screened within the boundaries of the plume. The concentration in this well is represented by the single outlier in the correlation between dissolved inorganic carbon and chloride (fig. 34B). Concentrations of dissolved inorganic carbon in ground water from these wells were consistently high for all synoptic samplings and may be related to above-ground landscaping practices.

\section{Nitrogen Stable-Isotope Ratios}

Alterations in the stable-isotope ratios of nitrate and dinitrogen are potential indicators of denitrification, due to the preferential reduction of ${ }^{14} \mathrm{~N}$-nitrate by denitrifying bacteria (Delwiche and Steyn, 1970). This fractionation results in ${ }^{15} \mathrm{~N}$ enrichment of the remaining nitrate pool and ${ }^{14} \mathrm{~N}$ enrichment of the dinitrogen that is produced. Nitrification can have a similar effect, enriching ammonium pools in ${ }^{15} \mathrm{~N}$, while depleting ${ }^{15} \mathrm{~N}$ in the remaining nitrate pool.

Stable-isotope ratios of total dissolved nitrogen (all species except dinitrogen) and individual nitrogen species in effluent were measured in two samples that represented the range of variability in nitrogen-species distribution at discharge (table 11). The fractionation effect of nitrification was apparent in the nitrate-rich sample. The residual unoxided ammonium $\left(\delta^{15} \mathrm{~N}=\right.$ $+25.4 \%$ ) was enriched in ${ }^{15} \mathrm{~N}$ relative to the nitrate $\left(\delta^{15} \mathrm{~N}=+9.8 \%\right.$. The residual ammonium in the nitraterich sample also was ${ }^{15} \mathrm{~N}$ enriched relative to the ammonium in the ammonium-rich effluent sample, in which little nitrification had taken place. However, because nitrification had proceeded nearly to completion, the ${ }^{15} \mathrm{~N}$ of the nitrate was only slightly ${ }^{15} \mathrm{~N}$ depleted relative to the total dissolved nitrogen $\left(\delta^{15} \mathrm{~N}=+11.2 \%\right.$ ). Ammonium in effluent underwent nearly complete nitrification in the unsaturated zone throughout the study, and nitrate represented about 90 percent of the total dissolved nitrogen reaching the water table. Therefore, the $\delta^{15} \mathrm{~N}$ ratios of nitrate recharged to the aquifer was about equal to the $\delta^{15} \mathrm{~N}$ of total dissolved nitrogen in effluent. The $\delta^{15} \mathrm{~N}$ ratios of total dissolved nitrogen in the two effluent samples were dissimilar $(+11.2$ and $+19.1 \%$ ), although within the range of +10 to $+22 \%$ commonly cited for nitrogen in human waste (Kreitler, 1979; Heaton, 1986; Mariotti and others, 1988; Aravana and others, 1993).

As in the nitrate-rich effluent sample, $\delta^{15} \mathrm{~N}$ ratios of ammonium in ground water were enriched in ${ }^{15} \mathrm{~N}$ relative to the $\delta^{15} \mathrm{~N}$ ratios of nitrate or total dissolved nitrogen, which were similar (table 11). Nitrate in ground water from the anoxic zone $\left(\delta^{15} \mathrm{~N}=+7.3 \pm 1.5 \%\right)$ or the suboxic zone $\left(\delta^{15} \mathrm{~N}=+8.2 \%\right.$ ) does not appear enriched in ${ }^{15} \mathrm{~N}$ from denitrification, relative to $\delta^{15} \mathrm{~N}$ ratios of effluent (table 11). Similarly, preferential uptake and denitrification of ${ }^{14} \mathrm{~N}-\mathrm{NO}_{3}^{-}$is not evident in the $\delta^{15} \mathrm{~N}-\mathrm{N}_{2}$ ratios in the plume. $\delta^{15} \mathrm{~N}-\mathrm{N}_{2}$ ratios in the anoxic zone $(+1.0 \pm 0.3 \%)$ and the suboxic zone $(+1.0 \%)$ were similar to the $\delta^{15} \mathrm{~N}$ ratios of dissolved $\mathrm{N}_{2}$ in equilibrium with the atmosphere $(+0.8-0.9 \%$, Letolle, 1980) and to the $\delta^{15} \mathrm{~N}-\mathrm{N}_{2}$ of ambient ground water $(+0.8 \%)$.

The fractionation that would result from the denitrification of $2.6 \mathrm{mg} / \mathrm{L}$ as $\mathrm{N}$ (the maximum quantity indicated by dinitrogen data) was estimated to determine whether the measured $\delta^{15} \mathrm{~N}$ ratios were consistent with the denitrification estimates from the other methods. Fractionation effects can be calculated by inferring a single-step, irreversible Rayleigh process (Vogel and others, 1981; Mariotti and others, 1981, 1988; Smith and others, 1991),

$$
\delta^{15}{\mathrm{~N}-\mathrm{NO}_{3}}^{-}=\delta^{15}{\mathrm{~N}-\mathrm{NO}_{3}{ }_{\text {(initial) }}^{-}}^{-}(\varepsilon \cdot \ln f),
$$

and

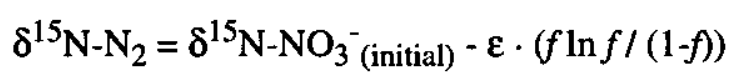

where

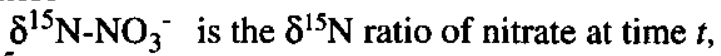
$\delta^{15} \mathrm{~N}-\mathrm{NO}_{3}{ }^{-}$(initial) ${ }^{\text {is the initial }} \delta^{15} \mathrm{~N}$ ratio in nitrate,

$\varepsilon$ is the isotopic enrichment factor,

$f$ is the ratio of nitrate-nitrogen concentration at time $t$ to initial nitrate-nitrogen concentration, and

$\delta^{15} \mathrm{~N}-\mathrm{N}_{2}$ is the $\delta^{15} \mathrm{~N}$ ratio in dinitrogen from denitrification (Mariotti and others, 1981, eqs. 8 and 12).

Values of $\varepsilon$ equal to $-10 \%$ (Mariotti and others, 1988; Böttcher and others, 1990; Smith and others,

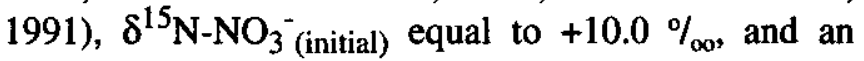
initial nitrate concentration of $35 \mathrm{mg} / \mathrm{L}$ as $\mathrm{N}$ were 
Table 11. Stable-isotope ratios and concentrations of nitrogen species in effluent and ground water, July 1992

[Concentrations in milligrams per liter, dissolved as $\mathrm{N}$; stable-isotope ratios in per mil. Nitrate-rich effluent sample collected in January 1993. Total nitrogen includes nitrate-, nitrite-, and ammonium-nitrogen, and dissolved organic nitrogen. Dinitrogen concentrations are means and standard deviations of two to three replicates. Concentrations from the center of the plume are means of samples from sites 93 , $96,147,149,169 ;$ standard deviations are from these five samples. Concentrations from the leading edge of the plume are from one sample, site 156. Background concentrations are from one sample, site 105 (OSW 104, screened above the plume). <, actual value is less than value shown. --, no data]

\begin{tabular}{|c|c|c|c|c|c|c|c|c|c|c|}
\hline \multirow[b]{2}{*}{ Sample type } & \multicolumn{2}{|c|}{ Nitrate } & \multicolumn{2}{|c|}{ Ammonium } & \multicolumn{2}{|c|}{ Nitrogen, organic } & \multicolumn{2}{|c|}{ Nitrogen, total } & \multicolumn{2}{|c|}{ Dinitrogen. } \\
\hline & $\begin{array}{c}\text { Concen- } \\
\text { tration }\end{array}$ & $\begin{array}{c}\text { Stable- } \\
\text { isotope } \\
\text { ratio }\end{array}$ & $\begin{array}{c}\text { Concen- } \\
\text { tration }\end{array}$ & $\begin{array}{c}\text { Stable- } \\
\text { isotope } \\
\text { ratio }\end{array}$ & $\begin{array}{l}\text { Concen- } \\
\text { tration }\end{array}$ & $\begin{array}{c}\text { Stable- } \\
\text { isotope } \\
\text { ratio }\end{array}$ & $\begin{array}{c}\text { Concen- } \\
\text { tration }\end{array}$ & $\begin{array}{c}\text { Stable- } \\
\text { isotope } \\
\text { ratio }\end{array}$ & $\begin{array}{c}\text { Concen- } \\
\text { tration : }\end{array}$ & $\begin{array}{c}\text { Stable- } \\
\text { isotope } \\
\text { ratio }\end{array}$ \\
\hline \multicolumn{11}{|c|}{ Effluent } \\
\hline Ammonium-rich sample............. & 0.9 & - & 37 & +17.8 & 12 & -- & 50 & +19.1 & 14.8 & +1.9 \\
\hline Standard deviation ...................... & . :- & -- & -- & -- & -- & -- & -- & -- & .2 & - \\
\hline Nitrate-rich sample & $1_{21}$ & +9.8 & $1_{3.4}$ & +25.4 & -- & -- & $\mathrm{I}_{22}$ & +11.2 & 18.2 & +.1 \\
\hline 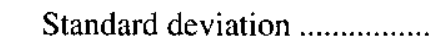 & . $\quad--$ & -- & -- & -- & -- & -- & -- & -- & .7 & -- \\
\hline \multicolumn{11}{|c|}{ Ground Water } \\
\hline 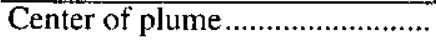 & 27 & +7.3 & 2.5 & +19.4 & 1.1 & -- & 30 & +7.8 & 20.9 & +1.0 \\
\hline Standard deviation ...................... & 4.6 & 1.5 & 1.5 & 3.0 & .8 & -- & 5.7 & 1.4 & .5 & .3 \\
\hline Leading edge of plume................... & .02 & +8.2 & 9.6 & -- & $<.2$ & -- & 9.6 & +8.7 & 20.4 & +1.0 \\
\hline 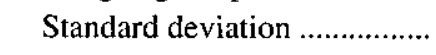 &.- & -- & - & -- & -- & -- & -- & -- & .7 & -- \\
\hline 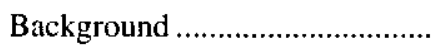 & .07 & +8.1 & .03 & -- & $<.2$ & -- & .10 & -- & 18.1 & +.8 \\
\hline Standard deviation ....................... & -- & -- & -- & - & -- & -- & -- & -- & .7 & -. \\
\hline
\end{tabular}

${ }^{1}$ Data provided by Global Geochemistry Corporation (written commun., Canoga Park, California, 1992).

used. Denitrification of $2.6 \mathrm{mg} / \mathrm{L}$ as $\mathrm{N}$ of nitrate would result in only a small change, $+0.7 \%$, in the $\delta^{15} \mathrm{~N}$ of the remaining nitrate-nitrogen. The $\delta^{15} \mathrm{~N}$ ratio of the produced $2.6 \mathrm{mg} / \mathrm{L}$ dinitrogen would be $+0.4 \%$. This would change the $\delta^{15} \mathrm{~N}$ of the total dissolved dinitrogen by $-0.05 \%$, assuming an initial dinitrogen concentration of $18.6 \mathrm{mg} / \mathrm{L}$ as $\mathrm{N}$ and initial $\delta^{15} \mathrm{~N}$ ratio equal to $+0.8 \%$ (Letolle, 1980). These changes are too small to be distinguished in the measured $\delta^{15} \mathrm{~N}$ ratios (table 11 ), given the variability in stable-isotopic ratios in effluent. However, the measured values are consistent with low rates of denitrifying activity.

\section{Mass Estimate of Denitrification}

Aquifer-sediment incubations, concentrations of dinitrogen, nitrous oxide and dissolved inorganic carbon, and nitrogen stable-isotope ratios were consistent with a low level of denitrification in the plume. The denitrification rates measured in core incubation were slightly higher than the rates determined from dinitrogen data. The core incubations may have overestimated in situ rates because aquifer sediment is slightly disturbed during sampling. Brooks and others (1994) reported that core incubations overestimated in situ rates in a sewage plume elsewhere on Cape Cod, where in situ rates were measured with an acetylene-block tracer test. Rates determined in the present study from cores and dinitrogen concentrations are low compared with denitrification rates measured in more organic-rich saturated sediments (Trudell and others, 1986; Slater and Capone, 1987; Bengtsson and Annadotter, 1989). However, they are comparable to the in situ rates measured by Brooks and others (1994) under low-organiccarbon conditions.

Denitrification rates determined from dinitrogen production probably are most appropriate for mass estimates of in situ denitrification. Denitrification rates determined from core incubations provide discrete measurements in time and space. Core-incubation rates must be extrapolated to an aquifer volume $10^{8}$ times larger than the incubation volume and a time period of many months to generate a mass estimate of denitrification occurring during the study period. In contrast, methods based on dinitrogen concentrations measure 
denitrification at spatial and temporal scales similar to the scale of plume movement. Denitrification rates from dinitrogen production integrate the effects of the varying geochemical conditions encountered by ground water along a flow path. The rates and mass estimates from dinitrogen methods, however, also are limited by the precision of aquifer and ground-water-flow characteristics, of the assumed source concentrations of dinitrogen, and of the dinitrogen sampling and analytical techniques.

The mean denitrification rate calculated from dinitrogen production, $3.0\left(\mathrm{ng}-\mathrm{N} / \mathrm{cm}^{3}\right) / \mathrm{d}$, corresponds to a nitrate reduction of $0.015 \mathrm{mg} / \mathrm{L}$ as $\mathrm{N}$ per foot of travel distance, using the ground-water-flow velocity of 0.5 $\mathrm{ft} / \mathrm{d}$ and aquifer characteristics as in previous calculations. This is equivalent to an attenuation in nitrate concentration of about $1.5 \mathrm{mg} / \mathrm{L}$ as $\mathrm{N}$ per $100 \mathrm{ft}$ of travel distance under anoxic conditions. This quantity is less than 5 percent of the nitrate concentrations in the center of the plume. Attenuation by this quantity could not be distinguished in nitrate concentrations or masses, given the variation in nitrogen concentrations in effluent and horizontal extent of anoxic zone during the study.

Mass estimates of denitrification in the plume were made in two ways. First, the mean rate from dinitrogen production, $3.0\left(\mathrm{ng}-\mathrm{N} / \mathrm{cm}^{3}\right) / \mathrm{d}$, was extrapolated to the time-varying volume of the anoxic zone. The volume of the anoxic zone was calculated for each of the five synoptic samplings using the triangular integration described previously. The volume was assumed to increase step-wise between samplings. The quantity thus estimated was $77 \mathrm{~kg}$ as $\mathrm{N}$, or about 2 to 3 percent of the total mass of nitrogen recharged to the aquifer during the study or in the septage-effluent plume in December 1992. This value is likely an overestimate, however, because dinitrogen concentrations were not elevated at all sites in the anoxic zone (fig. 32). The second mass estimate of denitrification was based on dinitrogen concentrations throughout the septageeffluent plume. Integrating dinitrogen concentrations exceeding the mean background concentration or atmospheric-equilibrium concentration yielded mass estimates of 46 and $51 \mathrm{~kg}$ as $\mathrm{N}$ of denitrification, respectively. These values are about 2 percent or less than the input nitrogen mass or nitrogen mass in the plume.

The low denitrification rates and the stimulation of rates with carbon addition suggest that denitrification in the septage-effluent plume was carbon limited.
Concentrations of dissolved organic carbon in the ground water (less than or equal to $2.5 \mathrm{mg} / \mathrm{L}$ ) could have supported a maximum nitrate reduction of about $2.5 \mathrm{mg} / \mathrm{L}$ as $\mathrm{N}$, based on stoichiometric relations where dissolved organic carbon is characterized as $\mathrm{CH}_{2} \mathrm{O}$ (eq. 12). Moreover, all this organic carbon was not likely to be readily degradable. Solid-phase organic carbon also might be used by denitrifying organisms. Solid-phase carbon concentrations in plume and uncontaminated sediments ranged from less than 0.01 to 1.5 $\mathrm{mg} / \mathrm{g}$, with a median of $0.1 \mathrm{mg} / \mathrm{g}(\mathrm{n}=88)$. A solid-phase organic carbon concentration of $0.1 \mathrm{mg} / \mathrm{g}$ could reduce about $380 \mathrm{mg} / \mathrm{L}$ as $\mathrm{N}$ of nitrate, if all this were organic carbon that was physically and chemically available for degradation, using the aquifer characteristics previously assumed $^{3}$. However, the solid-phase organic carbon in the aquifer has been exposed to aerobic ground water probably since deposition, or thousands of years. Therefore, the organic carbon is unlikely to be readily degradable.

\section{Summary of Reactive Processes Involving Nitrogen and Nitrogen Budget}

Microbial and chemical transformation processes in the unsaturated zone and in the septage-effluent plume altered the initial speciation of nitrogen in effluent and affected its transport and fate (fig. 35). The mass of nitrogen (excluding dinitrogen) in effluent discharged during the period of study, February 1990 to December 1992, consisted of 9 percent particulate organic nitrogen, 12 percent dissolved organic nitrogen, 49 percent ammonium, 3.8 percent nitrite, and 25 percent nitrate. Eleven percent of the total mass discharged during this period was in transit in the unsaturated zone in December 1992, based on the traveltime in the unsaturated zone. The mass of nitrogen in ground water and aquifer sediments in the plume in December 1992 consisted of 1.7 percent dissolved organic nitrogen, 5.4 percent dissolved ammonium, 17 percent sorbed ammonium, 0.1 percent nitrite, 75 percent nitrate, 0.4 percent nitrous oxide, and 2 percent dinitrogen derived from denitrification. The total mass of nitrogen in the septage-effluent plume corresponds to 73 percent of the

\footnotetext{
${ }^{3}$ Some of this carbon may have been solid inorganic carbon, as calcite was found in trace quantities in less than half of the sediment samples analyzed mineralogically (L.J. Poppe and A.M. Moffett, U.S. Geological Survey, Woods Hole, Mass., written commun., December 1990).
} 


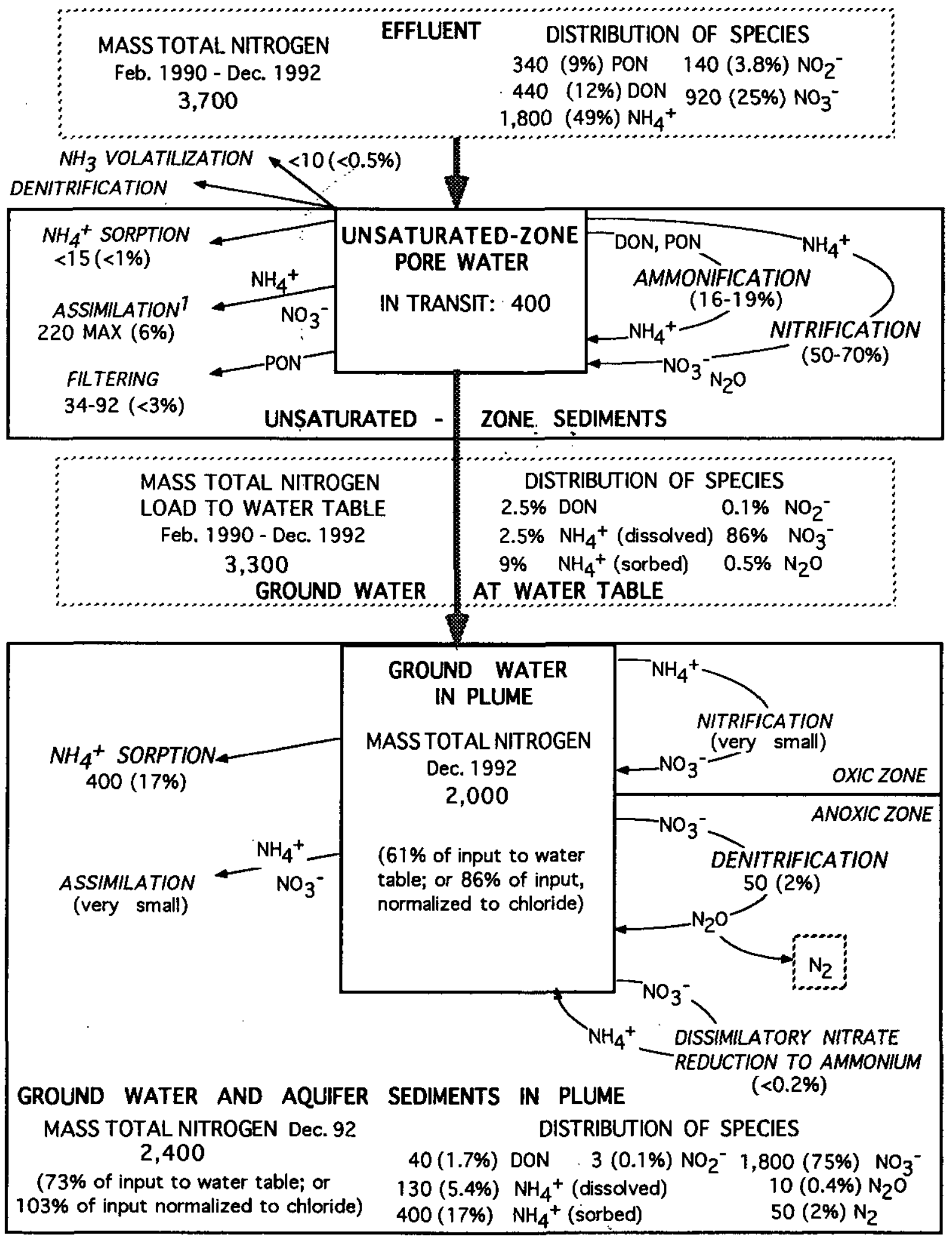

Figure 35. Nitrogen budget for the septage-effluent plume, February 1990 through December 1992. Masses in kilograms of nitrogen. Values in parentheses are percentage of total nitrogen in respective reservoir or associated with respective process during the study. PON, particulate organic nitrogen; DON, dissolved organic nitrogen; $\mathrm{NH}_{4}{ }^{+}$, ammonium; $\mathrm{NH}_{3}$, ammonia; $\mathrm{NO}_{2}{ }^{-}$, nitràte; $\mathrm{NO}_{3}{ }^{-}$, nitrate; $\mathrm{N}_{2} \mathrm{O}$, nitrous oxide; $\mathrm{N}_{2}$, dinitrogen from denitrification. 'Value includes aerobic processes in the saturated and unsaturated zones. 
mass discharged in the effluent (minus the mass in transit in the unsaturated zone). This value is similar to the percentage of the chloride in effluent in the plume by the same analysis ( 71 percent), indicating that all the effluent nitrogen could be accounted for.

\section{Unsaturated-Zone Processes}

The primary processes affecting nitrogen in the unsaturated zone were ammonification and nitrification (fig. 35). Ammonification transformed nearly all the dissolved organic nitrogen and most of the particulate organic nitrogen to ammonium, or 16 to 19 percent of total nitrogen in effluent. Through nitrification, a large fraction of the ammonium in effluent and of ammonium derived from organic nitrogen was oxidized to nitrate, or 50 to 70 percent of the total nitrogen in effluent. These values are based on the distribution of nitrogen species in effluent and ground water at the water table beneath the infiltration beds. Ammonification and nitrification resulted only in transformation among nitrogen species, not in any net attenuation of total nitrogen concentrations or load. Other unsaturated-zone processes that may have attenuated dissolved nitrogen were ammonium sorption, filtering of particulate organic nitrogen, ammonium and (or) nitrate assimilation, ammonia volatilization, and denitrification. The massbalance analyses suggested that these processes did not result in a large sustained loss of nitrogen from solution. The magnitude of several of these processes also can be estimated independently.

The mass of filtered particulate organic nitrogen can be evaluated from solid-phase nitrogen and carbon concentrations in infiltration-bed surface sediments. Suspended solids (particulate carbon and nitrogen) are almost entirely removed by soil-particle filtration in rapid-infiltration systems, primarily at or near the soil surface (Bouwer and others, 1980; Bouwer, 1985). Some of the filtered material is decomposed to soluble nitrogen- and carbon-containing compounds, while the remainder accumulates in the sediments. The median concentration of solid-phase nitrogen in infiltration-bed surface sediments for March through April 1992 was $0.6 \mathrm{mg} / \mathrm{g}(\mathrm{n}=20)$. This concentration, after correction for extractable ammonium, corresponds to a nitrogen mass of $25 \mathrm{~kg}$ as $\mathrm{N}$ in the surface sediments. The nitrogen mass estimated from the mean concentration of solid-phase carbon ${ }^{4}(4 \mathrm{mg} / \mathrm{g}, \mathrm{n}=20$ ) is $68 \mathrm{~kg}$ of nitrogen.
These masses are about 10 and 27 percent of the particulate organic nitrogen discharged in effluent through the time of sampling and are overestimates, because they include nitrogen immobilized through assimilation as well as filtering. Thus, much of the particulate organic nitrogen, although it may have been temporarily filtered out by sediments, was ultimately decomposed and transported in dissolved form to subsurface layers. Corresponding fractions of the particulate organic nitrogen discharged in effluent through December 1992 are less than 3 percent of the total nitrogen in effluent (fig. 35).

Nitrogen is assimilated during synthesis of microbial biomass (Schlesinger, 1991, p. 169), and can be evaluated from mass rates of aerobic respiration and nitrification. The mass of aerobic respiration occurring during the study can be approximated by the organiccarbon loss determined by mass-balance analysis (table 8). The corresponding nitrogen assimilation is $190 \mathrm{~kg}$ as $\mathrm{N}$, using a stoichiometric relation of $0.1 \mathrm{~g}$ nitrogen assimilated per gram carbon oxidized (Andrews, 1971). Nitrogen assimilated through nitrification, estimated above, is 20 to $30 \mathrm{~kg}$, using a stoichiometric relation of $0.01 \mathrm{~g}$ nitrogen assimilated per gram of ammoniumnitrogen nitrified (Fenchel and Blackburn, 1979). The maximum quantity of assimilation from heterotrophic growth and from nitrification, therefore, is about 6 percent of the total nitrogen in effluent and includes the small amount of saturated-zone assimilation by aerobic heterotrophs (see below) (fig. 35). However, this probably is a significant overestimation, because remineralization through microbial death and decay is not considered.

Ammonium sorption, ammonia volatilization and denitrification also represented minor sinks for dissolved nitrogen in the unsaturated zone (fig. 35). Ammonium sorption accounts for a permanent loss of nitrogen from solution of probably less than 1 percent, based on the infiltration-bed measurements discussed previously. Ammonia volatilization represents an even smaller loss. At the $\mathrm{pH}$ and temperature conditions of the effluent (median $\mathrm{pH}=7.2$, mean annual air temperature $=10^{\circ} \mathrm{C}$ ), ammonia makes up only 0.5 percent of the

\footnotetext{
${ }^{4}$ Mass of nitrogen estimated from carbon concentration using particulate carbon-to-nitrogen ratio in effluent of 4 to 1 , based on 15 effluent samples collected from March through December 1992, after correcting carbon concentration for background.
} 
total ammonium plus ammonia (Bowie and others, 1985 , p. 264). Volatilization of the 100 percent of the ammonia in effluent and produced in ammonification would be a loss of less than 0.5 percent of the total nitrogen in effluent. In fact, the actual fraction volatilized would be less than 100 percent. Finally, losses through denitrification may have occurred in anaerobic microsites in the unsaturated zone. However, the method by which effluent was discharged (short flooding and drying cycles) was unlikely to result in widespread anoxia in the unsaturated zone (Lance and Whisler, 1972; Bouwer, 1985; Ronen and others, 1987), which is necessary for denitrification.

\section{Saturated-Zone Processes}

The primary process affecting nitrogen in the saturated zone was ammonium sorption. Ammonium sorption occurred in the anoxic central zone of the plume, where ammonium concentrations were relatively high (fig. 19) and nitrification was restricted. Sorbed ammonium in aquifer sediments was about 17 percent of the total mass of nitrogen in the plume in December 1992. However, the sorbed-ammonium pool could change with changing concentrations of dissolved ammonium, other ions, or dissolved oxygen. If ammonium concentrations reaching the water table were to increase or concentrations of other ions were to decrease, the mass of sorbed ammonium-nitrogen would increase. Conversely, ammonium would be desorbed if dissolvedammonium concentrations decreased, if concentrations of other ions increased, or if dissolved-oxygen concentrations increased so that nitrification occurred.

Nitrification, nitrogen assimilation, denitrification, and dissimilatory nitrate reduction to ammonium also may have occurred in the saturated zone. Nitrification occurred mostly in the unsaturated zone, as indicated by the nitrogen-species distribution at the water table and in the plume as a whole (fig. 35). Relations among dissolved-ammonium, chloride, and dissolved-oxygen concentrations in the plume suggest that nitrification also occurred in the saturated zone (fig. 36). Ammonium concentrations were not linearly related to chloride concentrations in the saturated zone, as would be expected from conservative transport. At chloride concentrations less than $500 \mathrm{mg} / \mathrm{L}$ such as occurred in the oxygenated leading and lateral edges of the plume, ammonium concentrations were near $0 \mathrm{mg} / \mathrm{L}$ (fig. 36A). Ammonium concentrations were high (greater than
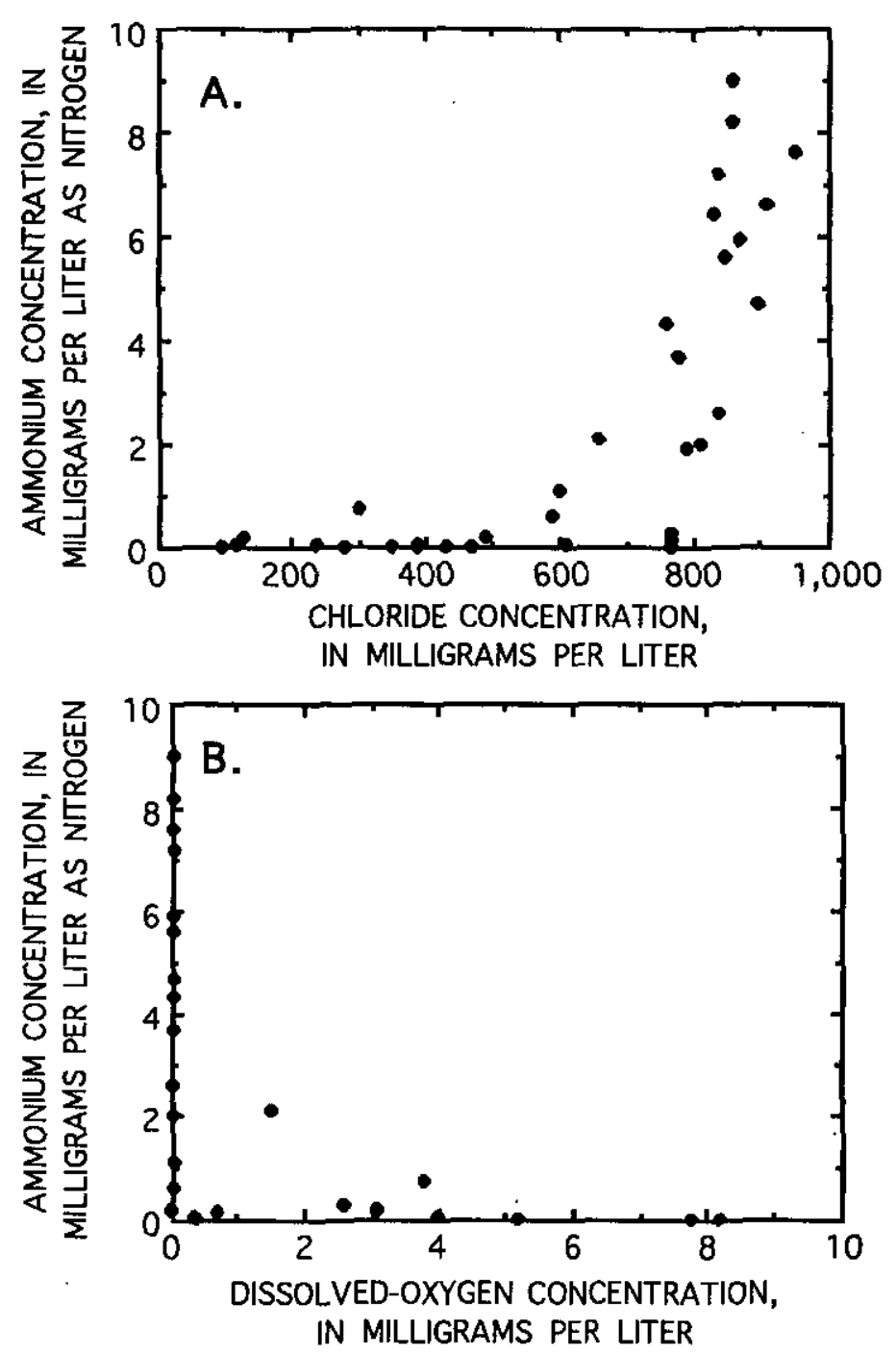

Figure 36. Relations of dissolved ammonium concentrations with chloride and dissolvedoxygen concentrations in the septage-effluent plume, December 1992. A. Ammonium with chloride, B. Ammonium with dissolved oxygen.

$1 \mathrm{mg} / \mathrm{L}$ as $\mathrm{N}$ ) only where dissolved-oxygen concentrations were less than $1 \mathrm{mg} / \mathrm{L}$ (fig. $36 B$ ). Saturated-zone nitrification depleted dissolved ammonium in the oxygenated areas of the plume but not in the anoxic zone, because nitrification is greatly reduced at dissolved-oxygen concentrations less than $1 \mathrm{mg} / \mathrm{L}$.

Microbial nitrogen assimilation did not greatly alter nitrogen masses in the plume. Nearly all the assimilation associated with aerobic respiration, estimated previously for unsaturated and saturated zones, occurred in the unsaturated zone. This is shown by comparing organic carbon attenuation in the unsaturated 
zone (91 percent of concentrations in effluent) with the total loss of organic carbon indicated by the mass balance ( 92 to 95 percent of carbon in effluent, normalized to chloride, table 9). The small fraction (1 to 4 percent) of the assimilated nitrogen from aerobic respiration occurring in the saturated zone corresponded to 0.3 to 0.5 percent of the total nitrogen in effluent. Assimilation associated with nitrification in the saturated zone also is likely very small. Little nitrification occurred in the saturated zone and the quantity of nitrogen assimilated per ammonium molecule oxidized is very low (see above).

Denitrification did not greatly affect nitrate transport during the study period. The mass of denitrification, estimated previously, is about 2 percent or less of the total nitrogen recharged to the aquifer or in the septage-effluent plume. Dissimilatory nitrate reduction to ammonium, which like denitrification is an anaerobic heterotrophic process (Chapelle, 1993, p. 89), is unlikely to have occurred to any significant extent in the plume. The partitioning between the two processes varies with the carbon-to-nitrogen ratio. Under highnitrate and low-carbon conditions, less than 10 percent of the total nitrate reduction goes to ammonium (Tiedje and others, 1982). In addition, nitrate reduction to ammonium is not favored under the mildly reducing conditions found in the plume (Buresh and Patrick, 1981; deCatanzaro and others, 1987; Jorgensen, 1989). Dissimilatory nitrate reduction to ammonium did not occur in a low-organic-carbon, high-nitrate sewage plume elsewhere on Cape Cod (Smith and Duff, 1988). The ratio of dissolved carbon to nitrate-nitrogen in the septage-effluent plume of the present study, 1:20, was very low. Thus, dissimilatory nitrate reduction to ammonium was unlikely to be a significant process. At 10 percent of the denitrification mass estimate, dissimilatory nitrate reduction would amount to less than 0.2 percent of the total nitrogen in the effluent or septageeffluent plume.

In summary, the nitrogen discharged in effluent during the study was affected by microbial processes in the unsaturated zone, which altered its species distribution but did not substantially attenuate the nitrogen input to the saturated zone. Ammonium sorption in the saturated zone represented a loss from solution of about 17 percent by December 1992. This pool of sorbed ammonium is likely to increase or decrease in size with changes in unsaturated-zone conditions or processes altering the quantity and (or) speciation of nitrogen reaching the water table. The remaining nitrogen in the saturated zone was primarily in the form of nitrate and underwent very little reaction during transport. Denitrification was occurring in the anoxic central region of the plume but at rates that were too low to significantly affect the nitrogen-species distribution or mass of nitrogen in the plume during the study.

\section{SUMMARY}

A nitrogen-rich plume of septage effluent-contaminated ground water resulting from infiltration of treated wastewater at the Tri-Town Septage-Treatment Facility was monitored from the beginning of effluent discharge in February 1990 through December 1992. The effluent was discharged at the Tri-Town Septage-Treatment Facility to a sandy glacial aquifer. Ambient ground water in the aquifer contained low concentrations of dissolved solids and was slightly acidic; sodium and chloride were the dominant ions (median concentrations 15 and $21 \mathrm{mg} / \mathrm{L}$, respectively). The aquifer is heterogeneous but can be divided into four lithologic units: (1) an upper fine-grained unit consisting of fine to very fine or fine to medium sand, with variable amounts of silt, 40 to $60 \mathrm{ft}$ thick; (2) an intermediate coarse-grained unit consisting of medium to very coarse sand, locally with some gravel, 5 to $60 \mathrm{ft}$ thick; (3) a lower fine-grained unit of interbedded fine to very fine and medium to fine sand with silt, 35 to $60 \mathrm{ft}$ thick; and (4) a lower coarsegrained unit of medium to coarse sand of undetermined thickness. The intermediate coarse-grained unit was much more permeable than the overlying and underlying fine-grained units; its hydraulic conductivity was more than an order of magnitude greater than that of the fine-grained units. The general direction of groundwater flow is westward and northwestward from the interior of Cape Cod toward the regional discharge areas at an adjacent coastal marsh and Cape Cod Bay. Steep vertical gradients in the study area were caused by lithologic heterogeneity and proximity of the site to the regional discharge area.

The volume and chemical quality of the treatmentfacility effluent was monitored throughout the study period. Daily discharge averaged $19,000 \mathrm{gal} / \mathrm{d}$ and varied seasonally, with means of 25,100 and 11,500 $\mathrm{gal} / \mathrm{d}$ during the summer and winter months, respectively. The major chemical constituents of the effluent were chloride (median $950 \mathrm{mg} / \mathrm{L}$ ), calcium (median 440 $\mathrm{mg} / \mathrm{L}$ ), and sodium (median $100 \mathrm{mg} / \mathrm{L}$ ). Nitrogen, 
potassium, organic carbon, sulfate, phosphorus, and boron were minor constituents. Nitrogen in the effluent was primarily in the form of ammonium (median 27 $\mathrm{mg} / \mathrm{L}$ as $\mathrm{N}$ ) and nitrate (median $11 \mathrm{mg} / \mathrm{L}$ as $\mathrm{N}$ ), with lesser amounts of dissolved organic nitrogen (median $4.0 \mathrm{mg} / \mathrm{L}$ as $\mathrm{N}$ ), particulate organic nitrogen (median 3.1 $\mathrm{mg} / \mathrm{L}$ as $\mathrm{N}$ ), and nitrite (median $0.8 \mathrm{mg} / \mathrm{L}$ as $\mathrm{N}$ ).

Chemical and microbial processes in the 40 -footthick unsaturated zone substantially changed the quality of the effluent. Concentrations of total dissolved nitrogen underwent little attenuation, but the distribution of nitrogen species was altered. Nearly all the dissolved organic nitrogen was mineralized to ammonium and most of the ammonium was nitrified to nitrate. Nitrification also resulted in a $\mathrm{pH}$ decrease from about 7.0 in the effluent to 5.0 in ground water. Cation exchange resulted in a 10-percent decrease in calcium concentration that was balanced by a nearly equivalent gain in magnesium. Concentrations of potassium, sulfate, and boron also were attenuated by exchange and(or) sorption reactions. The magnitude of the exchange and sorption processes decreased with time; the reactions were approaching steady state after 34 months of discharge. Concentrations of dissolved organic carbon and possibly the alkalinity in effluent were reduced through aerobic respiration. Nearly all the phosphorus in the effluent also was removed, probably through sorption and (or) precipitation reactions with aquifer sediments.

The physical development of the septage-effluent plume was affected by the lithologic heterogeneity, the three-dimensional flow system, and possibly density differences. By December 1992, the leading edge of the plume had traveled about $200 \mathrm{ft}$ westward and 450 northwestward from the infiltration beds. It initially split into two lobes as a result of the irregular geometry of the coarse- and fine-grained lithologic units. The plume also expanded radially so that it extended at least 100 to $130 \mathrm{ft}$ east and south of the infiltration beds. Vertically, the septage-effluent plume occurred in the upper fine-grained and intermediate coarse-grained units near the infiltrations beds. It preferentially flowed through the coarse-grained sediments and farther downgradient it was confined primarily to the intermediate coarsegrained unit. The mean linear velocity of the plume, calculated from breakthrough curves of chloride, was 0.4 to $0.5 \mathrm{ft} / \mathrm{d}$.
The distribution of chemical constituents in the plume resulted from advection, dispersion, and reactions. Chloride, which is transported conservatively in ground water, was used to quantify advective and dispersive transport. Chloride concentrations ranged from concentrations in effluent in the center of the plume (about $900 \mathrm{mg} / \mathrm{L}$ ) to less than $200 \mathrm{mg} / \mathrm{L}$ near the leading and lateral edges of the plume, where concentrations were reduced through mixing with ambient ground water. Concentrations of total dissolved nitrogen ranged from more than $40 \mathrm{mg} / \mathrm{L}$ as $\mathrm{N}$ in the center of the plume to less than $10 \mathrm{mg} / \mathrm{L}$ as $\mathrm{N}$ near the boundaries of the plume. Nitrate was the primary form of nitrogen in the septage-effluent plume. The plume developed an anoxic core, in which dissolved-oxygen concentrations were less than $0.05 \mathrm{mg} / \mathrm{L}$. The anoxic zone expanded with time at a rate that was comparable to the mean linear velocity of the ground water and was characterized by sharp horizontal and vertical boundaries. Advection and dispersion seemed to be the primary controls on the distribution of dissolved-oxygen concentrations in the saturated zone, although oxygen consumption at the boundaries of the anoxic zone also was likely.

Mass-balance analyses of constituents in the septage-effluent plume were made using a threedimensional triangular-integration method to calculate solute masses in the plume. Masses were estimated for five times during the study. Dissolved masses of chloride ranged from 46 to 73 percent of the effluent-input masses. The higher percentages were obtained through improved definition of areas of high concentrations and thicknesses in the later synoptic samplings. The masses of other constituents were normalized to recovered masses of chloride to identify reactive transport. The mass of total dissolved nitrogen in the plume ranged from 31 to 64 percent of the total (dissolved plus particulate) nitrogen in the effluent. These values, when normalized to the recovered masses of chloride, are equivalent to 62 to 90 percent of the total nitrogen in the effluent. Batch tests were used to derive mass estimates of sorbed ammonium from dissolved concentrations in the plume. A Langmuir isotherm provided the best fit to batch-test data, and ammonium sorption strongly depended on the ionic strength of the aqueous phase. The applicability of the batch-test sorption model to field conditions was tested by comparing sorbed and dissolved ammonium concentrations predicted with the model with measured concentrations in plume sediments. Mass estimates of sorbed ammonium in the 
plume were about three times the dissolved masses. The resulting total (sorbed plus dissolved) nitrogen masses in the plume ranged from 34 to 73 percent of the effluent-input masses. When normalized to recovered masses of chloride, the total nitrogen masses were within 5 percent of the effluent-input masses for the three later synoptic samplings. Calcium-magnesium exchange, boron attenuation, and sodium desorption also were suggested by the mass-balance analyses.

Measurements of denitrification in the septageeffluent plume with aquifer-sediment incubations and dinitrogen concentrations demonstrated that denitrification was occurring in the plume but at a very low rate. Nitrogen stable-isotope ratios and concentrations of dissolved inorganic carbon, an end product of denitrification, were inconclusive but did not contradict other measures. The mean rate measured with aquifer-core incubations from the anoxic zone was $9.6\left(\mathrm{ng}-\mathrm{N} / \mathrm{cm}^{3}\right) / \mathrm{d}$. The mean rate from dinitrogen production in the plume was $3.0\left(\mathrm{ng}-\mathrm{N} / \mathrm{cm}^{3}\right) / \mathrm{d}$. Aquifer-slurry incubations greatly overestimated the in situ rate but demonstrated that denitrification in the plume was carbon limited. The rate from dinitrogen data provided the best estimate of in situ rates, and corresponds to $1.5 \mathrm{mg} / \mathrm{L}$ as $\mathrm{N}$ of nitrate attenuation per $100 \mathrm{ft}$ of travel distance under anoxic conditions. Because of the short distances traveled by ground water in the anoxic zone during the study and variability of nitrogen concentrations in effluent, significant attenuation of nitrate concentrations was not observed in the field.

A nitrogen budget was constructed for the septageeffluent plume during the study period. In the unsaturated zone, large fractions of the total nitrogen in effluent were transformed by ammonification (16 to 19 percent) and nitrification (50 to 70 percent). This nitrification also produced dissolved concentrations of nitrous oxide as high as $0.4 \mathrm{mg} / \mathrm{L}$ as $\mathrm{N}$. Ammonification and nitrification did not result in any net attenuation of total nitrogen concentrations or load. Assimilation, filtering, and ammonium sorption also may have occurred in the unsaturated zone but did not result in any large sustained loss of nitrogen from solution. Ammonium sorption was the primary process affecting nitrogen transport in the saturated zone. Sorbed ammonium was about 17 percent of the total mass of plume nitrogen in December 1992. This sorbed-ammonium pool could increase or decrease with future changes in the concentrations of dissolved ammonium, other ions, or dis- solved oxygen. Denitrification had transformed about 2 percent of the total mass of nitrogen by the end of the study period. This quantity may increase as the plume travels farther downgradient from the treatment facility and the residence time of anoxic ground water increases. However, denitrification is unlikely to result in substantial attenuation of nitrogen concentrations in ground water until the plume has traveled several thousand feet or encounters more organic-rich sediments.

\section{REFERENCES CITED}

Andrews, J.F., 1971, Kinetic models of biological waste treatment processes: Biotechnology and Bioengineering, Symposium No. 2, p. 5-33.

Aravana, R., Evans, M.L., and Cherry, J.A., 1993, Stable isotopes of oxygen and nitrogen in source identification of nitrate from septic systems: Ground Water, v. 31, no. 2, p. $180-186$.

Balderston, W.L., Sherr, B., and Payne, W.J., 1975, Blockage by acetylene of nitrous oxide reduction in Pseudomonas perfectomarinus: Applied and Environmental Microbiology, v. 31, p. 504-508.

Barber II, L.B., 1990, Geochemical heterogeneity in a glacial outwash aquifer: effect of particle size and mineralogy on sorption on nonionic organic solutes: Boulder, Colorado, University of Colorado, unpublished Ph.D. thesis, $238 \mathrm{p}$.

Barlow, P.M., 1987, The use of temperature as a ground-water tracer in glacial outwash: Tucson, Arizona, University of Arizona, unpublished M.S. thesis, $141 \mathrm{p}$.

1994, Particle-tracking analysis of contributing areas of public-supply wells in simple and complex flow systems, Cape Cod, Massachusetts: U.S. Geological Survey Open-File Report 93-159, 68 p.

Barlow, P.M., and Hess, K.M., 1993, Simulated hydrologic responses of the Quashnet River stream-aquifer system to proposed ground-water withdrawals, Cape Cod, Massachusetts: U.S. Geological Survey Water-Resources Investigations Report 93-4064, $52 \mathrm{p}$.

Beauchamp, E.G., Trevors, J.T., and Paul, J.W., 1989, Carbon sources for denitrification: Advances in Soil Science, v. 10, p. 113-142.

Bengtsson, G., and Annadotter, H., 1989, Nitrate reduction in a groundwater microcosm determined by ${ }^{15} \mathrm{~N}$ gas chromatography-mass spectrometry: Applied and Environmental Microbiology, v. 55, p. 2861-2870.

Blackmer, A.M., and Bremner, J.M, 1978, Inhibitory effect of nitrate on reduction of $\mathrm{N}_{2} \mathrm{O}$ to $\mathrm{N}_{2}$ by soil microorganisms: Soil Biology and Biochemistry, v. 10, p. 187-191. 
Blackmer, A.M., Bremner, J.M., and Schmidt, E.L., 1980, Production of nitrous oxide by ammonia-oxidizing chemoautotrophic microorganisms in soil: Applied and Environmental Microbiology, v. 40, no. 12, p. 10601066.

Borden, R.C., and Bedient, P.B., 1986, Transport of dissolved hydrocarbons influenced by oxygen-limited biodegradation, 1. Theoretical development: Water Resources Research, v. 22, no. 13, p. 1973-1986.

Böttcher, J., Strebel, O., Voerkelius, S., and Schmidt, H.L., 1990 , Using isotope fractionation of nitrate-nitrogen and nitrate-oxygen for evaluation of microbial denitrification in a sandy aquifer: Journal of Hydrology, v. 114, p. 413424.

Bouwer, H., 1985, Renovation of wastewater with rapid-infiltration land treatment systems, in Asano, T., ed., Artificial recharge of groundwater: Boston, Mass., Butterworth Publishers, p. 249-282.

Bouwer, H., and Rice, R.C., 1976, A slug test for determining hydraulic conductivity of unconfined aquifers with completely or partially penetrating wells: Water Resources Research, v. 12 , no. 3, p. 423-428.

Bouwer, H., Rice, R.C., Lance, J.C., and Gilbert, R.G., 1980, Rapid-infiltration research at Flushing Meadows Project, Arizona: Joumal of the Water Pollution Control Fereration, v. 52 , p. $2457-2470$.

Bowie, G.L., Mills, W.B., Porcella, D.B., Campbell, C.L., Pagenkopf, J.R., Rupp, G.L., Johnson, K.M., Chan, P.W.H., Gherini, S.A., Chamberlin, C.E., and Barnwell, Jr., T.O., 1985, Rates, constants, and kinetics formulations in surface water quality modeling (2nd ed.): U.S. Environmental Protection Agency, Office of Research and Development, Environmental Research Laboratory, Athens, GA, EPA/600/3-85-040, 455 p.

Brooks, M.H., Smith, R.L., and Garabedian, S.P., 1994, Small-scale tracer tests applied to the measurement of in situ denitrification rates in a sewage-contaminated aquifer, Cape Cod, Massachusetts, in Morganwalp, D.W., and Aronson, D.A., eds., U.S. Geological Survey Toxic Substances Hydrology Program--Proceedings of the Technical Meeting, Colorado Springs, Colorado, September 2024, 1993: U.S. Geological Survey Water-Resources Investigations Report 94-4014, in press.

Buresh, R.J., and Patrick, W.H., Jr., 1981, Nitrate reduction to ammonium and organic nitrogen in an estuarine environment: Soil Biology and Biochemistry, v. 18, p. 279-283.

Burford, J.R., and Bremner, J.M., 1975, Relationships between the denitrification capacities of soils and total, water-soluble and readily decomposable soil organic matter: Soil Biology and Biochemistry, v. 7, p. 389-394.

Ceazan, M.L., Thurman, E.M, and Smith, R.L., 1989, Retardation of ammonium and potassium transport through a contaminated sand and gravel aquifer: the role of cation exchange: Environmental Science and Technology, v. 23, no. 11, p. 1402-1408.
Chapelle, F.H., 1993, Ground-water microbiology and geochemistry: New York, John Wiley and Sons, 424 p.

Crank, J., 1979, The mathematics of diffusion (2nd ed.): Oxford, England, Clarendon Press, 414 p.

Dance, J.T., and Reardon, E.J., 1983, Migration of contaminants in groundwater at landfill: A case study, 5. Cation migration in the dispersion test: Journal of Hydrology, v. 63, p. 109-130.

Davidson, E.A., Swank, W.T., and Perry, T.O., 1986, Distinguishing between nitrification and denitrification as sources of gaseous nitrogen production in soil: Applied and Environmental Microbiology, v. 52, no. 6, p. 12801286.

D'Elia, C.F., Studler, P.A., and Korwin, N., 1977, Determination of total nitrogen in aqueous solutions: Limnology and Oceanography, v. 22, p. 760-774.

deCatanzaro, J.B., Beauchamp, E.G., and Drury, C.F., 1987, Denitrification vs dissimilatory nitrate reduction in soil with alfalfa, straw, glucose, and sulfide treatments: Soil Biology and Biochemistry, v. 19, no. 5, p. 583-587.

Delwiche, C.C., and Steyn, P.L., 1970, Nitrogen isotope fractionation in soils and microbial reactions: Environmental Science and Technology, v. 4, no. 11, p. 929-935.

DeSimone, L.A., 1995, Development of a nitrogen-rich septage-effluent plume in a glacial aquifer, Cape Cod, Massachusetts: Boston, Massachusetts, Boston University, Ph.D. thesis, 302 p.

Drever, J.I., 1988, The geochemistry of natural waters (2nd ed.): Englewood Cliffs, N.J., Prentice-Hall, 437 p.

Fenchel, T., and Blackburn, T.H., 1979, Bacteria and mineral cycling: New York, Academic Press, 225 p.

Fetter, C.W., Jr., 1988, Applied hydrogeology (2nd ed.): New York, Macmillan Publishing Company, $592 \mathrm{p}$.

Firestone, M.K., Firestone, R.B., and Tiedje, J.M., 1980, Nitrous oxide from soil denitrification: factors controlling its biological production: Science, v. 208, p. 749751.

Fishman, M.J. and Friedman, L.C., eds., 1989, Methods for determination of inorganic substances in water and fluvial sediments: U.S. Geological Survey Techniques of Water-Resources Investigations, Chapter A1, Book 5, $545 \mathrm{p}$.

Focht, D.D., 1982, Denitrification, in Burns, R.G., and Slater, J.H., Experimental microbial ecology: Oxford, England, Blackwell Scientific Publications, p. 194-211.

Folk, R.L., 1974, Petrology of sedimentary rocks: Austin, Texas, Hemphill Publishing Company, $182 \mathrm{p}$.

Fontes, J.C., Andrews, J.N., Edmunds, W.M., Guerre, A., and Travi, Y., 1991, Paleorecharge by the Niger River (Mali) deduced from groundwater geochemistry: Water Resources Research, v. 27, no. 2, p. 199-214.

Francis, A.J., Slater, J.M., and Dodge, C.J., 1989, Denitrification in deep subsurface sediments: Geomicrobiology Journal, v. 7, no. 1, p. 103-116. 
Freeze, R.A., and Cherry, J.A., 1979, Groundwater: Englewood Cliffs, N.J., Prentice-Hall, 604 p.

Freyberg, D.L., 1986, A natural gradient experiment on solute transport in a sand aquifer, 2. Spatial moments and the advection and dispersion of nonreactive tracers: Water Resources Research, v. 22, no. 13, p. 2031-2046.

Frimpter, M.H. and Gay, F.B., 1979, Chemical quality of ground water on Cape Cod, Massachusetts: U.S. Geological Survey Water-Resources Investigations Report 79. $65,11 \mathrm{p}$.

Gamble, T.N., Betlach, M.R., and Tiedje, J.M., 1977, Numerically dominant denitrifying bacteria from world soils: Applied and Environmental Microbiology, v. 33, no. 4, p. 926-939.

Garabedian S.P., LeBlanc, D.R., Gelhar, L.W., and Celia, M.A., 1991, Large-scale natural gradient tracer test in sand and gravel, Cape Cod, Massachusetts, 2. Analysis of spatial moments for a nonreactive tracer: Water Resources Research, v. 27, no. 5, p. 911-924.

Guswa, J.H., and LeBlanc, D.R., 1985, Digital models of ground-water flow in the Cape Cod Aquifer System, Massachusetts: U.S. Geological Survey Water-Supply Paper 2209, 112 p.

Guy, H.P., 1969, Laboratory theory and methods for sediment analysis: U.S. Geological Survey Techniques of WaterResources Investigations, Chapter C1, Book 5, $58 \mathrm{p}$.

Harter, R.D., and Baker, D.E., 1977, Applications and misapplications of the Langmuir equation to soil adsorption phenomena: Soil Science Society of America Journal, v. 41 , p. $1077-1080$.

Hazen, A., 1893, Some physical properties of sands and gravels, with special reference to their use in filtration: Boston, Mass., Massachusetts State Board of Health, 24th annual report, p. 541-556.

Heaton, T.H.E., 1986, Isotopic studies of nitrogen pollution in the hydrosphere and atmosphere: a review: Chemical Geology, v. 59, p. 87-102.

Helsel, D.R., 1990, Less than obvious: statistical treatment of data below the reporting limit: Environmental Science and Technology, v. 24, no. 12, p. 1766-1774.

Helsel, D.R., and Cohn, T.A., 1988, Estimation of descriptive statistics for multiply censored water quality data: Water Resources Research, v. 24, no. 12, p. 1997-2004.

Hem, J.D., 1967, Equilibrium chemistry of iron in ground water, in Faust, S.D., and Hunter, J.V., eds., Principles and applications of water chemistry: New York, John Wiley, p. 625-643.

1972 , Chemical factors that influence the availability of iron and manganese in aqueous systems: Geological Society of America Bulletin, v. 83, no. 2, p. 443-450.

1985 , Study and interpretation of the chemical characteristics of natural water ( 3 rd ed.): U.S. Geological Survey Water-Supply Paper 2254, 263 p.
Hess, K.M., Wolf, S.H., and Celia, M.A., 1992, Large-scale natural gradient tracer test in sand and gravel, Cape Cod, Massachusetts, 3. Hydraulic conductivity variability and calculated macrodispersivities: Water Resources Research, v. 28, no. 8, p. 2011-2027.

Hillel, D., 1980, Fundamentals of Soil Physics: New York, Academic Press.

Hiscock, K.M, Lloyd, J.W., and Lerner, D.N., 1991, Review of natural and artificial denitrification of ground water: Water Research, v. 25, no. 9, p. 1099-1111.

Howes, B.L., Dacey, J.W.H., and Teal, J.M., 1985, Annual carbon mineralization and belowground production of Spartina alterniflora in a New England salt marsh: Ecology, v. 66, no. 2, p. 595-605.

Hunt, H.W., and Adamsen, F.J., 1985, Empirical representation of ammonium adsorption in two soils: Soil Science, v. 139 , no. 3, p. 205-210.

Idelovitch, E., and Michail, M., 1984, Soil-aquifer treatment-a new approach to an old method of wastewater reuse: Journal of the Water Pollution Control Federation, v. 56 , no. 8 , p. $936-943$.

Ingraham, J.L., 1981, Microbiology and genetics of denitrifiers, in Delwiche, C.C., ed., Denitrification, nitrification and atmospheric nitrous oxide: New York, John Wiley and Sons, p. 45-65.

Jorgensen, K.S., 1989, Annual pattern of denitrification and nitrate ammonification in estuarine sediment: Applied and Environmental Microbiology, v. 55, no. 7, p. 18411847.

Kaspar, H.F., 1982, Denitrification in marine sediment: measurement of capacity and estimate of in situ rate: Applied and Environmental Microbiology, v. 43, no. 3, p. 522527.

Keren, R., and Bingham, F.T., 1985, Boron in water, soils and plants; in Stewart, B.A., ed., Advances in Soil Science, v. 1, p. 229-276.

Kendall, C., and Grim, E., 1990, Combustion tube method for measurement of nitrogen isotope ratios using calcium oxide for total removal of carbon dioxide and water: Analytical Chemistry, v. 62, no. 5, p. 526-529.

Knowles, R., 1982, Denitrification: Microbiological Reviews, v. 46 , no. 1, p. 43-70.

Korom, S.F., 1992, Natural denitrification in the saturated zone-a review: Water Resources Research, v. 28 , no. 6 , p. 1657-1668.

Kreitler, C.W., 1979, Nitrogen-isotope ratio studies of soils and groundwater nitrate from alluvial fan aquifers in Texas: Journal of Hydrology, v. 42. p. 147-170.

Krumbein, W.C., and Monk, G.D., 1943, Permeability as a function of the size parameters of unconsolidated sand: Transactions of the American Institute of Mining and Metallurgical Engineers, v. 151, p. 153-163. 
Lalisse-Grundmann, G., Brunel, B., and Chalamet, A., 1988, Denitrification in a cultivated soil-optimal glucose and nitrate concentrations: Soil Biology and Biochemistry, v. 20 , no. 6 , p. $839-844$.

Lance, J.C., and Whisler, F.D., 1972, Nitrogen balance in soil columns intermittently flooded with secondary sewage effluent, Journal of Environmental Quality, v. 1, no. 2, p. $180-186$.

LeBlanc, D.R., 1984, Sewage plume in a sand and gravel aquifer, Cape Cod, Massachusetts: U.S. Geological Survey Water-Supply Paper $2218,28 \mathrm{p}$.

LeBlanc, D.R., and Celia, M.A., 1991, Density-induced downward movement of solutes during a natural-gradient tracer test, Cape Cod, Massachusetts, in Mallard, G.E., and Aronson, D.A., eds., U.S. Geological Survey Toxic Substances Hydrology Program--Proceedings of the technical meeting, Monterey, California, March 1115, 1991: U.S. Geological Survey Open-File Report 914034, p. 10-14.

LeBlanc, D.R., Garabedian, S.P., Quadri, R.D., Morin, R.H., Teasdale, W.E., and Paillet, F.L., 1988, Hydrogeologic controls on solute transport in a plume of sewage-contaminated ground water, in Ragone, S. E., ed., U.S. Geological Survey Program on Toxic Waste-Ground-water Contamination: Proceedings of the second technical meeting, Cape Cod, Massachusetts, October 21-25, 1985: U.S. Geological Survey Open-File Report 86-481, p. B7-B12.

LeBlanc, D.R., Garabedian, S.P., Hess, K.M., Gelhar, L.W., Quadri, R.D., Stollenwerk, K.G., and Wood, W.W., 1991, Large-scale natural gradient tracer test in sand and gravel, Cape Cod, Massachusetts, 1. Experimental design and observed tracer movement: Water Resources Research, v. 27, no. 5, p. 895-910.

LeBlanc, D.R., Guswa, J.H., Frimpter, M.H., and Londquist, C.J., 1986, Ground-water resources of Cape Cod, Massachusetts: U.S. Geological Survey Hydrologic Investigations Atlas HA-692, 4 sheets.

Letolle, R., 1980, Nitrogen-15 in the natural environment, in Fritz, P., and Fontes, J.C., eds., Handbook of environmental isotope geochemistry, Vol. 1, The terrestrial environment: New York, Elsevier, p. 407-433.

Manahan, S.E., 1984, Environmental chemistry (4th ed.): Boston, Mass., Willard Grant Press, 612 p.

Mariotti, A., Germon, J.C., Hubert, P., Kaiser, P., Letolle, R., Tardieux, A., and Tardieux, P., 1981, Experimental determination of nitrogen kinetic isotope fractionation-some principles; illustration for the denitrification and nitrification process: Plant and Soil, v. 62, p. 413-430.

Mariotti, A., Landreau, A., and Simon, B., 1988, ${ }^{15} \mathrm{~N}$ isotope biogeochemistry and natural denitrification process in groundwater-application to the chalk aquifer of northern France: Geochimica et Cosmochimica Acta, v. 52, no. 7, p. 1869-1878.
Marshall, T.J., and Holmes, J.W., 1979, Soil Physics: New York, Cambridge University Press, 345 p.

Masterson, J.M., and Barlow, P.M., 1994, Effects of simulated ground-water pumping and recharge on ground-water flow in the Cape Cod, Martha's Vineyard, and Nantucket Island Basins, Massachusetts: U.S. Geological Survey Open-File Report 94-316.

Matthess, G., 1982, The properties of ground water, translated by J.C. Harvey: New York, John Wiley, 406 p.

McBride, M.B., 1994, Environmental chemistry of soils: New York, Oxford University Press, $406 \mathrm{p}$.

McMasters, R.L., and Garrison, L.E., 1966, Mineralogy and origin of southern New England shelf sediments: Journal of Sedimentary Petrology, v. 36, p. 1131-1142.

McNabb, J.F., and Dunlap, W.J., 1975, Subsurface biological activity in relation to ground-water pollution: Ground Water, v. 13, no. 1, p. 33-43.

McNeill, J.D., 1986, Geonics EM39 borehole conductivity meter theory of operation: Mississauga, Ontario, Geonics Limited Technical Note TN-20, 17 p.

Millham, N.P., and Howes, B.L., 1995, A comparison of methods to determine $\mathrm{K}$ in a shallow coastal aquifer: Ground Water, v. 33, no. 1, p. 49-57.

Minagawa, M., Winter, D.A., and Kaplan, I.R., 1984, Comparison of Kjeldahl and combustion methods for measurement of nitrogen isotope ratios in organic matter: Analytical Chemistry, v. 56, p. 1859-1861.

Miyake, Y., and Wada, E., 1967, The abundance ratio of ${ }^{15} \mathrm{~N} /{ }^{14} \mathrm{~N}$ in marine environments: Rec. Oceanogr. Works Japan, v. 9, p. 37-53.

Morris, D.A., and Johnson, A.I., 1967, Summary of hydrologic and physical properties of rock and soil materials, as analyzed by the hydrologic laboratory of the U.S. Geological Survey 1948-1960: U.S. Geological Survey Water-Supply Paper 1839-D, 42 p.

Morris, J.T., Whiting, G.J., and Chapelle, F.H., 1988, Potential denitrification rates in deep sediments from the southeastern coastal plain: Environmental Science and Technology, v. 22, no. 7, p. 832-836.

Murray, R.E., Parsons, L.L., and Smith, M.S., 1989, Kinetics of nitrate utilization by mixed populations of denitrifying bacteria: Applied and Environmental Microbiology, v. 55 , no. 3 , p. $717-721$.

Myrold, D.D., and Tiedje, J.M., 1985, Diffusional constraints on denitrification in soil: Soil Science Society of America Journal, v. 49, p. 651-657.

Neter, J., Wasserman, W., and Kutner, M.H., 1985, Applied linear statistical models (2nd ed.): Homewood, Ill., Irwin Publishers, $1127 \mathrm{p}$.

Oldale, R.N., 1969a, Geologic map of the Harwich Quadrangle, Barnstable County, Cape Cod, Massachusetts: U.S. Geological Survey Map GQ-786. 
Oldale, R.N., 1969b, Seismic investigations on Cape Cod, Martha's Vineyard, and Nantucket, Massachusetts, and a topographic map of the basement surface from Cape Cod Bay to the islands, in Geological Survey Research 1969: U.S. Geological Survey Professional Paper 650-B, p. B122-B127.

1976, Notes on the generalized geologic map of Cape Cod: U.S. Geological Survey Open-File Report 76-765, $23 \mathrm{p}$.

1982, Pleistocene stratigraphy of Nantucket, Martha's Vineyard, the Elizabeth Islands, and Cape Cod, Massachusetts, in Larson, G.J. and Stone, B. D., eds., Late Wisconsinan glaciation of New England: Dubuque, Iowa, Kendall/Hunt, p. 1-34.

Oldale, R.N. and Barlow, R.A., 1986, Geologic map of Cape Cod and the islands, Massachusetts: U.S. Geological Survey Miscellaneous Investigation Series Map I-1763.

Oldale, R.N., Koteff, C., and Hartshorn, J.H., 1971, Geologic map of the Orleans Quandrangle, Barnstable County, Cape Cod, Massachusetts: U.S. Geological Survey Map GQ-931.

Oldale, R.N. and Tuttle, C.R., 1964, Seismic investigations on Cape Cod, Massachusetts: U.S. Geological Survey Professional Paper 475-D, p. D118-D122.

1965, Seismic investigations in the Harwich and Dennis Quadrangles, Cape Cod, Massachusetts, in Geological Survey Research 1965: U.S. Geological Survey Professional Paper 525-D, p. D101-D105.

Palmer, C.D., 1977, Hydrological implications of various wastewater management proposals for the Falmouth area of Cape Cod, Massachusetts: Woods Hole Oceanographic Institution Technical Report WHOI-77-32 (Appendix), $142 \mathrm{p}$.

Parkin, T.B., 1987, Soil microsites as a source of denitrification variability: Soil Science Society of America Journal, v. 51, p. 1194-1199.

Pedersen, J.K., Bjerg, P.L., and Christensen, T.H., 1991, Correlation of nitrate profiles with groundwater and sediment characteristics in a shallow sandy aquifer: Journal of Hydrology, v. 124, p. 263-277.

Perlmutter, N.M. and Liever, M., 1970, Dispersal of plating wastes and sewage contaminants in ground water and surface water, South Farmingdale-Massapequa area, Nassau County, New York: U.S. Geological Survey Water-Supply Paper 1879-G, $67 \mathrm{p}$.

Postma, D, and Brockenhuus-Schack, B.S., 1987, Diagenesis of iron in proglacial sand deposits of Late- and PostWeschselian age: Journal of Sedimentary Petrology, v. 57, no. 6, p. 1040-1053.

Reddy, K.R., Rao, P.S.C., and Jessup, R.E., 1982, The effect of carbon mineralization on denitrification kinetics in mineral and organic soils, Soil Science Society of America Journal, v. 46, p. 62-68.
Robertson, W.D., Cherry, J.A., and Sudicky, E.A., 1991, Ground-water contamination from two small septic systems on sand aquifers: Ground Water, v. 29 , no. 1, p. 8292.

Ronen, D., Magaritz, M., Almon, E., and Amiel, A.J., 1987a, Anthropogenic anoxification (eutrophication) of the water-table region of a deep phreatic aquifer: Water Resources Research, v. 23, no. 8, p. 1554-1560.

Ronen, D., Magaritz, M., Gvirtzman, H., and Garner, W., $1987 \mathrm{~b}$, Microscale chemical heterogeneity in groundwater: Journal of Hydrology, v. 92, p. 173-178.

Rudolph, D.L., Kachanoski, R.G., Celia, M.A., and LeBlanc, D.R., 1993, Flow and solute transport during infiltration experiments in unsaturated sand and gravel, Cape Cod, Massachusetts, in Morganwalp, D.W., and Aronson, D.A., eds., U.S. Geological Survey Toxic Substances Hydrology Program-Abstracts of the Technical Meeting, Colorado Springs, Colorado, September 20-24, 1993: U.S. Geological Survey Open-File Report 93-454, p. 18.

Ryan, B.F., Joiner, B.L., and Ryan, Jr., T.A., 1985, Minitab Handbook (2nd ed.): Boston, Mass., PWS-Kent Publishing Company, $385 \mathrm{p}$.

Ryden, J.C., Lund, L.J., and Focht, D.D., 1979, Direct measurement of denitrification loss from soils: I. Laboratory evaluation of acetylene inhibition of nitrous oxide reduction: Soil Science Society of America Journal, v. 43, p. 104-110.

SAS Institute Inc., 1988, SAS/ETS User's Guide, Version 6, First Edition: Cary, N.C., SAS Institute Inc., 560 p.

Scheiner, D., 1976, Determination of ammonia and Kjeldahl nitrogen by indophenol method: Water Research, v. 10, p. 31-36.

Schlesinger, W.H., 1991, Biogeochemistry: An analysis of global change: San Diego, Calif., Academic Press, $443 \mathrm{p}$.

Schincariol, R.A., and Schwartz, F.W., 1990, An experimental investigation of variable density flow and mixing in homogeneous and heterogeneous media: Water Resources Research, v. 26, no. 10, p. 2317-2329.

Shoemaker, H.E., McLean, E.O., and Pratt, P.F., 1961, Buffer methods for determining lime requirements of soils with appreciable amounts of extractable aluminum: Soil Science Society of America, Proceedings, v. 25, p. 274-277.

Slater, J.M., and Capone, D.G., 1987, Denitrification in aquifer soil and nearshore marine sediments influenced by groundwater nitrate: Applied and Environmental Microbiology, v. 53, no. 6, p. 1292-1297.

Smith, R.L, and Duff, J.H., 1988, Denitrification in a sand and gravel aquifer: Applied and Environmental Microbiology, v. 54, no. 5, p. 1071-1078.

Smith, R.L., Duff, J.H., and Howes, B.L., 1987, Development of techniques to measure in situ rates of microbial processes in a contaminated aquifer, in Franks, B.J., ed., 
U.S. Geological Survey Program on Toxic WasteGround-Water Contamination: Proceedings of the third technical meeting, Pensacola, Florida, March 23-27, 1987: U.S. Geological Survey Open-File Report 87-109, p. B25-B29.

Smith, R.L, Howes, B.L., and Duff, J.H., 1991, Denitrification in nitrate-contaminated groundwater: occurrence in steep vertical geochemical gradients: Geochimica et Cosmochimica Acta, v. 55, no. 7, p. 1815-1825.

Sposito, G., 1989, The chemistry of soils: Oxford, England, Oxford University Press, 277 p.

Starr, R.C., and Gillham, R.W., 1993, Denitrification and organic carbon availability in two aquifers: Ground Water, v. 31, no. 6, p. 934-947.

Stevens, J.H., 1994, Analysis and modeling of infiltration and solute transport experiments in unsaturated sand and gravel, Cape Cod, Massachusetts: Princeton University, unpublished M.S. thesis, $266 \mathrm{p}$.

Strahler, A.N., 1966, A geologist's view of Cape Cod: Garden City, N.Y., The Natural History Press, 115 p.

Tiedje, J.M., 1982, Denitrification, in Page, A.L., Miller, R.H., and Keeney, D. R., eds., Methods of soil analysis, Part 2, Chemical and microbiological properties (2nd ed.): Madison, Wis., Agronomy Monograph Number 9, American Society of Agronomy, Chapter 9, p. 1011-1025.

Tiedje, J.M., Sexstone, A.J., Myrold, D.D., and Robinson, J.A., 1982, Denitrification: ecological niches, competition and survival: Antonie van Leeuwenhoek, v. 48, p. 569-583.

Tiedje, J.M., Simkins, S., and Groffman, P.M., 1989, Perspectives on measurement of denitrification in the field including recommended protocols for acetylene based methods: Plant and Soil, v. 115, p. 261-284.

Tortuoso, A.C., and Hutchinson, G.L., 1990, Contributions of autotrophic and heterotrophic nitrifiers to soil NO and $\mathrm{N}_{2} \mathrm{O}$ emissions: Applied and Environmental Microbiology, v. 56, no. 6, p. 1799-1805.

Trudell, M.R., Gillham, R.W., and Cherry, J.A., 1986, An insitu study of the occurrence and rate of denitrification in a shallow unconfined sand aquifer: Journal of Hydrology, v. 83, p. 251-268.

Ueda, S., Ogura, N., and Yoshinari, T., 1993, Accumulation of nitrous oxide in aerobic groundwaters: Water Research, v. 27 , no. 12 , p. $1787-1792$.

Valocchi, A.J., 1985, Validity of the local equilibrium assumption for modeling sorbing solute transport through homogeneous soils: Water Resources Research, v. 21, no. 6, p. 808-820.

Valocchi, A.J., Street, R.L., and Roberts, P.V., 1981, Transport of ion-exchanging solutes in groundwater: Chromatographic theory and field simulation: Water Resoruces Research, v. 17, no. 5, p. 1517-1527.
Veith, J.A., and Sposito, G., 1977, On the use of the Langmuir equation in the interpretation of "adsorption" phenomena: Soil Science Society of America Journal, v. 41, p. 697-703.

Vogel, J.C., Talma, A.S., and Heaton, T.H.E., 1981, Gaseous nitrogen as evidence for denitrification in groundwater: Journal of Hydrology, v. 50., p. 191-200.

Walter, D.A., and Stollenwerk, K.G., 1994, The transport of phosphorus in a sand and gravel aquifer near Ashumet Pond, Cape Cod, Massachusetts, in Geological Society of America, Abstracts with Programs: 1994 Annual Meeting, p. A-199.

Weiskel, P.K., and Howes, B.L., 1992, Differential transport of sewage-derived nitrogen and phosphorus through a coastal watershed: Environmental Science and Technology, v. 26, no. 2, p. 352-360.

Wershaw, R.L., Fishman, M.J., Grabbe, R.R., and Lowe, L.E., eds, 1987, Methods for determination of organic substances in water and fluvial sediments: U.S. Geological Survey Techniques of Water-Resources Investigations, Chapter A3, Book 5, 80 p.

Wilson, G.B., Andrews, J.N., and Bath, A.H., 1990, Dissolved gas evidence for denitrification in the Lincolnshire Limestone groundwaters, Eastern England: Journal of Hydrology, v. 113, p. 51-60.

Wolf, S.H., 1988, Spatial variability of hydraulic conductivity in a sand and gravel aquifer: Massachusetts Institute of Technology, unpublished M.S. thesis, $118 \mathrm{p}$.

Wolf, S. H., Celia, M.A., and Hess, K.M., 1991, Evaluation of hydraulic conductivities calculated from multiport-permeameter measurements: Ground Water, v. 29, no. 4, p. 516-525.

Wood, W.W., and Signor, D.C., 1975, Geochemical factors affecting artificial recharge in the unsaturated zone, Transactions of the American Society of Agricultural Engineers, v. 18, p. 677-683.

Yeh, T.-C., Gelhar, L.W., and Gutjahr, A.L., 1985, Stochastic analysis of unsaturated flow in heterogeneous soils, 3 . Observations and applications: Water Resources Research, v. 21, no. 4, p. 465-471.

Yoshida, T., and Alexander, M., 1970, Nitrous oxide formation by Nitrosomonas europaea and heterotrophic microorganisms, Soil Science Society of America Proceedings, v. 34, p. 880-882.

Yoshinari, T., and Knowles, R., 1976, Acetylene inhibition of nitrous oxide reduction by denitrifying bacteria: Biochemistry and Biophysics Research Communications, v. 69 , p. 705-710.

Zapico, M.M., Vales, S., and Cherry, J.A., 1987, A wireline piston core barrel for sampling cohesionless sand and gravel below the water table: Ground Water Monitoring Review, v. 7, p. 74-82.

Zienkiewicz, O.C., 1977, The finite element method (3rd. ed.): New York, McGraw Hill. 
TABLE 12 
Table 12. Location of cluster sites and locations and screened intervals of wells

[Altitude of land surface and location of screened interval in feet above (+) or below (-) sea level. All wells installed by the USGS in the sequence indicated by the USGS well identifier, October 1988 to September 1992, unless otherwise noted. Wells consist of 2-inch inner diameter polyvinylchloride pipe, unless otherwise noted; slot size of well screens equal to $0.010 \mathrm{inch}]$

\begin{tabular}{|c|c|c|c|c|c|c|}
\hline \multirow{2}{*}{ Cluster site } & \multirow{2}{*}{$\begin{array}{c}\text { Latitude } \\
., "\end{array}$} & \multirow{2}{*}{$\begin{array}{l}\text { Longitude } \\
\text { - }\end{array}$} & \multirow{2}{*}{$\begin{array}{l}\text { Altitude of } \\
\text { land surface }\end{array}$} & \multirow{2}{*}{$\begin{array}{l}\text { USGS well } \\
\text { identifier }\end{array}$} & \multicolumn{2}{|c|}{ Screened interval } \\
\hline & & & & & Top & Bottom \\
\hline 25 & 414642 & $7000 \quad 10$ & 76.1 & OSW 25 & 0.0 & -1.5 \\
\hline \multirow[t]{4}{*}{86} & 414656 & 700023 & 59.8 & OSW 137 & +9.7 & -.3 \\
\hline & & & & OSW 84 & -16.0 & -17.0 \\
\hline & & & & OSW 85 & -37.6 & -38.6 \\
\hline & & & & OSW 86 & -68.2 & -69.2 \\
\hline \multirow[t]{4}{*}{87} & 414655 & 700024 & 53.4 & OSW 88 & -.7 & -1.7 \\
\hline & & & & OSW 89 & -42.5 & -43.5 \\
\hline & & & & OSW 163 & -31.1 & -36.1 \\
\hline & & & & OSW 87 & -81.6 & -82.6 \\
\hline \multirow[t]{6}{*}{93} & 414654 & 700023 & 56.5 & OSW 135 & +18.6 & +8.6 \\
\hline & & & & OSW 178 & +3.6 & -1.4 \\
\hline & & & & OSW 90 & -3.1 & -4.1 \\
\hline & & & & OSW 91 & -28.2 & -29.2 \\
\hline & & & & OSW 92 & -48.5 & -49.5 \\
\hline & & & & OSW 93 & -84.5 & -85.5 \\
\hline \multirow[t]{4}{*}{94} & 414653 & 700023 & 55.3 & OSW 108 & +6.1 & +1.1 \\
\hline & & & & OSW 95 & -25.0 & -26.0 \\
\hline & & & & OSW 166 & -47.4 & -52.4 \\
\hline & & & & OSW 94 & -73.6 & -74.6 \\
\hline \multirow[t]{5}{*}{96} & 414654 & 700024 & 46.9 & OSW 115 & +11.7 & +6.7 \\
\hline & & & & OSW 99 & -11.8 & -12.8 \\
\hline & & & & OSW 114 & $-26: 5$ & -27.5 \\
\hline & & & & OSW 98 & -47.8 & -48.8 \\
\hline & & & & OSW 96 & -91.1 & -92.1 \\
\hline \multirow[t]{2}{*}{100} & 414653 & 700024 & 41.0 & OSW 102 & -33.1 & -34.1 \\
\hline & & & & OSW 100 & -89.1 & -90.1 \\
\hline \multirow[t]{3}{*}{105} & 414655 & $\begin{array}{llll}70 & 00 & 18\end{array}$ & 65.5 & OSW 103 & +3.0 & -2.0 \\
\hline & & & & OSW 104 & -23.9 & -28.9 \\
\hline & & & & OSW 105 & -46.5 & -51.5 \\
\hline \multirow[t]{3}{*}{111} & 414654 & $\begin{array}{llll}70 & 00 & 27\end{array}$ & 22.4 & OSW 110 & +1.7 & -3.3 \\
\hline & & & & OSW 109 & -32.5 & -37.5 \\
\hline & & & & OSW 111 & -69.6 & -74.6 \\
\hline 112 & 414651 & 700028 & 22.1 & OSW 112 & +.6 & -4.4 \\
\hline 116 & 414649 & 700024 & 57.0 & OSW 116 & +10.3 & +5.3 \\
\hline 117 & 414640 & $\begin{array}{lll}70 & 00 & 18\end{array}$ & 52.1 & OSW 117 & +5.0 & 0.0 \\
\hline \multirow[t]{2}{*}{118} & $4146^{\prime} 42$ & $70 \quad 00^{\prime} 32$ & 12.4 & OSW 119 & +5.4 & +0.4 \\
\hline & & & & OSW 118 & -69.6 & -74.2 \\
\hline
\end{tabular}


Table 12. Location of cluster sites and locations and screened intervals of wells--Continued

\begin{tabular}{|c|c|c|c|c|c|c|}
\hline \multirow{2}{*}{ Cluster site } & \multirow{2}{*}{$\begin{array}{c}\text { Latitude } \\
0,1 "\end{array}$} & \multirow{2}{*}{ Longitude } & \multirow{2}{*}{$\begin{array}{l}\text { Altitude of } \\
\text { land surface }\end{array}$} & \multirow{2}{*}{$\begin{array}{l}\text { USGS well } \\
\text { identifier }\end{array}$} & \multicolumn{2}{|c|}{ Screened interval } \\
\hline & & & & & Top & Bottom \\
\hline \multirow[t]{2}{*}{120} & 414654 & 700014 & 76.1 & OSW 121 & +8.5 & +3.5 \\
\hline & & & & OSW 120 & -28.9 & -33.9 \\
\hline 122 & $\begin{array}{lll}41 & 47 & 10\end{array}$ & 700021 & 39.6 & OSW 122 & -2.3 & -7.3 \\
\hline 123 & $\begin{array}{lll}41 & 47 & 03\end{array}$ & 700020 & 40.9 & OSW 123 & +3.9 & -1.1 \\
\hline 124 & 414700 & 700024 & 44.8 & OSW 124 & +3.2 & -1.8 \\
\hline 125 & 414649 & 700025 & 46.6 & OSW 125 & +9.8 & +4.8 \\
\hline 126 & 414655 & $7000 \quad 18$ & 64.6 & ${ }^{1}$ OSW 126 & +17.6 & -2.4 \\
\hline 127 & 414653 & 700021 & 58.2 & ${ }^{1}$ OSW 127 & +21.2 & +1.2 \\
\hline 128 & 414653 & 700023 & 57.0 & ${ }^{1} \mathrm{OSW} 128$ & +20.0 & 0.0 \\
\hline 129 & 414654 & 700023 & 57.0 & ${ }^{1}$ OSW 129 & +20.0 & 0.0 \\
\hline \multirow[t]{2}{*}{131} & 414652 & $\begin{array}{llll}70 & 00 & 18\end{array}$ & 67.0 & ${ }^{2} \mathrm{OSW} 130$ & +17.0 & -3.0 \\
\hline & & & & ${ }^{2} \mathrm{OSW} 131$ & -1.0 & -21.0 \\
\hline 132 & 414657 & $\begin{array}{lll}70 & 00 & 27\end{array}$ & 45.8 & ${ }^{2} \mathrm{OSW} 132$ & +10.8 & -9.2 \\
\hline 133 & 414651 & $\begin{array}{lll}70 & 00 & 31\end{array}$ & 10.0 & ${ }^{2} \mathrm{OSW} 133$ & +10.0 & -10.0 \\
\hline 134 & 414655 & 700028 & 22.4 & ${ }^{2} \mathrm{OSW} 134$ & +13.4 & -6.6 \\
\hline \multirow[t]{2}{*}{144} & $41 \quad 4652$ & $70 \quad 0026$ & 39.2 & OSW 145 & +2.1 & -2.9 \\
\hline & & & & OSW 144 & -27.9 & -32.9 \\
\hline 146 & 414658 & 700026 & 48.6 & OSW 146 & +6.4 & +1.4 \\
\hline \multirow[t]{5}{*}{147} & 414655 & 700022 & 57.7 & OSW 141 & +17.6 & +7.6 \\
\hline & & & & OSW 142 & +4.6 & -0.4 \\
\hline & & & & OSW 165 & -4.9 & -9.9 \\
\hline & & & & OSW 152 & -12.9 & -17.9 \\
\hline & & & & OSW 147 & -23.9 & -28.9 \\
\hline \multirow[t]{2}{*}{148} & 414554 & $\begin{array}{lll}70 & 00 & 26\end{array}$ & 38.7 & OSW 143 & +1.5 & -3.5 \\
\hline & & & & OSW 148 & -68.3 & -73.3 \\
\hline \multirow[t]{2}{*}{149} & 414656 & $70 \quad 0021$ & 59.8 & OSW 107 & +10.5 & +5.5 \\
\hline & & & & OSW 149 & -12.2 & -17.2 \\
\hline \multirow[t]{3}{*}{150} & 414654 & $7000 \quad 23$ & 57.2 & OSW 136 & +20.3 & +10.3 \\
\hline & & & & OSW 160 & +12.7 & +7.7 \\
\hline & & & & OSW 150 & +6.7 & +1.7 \\
\hline \multirow[t]{3}{*}{151} & 414654 & $70 \quad 0020$ & 57.1 & OSW 153 & +12.6 & +7.6 \\
\hline & & & & OSW 157 & -25.6 & -30.6 \\
\hline & & & & OSW 151 & 52.0 & -57.0 \\
\hline
\end{tabular}


Table 12. Location of cluster sites and locations and screened intervals of wells--Continued

\begin{tabular}{|c|c|c|c|c|c|c|}
\hline \multirow{2}{*}{ Cluster site } & \multirow{2}{*}{$\begin{array}{c}\text { Latitude } \\
\circ, \|\end{array}$} & \multirow{2}{*}{$\begin{array}{c}\text { Longitude } \\
0,1\end{array}$} & \multirow{2}{*}{$\begin{array}{l}\text { Altitude of } \\
\text { land surface }\end{array}$} & \multirow{2}{*}{$\begin{array}{l}\text { USGS well } \\
\text { identifier }\end{array}$} & \multicolumn{2}{|c|}{ Screened interval } \\
\hline & & & & & Top & Bottom \\
\hline \multirow[t]{3}{*}{154} & 414656 & 700025 & 56.4 & OSW 138 & +10.6 & +.6 \\
\hline & & & & OSW 155 & -46.1 & -51.1 \\
\hline & & & & OSW 154 & -65.6 & -70.6 \\
\hline \multirow[t]{4}{*}{156} & 414658 & 700024 & 55.3 & OSW 140 & +6.9 & 3.1 \\
\hline & & & & OSW 167 & -12.8 & -17.8 \\
\hline & & & & OSW 161 & -23.6 & -28.6 \\
\hline & & & & OSW 156 & -45.7 & -50.7 \\
\hline 158 & 414656 & 700026 & 56.5 & OSW 158 & -54.5 & -59.5 \\
\hline 159 & 414657 & $7000 \quad 22$ & 56.8 & OSW 159 & +3.5 & -6.5 \\
\hline \multirow[t]{2}{*}{162} & 414657 & 700020 & 73.8 & OSW 164 & +0.4 & -4.6 \\
\hline & & & & OSW 162 & -45.2 & -50.2 \\
\hline \multirow[t]{3}{*}{168} & 414658 & 700022 & 50.9 & OSW 139 & +18.4 & +8.4 \\
\hline & & & & OSW 172 & +2.8 & -2.2 \\
\hline & & & & OSW 168 & -46.1 & -51.1 \\
\hline \multirow[t]{2}{*}{169} & 414655 & 700022 & 57.2 & OSW 170 & -12.8 & -17.8 \\
\hline & & & & OSW 169 & -31.8 & -36.8 \\
\hline \multirow[t]{2}{*}{171} & 414555 & 700026 & 47.0 & OSW 113 & +9.4 & +4.3 \\
\hline & & & & OSW 171 & -44.6 & -49.6 \\
\hline \multirow[t]{5}{*}{174} & 414653 & $7000 \quad 19$ & 55.9 & OSW 106 & +10.5 & +5.5 \\
\hline & & & & OSW 173 & +3.5 & -1.5 \\
\hline & & & & OSW 179 & -6.1 & -11.1 \\
\hline & & & & OSW 175 & -18.7 & -23.7 \\
\hline & & & & OSW 174 & -32.0 & -37.0 \\
\hline
\end{tabular}

